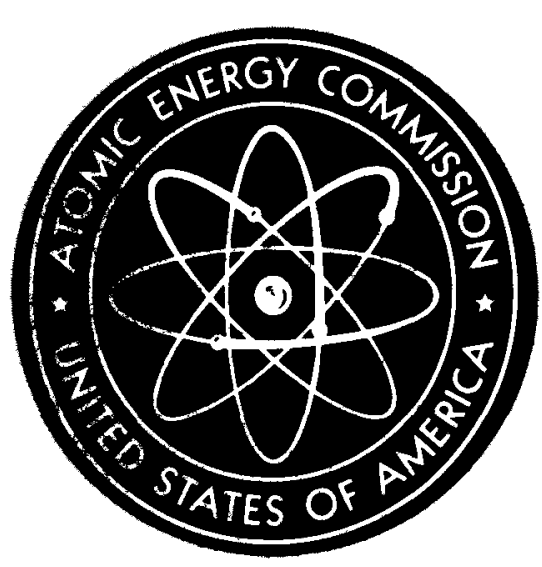

\title{
MASTER
}

NY0-10721

\section{RADIOISOTOPE SHIELDING DESIGN MANUAL}

Prepared by

William H. Steigelmann

July 1963
This document 18 PUBLICLY RELEASABLE Thenta/sices
Authorizng Oticial
Date: $3 / 3 / 10$

Laboratories for Research and Development

The Franklin Institute

Philadelphia, Penısylvania 


\section{DISCLAIMER}

This report was prepared as an account of work sponsored by an agency of the United States Government. Neither the United States Government nor any agency Thereof, nor any of their employees, makes any warranty, express or implied, or assumes any legal liability or responsibility for the accuracy, completeness, or usefulness of any information, apparatus, product, or process disclosed, or represents that its use would not infringe privately owned rights. Reference herein to any specific commercial product, process, or service by trade name, trademark, manufacturer, or otherwise does not necessarily constitute or imply its endorsement, recommendation, or favoring by the United States Government or any agency thereof. The views and opinions of authors expressed herein do not necessarily state or reflect those of the United States Government or any agency thereof. 


\section{DISCLAIMER}

Portions of this document may be illegible in electronic image products. Images are produced from the best available original document. 
Other issues of this report bear the number F-B1978.

\section{LEGAL NOTICE}

This report was prepared as an account of Government sponsored work. Neither the Untted States, nor the Commission, nor any person acting on behalf of the Commission:

A. Makes any warranty or representation, expressed or Implied, with respect to the accuracy, completeness, or usefulness of the information contained in this report, or that the use of any information, apparatus, method, or process disclosed in this report may not infringe privately owned rights; or

B. Assumes any liabilities with respect to the use of, or for damages resulting from the use of any information, apparatus, method, or process disclosed in this report.

As used in the above, "person acting on behalf of the Commission" includes any employee or contractor of the Commission, or employee of such contractor, to the extent that such employee or contractor of the Commission, or employee of such contractor prepares, disseminates, or provides access to, any information pursuant to his employment or contract with the Commission, or his employment with such contractor.

This report has been reproduced directly from the best available copy.

Printed in USA. Price $\$ 3.00$. Available from the Clearinghouse for Federal Scientific and Technical Information, National Bureau of Standards, U. S. Department of Commerce, Springfield, Virginia 22151. 
NYO-10721

ISOTOPES - INDUSTRIAL

TECHNOLOGY (TID-4500, 28th Ed.)

RADIOISOTOPE SHIELDING DESIGN MANUAL

Prepared by:

William $H$. Steigelmann

Division of Isotopes Development

United States Atomic Energy Commission

Contract No. AT $(30-1) 3042$

July, 1963 
-

0 
TABLE OF CONTENTS

Page

I. INTRODUCTION $\ldots \ldots \ldots \ldots \ldots \ldots \ldots \ldots \ldots \ldots \ldots \ldots, \ldots \ldots \ldots$

II. METHOD OF CALCULATION $\ldots \ldots \ldots \ldots \ldots \ldots \ldots \ldots \ldots$

A. Gamma Radiation...$\ldots \ldots \ldots \ldots \ldots \ldots \ldots \ldots$

B. Bremsstrahlung $\ldots \ldots \ldots \ldots \ldots \ldots \ldots \ldots \ldots \ldots$ ?

C. Neutrons $\ldots \ldots \ldots \ldots \ldots \ldots \ldots \ldots \ldots \ldots, \ldots \ldots \ldots$

III. DOSE RATE AND SHIELDTNG CURVES............... 13

IV. USE OF THE CURVES $\ldots \ldots \ldots \ldots \ldots \ldots \ldots \ldots \ldots . . . \ldots$

APPENDIX A: Radioisotope Data ............. 116

APPENDIX B: Flux: Dose-Rate Conversion Factor and Shielding Properties of

Materials ..................... $\quad 128$ 


\section{INTRODUCTION}

One of the most frequently occurring tasks in radiation shielding work is to determine the required thickness of a given material that is necessary to reduce the radiation dose rate at a given location to a specified value, when the radiation source is a radioisotope that emits $x$ - and gamma-radiations. A related problem is to estimate the radiation dose rate at a given location due to the radiations from a radioisotope source. In this case there may or may not be a shield structure interposed between the radiation source and the dose point. The purpose of this "Radioisotope Shielding Design Manual" is to present a relatively simple and straightforward method for performing these tasks when the radiation source is one of the more frequently used radioactive isotopes. Information is presented for water, ordinary concrete, iron, lead, and uranium as the shielding materials, and for the following sources of radiation:

$\begin{array}{llll}\mathrm{N}^{16} & \mathrm{Kr}^{88} & \mathrm{Sb}^{124} & \mathrm{Ba}^{140} \\ \mathrm{Na}^{24} & \mathrm{Rb}^{88} & \mathrm{I}^{125} & \mathrm{La}^{140} \\ \mathrm{Cr}^{51} & \mathrm{Sr}^{90} & \mathrm{I}^{131} & \mathrm{Ce}^{144}-\mathrm{Pr}^{144} \\ \mathrm{Mn}^{54} & \mathrm{Y}^{90} & \mathrm{Xe}^{131 \mathrm{~m}} & \mathrm{Pm}^{147} \\ \mathrm{Mr}^{56} & \mathrm{Zr}^{95} & \mathrm{I}^{133} & \mathrm{Tm}^{170} \\ \mathrm{Fe}^{59} & \mathrm{Nb}^{95 \mathrm{~m}} & \mathrm{Xe}^{133 \mathrm{~m}} & \mathrm{Ir}^{192} \\ \mathrm{Co}^{60} & \mathrm{Nb}^{95} & \mathrm{Xe}^{133} & \mathrm{Au}^{198} \\ \mathrm{Br}^{84} & \mathrm{Zr}^{97}-\mathrm{Nb}^{97 m} & \mathrm{Cs}^{134} & \mathrm{Po}^{210} \\ \mathrm{Kr}^{85} & \mathrm{Nb}^{97} & \mathrm{I}^{135}-\mathrm{Xe}^{135 \mathrm{~m}} & \mathrm{Pu}^{238} \\ \mathrm{Kr}^{87} & \mathrm{Ru}^{103}-\mathrm{Rh}^{103 \mathrm{~m}} & \mathrm{Xe}^{135} & \mathrm{Am}^{241} \\ & & \mathrm{Cs}^{137}-\mathrm{Ba}^{137 m} & \mathrm{Cm}^{242}\end{array}$

Mixed fission products for the conditions of an infinitely long irradiation time and five specific decay times also have been treated: 


\begin{tabular}{cc} 
Designation & Decay Time \\
\cline { 1 - 2 } MFP-A & 1 hour \\
MFP-B & 1 day \\
MFP-C & 10 days \\
MFP-D & 1 month \\
MFP-E & 6 months
\end{tabular}

Since some of the isotopes listed above are radioactive daughters of other of the isotopes, the daughter-parent combination will occur together in the radiation source. When the half-life of the daughter isotope is short compared to the half-life of the parent, the activity of the daughter will eventually become equal to the activity of the parent, and the daughter is said to be in equilibrium with the parent. In the following cases where this situation may be encountered in radiation shielding work, the shield design information is presented for one curie of the combination of isotopes, as well as for them individually: $\mathrm{Kr}^{88}-\mathrm{Rb}^{88}$, $\mathrm{Sr}^{90}-\mathrm{Y}^{90}, \mathrm{Zr}^{95}-\mathrm{Nb}^{95 \mathrm{~m}}, \mathrm{Zr}^{97}-\mathrm{Nb}^{97 \mathrm{~m}}-\mathrm{Nb}^{97}$, and $\mathrm{Ba}^{140}-\mathrm{La}^{140}$. The radiation dose rate and shield attenuation curves are based upon one curie of the combined activity in each case.

The reason for presenting the information both ways is that the half-life of the daughter is long enough so that equilibrium conditions will not necessarily have been established at the time when the dose rate is to be determined. It should be noted that in the case of the isotope combinations $\mathrm{Zr}^{97}-\mathrm{Nb}^{97 \mathrm{~m}}, \mathrm{Ru}^{103}-\mathrm{Rh}^{103 \mathrm{~m}}, \mathrm{I}^{135}-\mathrm{Xe}^{135 \mathrm{~m}}, \mathrm{Cs}^{137}-\mathrm{Ba}^{137 \mathrm{~m}}$ and $\mathrm{Ce}^{144}-\mathrm{Pr}^{144}$ that were presented in the first listing above, the halflife of the daughter 1sotope is so short that equilibrium conditions will be virtually always encountered.

The shielding design information is presented in the form of curves for the case of a point source of radiation. Any other geometrical form for the radiation source can be approximated by an array of point sources. The radiation dose rate resulting from the emission of gamma rays, bremsstrahlung ( $\mathrm{X}$-rays), and neutrons is considered. 


\section{METHOD OF CALCULATION}

The calculation of the radiation dose rate from a radioisotope source, and the determination of the required thickness of a given material as radiation shielding to reduce the dose rate to a specified level, is often a complicated procedure because most radioisotopes emit gamma photons with a multiplicity of energies, and with a different number of photons per disintegration for each energy. Since the flux-to-dose rate conversion factor and the attenuating properties of the shielding materials are strongly energy dependent, it is necessary to calculate separately the contribution to the total dose rate of each photon energy level or energy group, and then to sum these dose rate components over all the energies for each isotope. When more than a single radioactive isotope species is present, it is necessary to repeat this process for each isotope, and then to add the contributions from each of the radioisotopes in order to determine the total dose rate. The calculations are also complicated somewhat by the variety of units in which the different quantities are given. The basic procedure that is usually followed when attempting to determine the required shielding necessary to meet some specified dose rate criterion involves assuming a number of material thicknesses, calculating the dose rate for each, plotting the results, and interpolating to find the shield thickness corresponding to the permissible dose rate.

The method described and presented in this report makes use of two types of curves: one which gives the unshielded dose rate per curie of source activity as a function of distance from the source, and the other which presents a dose attenuation factor as a function of shield thickness. The energy dependent factors are therefore essentially "pre-calculated" for the shield designer. The remainder of this section will discuss separately the calculation of the gamma, bremsstrahlung, and neutron components of the dose rate. Appendix A presents a detailed tabulation of the particles and radiations emitted by each of the 
isotopes considered. It should be noted that self-absorption or shielding of the radiations by the source material itself has been ignored.

\section{A. Gammá Radiation}

The dose rate, $D_{i}$, at a distance $R$ feet from a point source containing $A_{i}$ curies of radioisotope $i$, with $t$ inches of material $m$ as shielding, is

$$
D_{i}=\frac{3.7 \times 10^{10} A_{i}}{4 \pi[30.48 R]^{2}} \sum_{j} F_{\gamma}\left(E_{j}\right) N_{i}\left(E_{j}\right) G_{m}\left(E_{j}, b_{m}\left(E_{j}\right)\right) \mathrm{mrem} / \mathrm{hr}
$$

where

$$
\begin{gathered}
G_{m}\left(E_{j}, b_{m}\left(E_{j}\right)\right)=B_{m}\left(E_{j}, b_{m}\left(E_{j}\right)\right) e^{-b_{m}\left(E_{j}\right)} \\
b_{m}\left(E_{j}\right)=2.54 \mu_{m}\left(E_{j}\right) t
\end{gathered}
$$

and where

$3.7 \times 10^{10}$ is a conversion constant; disintegrations/second/curie 30.48 is a conversion constant; centimeters/foot $E_{j}$ is the $j^{\text {th }}$ energy level at which gamma photons are emitted from
isotope $i$

$N_{i}\left(E_{j}\right)$ is the number of garma photons emitted with energy $E_{j}$ per disintegration from isotope $i$

$F_{\gamma}\left(E_{j}\right)$ is a conversion factor from garma $f l u x$ to dose rate and is a function of gamma-ray energy; (millirem/hour)/(gamma rays with energy $E_{j}$ /square centimeter-second)

$G_{m}\left(E_{j}, b_{m}\left(E_{j}\right)\right)$ is the dose attenuation factor for the gamma photons with original energy $E_{j}$ 
$b_{m}\left(E_{j}\right)$ is the thickness of the shield expressed in terms of attenuation lengths

2.54 is a conversion constant; centimeters/inch

$\mu_{m}\left(E_{j}\right)$ is the total linear attenuation coefficient for material $m$ and is a function of gamma-ray energy; $\mathrm{cm}^{-1}$

$B_{m}\left(E_{j}, b_{m}\left(E_{j}\right)\right)$ is the dose buildup factor that expresses the ratio of the total dose rate (resulting from both the original, uncollided photons with energy $E_{j}$ and the photons with lower energies that arise from scattering collisions between the original photons and the electrons in the shield material) to the dose rate resulting from the uncollided photons only $e^{-b_{m}\left(E_{j}\right)}$ is the shielding reduction factor for the original gamma photons with energy $E_{j}$

The functions $F_{\gamma}, \mu$, and $B$ are presented in Appendix $B$.

Equation (1) can be re-written in the following equivalent

form

$$
D_{1}=A_{1} \hat{D}_{1} a_{1} \quad \mathrm{mrem} / \mathrm{hr}
$$

where

$$
\begin{aligned}
& \hat{D}_{i}=\frac{3.17 \times 10^{6}}{R^{2}} \sum_{j} F_{\gamma}\left(E_{j}\right) N_{i}\left(E_{j}\right) \text { mrem/hr-curie } \\
& a_{i}=\frac{\sum_{j} F_{\gamma}\left(E_{j}\right) N_{i}\left(E_{j}\right) G_{m}\left(E_{j}, b_{m}\left(E_{j}\right)\right)}{\sum_{j} F_{\gamma}\left(E_{j}\right) N_{i}\left(E_{j}\right)}
\end{aligned}
$$

The function $\hat{D}_{i}$ is therefore the unshielded dose rate per curie of radioisotope $i$, as a function of distance $R$; and $a_{i}$ is the shield attenuation factor. These two functions are presented in the form of "shielding 
design curves" in the following section of this report. The function $\hat{D}_{i}$ is shown for each isotope as a function of $R$, while $a_{i}$ is shown as a function of thickness $t$ for each of the shielding materials considered.

The $a_{i}$ curves presented here can also be used in the case where a shield material has a different density from that used in these calculations (as listed in Appendix $B$ ) by reading the curves at thickness $t=[\rho($ actual $) / \rho($ App. B $)] t$ (actual). The attenuation resulting from the inherent air shielding was not considered in any of the cases treated, since this attenuation is in most cases negligible for distances less than several hundred feet. It should be noted that it is not always permissible to extrapolate the $a_{i}$ curves because of the frequent occurance of high-energy photons that cause the $a_{i}$ curves to have a decreasing slope.

For the mixed-fission products, the gamma-ray emission is expressed in terms of $N_{i}^{*}\left(E_{j}\right)$, photons with energy $E_{j}$ per second per watt of operating power for an essentially infinite operating time in a ruclear fission reactor. In this case, Equations (1), (4), and (5) become, respectively

$$
\begin{aligned}
& D_{i}=\frac{P}{4 \pi[30.48 R]^{2}} \sum_{j} F_{\gamma}\left(E_{j}\right) N_{i}^{*}\left(E_{j}\right) G_{m}\left(E_{j}, b_{m}\left(E_{j}\right)\right) \text { mrem/hr } \\
& D_{i}=P \hat{D}_{i}^{*} a_{i} \\
& \hat{D}_{i}^{* *}=\frac{8.56 \times 10^{-5}}{R^{2}} \sum_{j} F_{\gamma}\left(E_{j}\right) N_{i}^{3 *}\left(E_{j}\right) \text { mrem/hr-watt }
\end{aligned}
$$

where $\mathrm{P}$ is the reactor operating power, in watts. Equation (6) now uses $\mathrm{N}_{i}^{*}$ rather than $\mathrm{N}_{i}$. 


\section{B. Bremsstrahlung}

Bremsstrahlung is the so-called "braking radiation" that is emitted within a material when it is traversed by a charged particle. Since the range of the charged particles is very short, the bremsstrahlung, which are electromagnetic radiations just as are gamma rays and $\mathrm{X}$-rays, are produced within the source itself. The calculation of the total energy intensity emitted during the deceleration of an electron (beta particle) is a very complex procedure. Evans* presents the following equation as a useful approximation.

$$
I=k Z E_{0}^{2}
$$

where $I$ is the bremsstrahlung intensity, $E_{0}$ is the energy of the electron, $Z$ is the atomic number of the stopping material, and $k$ is a constant. Numerical values for the constant $k$ range from $4 \times 10^{-4}$ to $1.1 \times 10^{-3}$, with $7 \times 10^{-4}$ considered to be the "best" value, "when $I$ and $E_{0}$ are expressed in Mev.

The energy spectrum of the bremsstrahlung energy intensity can be approximated as a linearly decreasing function of energy, with the maximum energy equal to $E_{0}$. The number of the photons with energy $E_{0}$ is, however, zero. Therefore, the energy spectrum and number spectrum are

$$
\begin{aligned}
& I(E) d E=2 k Z\left(E_{0}-E\right) d E \\
& N(E) d E=2 k Z\left(\frac{E_{0}}{E}-1\right) d E
\end{aligned}
$$

where $E$ is the photon energy.

The problem is complicated by the fact that the beta rays (particles) that are emitted during the radioactive decay of the isotopes

*R. D. Evans, "The Atomic Nucleus", McGraw-Hill Book Co., Inc., New York, 1955. 
are not mono-energetic, but are emitted with a spectral distribution that ranges from zero energy up to some energy $E_{\max }$, with the number of beta particles being zero at $E_{\max }$.

The procedure that was followed in the calculation of the bremsstrahlung dose rate was to make first an approximate calculation for each isotope listed in Appendix A. For those isotopes for which the bremsstrahlung dose rate showed the possibility of being significant when compared with the gamma dose rate, the beta spectrum was determined by the method given by Marshall.* Each of the beta spectra were then divided into eight equivalent energy groups, and the gamma spectrum was computed by Equation (12) for each of these energy groups. (The same eight energies were used for both the gamma rays and the beta rays.) Finally, the bremsstrahlung dose rate and shield attenuation curves were determined through the use of Equations (1) through (6), but with $N_{i}\left(E_{j}\right)$ and $E_{j}$ being the values computed for the bremsstrahlung.

A value of 26 was used for $Z$ in Equation (12). This value corresponds to the effective $Z$ for strontium titanate, and is also the value for steel. For other values of $\mathrm{Z}$, the $\hat{\mathrm{D}}_{i}$ values can be adjusted by the ratio $\mathrm{Z} / 26$. It was found that the only isotopes for which the bremsstrahlung dose rate exceeded five percent of the gamma-ray dose rate were $\mathrm{Kr}^{85}, \mathrm{Kr}^{87}, \mathrm{Rb}^{88}, \mathrm{Sr}^{90}, \mathrm{r}^{90}, \mathrm{Ce}^{144}-\mathrm{Pr}^{144}, \mathrm{Pm}^{147}$, and $\mathrm{Tm}^{170}$; thus these are the only bremsstrahlung dose rates shown on the curves in section III. The bremsstrahlung photon emission data for these isotopes are presented in Table I. The two highest energy levels have been combined into a single group.

* J. H. Marshall, "How to Figure Shapes of Beta Ray Spectra, Nucleonics", $13: 8$, p. 34, August 1955. 


\section{TABLE I: Bremsstrahlung Emission Data}

$\frac{\text { Radiol sotope }}{K r^{85}}$

$\mathrm{Kr}^{87}$

$\mathrm{Rb}^{88}$

$s r^{90}$

\section{Energy,}

E, Mev

0.610

0.480

0.390

0.305

0.220

0.130

0.043

3.30

2.60

2.15

1.66

1.20

0.71

0.24

4.64

3.64

2.98

2.32

1.66

1.00

0.33

0.480

0.375

0.305

0.240

0.170

0.102

0.034
Emission Per Disintegration ${ }^{*}$

$\begin{array}{ll}\frac{\mathrm{N}_{\beta}(E)}{0.062} & \frac{\mathrm{N}_{x}(E)}{1.3 \times 10^{-5}} \\ 0.103 & 4.2 \times 10^{-5} \\ 0.132 & 1.3 \times 10^{-4} \\ 0.138 & 3.1 \times 10^{-4} \\ 0.162 & 7.3 \times 10^{-4} \\ 0.198 & 1.8 \times 10^{-3} \\ 0.205 & 7.9 \times 10^{-3} \\ 0.049 & 4.7 \times 10^{-5} \\ 0.073 & 1.7 \times 10^{-4} \\ 0.125 & 5.4 \times 10^{-4} \\ 0.149 & 1.5 \times 10^{-3} \\ 0.168 & 3.6 \times 10^{-3} \\ 0.222 & 9.3 \times 10^{-3} \\ 0.214 & 4.0 \times 10^{-2}\end{array}$

0.080

$1.2 \times 10^{-4}$

0.126

$4.0 \times 10^{-4}$

0.161

$8.3 \times 10^{-4}$

0.188

$2.8 \times 10^{-3}$

0.192

$6.5 \times 10^{-3}$

0.165

$1.6 \times 10^{-2}$

0.088

$6.7 \times 10^{-2}$

0.054

$9.0 \times 10^{-6}$

0.099

0.137

$3.0 \times 10^{-5}$

0.138

$9.3 \times 10^{-5}$

0.162

$2.3 \times 10^{-4}$

0.196

$5.5 \times 10^{-4}$

0.214

$1.4 \times 10^{-3}$

$6.0 \times 10^{-3}$ 
TABLE I (Continued)

Radioisotope

$\mathrm{Y}^{90}$
Energy,

E, Mev

2.00

1.55

1.27

0.98

0.70

0.42

0.14

$C e^{144}-\operatorname{Pr}^{144}$

2.75
2.16

1.80

1. 38

0.98

0.59

0.20

$\mathrm{Pm}^{147}$

$\mathrm{Tm}^{170}$
0.21

0.16

0.13

0.102

0.073

0.044

0.015

0.84

0.66

0.54

0.42

0.30

0.18

0.060
Emission Per Disintegration ${ }^{*}$

$\mathrm{N}_{\beta}(\mathrm{E}) \quad \mathrm{N}_{\mathbf{x}}(\mathrm{E})$

0.077

$5.2 \times 10^{-5}$

0.130

$1.8 \times 10^{-4}$

0.157

$5.1 \times 10^{-4}$

0.162

$1.3 \times 10^{-3}$

0.167

$2.9 \times 10^{-3}$

0.174

$7.1 \times 10^{-3}$

0.133

$2.9 \times 10^{-2}$

0.079

$6.3 \times 10^{-5}$

0.142

$2.2 \times 10^{-4}$

0.158

$8.2 \times 10^{-4}$

0.163

$1.5 \times 10^{-3}$

0.165

$3.9 \times 10^{-3}$

0.166

$9.4 \times 10^{-3}$

1.127

$4.3 \times 10^{-2}$

0.045

0.108

$3.1 \times 10^{-6}$

0.142

$1.2 \times 10^{-5}$

0.106

$3.9 \times 10^{-5}$

$9.8 \times 10^{-5}$

0.148

$2.3 \times 10^{-4}$

0.208

$5.8 \times 10^{-4}$

0.243

$2.5 \times 10^{-3}$

0.038

$8.2 \times 10^{-6}$

0.089

$3.9 \times 10^{-5}$

0.132

$1.3 \times 10^{-4}$

0.149

$3.6 \times 10^{-4}$

0.169

$8.7 \times 10^{-3}$

0.198

$2.3 \times 10^{-3}$

0.225

$1.0 \times 10^{-2}$

${ }^{*} \mathrm{~N}_{\beta}=$ Number of beta particles in each energy group

$\mathrm{N}_{\mathrm{x}}^{\beta}=$ Number of bremsstrahlung photons in each group. 


\section{Neutrons}

The only isotopes for which neutron emission is treated here are $\mathrm{Pu}^{238}$ and $\mathrm{Cm}^{242}$, both of which undergo spontaneous fission. It must be noted, however, that these isotopes and others such as $\mathrm{Po}^{210}$ and $\mathrm{Am}^{24 \mathrm{I}}$ also emit alpha particles and these can cause $(\alpha, n)$ reactions with other materials that may be present with the isotope. The $(\alpha, n)$ reaction may result in a much greater neutron flux than that from spontaneous fission. For these reasons, and because of the scarcity of data concerning the neutron emission data for spontaneous fission, the neutron dose rate and shielding calculations have been treated in an approximate manner. Because only spontaneous fission is considered here, the user of these curves should exercise caution to see whether $(\alpha, n)$ reactions need to be considered also.

Corresponding to Equation (5), the unshielded neutron dose rate per unit activity, $\hat{\mathrm{D}}_{i}$ was calculated from the equation:

$$
\hat{D}_{i}=\frac{3.17 \times 10^{6}}{R^{2}} \vec{F}_{n} v_{i} \quad \text { mrem } / \mathrm{hr} \text {-curie }
$$

Where $\bar{F}_{n}$ is an average neutron flux: dose rate conversion factor and $v_{i}$ is the average number of neutrons released per disintegration. Data on $v_{i}$ are presented in Appendix A. Referring to Figure B-1 in Appendix $B$, it can be seen the value of $\vec{F}_{n}$ is approximately constant for neutron. energies greater than about one Mev. Since most of the neutrons released during spontaneous fission probably have energies in excess of one Mev, a value of $0.13(\mathrm{mrem} / \mathrm{hr}) /\left(\mathrm{n} / \mathrm{cm}^{2}-\mathrm{sec}\right)$ will be used for $\overline{\mathrm{F}}_{\mathrm{n}}$.

With regard to the dose attenuation curves for the two neutron sources, approximate shielding information will be presented, as discussed in Glasstone and Sesonske* and Blizard. ${ }^{*}$ In all cases, the shielding

\footnotetext{
*S.Glasstone and A. Sesonske, Nuclear Reactor Engineering, D. Van Nostrand Co., Inc., New York, 1963

E.P. Blizard (Ed.), Reactor Handbook, 2nd Ed; Volume III, Part B, Shielding, Interscience Publishers, New York, 1962.
} 
curves will be based on data for the fission neutron spectrum of U-235. For water, the expression for the point kernel given in Eg. 10.32 of Glasstone and Sesonske will be used as the basis for the $a_{1}$ curves. For concrete, a relaxation length of $12 \mathrm{~cm}$ (as reported in both references) will be used. For steel and lead, relaxation lengths of $16 \mathrm{~cm}$ and $24 \mathrm{~cm}$, respectively, will be assumed (from the Blizard reference). For uranium, it will be assumed that the attenuation is negligible, since (a) the relaxation length is probably large, and (b) additional neutrons will be produced within the shield as a result of the neutron-induced fastfission reaction.

The appropriate expressions for $a_{i}$ are therefore

$\begin{array}{ll}\text { For water: } & a_{i}=0.892 \mathrm{e}^{-0.328 t}+0.108 \mathrm{e}^{-0.231 t} \\ \text { For concrete: } & a_{i}=e^{-0.212 t} \\ \text { For steel: } & a_{i}=e^{-0.159 t} \\ \text { For lead: } & a_{i}=e^{-0.106 t} \\ \text { For uranium: } & a_{i}=1\end{array}$

where $t$ is expressed in inches. 


\section{DOSE RATE AND SHIELDING CURVES}

The radiation dose rate curves and shield attenuation curves are presented in sixteen sets of figures, each set presenting information on one group of radioisotopes. In each set, the first figure, A, shows the shielded dose rate, $\hat{D}_{1}$ or $\hat{D}_{1}^{*}$, as a function of distance from a point source of the radioisotope. The dose rate information is presented separately for gamma rays, bremsstrahlung $X$-rays, and neutrons. (Where only gamma radiation is considered, the curves are not designated with regard to the type of radiation.) In all cases, it is assumed that the charged particle radiations ( $\alpha$-rays and $\beta$-rays) are completely stopped within the source and its container or cladding (the dose rate from these radiations is not considered in this report). The remaining figures in each set $\left(B, C, D, E\right.$, and $F$ ) present the shield attenuation factors, $a_{i}$, for the cases where water, ordinary concrete, steel, lead, and uranium are the shield materials. The radioisotopes are grouped, and the groups are presented in order of increasing mass number. Some deviations from the mass number sequence has been necessary, however, in the interest of minimizing the confusion as to which curve corresponds to which isotope. Table II presents an index to the figures and shows where the information on the various isotopes may be found.

In using these curves, it should be remembered that the unshielded dose rate does not include the self-shielding contributed by the source itself (except as regards the charged particles, as discussed above). In some instances, as shown in the shield attenuation factor curves, a very small thickness of material can make a great difference in the dose rate, and therefore the source self-shielding can at times be quite significant.

It may be noted that some of the $\alpha_{i}$ curves initially rise to values greater than unity instead of monotonically decreasing. This behavior occurs with low-energy photons in light-weight shielding 
materials (such as water) and is the result of the buildup and accumulation of the very low energy photons which are biologically very harmful. (The $F_{Y}$ curve in Figure $B-I$ increases with decreasing energy for photon energies less than about $60 \mathrm{Kev}$.) Another reason for the initial rise is that the curves are based upon infinite medium buildup factors. Since these very low energy photons are readily absorbed by a heavier material (such as the container for the water) and since a finite shield will have a smaller buildup factor than an infinite shield because the backscatter will be less, the initial rise in the $a_{i}$ curves should not be taken at face value. Also, the shape of the curve in the "peaked" region is not well defined. The curves are conservative in that they predict dose rates values that are greater than those expected to occur in an actual situation. 
TABLE II: Index to the Shielding Design Curves

FIGURE NO.

\begin{tabular}{|c|c|c|c|c|c|c|}
\hline RADIOISOTOPE & $\mathrm{D}_{1}$ or $\mathrm{D}_{1}^{*}$ & $\alpha_{1}$ for water & $\alpha_{1}$ for concrete & $\alpha_{1}$ for steel & $\alpha_{1}$ for lead & $\alpha_{1}$ for urentum \\
\hline $\mathrm{N}^{16}$ & $1 \mathrm{~A}$ & 18 & IC & $1 D$ & $1 E$ & $1 F$ \\
\hline $\mathrm{Na}^{24}$ & $2 A$ & $2 \mathrm{~B}$ & $2 \mathrm{C}$ & $2 \mathrm{D}$ & $2 \mathrm{E}$ & $2 F$ \\
\hline $\mathrm{Cr}^{51}$ & $2 \mathrm{~A}$ & $2 B$ & $2 C$ & $2 \mathrm{D}$ & $2 \mathrm{E}$ & $2 F$ \\
\hline $\mathrm{Mn}^{54}$ & $1 \mathrm{~A}$ & $1 B$ & $1 C$ & 10 & $1 E$ & $1 F$ \\
\hline $\operatorname{Mn}^{56}$ & $2 \mathrm{~A}$ & $2 B$ & $2 C$ & 2D & $2 E$ & $2 F$ \\
\hline $\mathrm{Fe}^{59}$ & $1 \mathrm{~A}$ & $1 B$ & IC & ID & $1 E$ & $1 F$ \\
\hline $\mathrm{Co}^{60}$ & $2 A$ & 2B & $2 \mathrm{C}$ & $2 \mathrm{D}$ & $2 E$ & $2 F$ \\
\hline $\mathrm{Br}^{84}$ & $4 \mathrm{~A}$ & 4B & $4 \mathrm{C}$ & 40 & $4 E$ & $4 F$ \\
\hline $\mathbf{K r}^{85}$ & $3 A$ & $3 B$ & $3 C$ & $3 D$ & $3 E$ & $3 F$ \\
\hline $\mathrm{Kr} r^{87}$ & $3 A$ & $3 B$ & $3 \mathrm{C}$ & $3 \mathrm{D}$ & $3 E$ & $3 F$ \\
\hline $\mathrm{Kr}^{88}$ & $4 \mathrm{~A}$ & $4 B$ & $4 \mathrm{C}$ & 4D & $4 E$ & $4 \mathrm{~F}$ \\
\hline $\mathrm{Rb}^{88}$ & $4 A$ & $4 B$ & $4 c$ & 4D & $4 E$ & $4 F$ \\
\hline $\mathrm{Kr}^{88}-\mathrm{Br}^{88}$ & $4 A$ & $4 B$ & $4 c$ & 4D & $4 E$ & 45 \\
\hline $\mathrm{Sr}^{90}$ & $5 \mathrm{~A}$ & $5 B$ & $5 \mathrm{C}$ & 5D & $5 E$ & $5 F$ \\
\hline $\mathrm{Y}^{90}$ & $5 A$ & $5 B$ & 50 & 5D & $5 E$ & $5 \mathrm{~F}$ \\
\hline $5 r^{90}-\gamma^{90}$ & $5 A$ & $5 B$ & $5 \mathrm{C}$ & $5 \mathrm{D}$ & $5 E$ & $5 F$ \\
\hline $2 r^{95}$ & $6 A$ & $6 \mathrm{~B}$ & $6 \mathrm{c}$ & 60 & 68 & $6 F$ \\
\hline $\mathrm{Nb}^{95 \mathrm{~m}}$ & $6 A$ & $6 \mathrm{~B}$ & $6 \mathrm{c}$ & $6 \mathrm{D}$ & $6 E$ & $6 F$ \\
\hline $2 r^{95}-\mathrm{Nb}^{95 m}$ & $6 A$ & $6 B$ & $6 \mathrm{c}$ & 60 & $6 E$ & $6 F$ \\
\hline $\mathrm{Nb}^{95}$ & $7 \mathrm{~A}$ & 78 & $7 \mathrm{c}$ & 70 & $7 E$ & $7 F$ \\
\hline $2 r^{97}-N^{97 m}$ & $8 A$ & $8 \mathrm{~B}$ & $8 \mathrm{c}$ & $8 D$ & $8 \mathrm{E}$ & $8 \mathrm{~F}$ \\
\hline $\mathrm{Nb} 97$ & $8 \mathrm{~A}$ & BB & $8 \mathrm{c}$ & $8 D$ & $8 E$ & $8 F$ \\
\hline $\mathrm{Zr} 97-\mathrm{Nb} 97 \mathrm{~m}-\mathrm{Nb} 97$ & $8 A$ & $8 \mathrm{~B}$ & $8 \mathrm{c}$ & $8 \mathrm{~b}$ & $8 \mathrm{E}$ & $8 F$ \\
\hline
\end{tabular}


TABLE II: Index to the Shielding Design Curves (Continued)

FIGURE NO

\begin{tabular}{|c|c|c|c|c|c|c|}
\hline \multirow[b]{2}{*}{ RADIOISOTOPE } & \\
\hline & $\mathrm{D}_{1}$ or $\mathrm{D}_{1} *$ & $\alpha_{1 \text { for water }}$ & $\alpha_{1 \text { for concrete }}$ & $a_{1 \text { for steel }}$ & $a_{1 \text { for loed }}$ & $\alpha_{1 \text { for urenium }}$ \\
\hline $\mathrm{Ru}^{103}-\mathrm{Rh}^{103 m}$ & $7 A$ & $7 B$ & $7 \mathrm{C}$ & $7 \mathrm{D}$ & $7 \mathrm{E}$ & $7 F$ \\
\hline $\mathrm{Sb}^{124}$ & $9 A$ & $9 \mathrm{~B}$ & $9 \mathrm{C}$ & $9 D$ & $9 \mathrm{E}$ & $9 F$ \\
\hline$I^{125}$ & $9 A$ & $9 \mathrm{~B}$ & 90 & $9 D$ & $9 \vec{E}$ & $9 F$ \\
\hline$I^{131}$ & $9 A$ & $9 \mathrm{~B}$ & 90 & $9 \mathrm{D}$ & $9 \mathrm{E}$ & $9 F$ \\
\hline $\mathrm{Xe}^{131 \mathrm{~m}}$ & $9 A$ & $9 \mathrm{~B}$ & 90 & $9 D$ & $9 E$ & $9 F$ \\
\hline$I^{133}$ & $10 \mathrm{~A}$ & $10 B$ & 100 & $10 D$ & $10 E$ & $10 F$ \\
\hline$x_{\theta} 133 \mathrm{~m}$ & $10 \mathrm{~A}$ & $10 \mathrm{~B}$ & $10 \mathrm{C}$ & $10 \mathrm{D}$ & $10 \mathrm{E}$ & 10F \\
\hline $\mathrm{Xe}_{0} 133$ & $10 \mathrm{~A}$ & $10 \mathrm{~B}$ & $10 \mathrm{C}$ & 10D & $10 E$ & $10 F$ \\
\hline $\mathrm{Cs}^{134}$ & $10 \mathrm{~A}$ & $10 \mathrm{~B}$ & $10 \mathrm{C}$ & $10 \mathrm{D}$ & $10 E$ & $10 F$ \\
\hline$I^{135-X_{\theta}} 135 \mathrm{~m}$ & $21 \mathrm{~A}$ & $11 B$ & $11 \mathrm{C}$ & 110 & $11 E$ & $11 F$ \\
\hline $\mathrm{Xe}^{135}$ & $11 \mathrm{~A}$ & $11 B$ & $11 \mathrm{C}$ & IID & $11 E$ & $21 F$ \\
\hline $\mathrm{Cs}^{137}-\mathrm{Be}^{137 m}$ & $11 A$ & $11 \mathrm{~B}$ & $11 \mathrm{C}$ & 110 & $11 \mathrm{E}$ & $21 F$ \\
\hline $\mathrm{Ba} 140$ & $12 \mathrm{~A}$ & $12 B$ & $12 \mathrm{C}$ & $12 \mathrm{D}$ & $12 \mathrm{E}$ & $12 F$ \\
\hline $\mathrm{La}^{140}$ & $12 \mathrm{~A}$ & $12 \mathrm{~B}$ & $12 \mathrm{C}$ & $12 \mathrm{D}$ & $12 \mathrm{E}$ & $12 \mathrm{~F}$ \\
\hline $\mathrm{Ba}^{140}-\mathrm{La}^{140}$ & $12 \mathrm{~A}$ & $12 B$ & $12 \mathrm{C}$ & 12D & $12 E$ & $12 \mathrm{~F}$ \\
\hline $\mathrm{Ce}^{144}-\mathrm{Pr}^{144}$ & $24 \mathrm{~A}$ & 148 & $14 \mathrm{C}$ & 14D & $14 E$ & $14 \mathrm{~F}$ \\
\hline $\mathrm{Pm}^{147}$ & $13 A$ & $13 B$ & $13 \mathrm{C}$ & $13 D$ & $13 E$ & $13 F$ \\
\hline $\mathrm{Tm} 170$ & $3 A$ & $3 B$ & $3 c$ & 3D & $3 E$ & $3 F$ \\
\hline $\mathrm{Ir}^{192}$ & $15 \mathrm{~A}$ & $15 B$ & $15 \mathrm{C}$ & $15 D$ & $15 E$ & $15 \mathrm{~F}$ \\
\hline$A u^{198}$ & $14 A$ & $14 \mathrm{~B}$ & $24 c$ & 14D & $14 \mathrm{E}$ & $14 \mathrm{~F}$ \\
\hline $\mathrm{Po}^{210}$ & $13 A$ & $13 B$ & $13 \mathrm{C}$ & 13D & $13 \mathrm{E}$ & $13 F$ \\
\hline $\mathrm{Pu}^{238}$ & $24 \mathrm{~A}$ & $14 \mathrm{~B}$ & $14 c$ & $14 \mathrm{D}$ & $14 \mathrm{E}$ & $14 \mathrm{~F}$ \\
\hline $\mathrm{Am}^{241}$ & $15 \mathrm{~A}$ & $15 B$ & $15 \mathrm{C}$ & $15 D$ & $15 E$ & $15 F$ \\
\hline $\mathrm{Cm}^{242}$ & $15 \mathrm{~A}$ & $15 \mathrm{~B}$ & $15 \mathrm{C}$ & $15 D$ & $15 E$ & $15 \mathrm{~F}$ \\
\hline$M M P-A$ & $16 A$ & $16 \mathrm{~B}$ & $16 \mathrm{c}$ & $16 \mathrm{D}$ & $16 \mathrm{E}$ & $16 F$ \\
\hline MFP-B & $16 A$ & $16 B$ & $16 \mathrm{C}$ & $16 \mathrm{D}$ & $16 E$ & $16 F$ \\
\hline $\mathrm{MFP}-\mathrm{C}$ & $16 \mathrm{~A}$ & $16 \mathrm{~B}$ & 160 & 160 & $16 \mathrm{E}$ & $16 \mathrm{~F}$ \\
\hline MFP-D & $16 \mathrm{~A}$ & $16 \mathrm{~B}$ & $16 \mathrm{C}$ & $16 \mathrm{D}$ & $26 E$ & $16 F$ \\
\hline MFP-E & $16 \mathrm{~A}$ & $16 \mathrm{~B}$ & $16 \mathrm{C}$ & $16 \mathrm{D}$ & $16 \mathrm{E}$ & $16 \mathrm{~F}$ \\
\hline
\end{tabular}




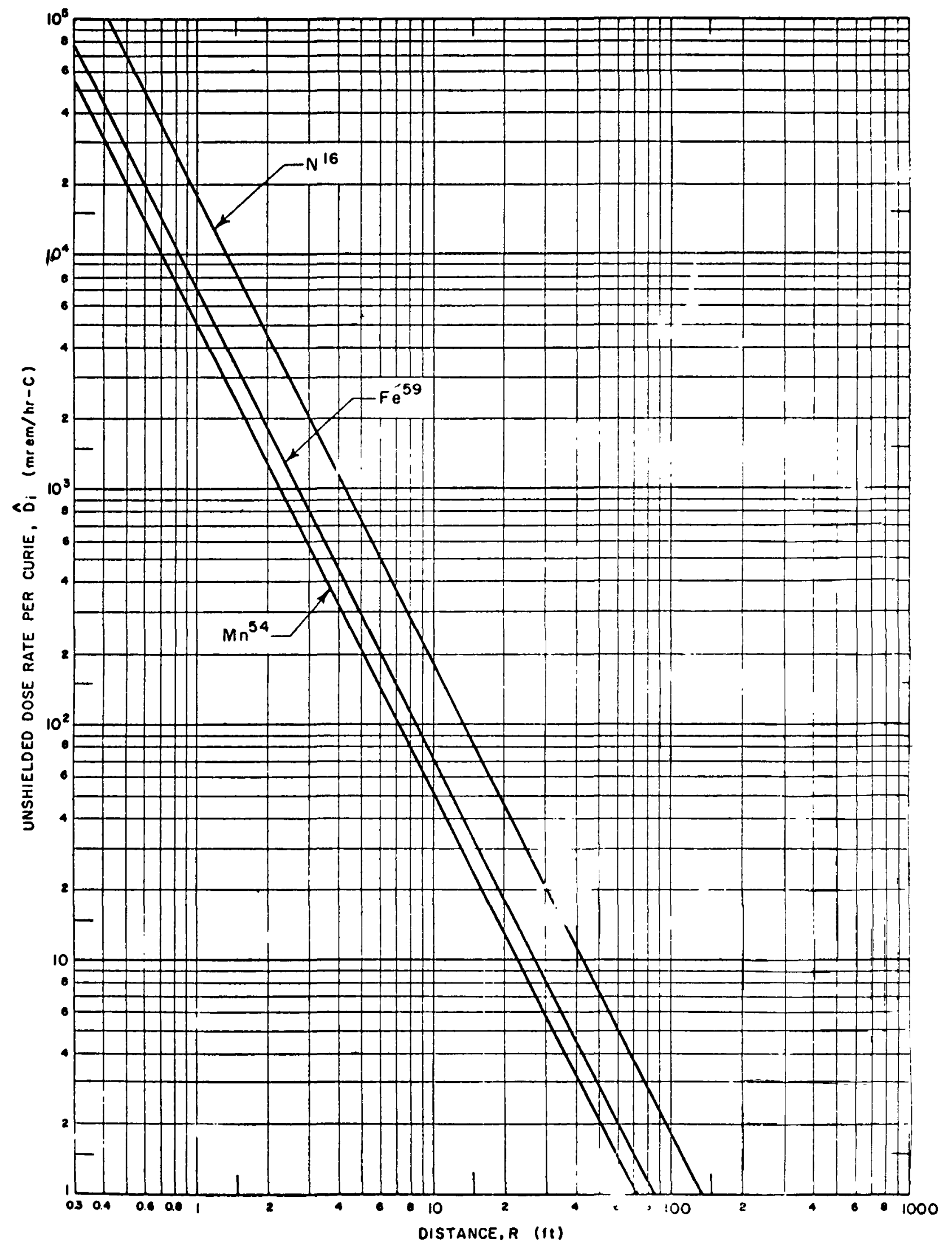

FIGURE IA 


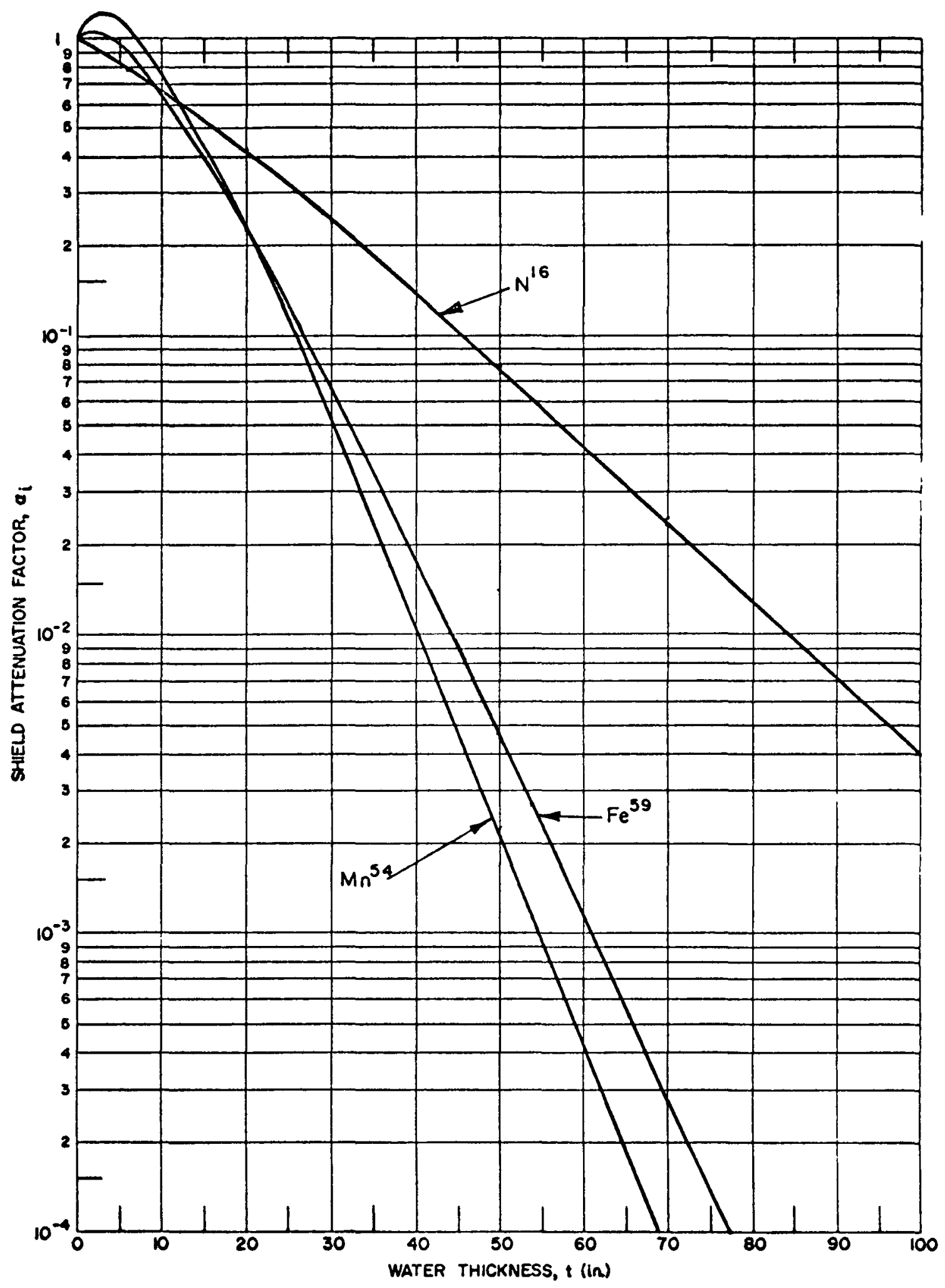

FIGURE IB 


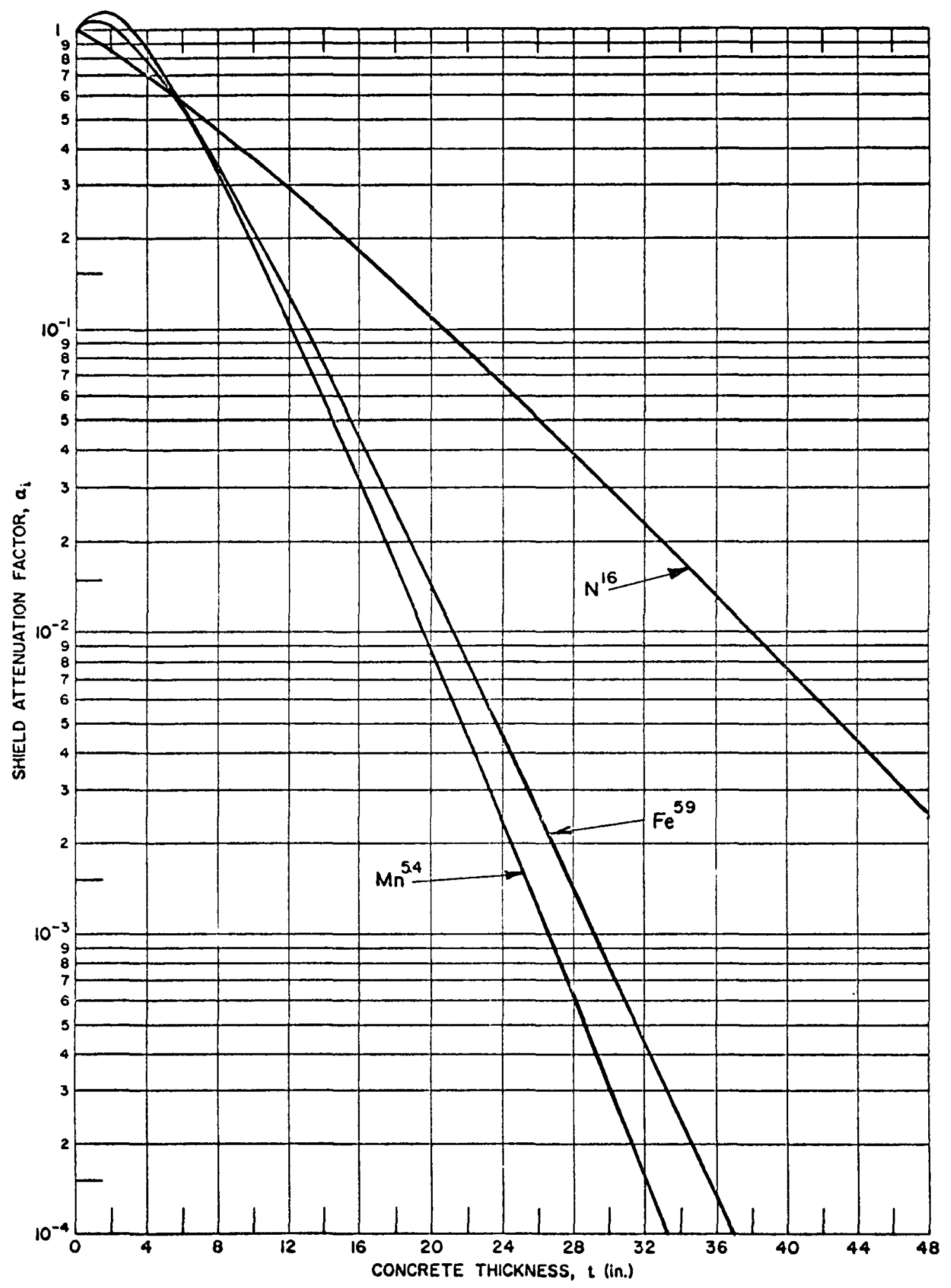

FIGURE IC

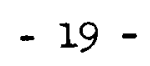




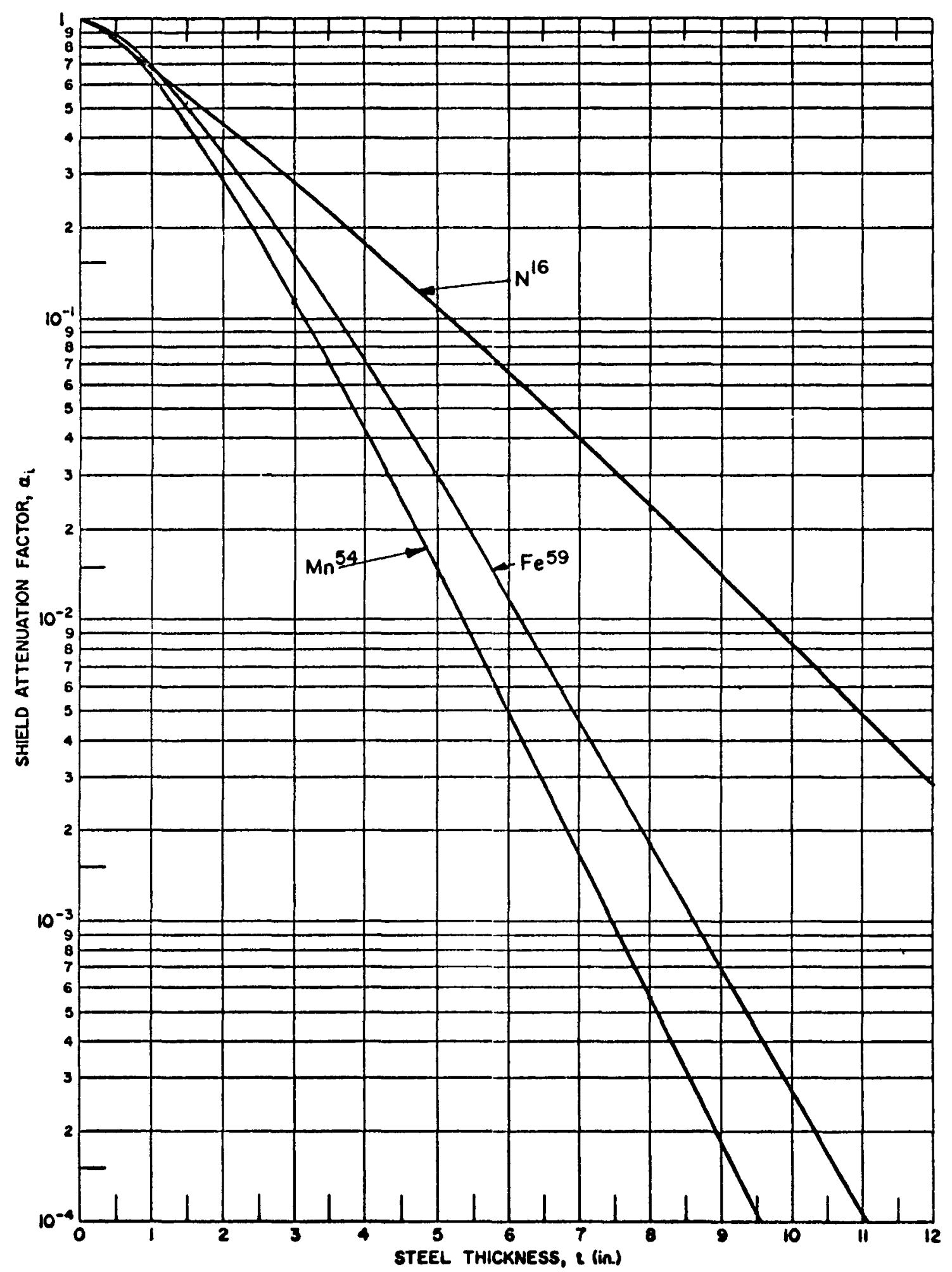

FIGURE ID 


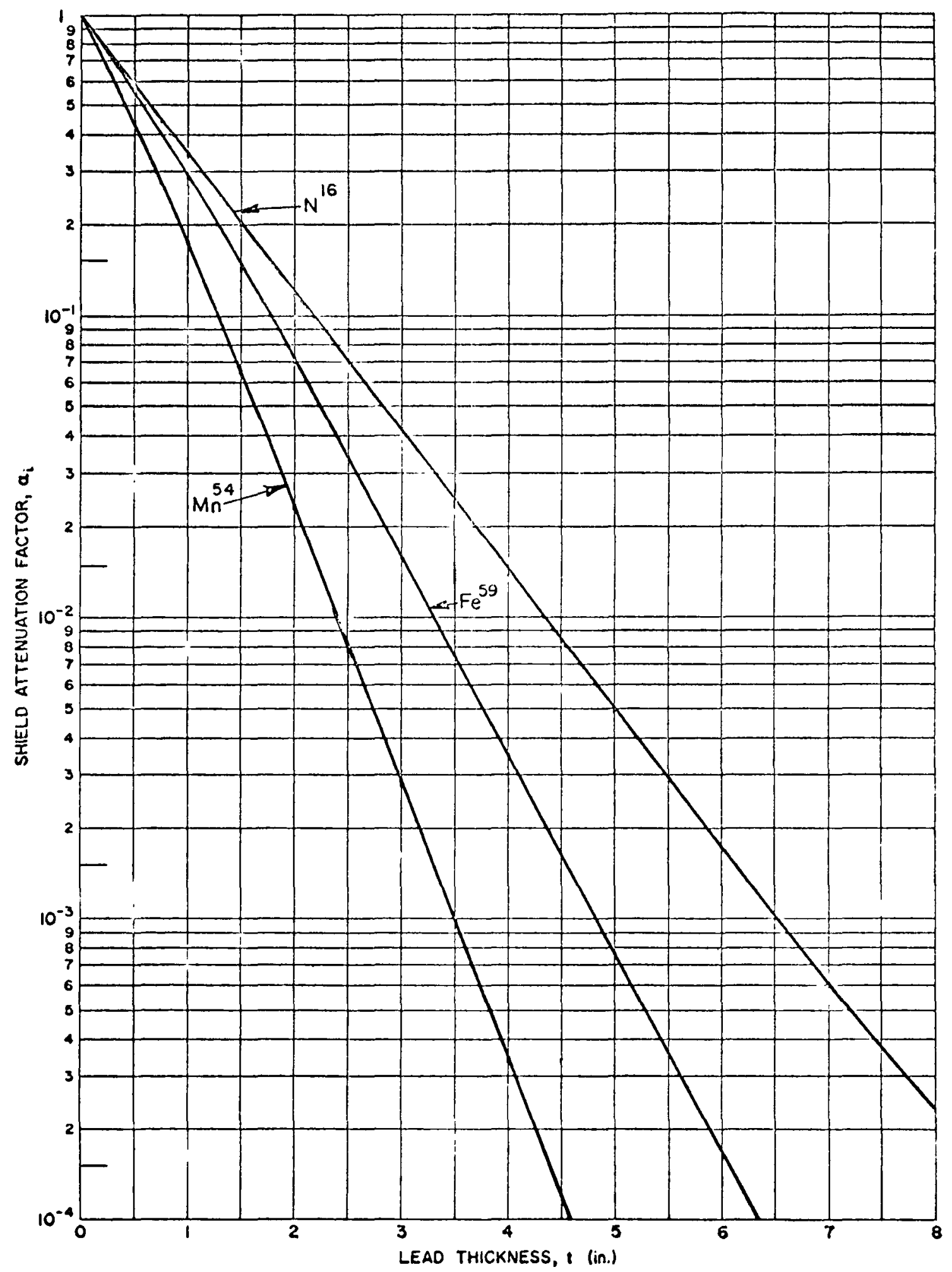

FIGURE IE 


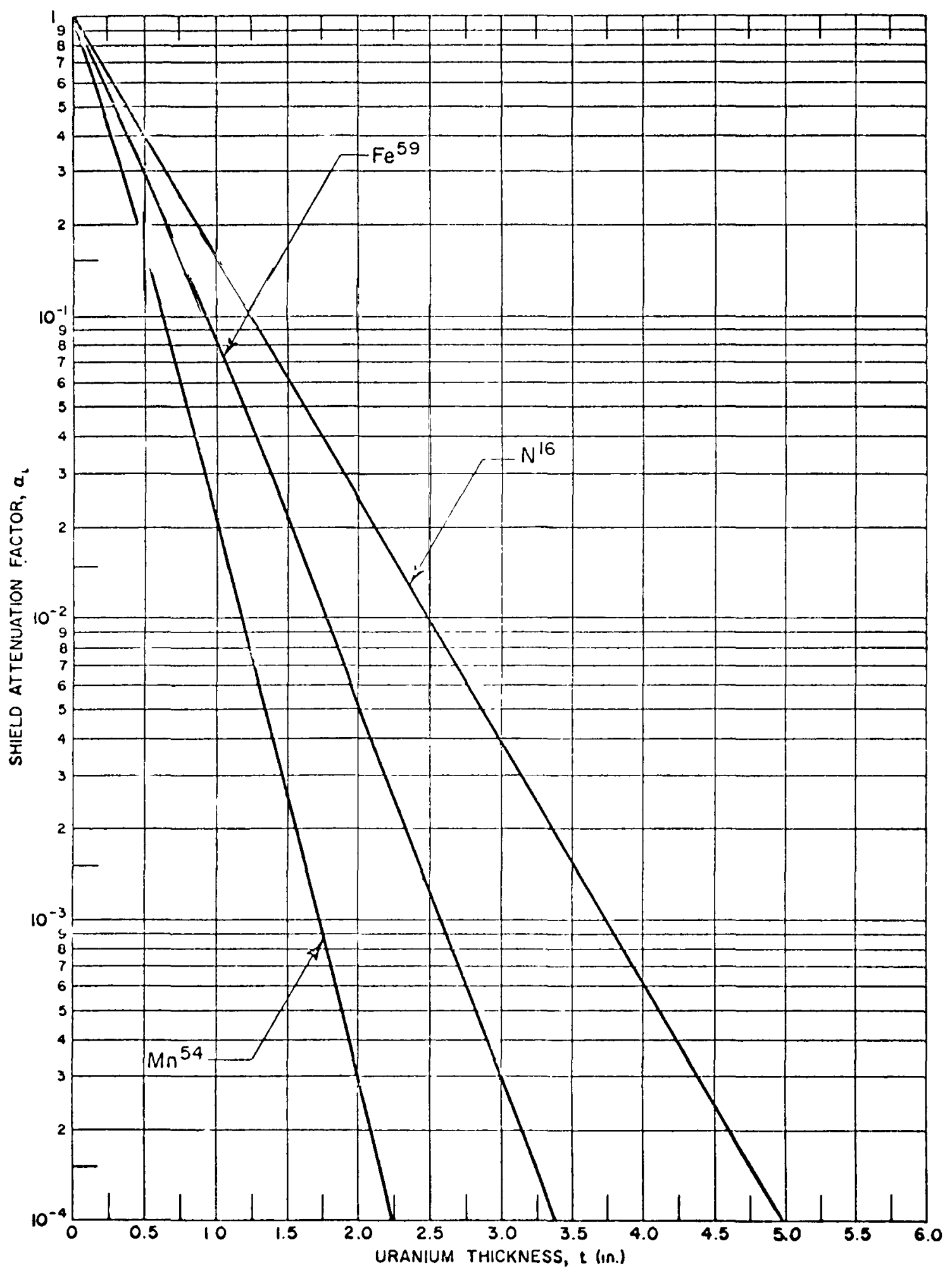

FIGURE IF 


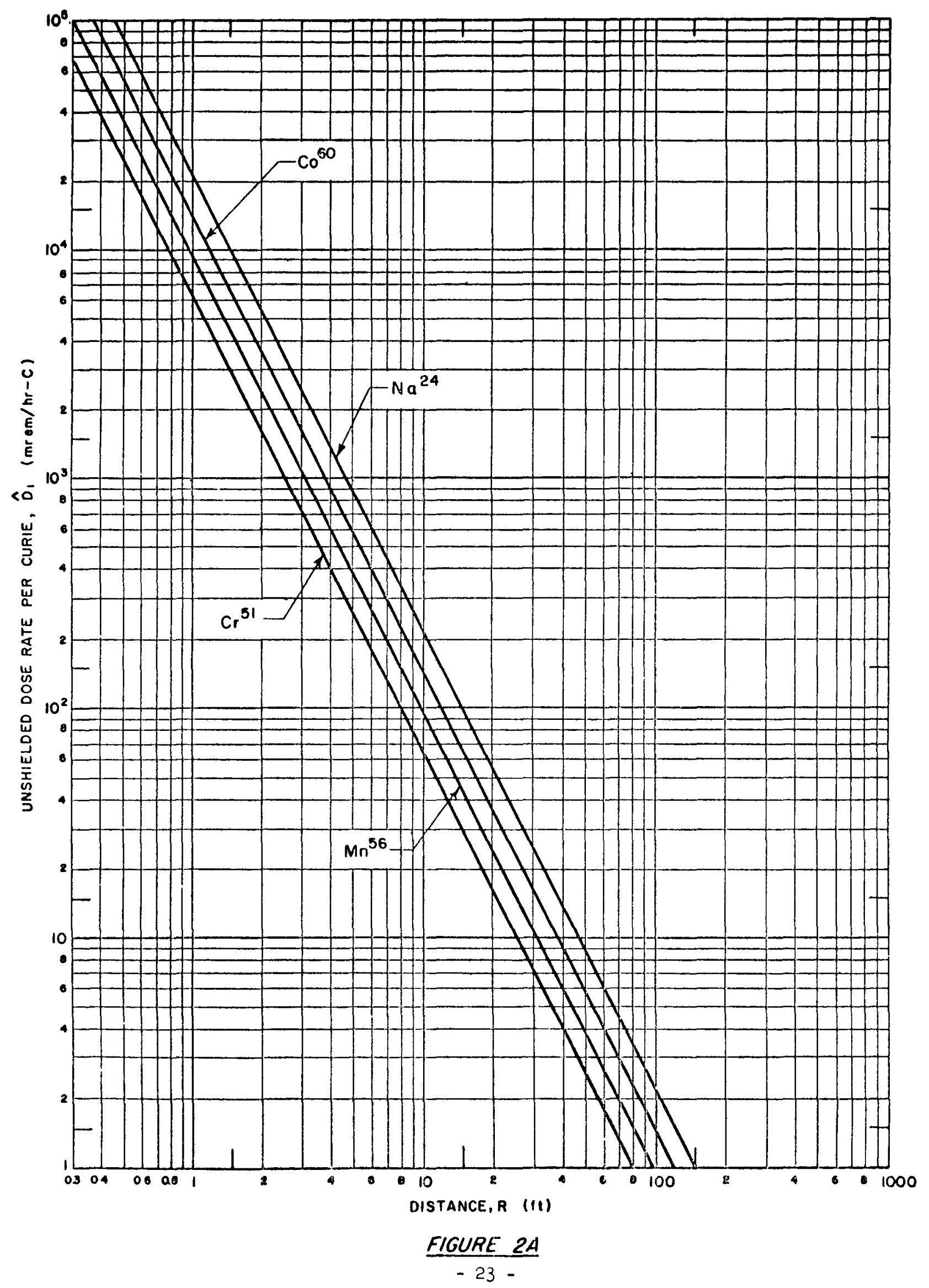




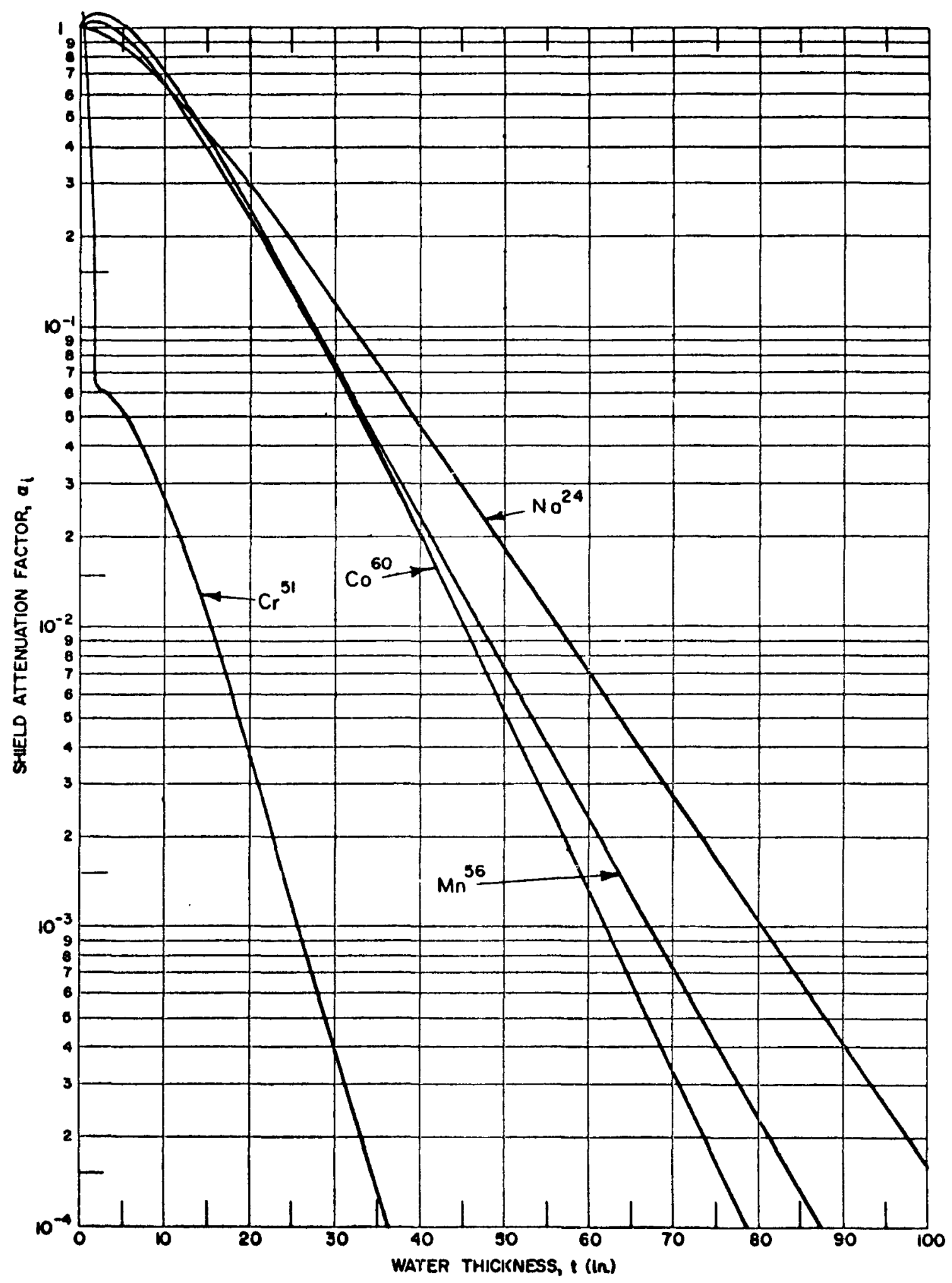

FIGURE $2 B$ 


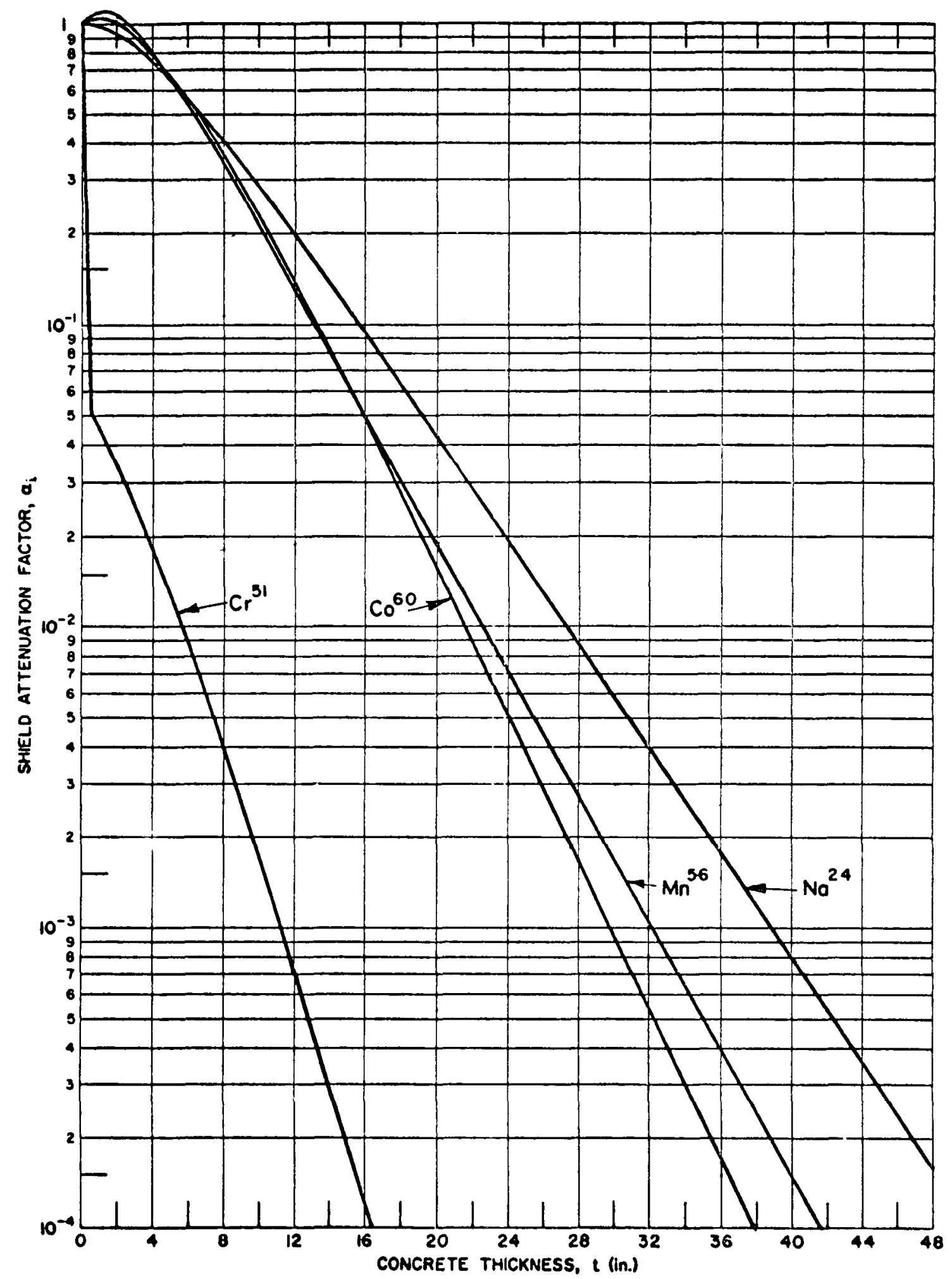

FIGURE 2C 


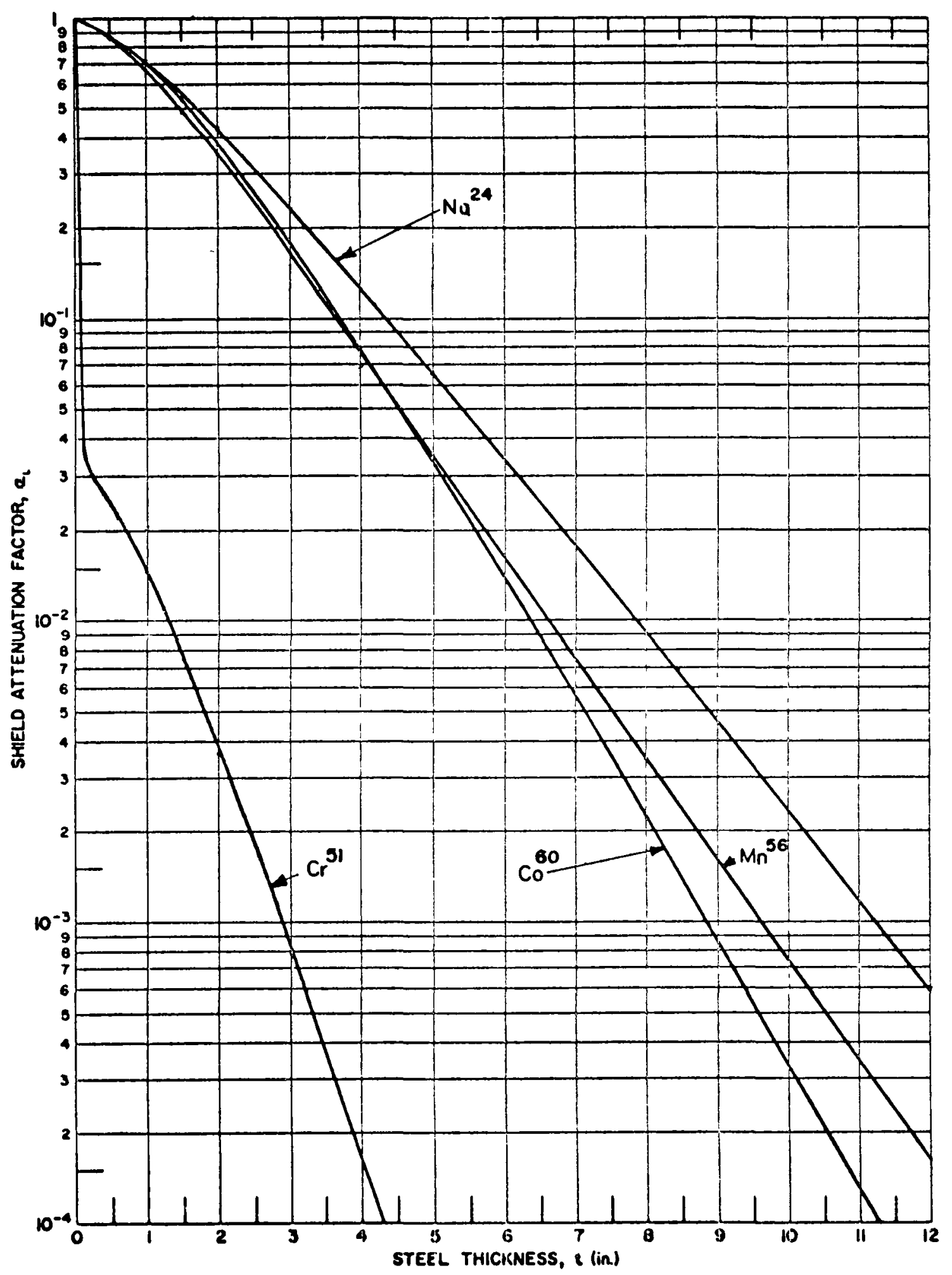

FIGURE 20 


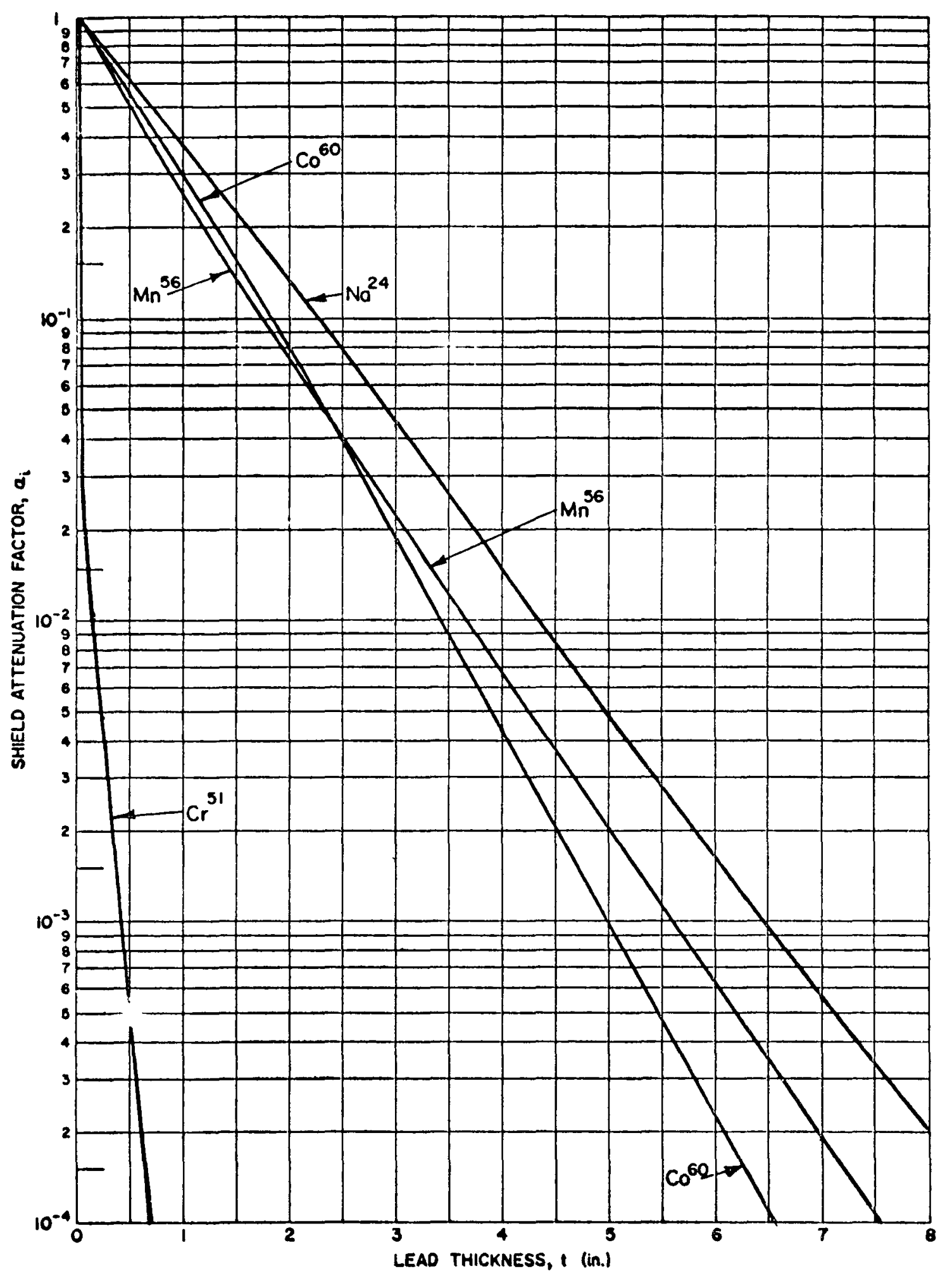

FIGURE $2 E$ 


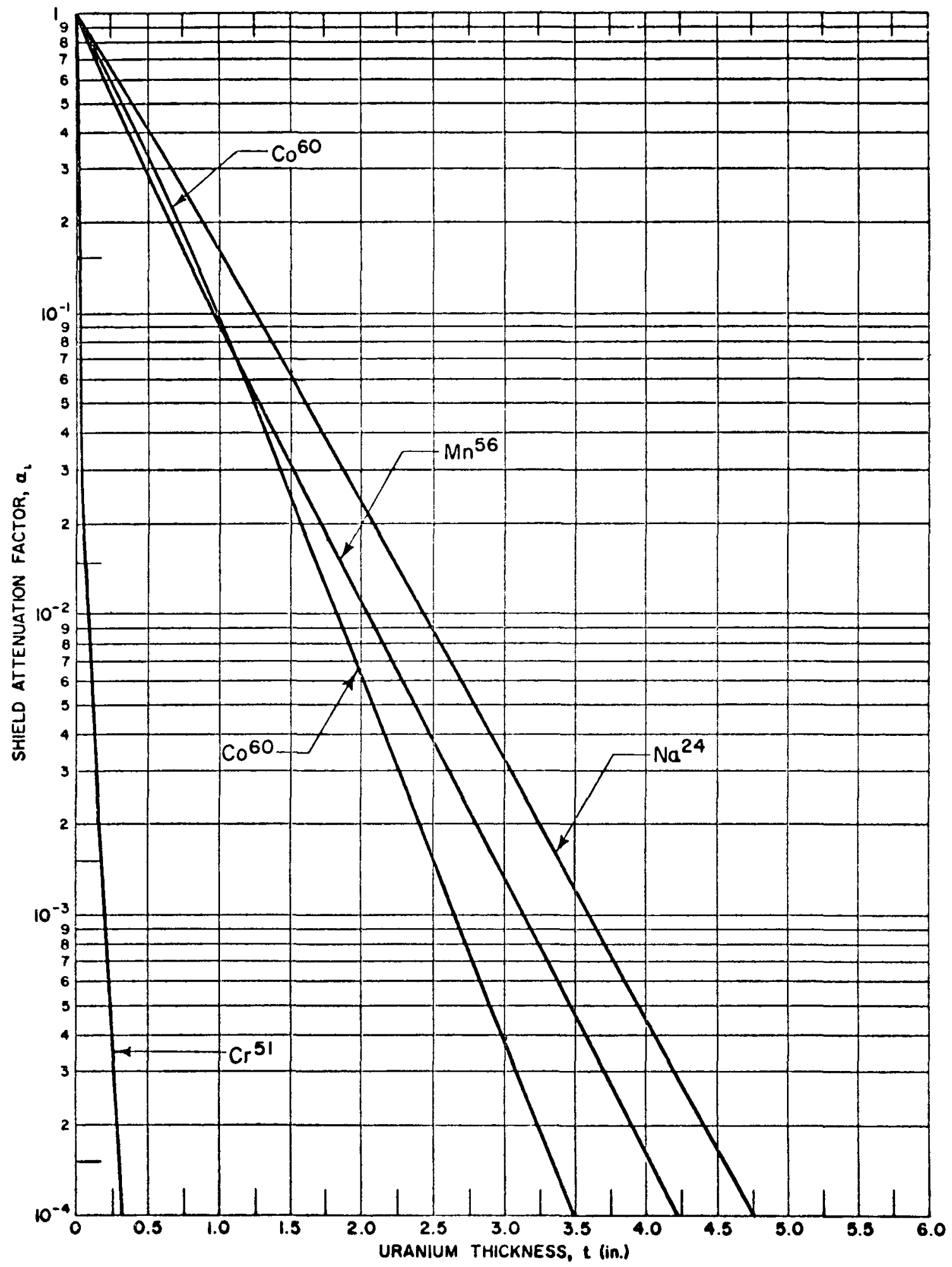

FIGURE 2F

-28 - 


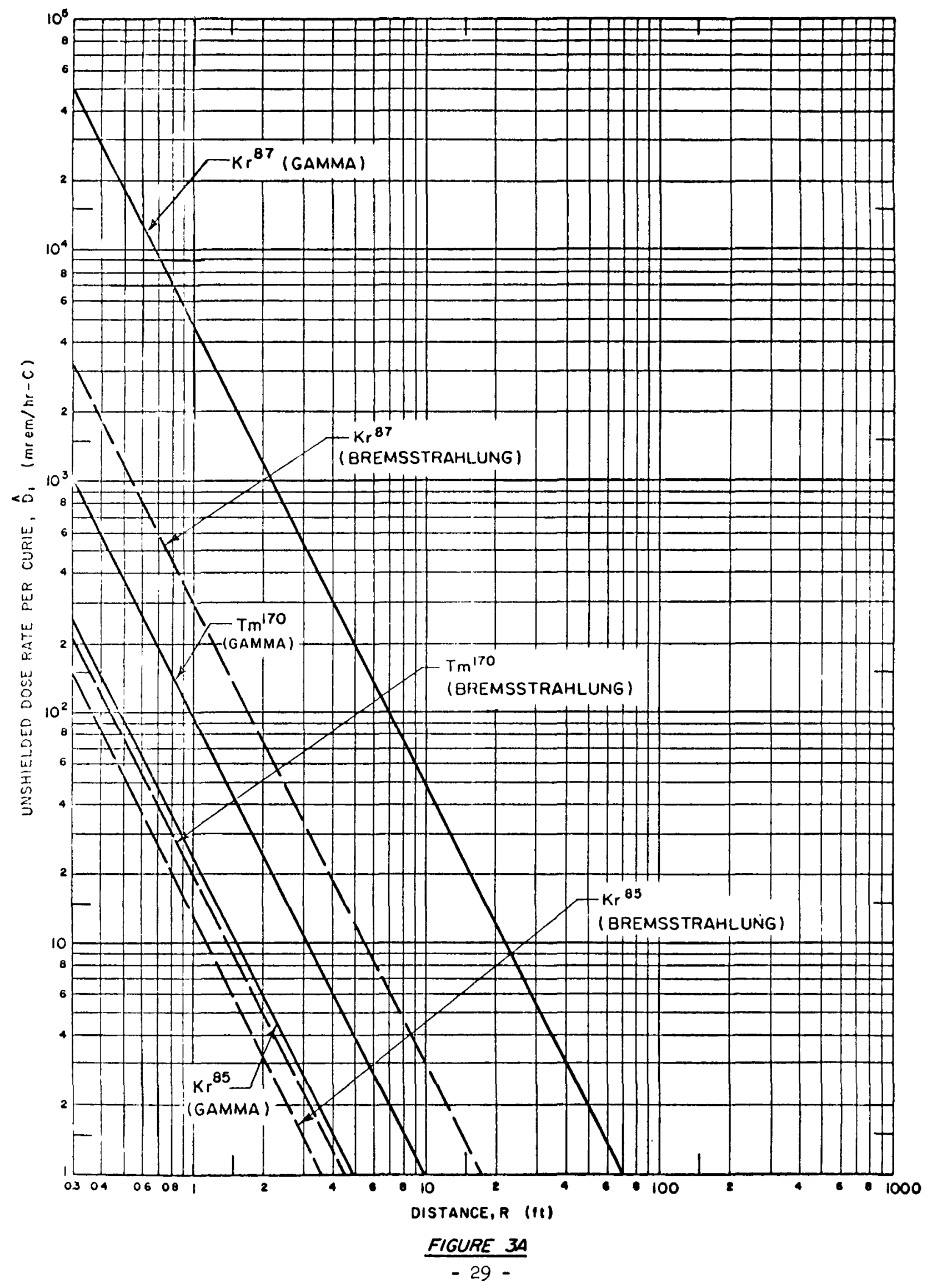




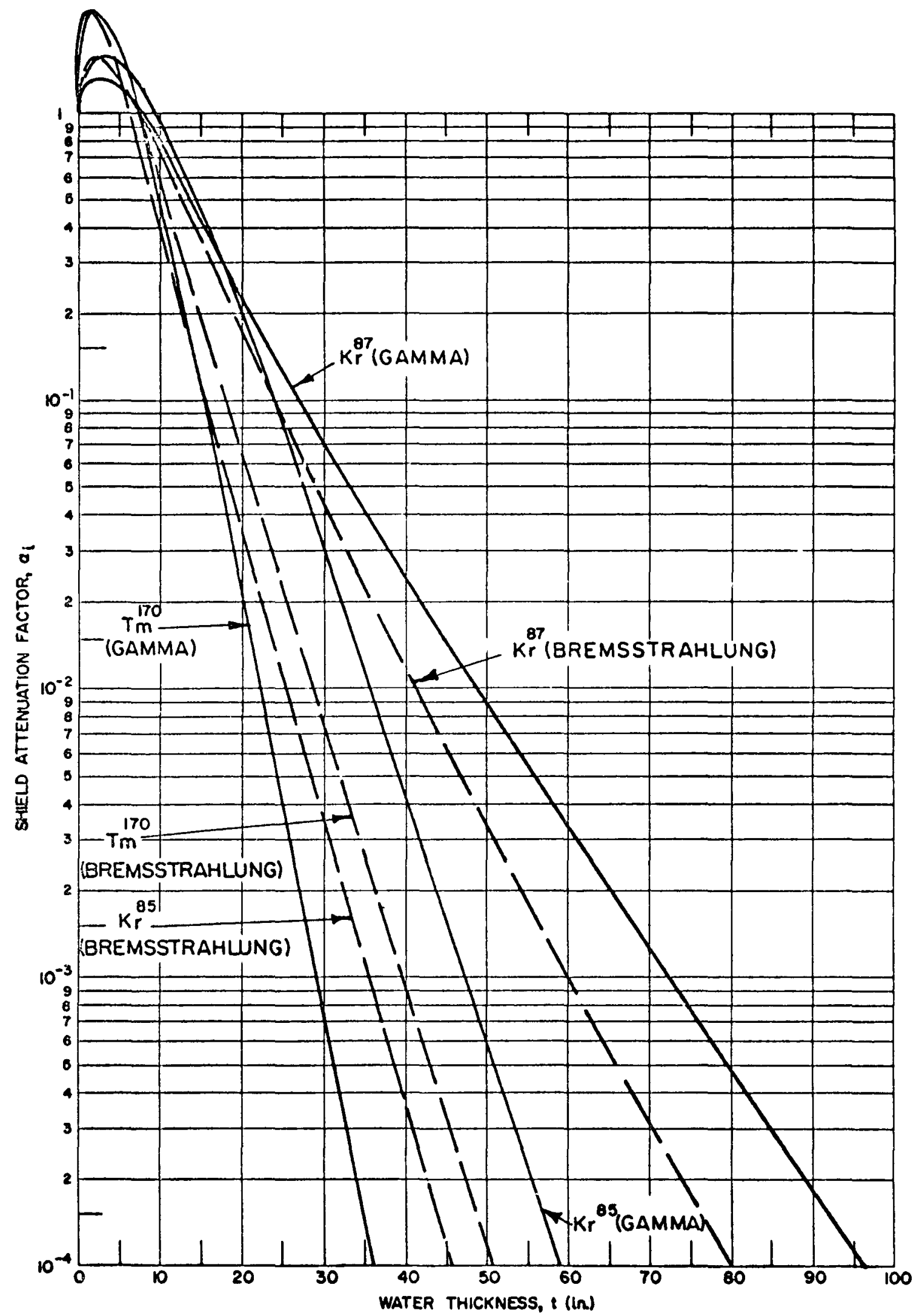

FIGURE $3 B$ 


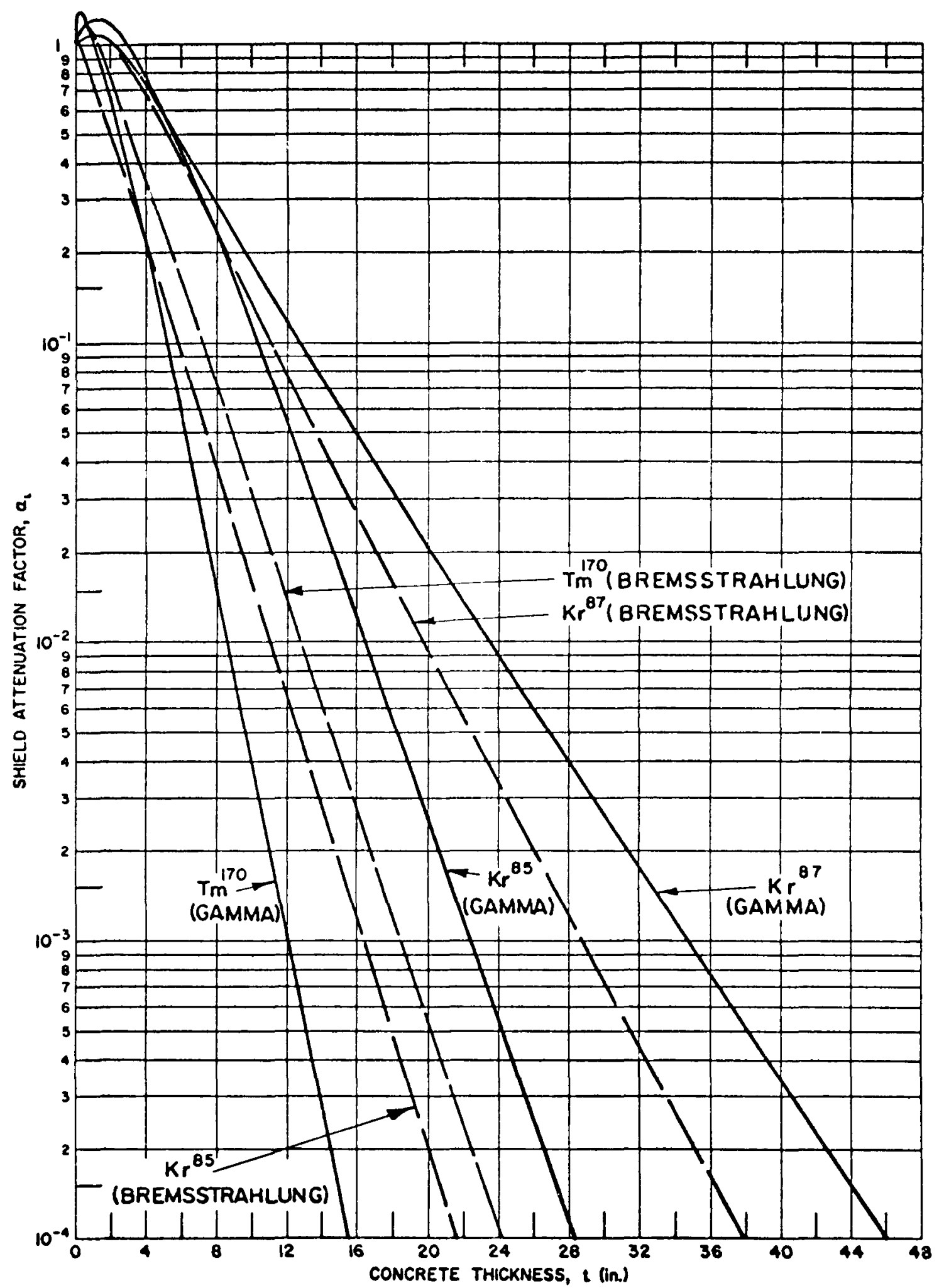

FIGURE 36 


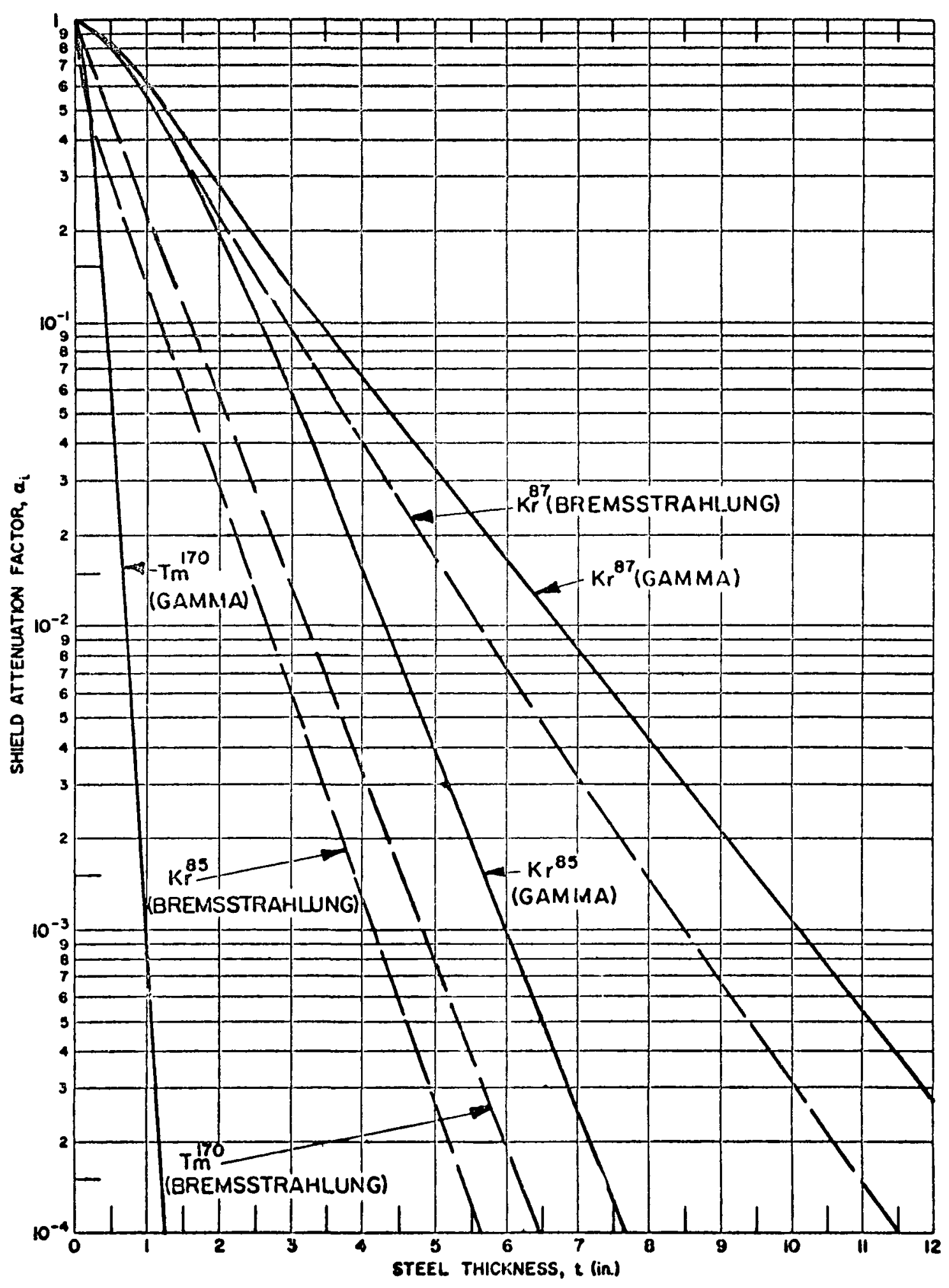

FIGURE 30 


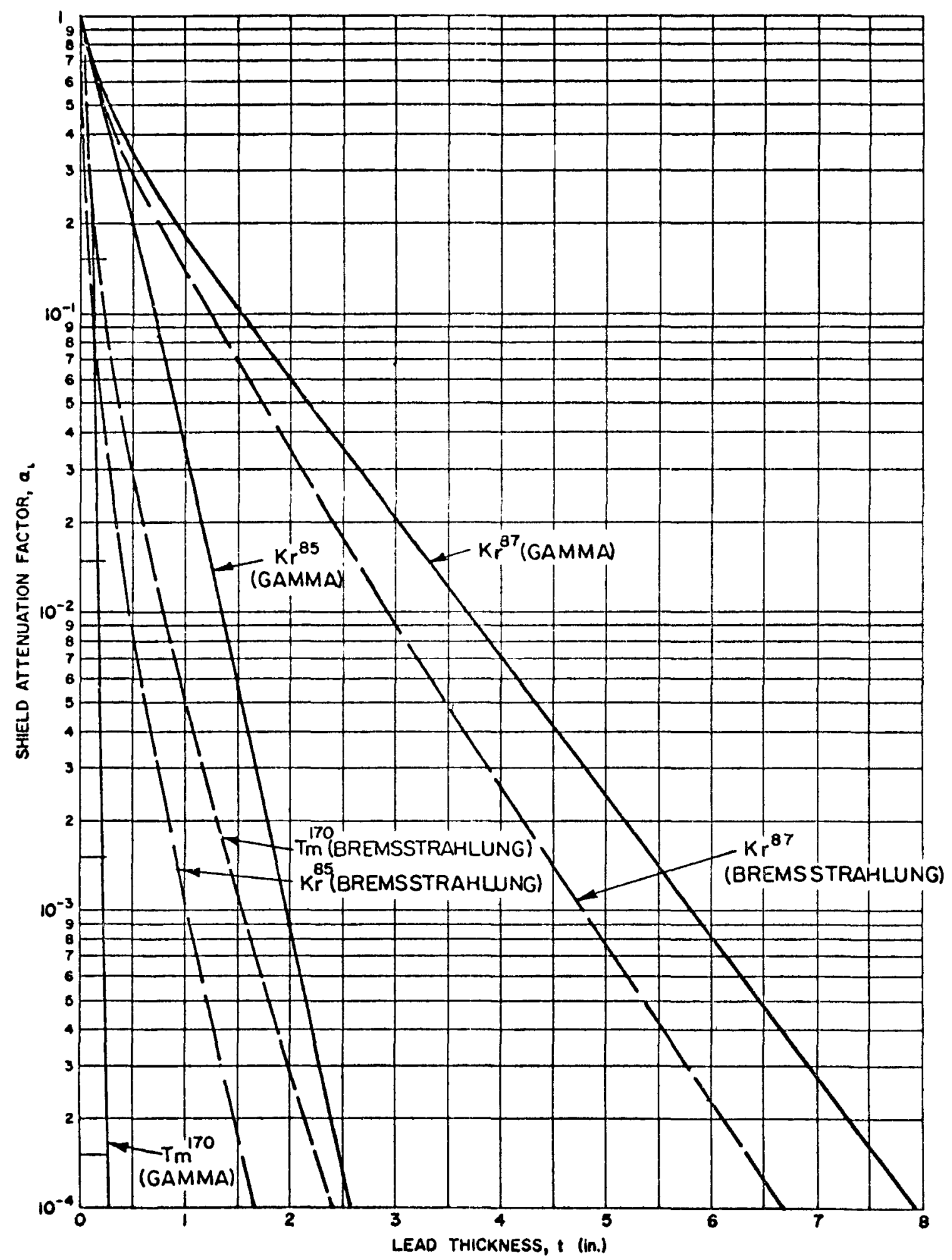

FIGURE $3 E$ 


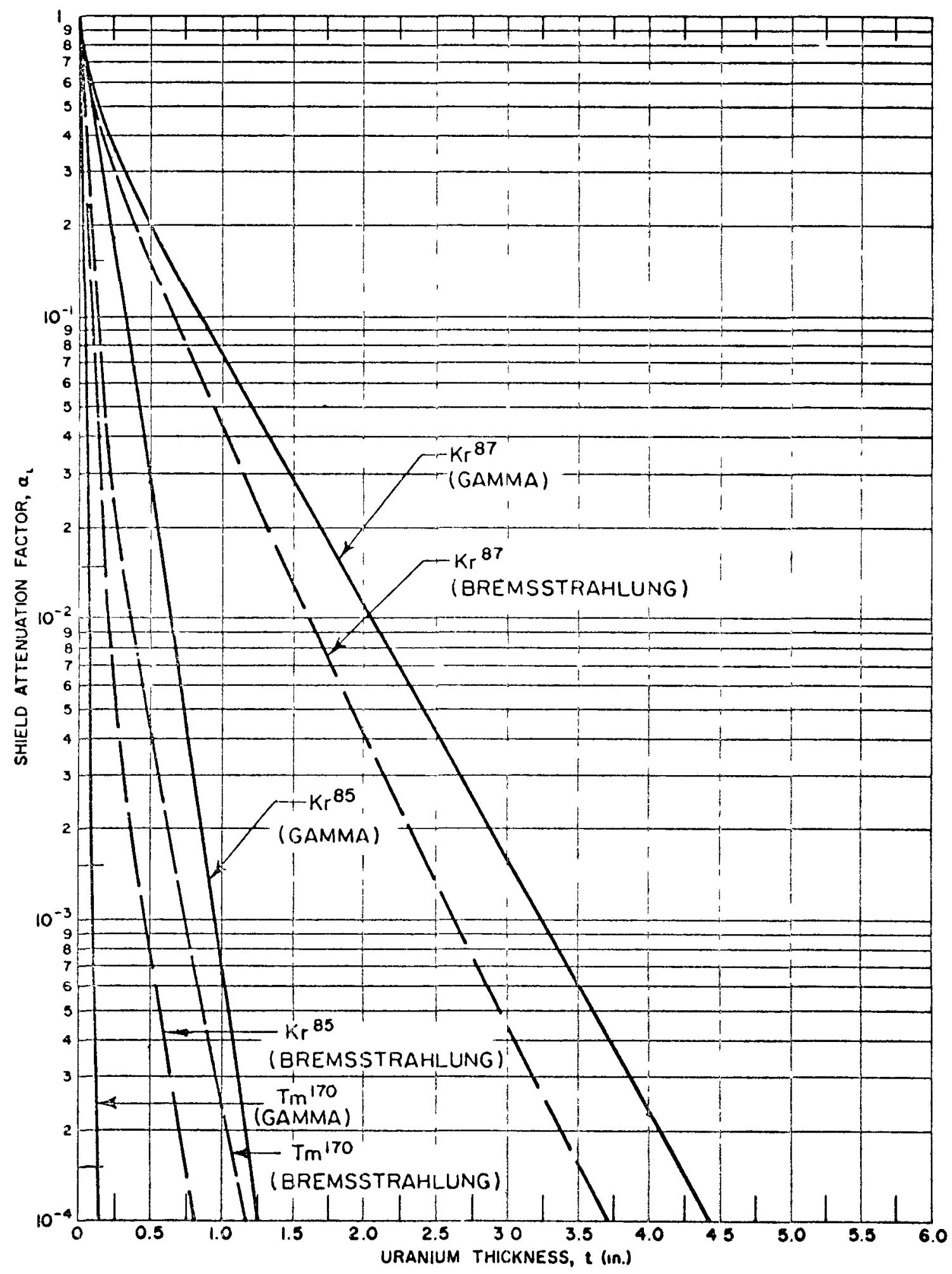

FIGURE $3 F$ 


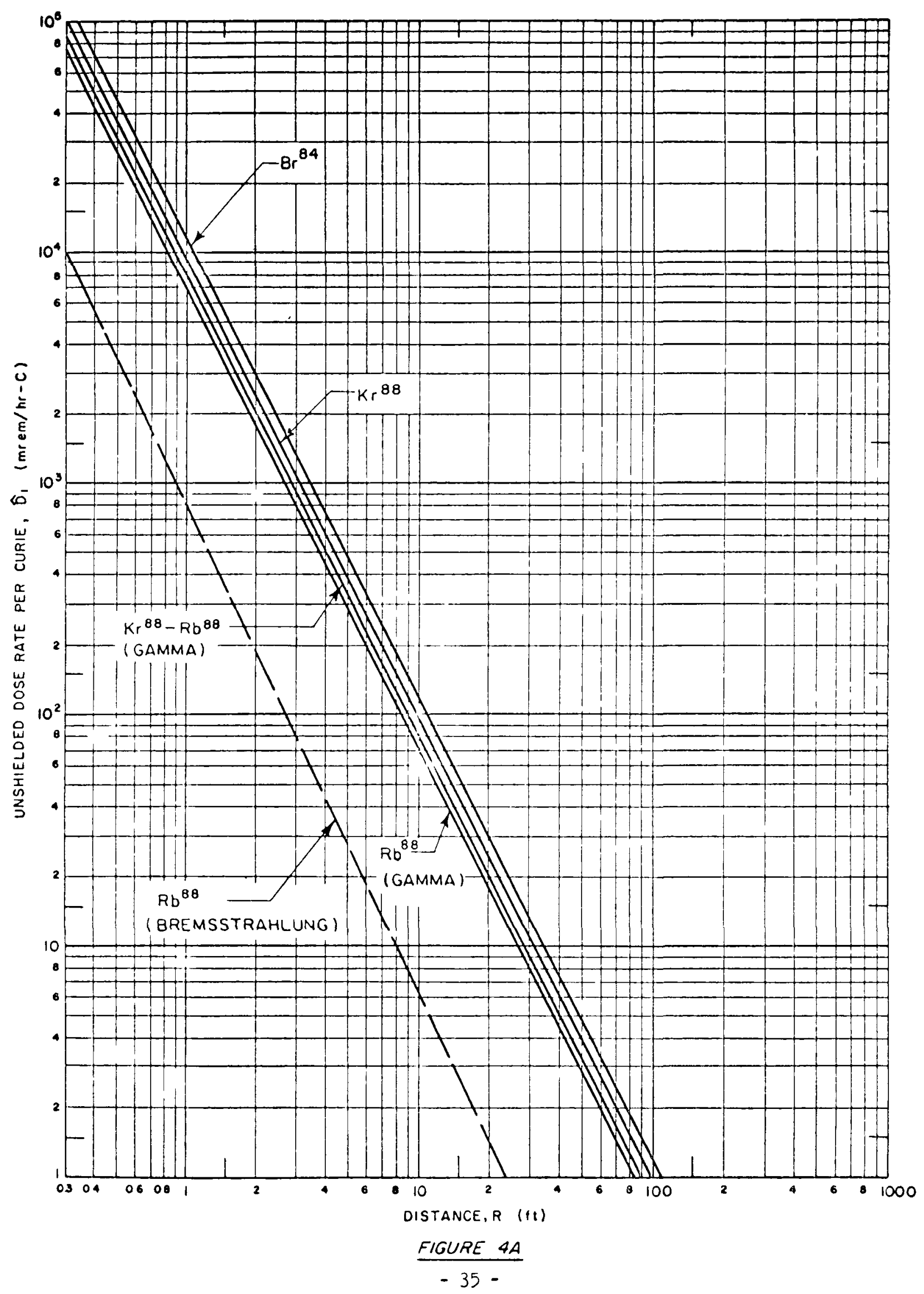




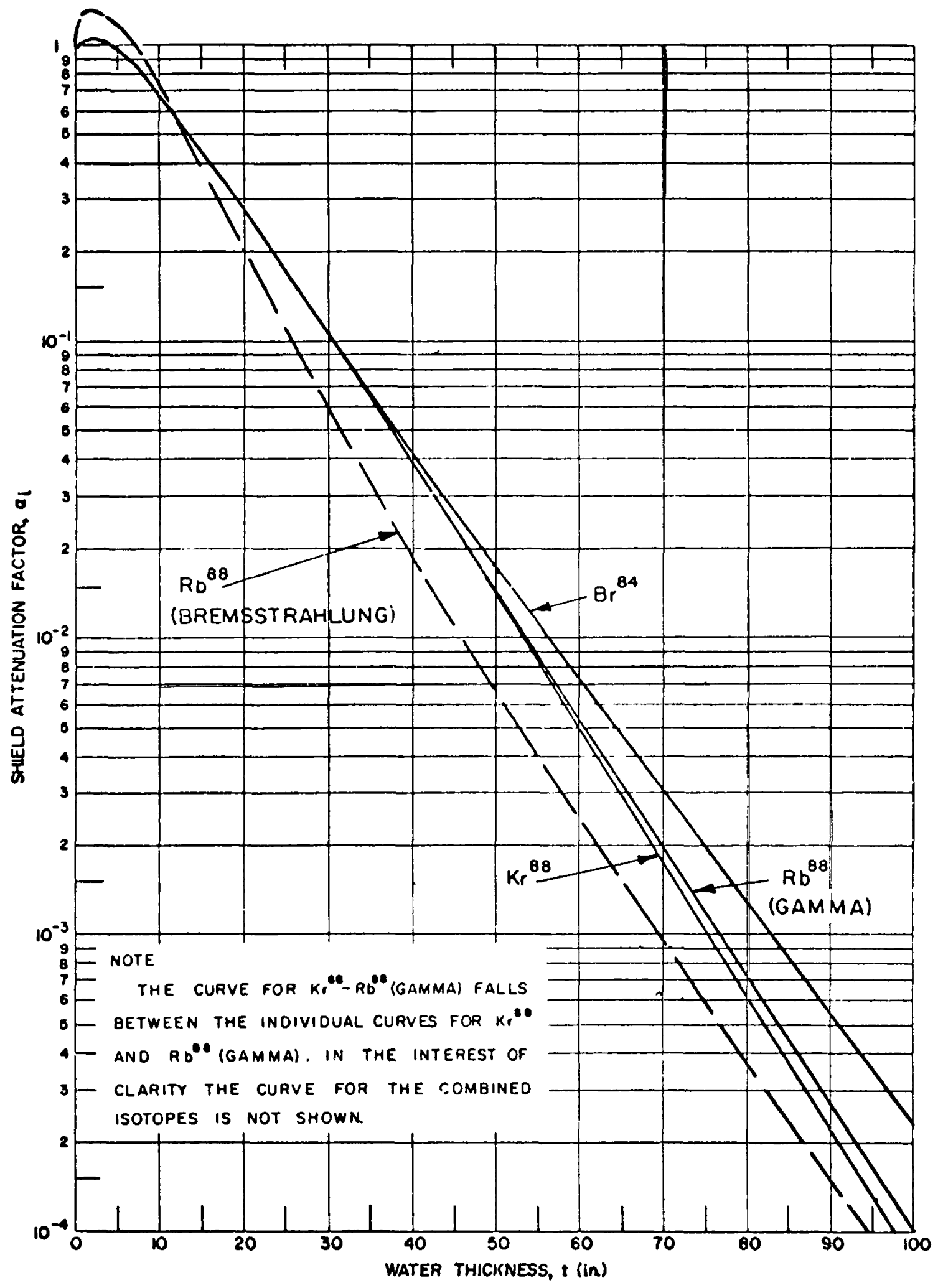

FIGURE $4 B$ 


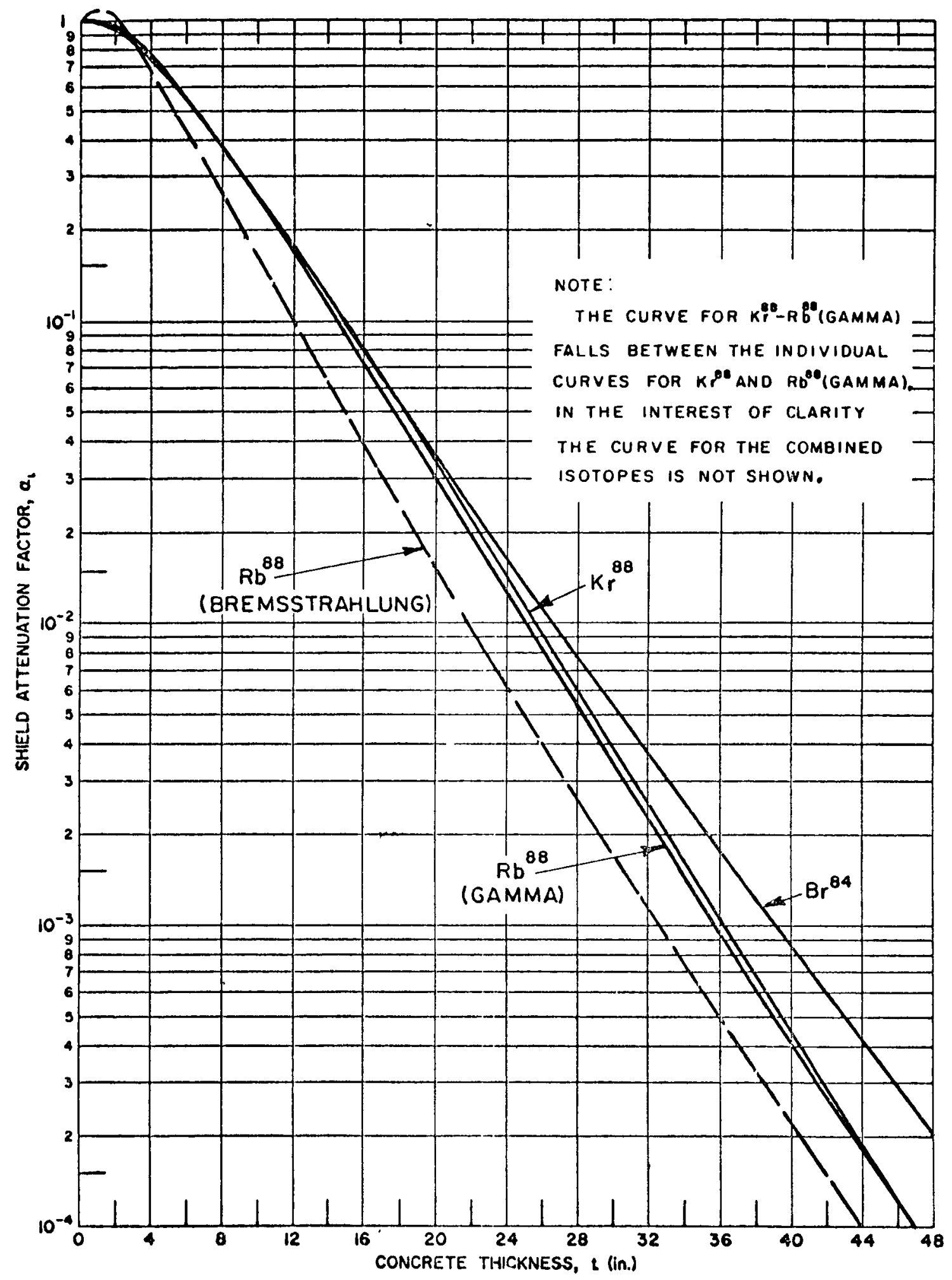

FIGURE $4 C$ 


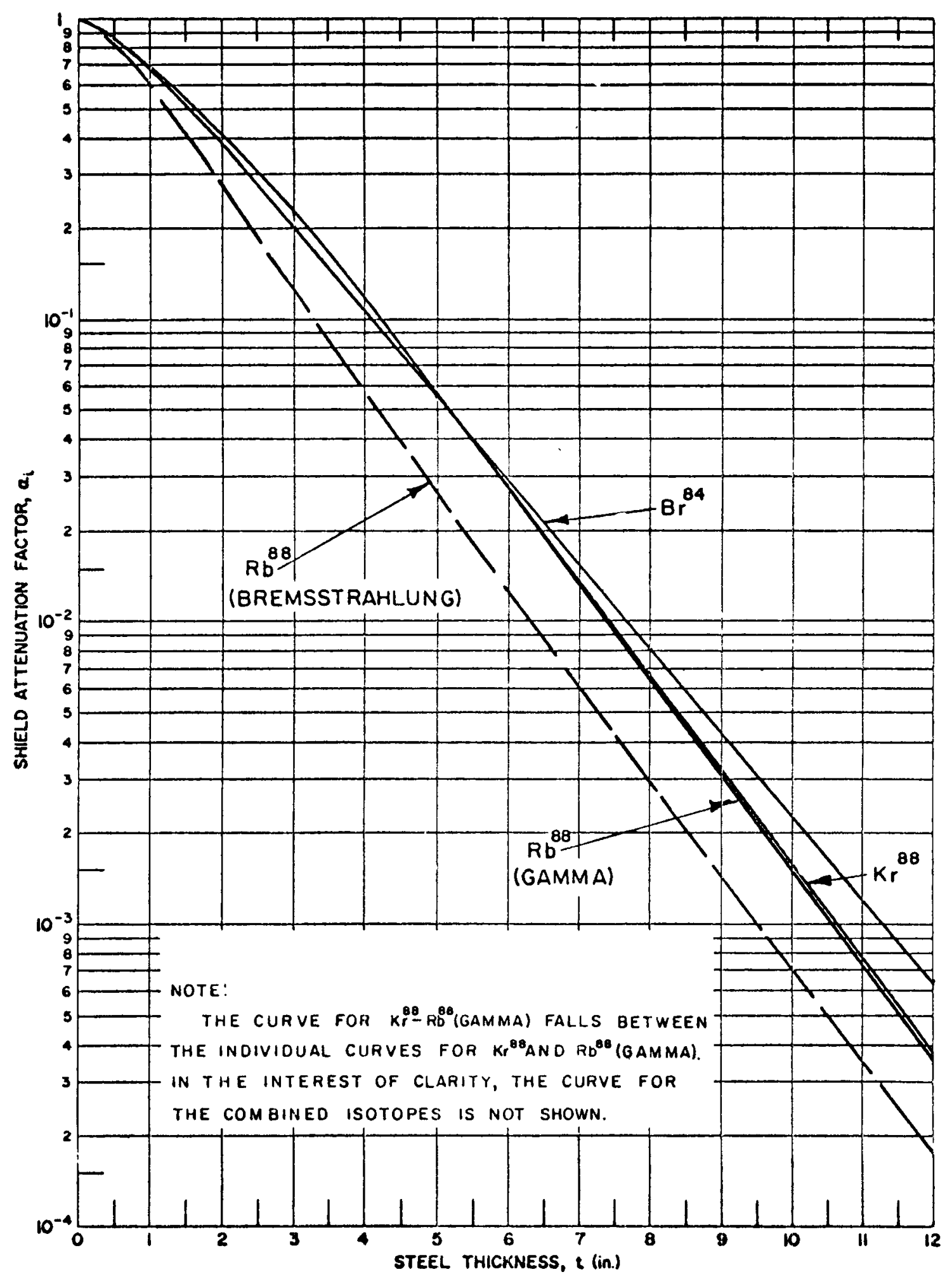

FIGURE 40

- 38 - 


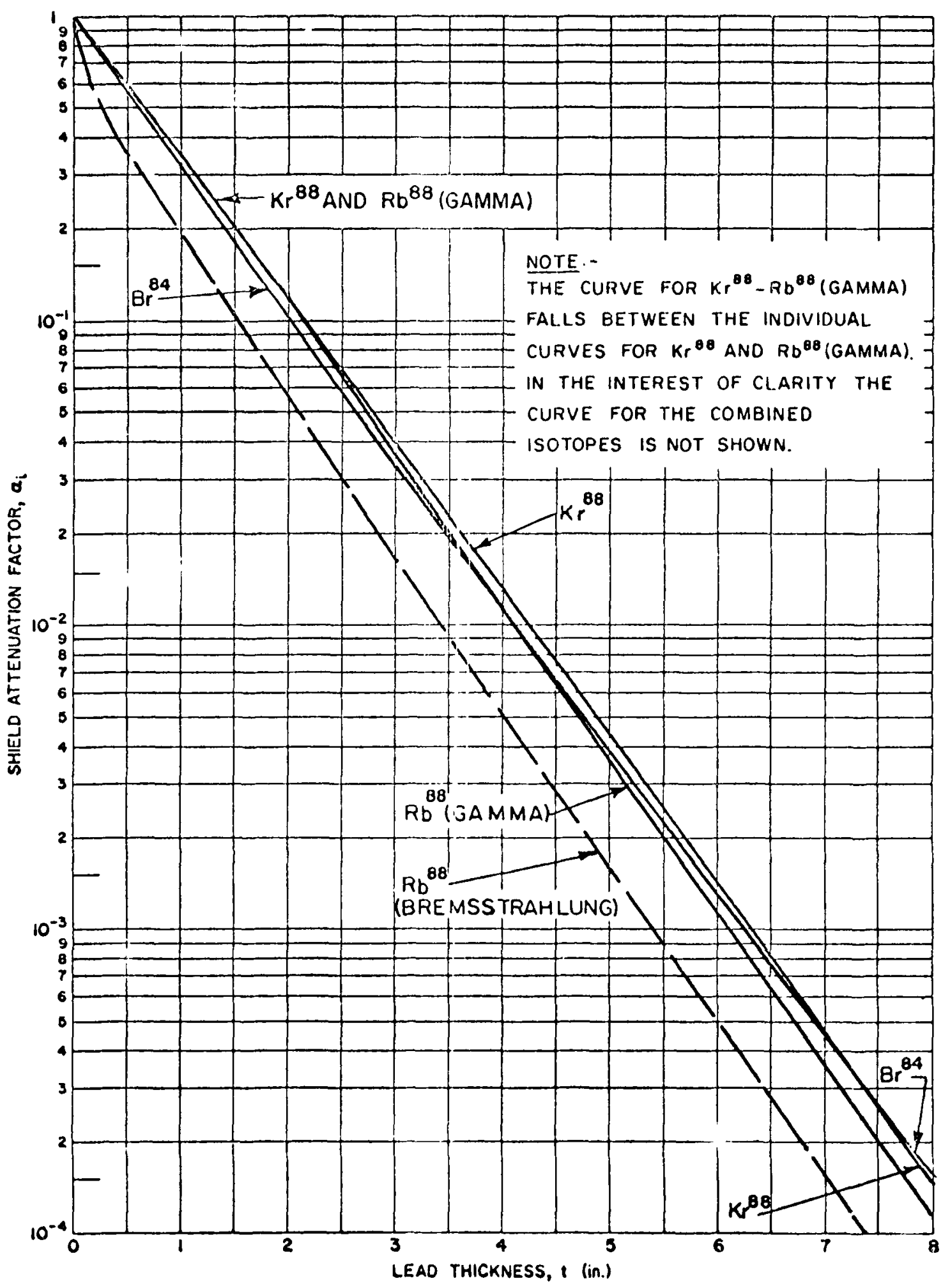

FIGURE $4 E$ 


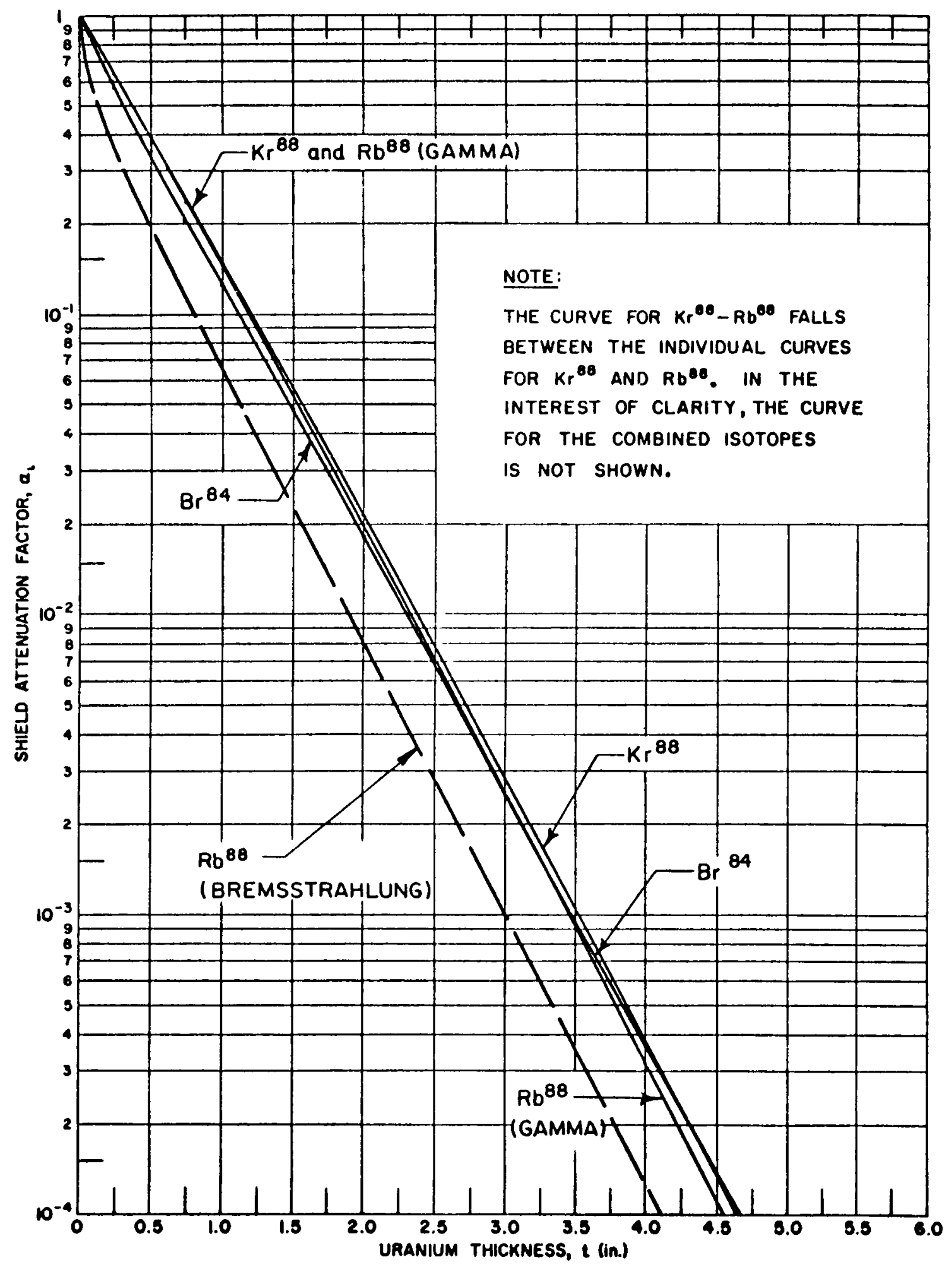

FIGURE AF 


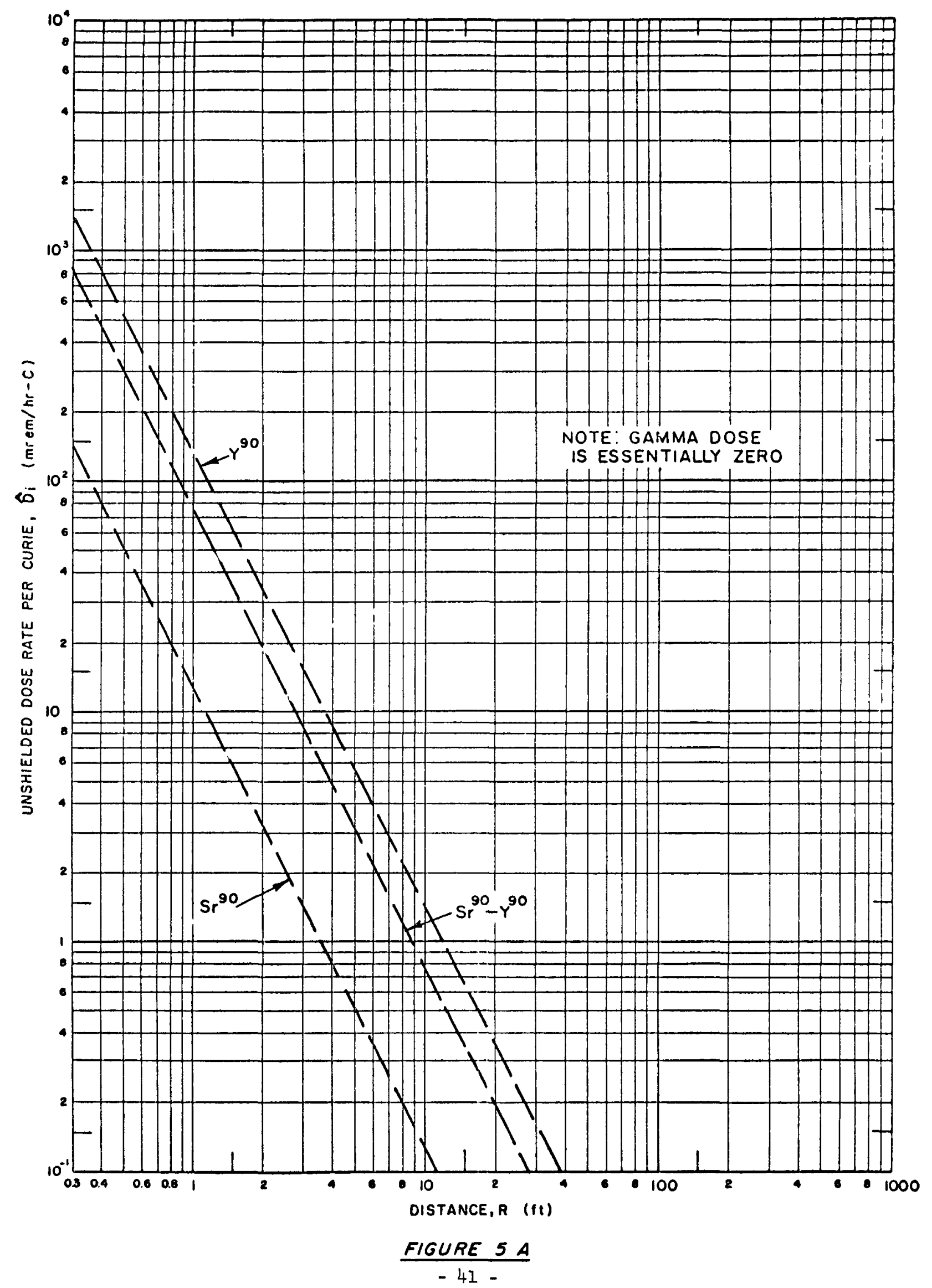




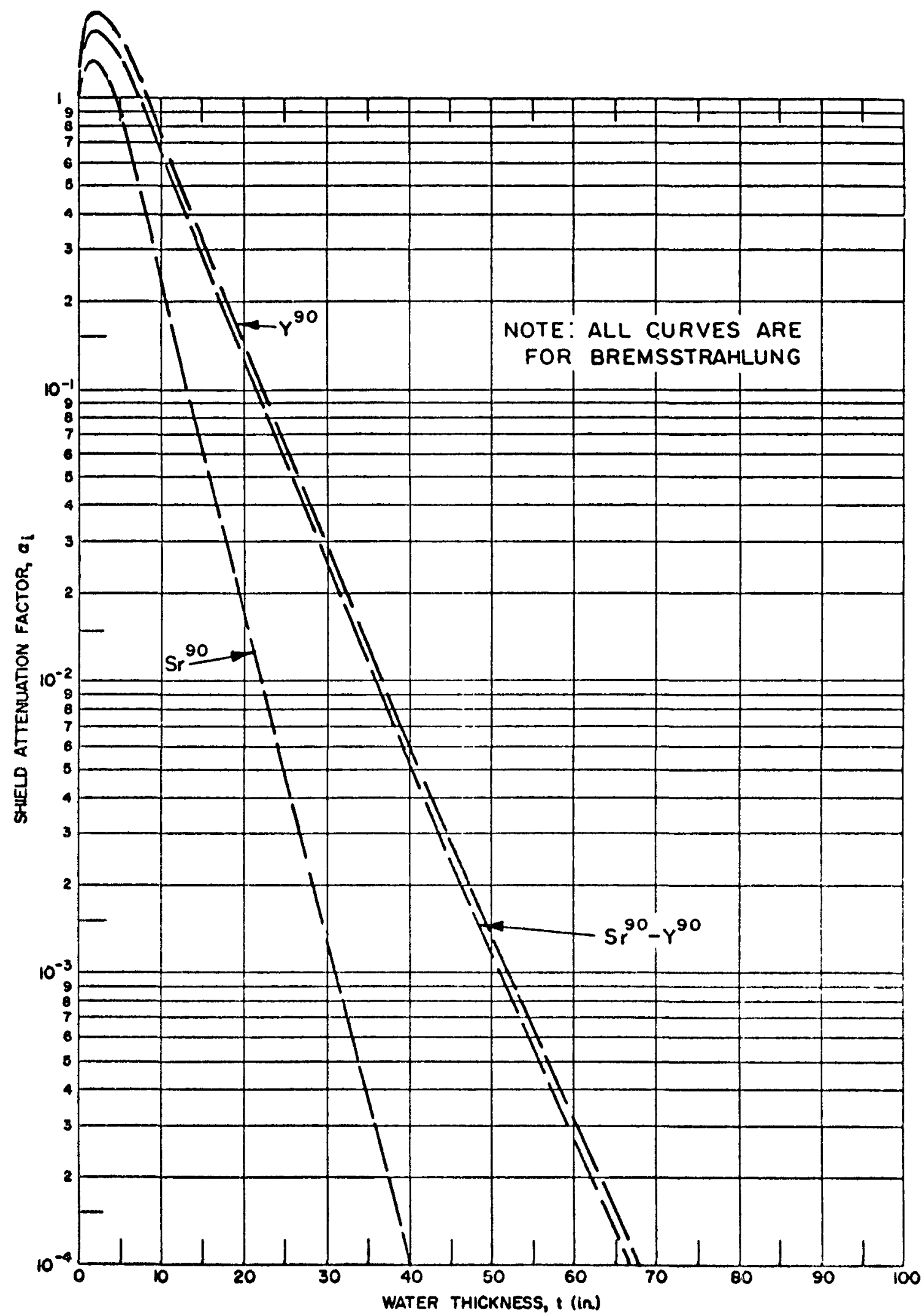

FIGURE $5 B$ 


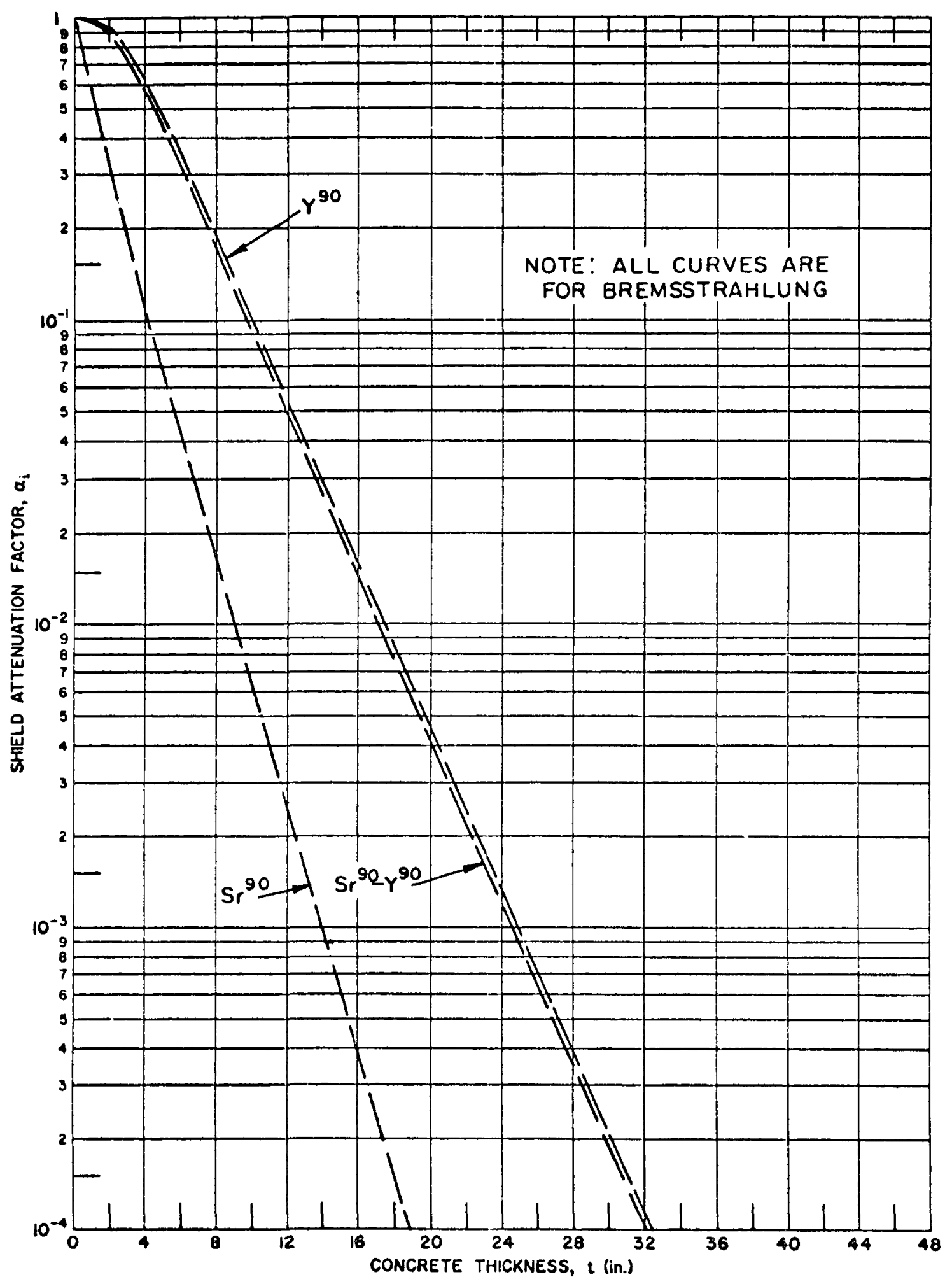

FIGURE $5 C$ 


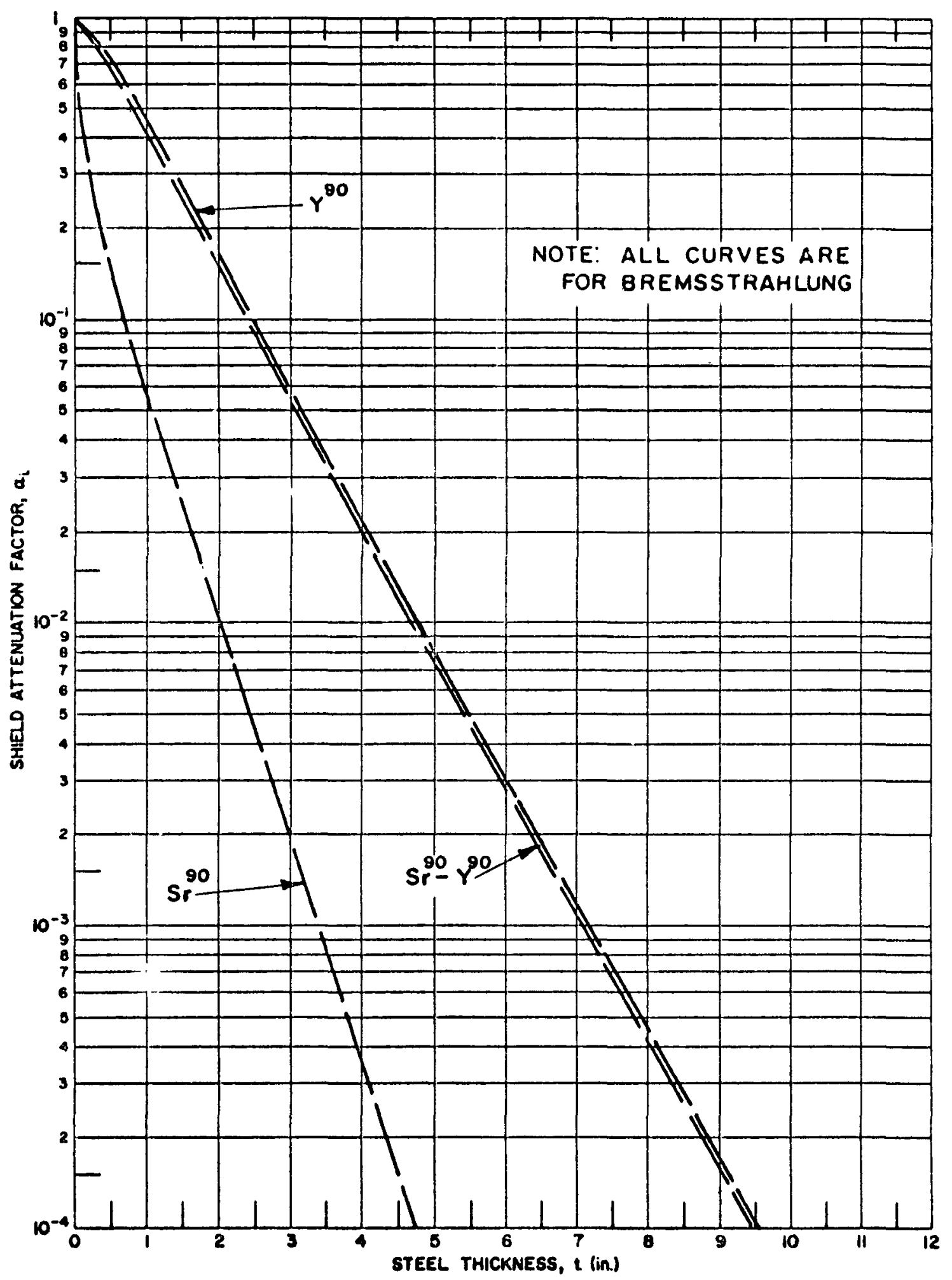

FIGURE 50 


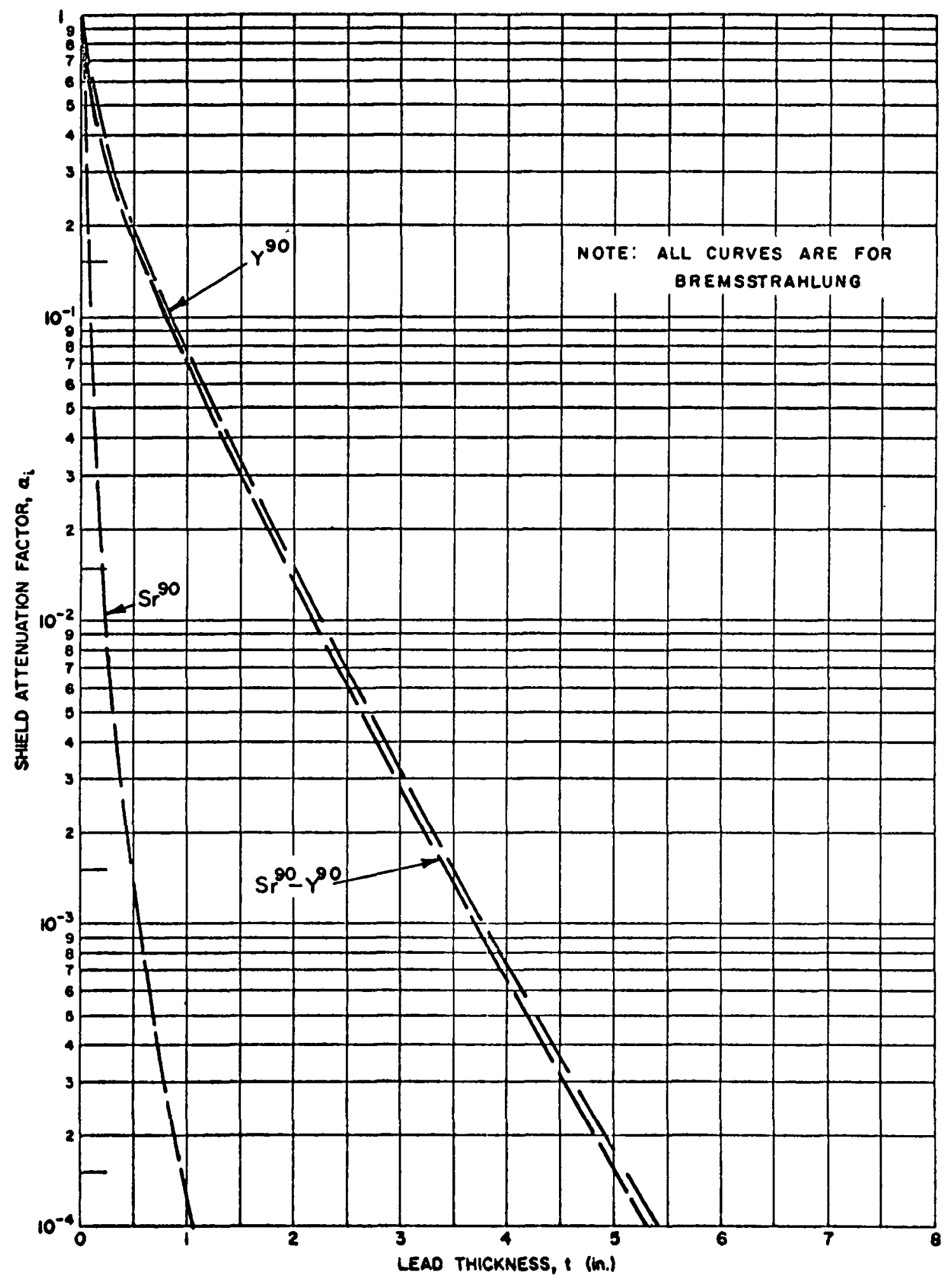

FIGURE $5 E$ 


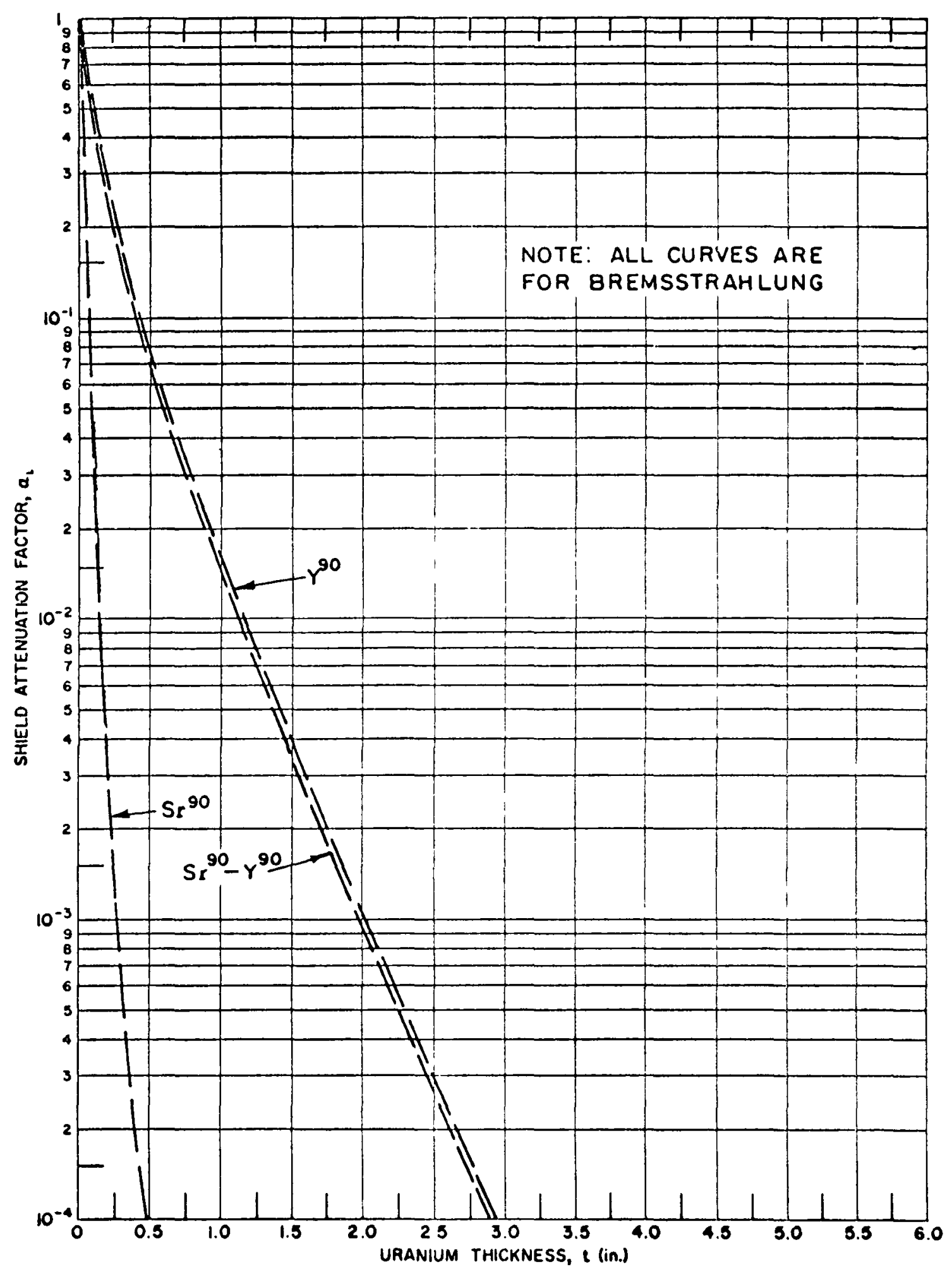

FIGURE $5 F$

- 46 - 


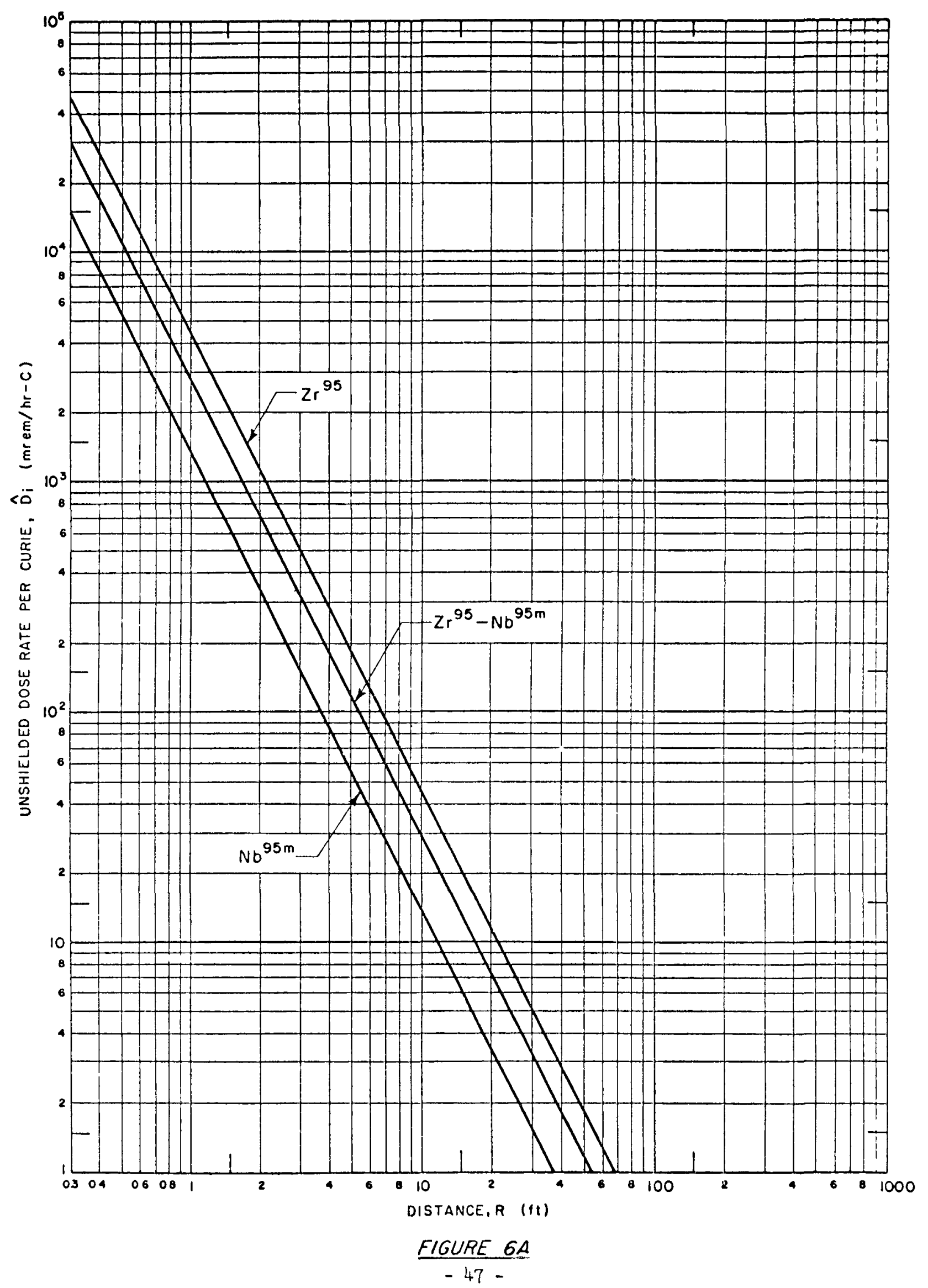




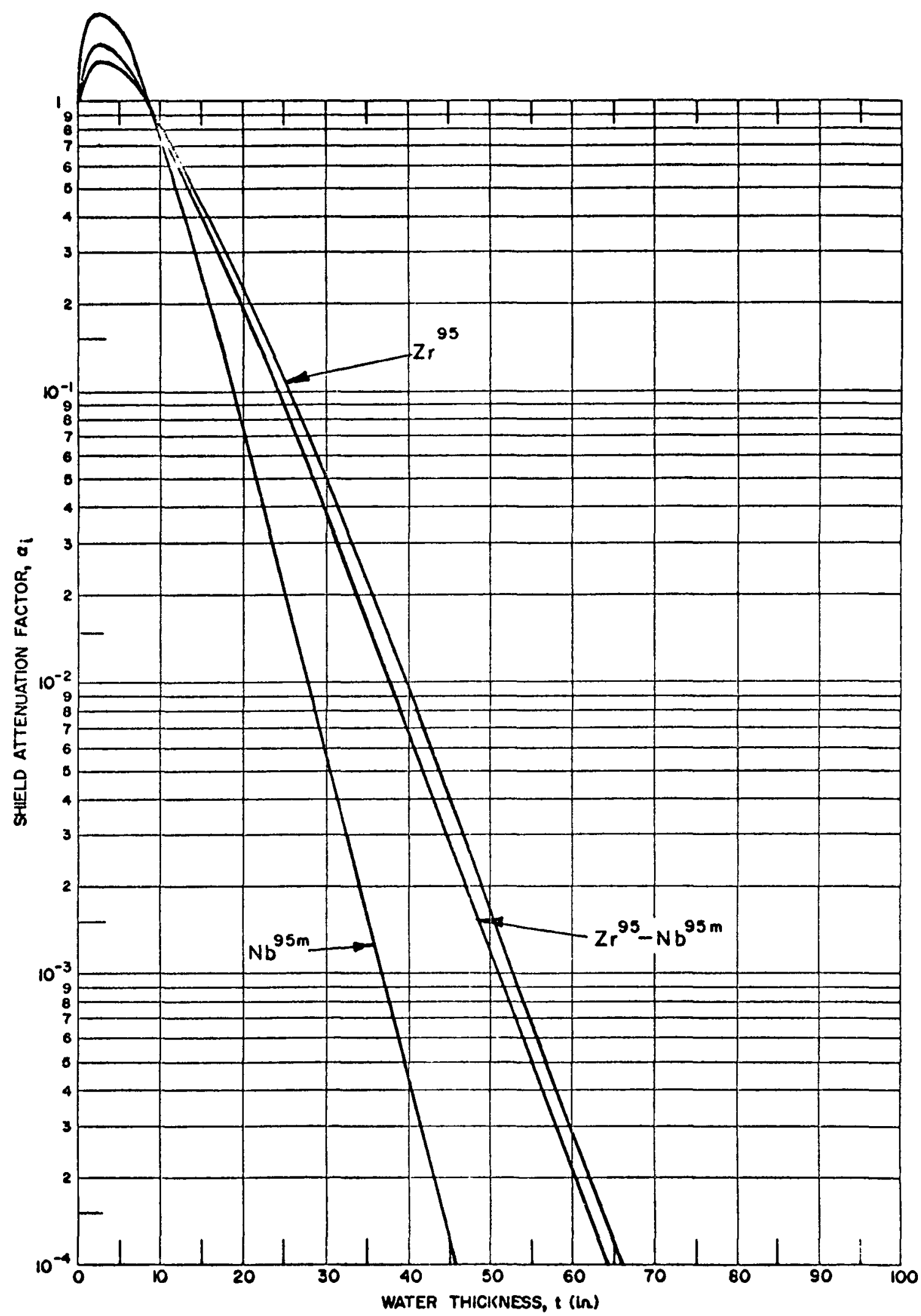

FIGURE 6B 


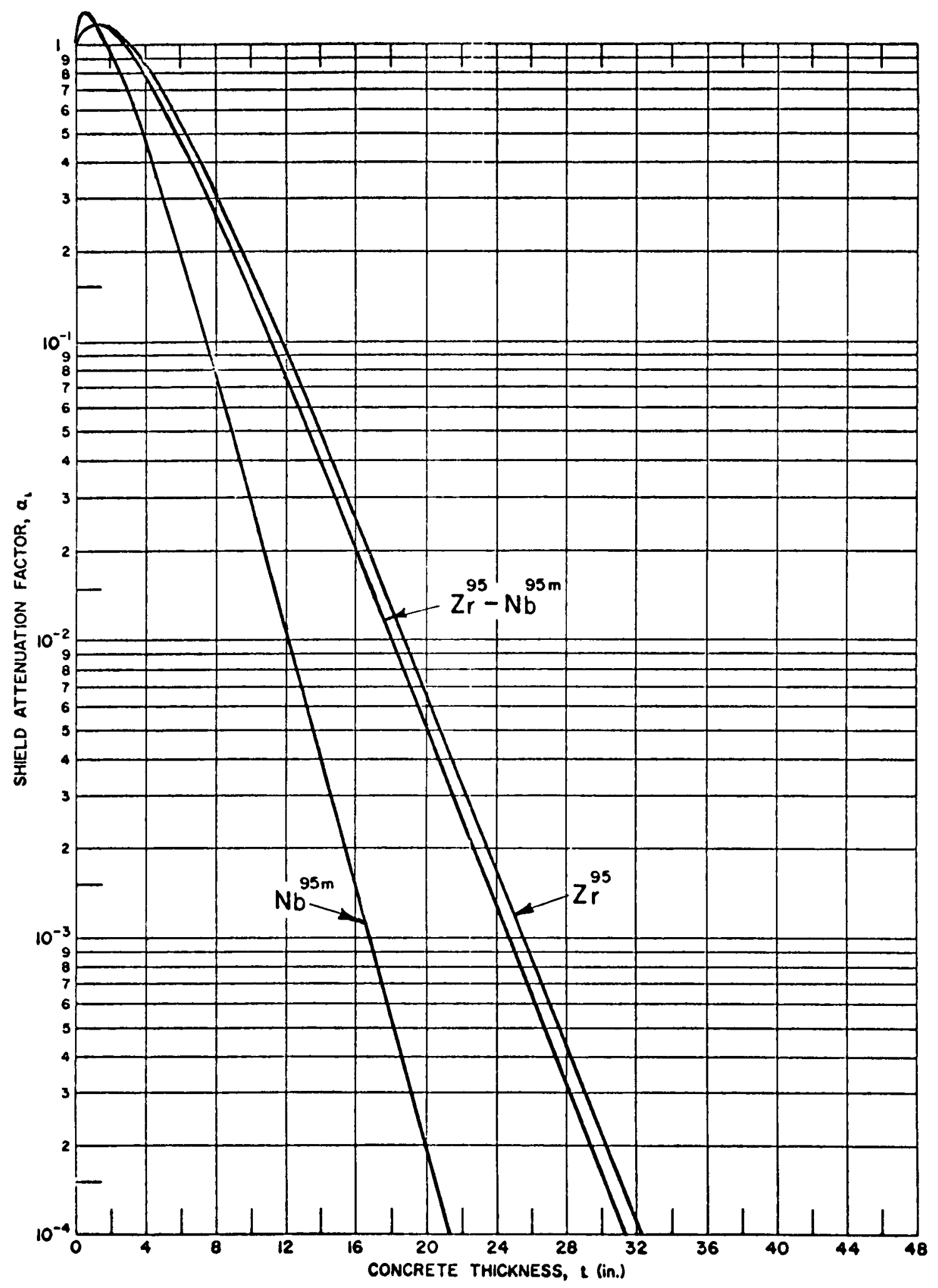

FIGURE $6 C$ 


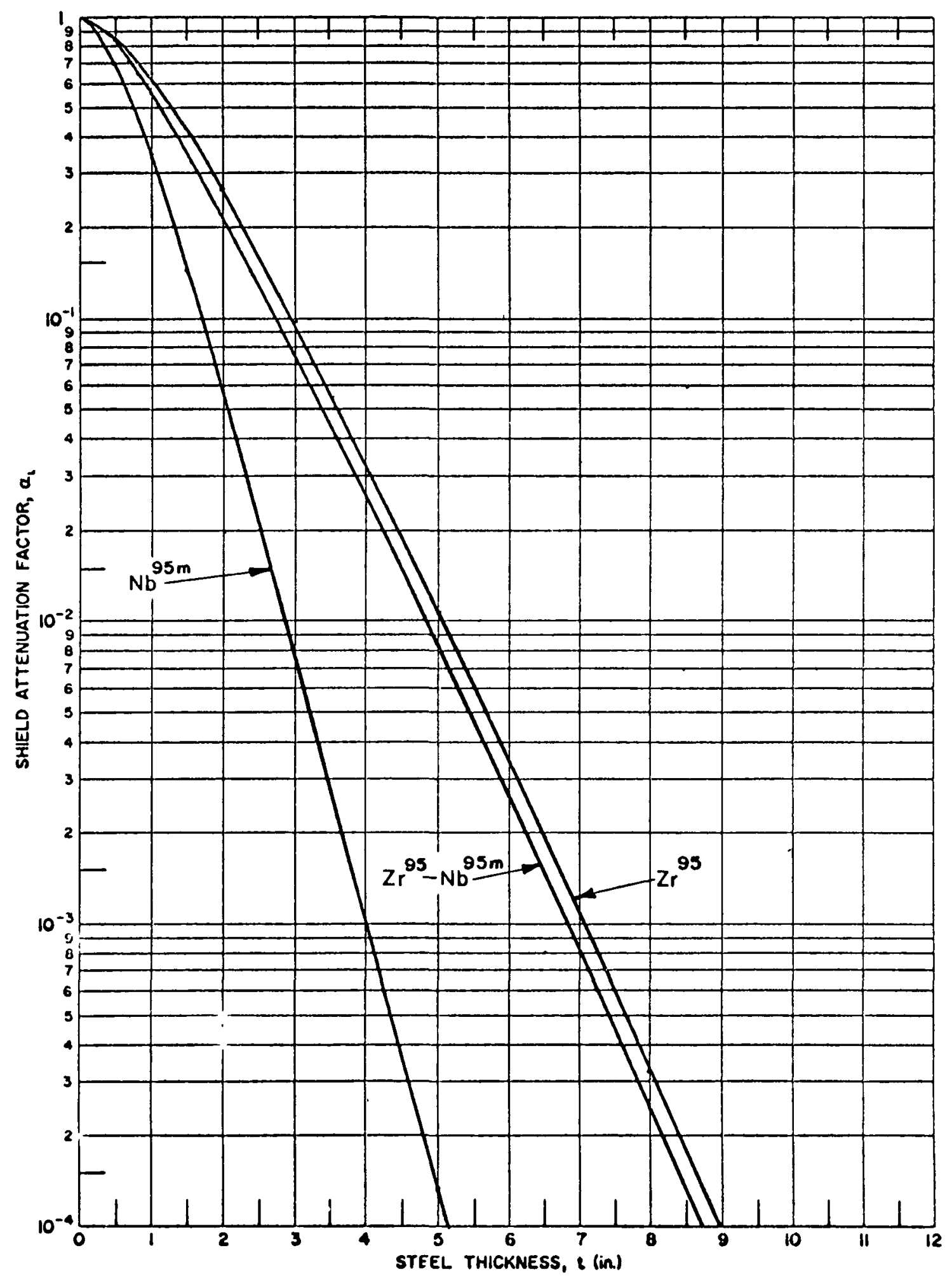

FIGURE 60 


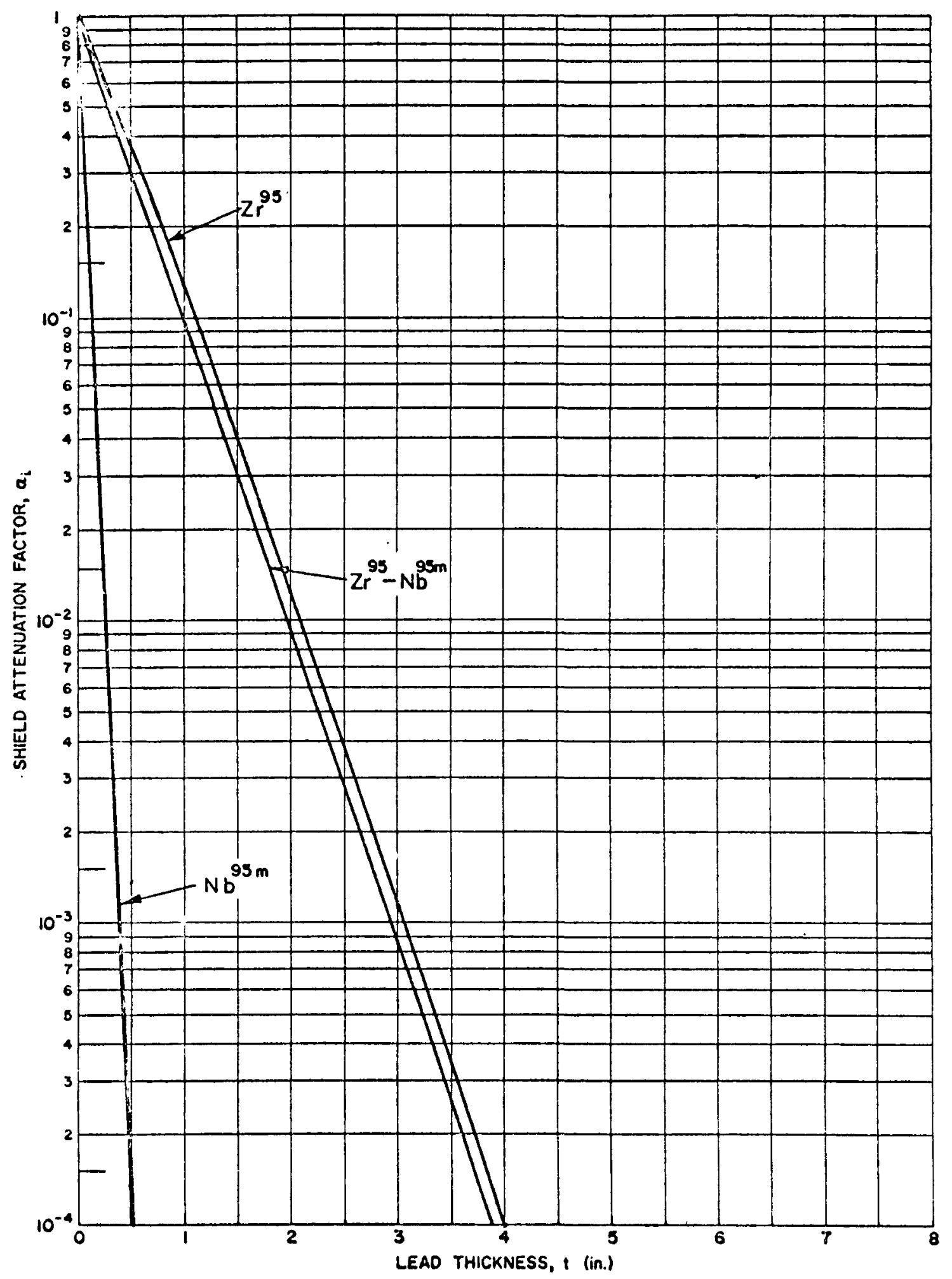

FIGURE $6 E$ 


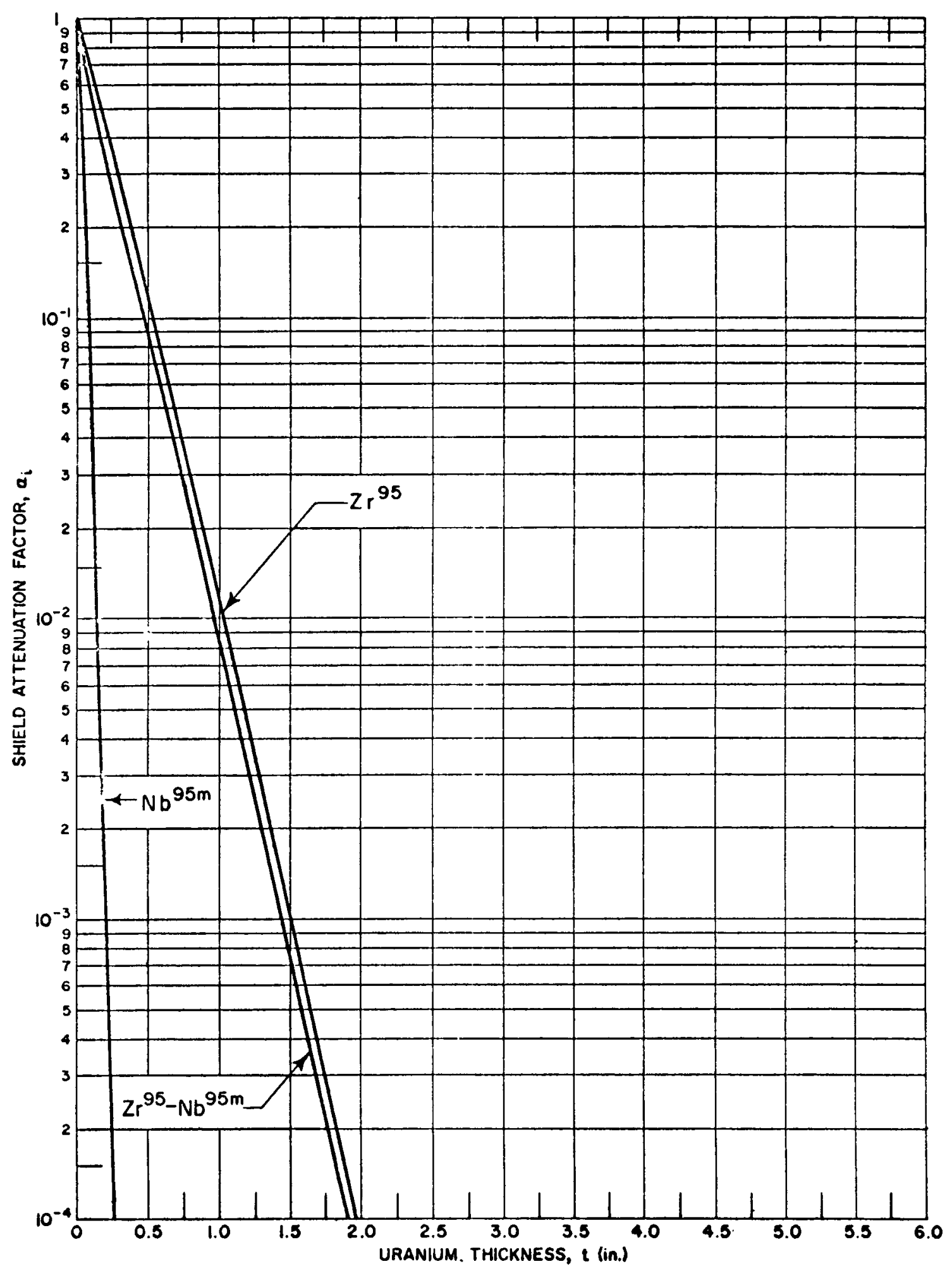

FIGURE GF 


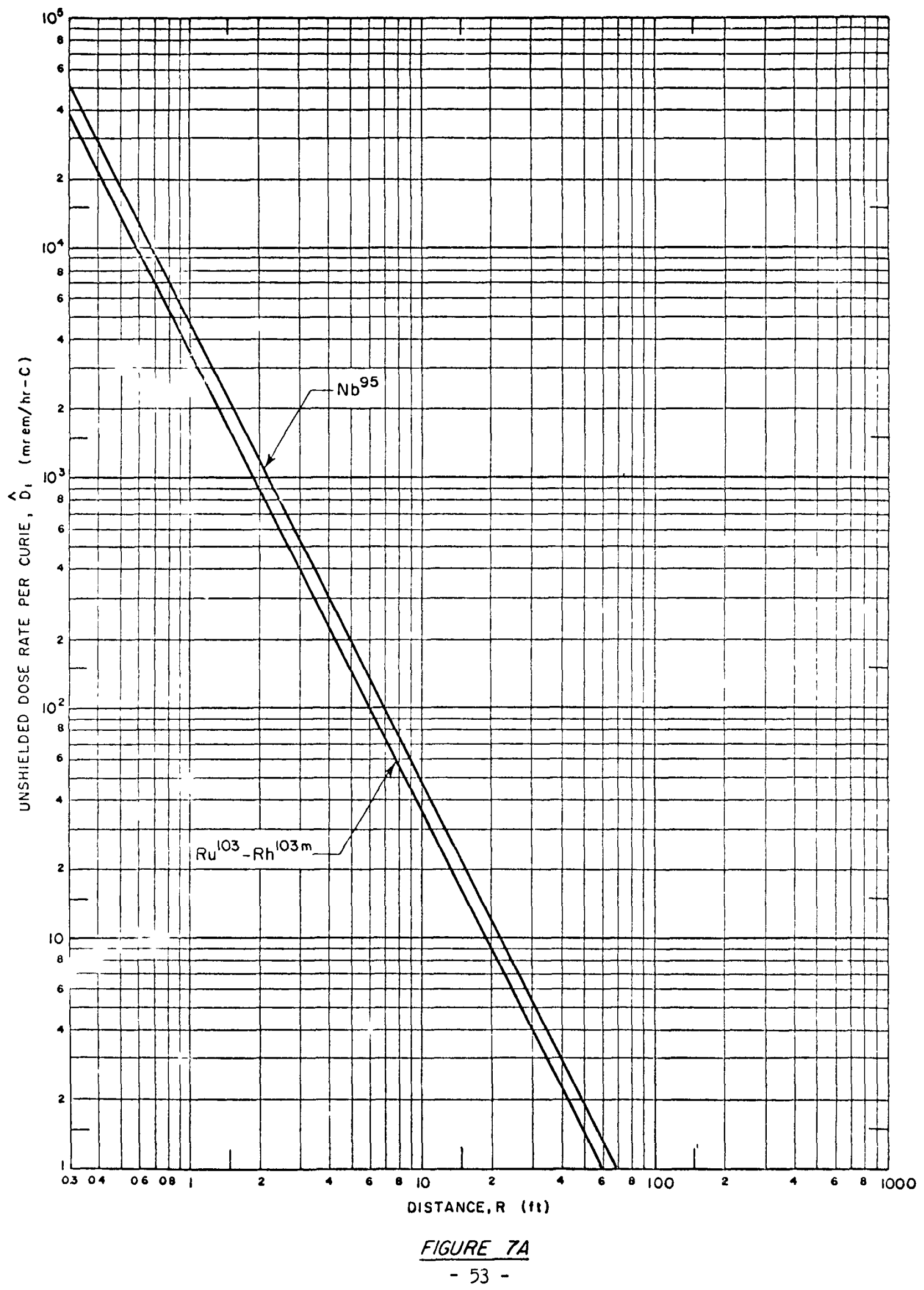




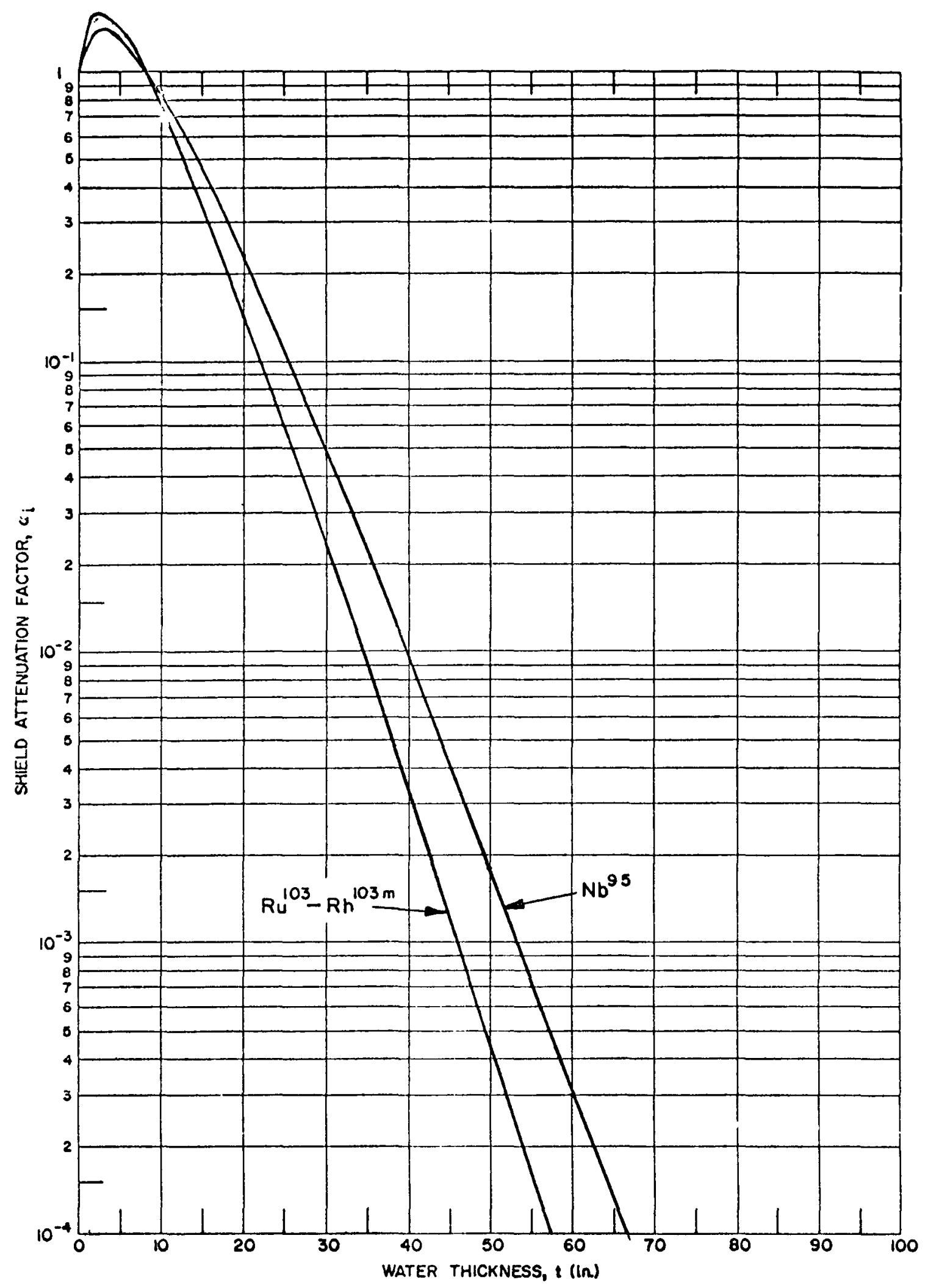

FIGURE 78 


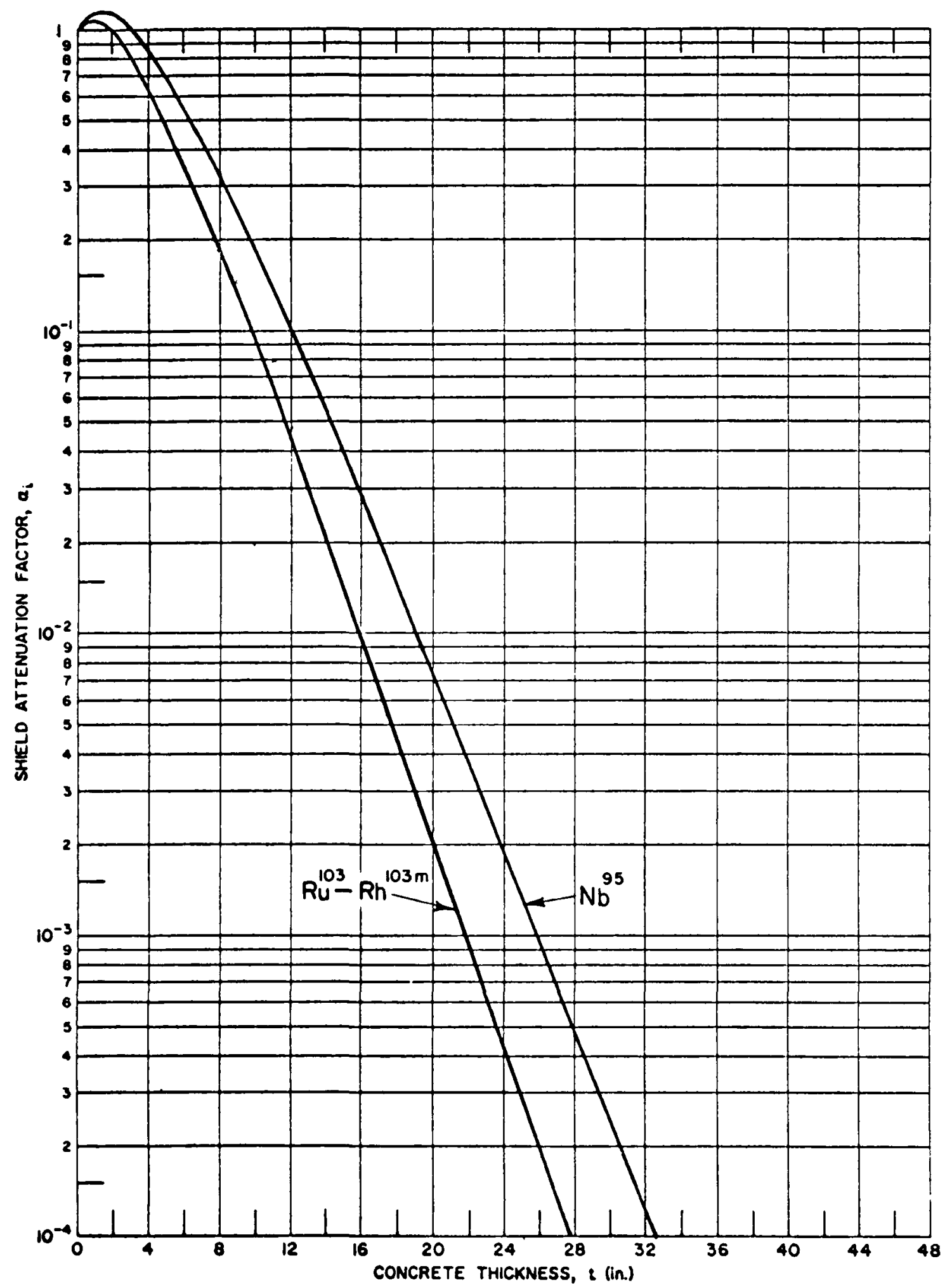

FIGURE $7 C$ 


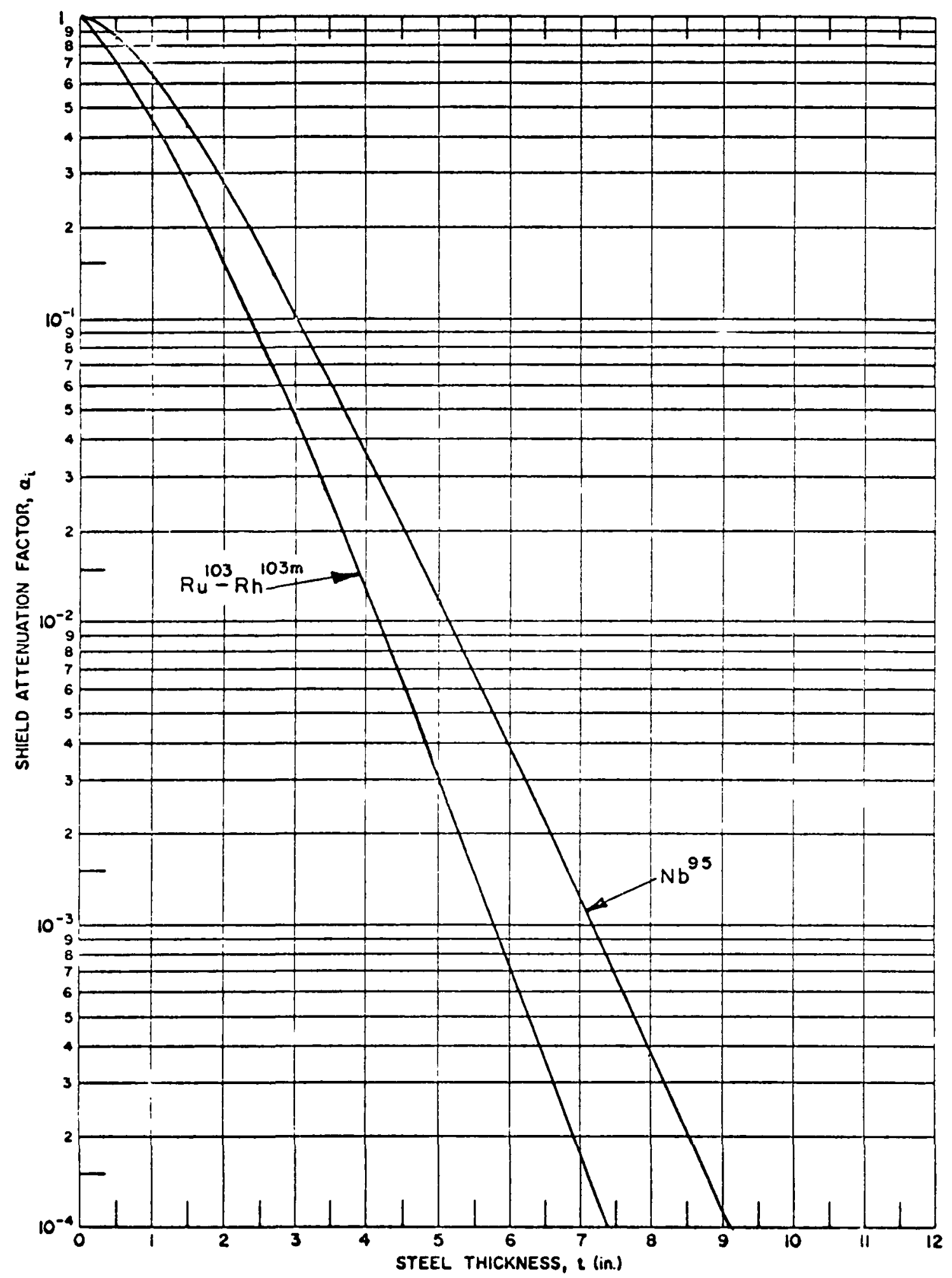

FIGURE TD 


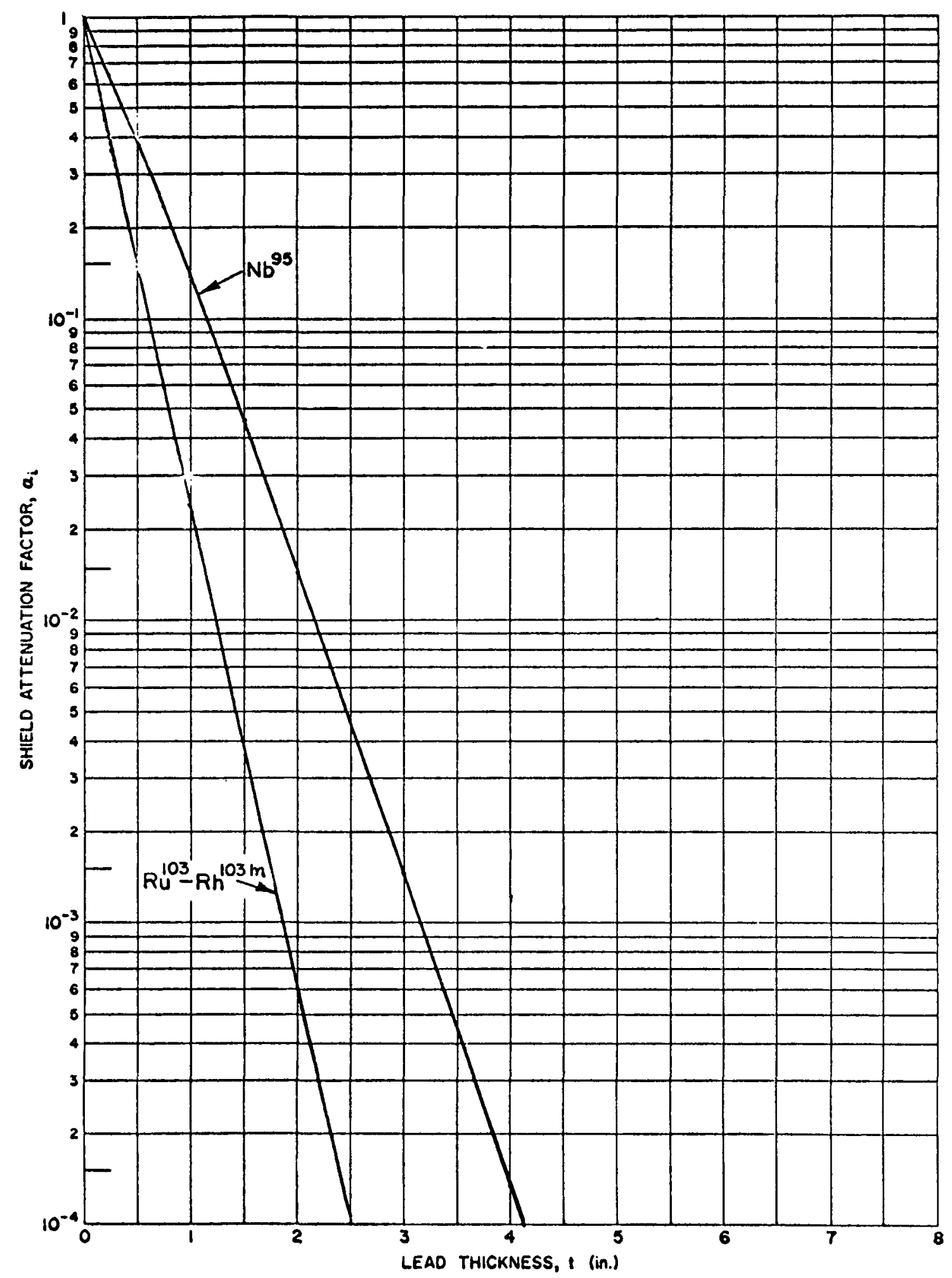

FIGURE TE 


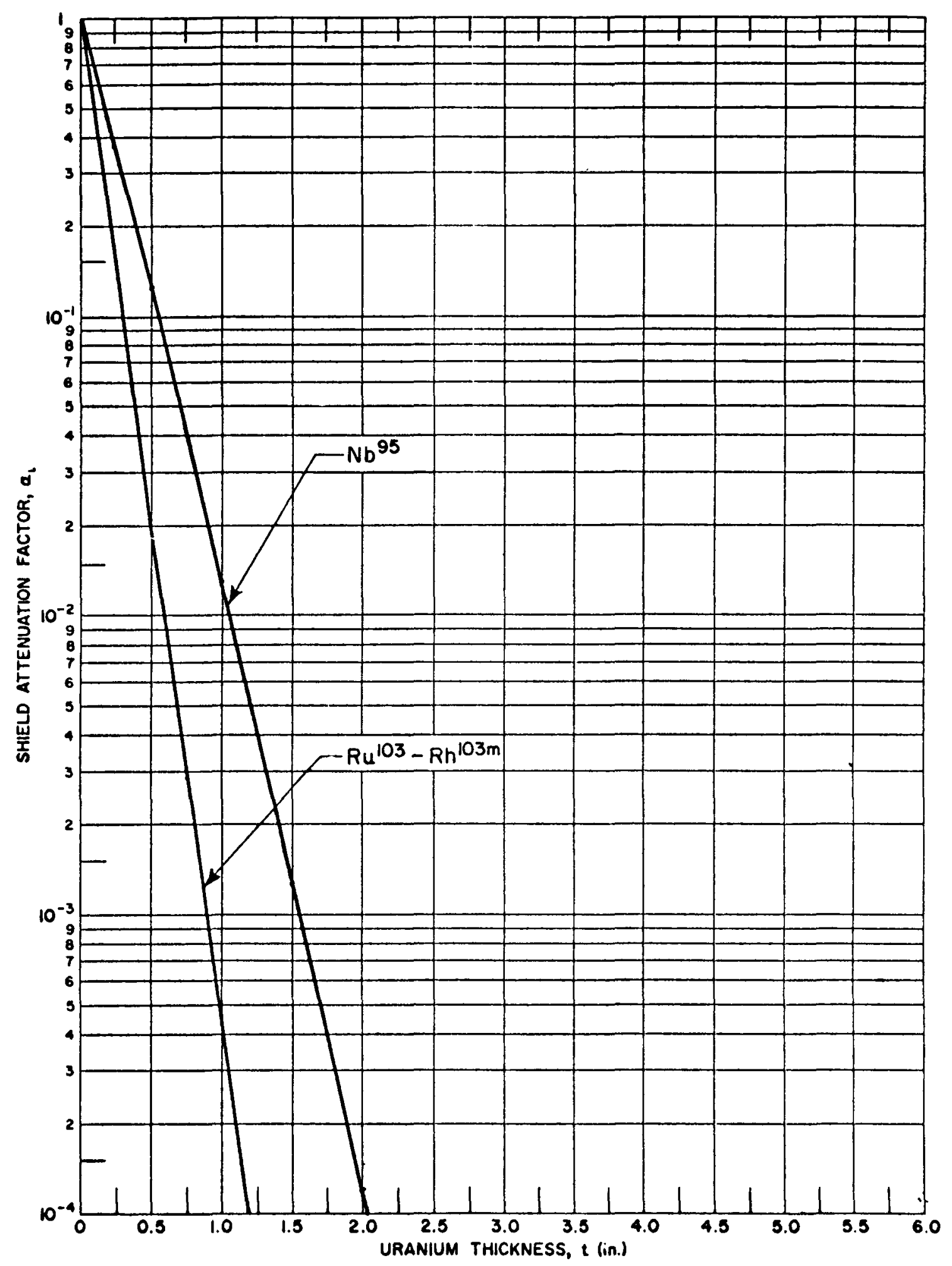

FIGURE TF 


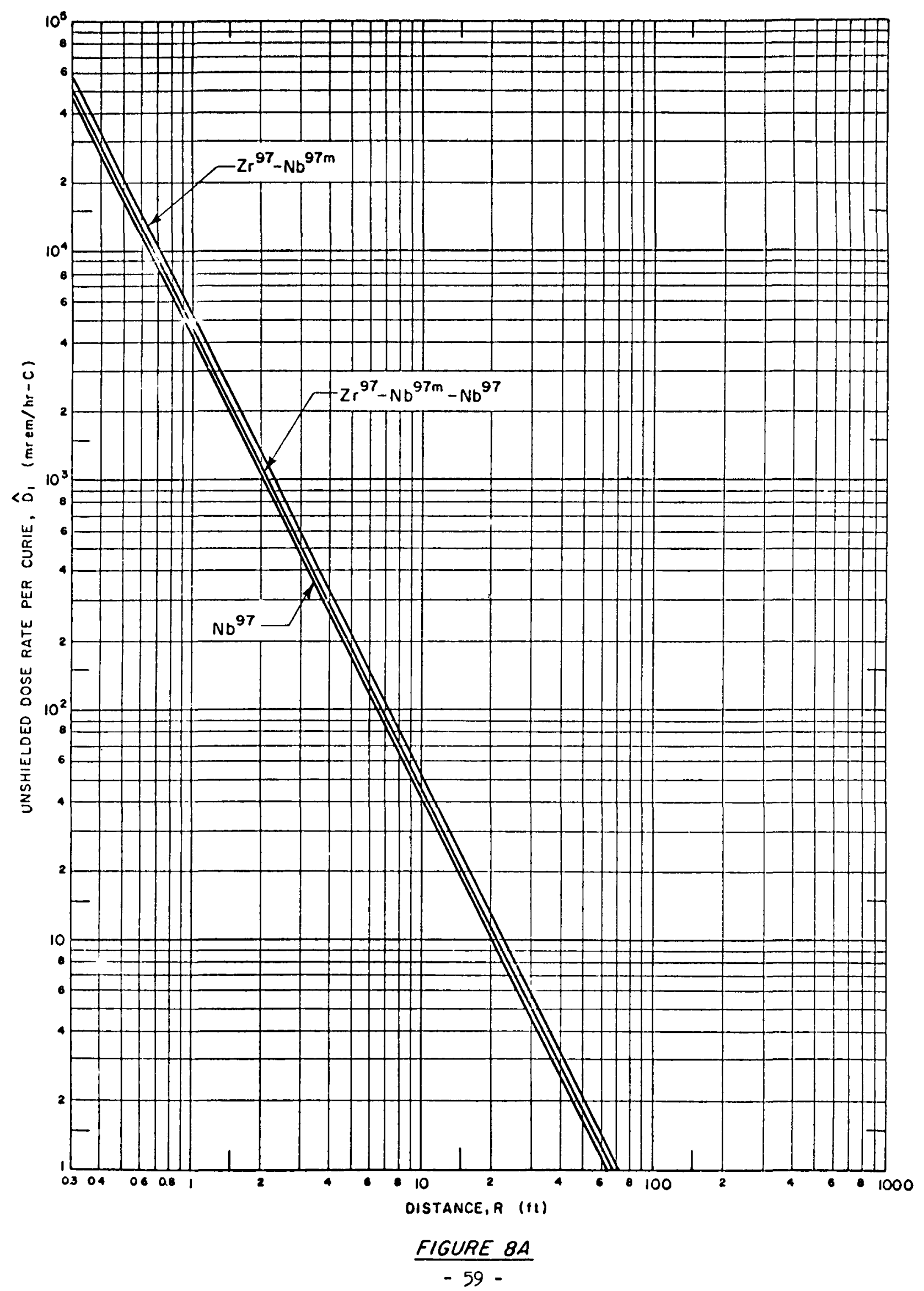




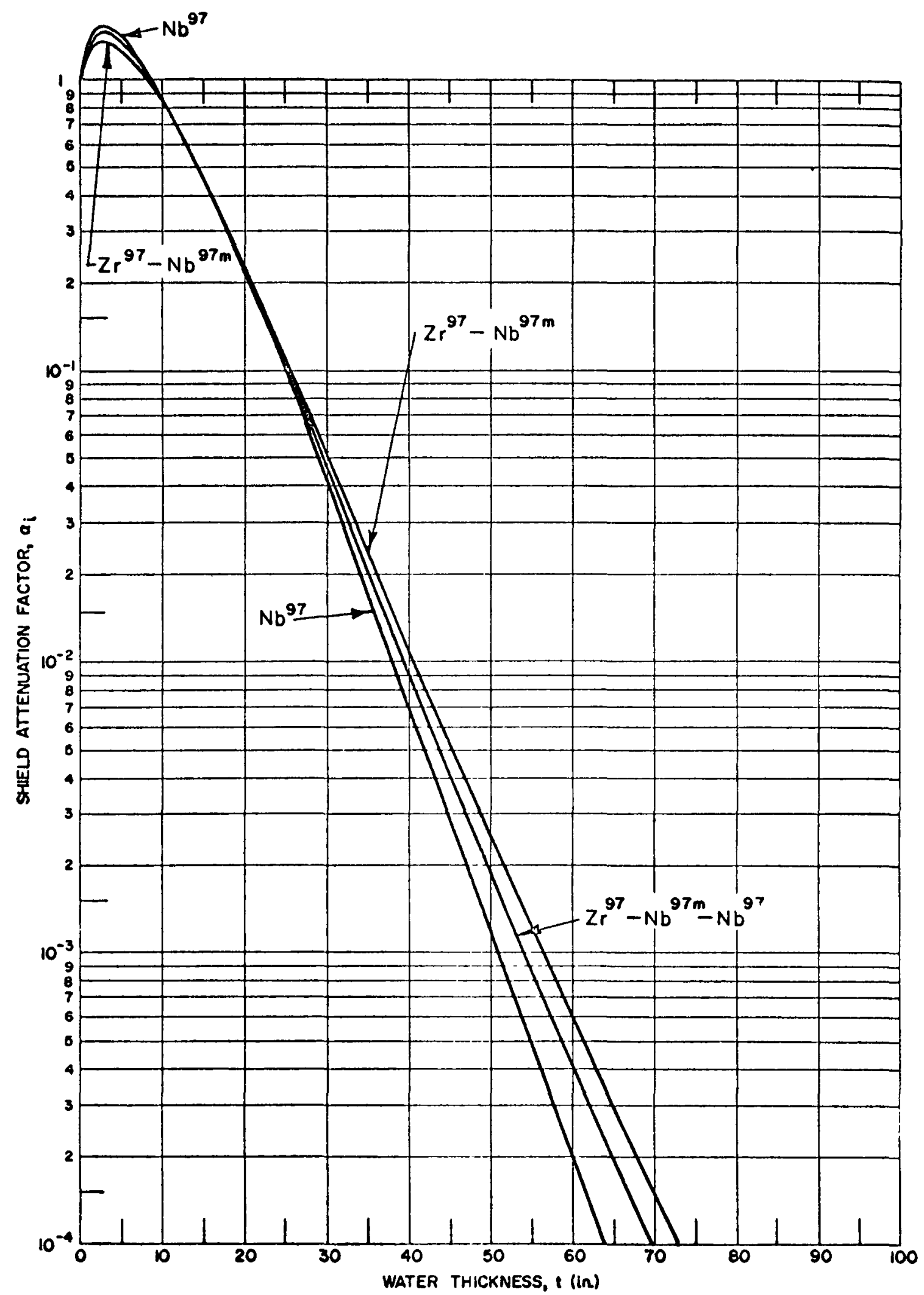

FIGURE $8 B$ 


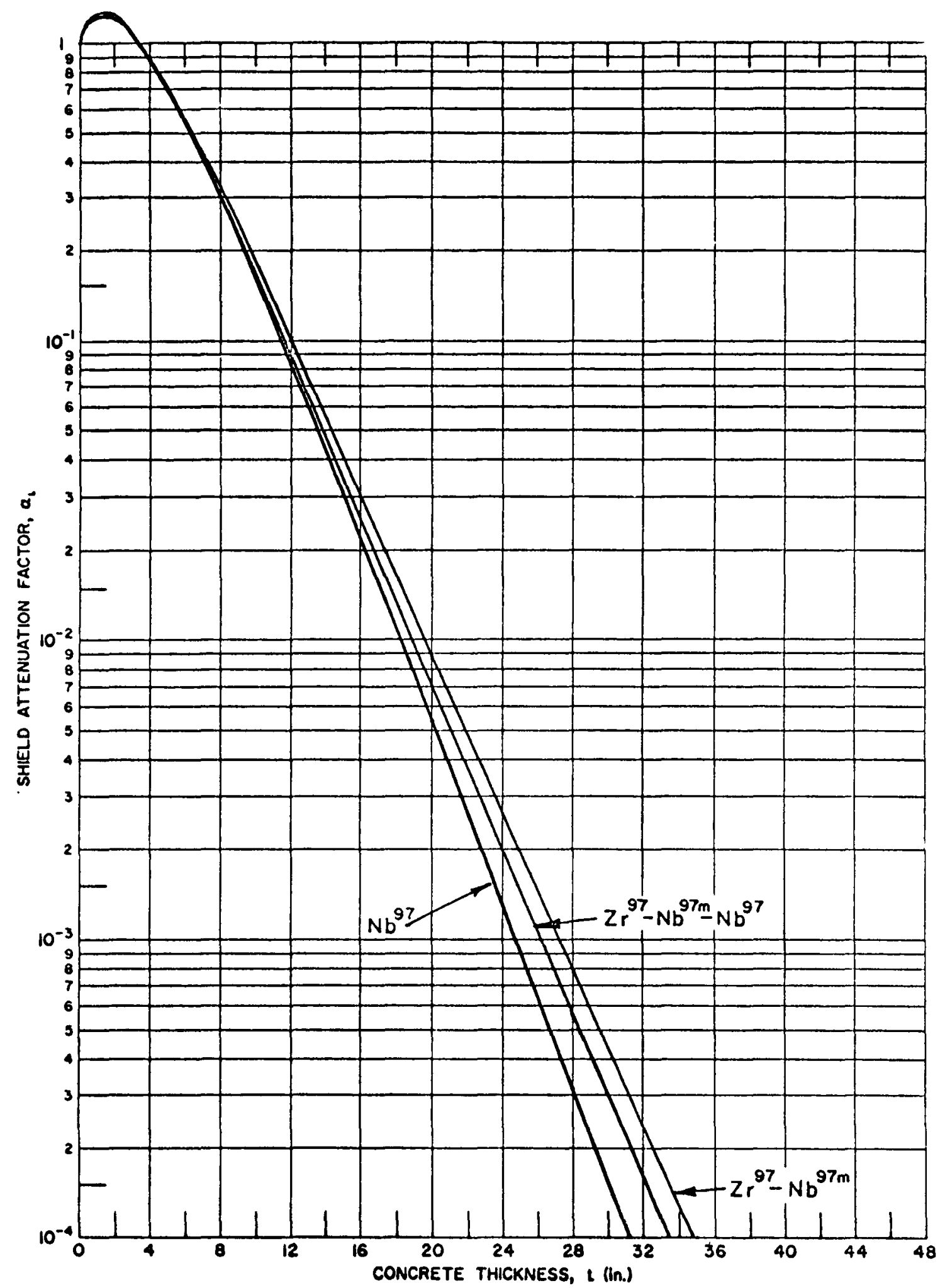

FIGURE $8 C$

- 61 - 


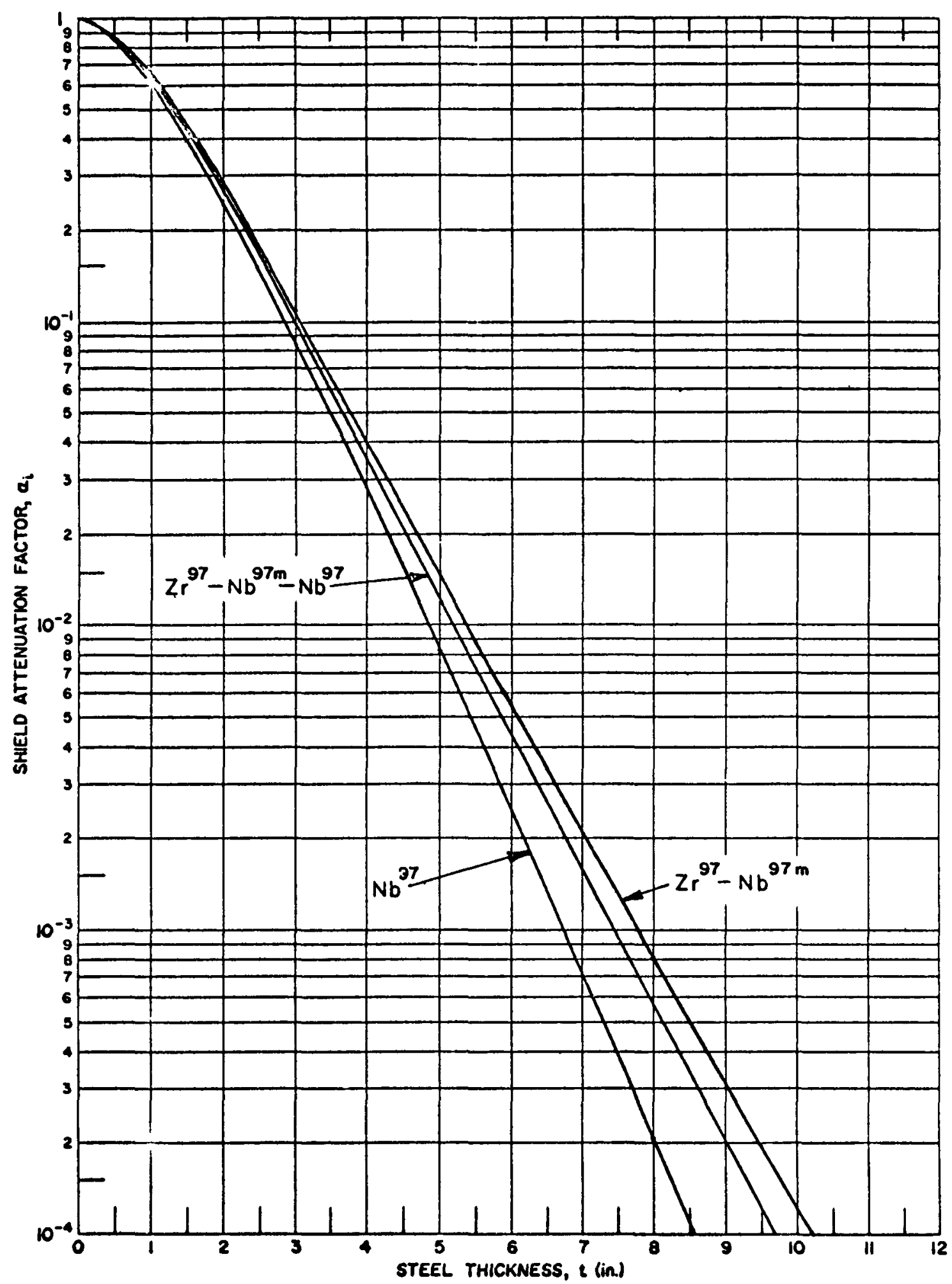

FIGURE 80 


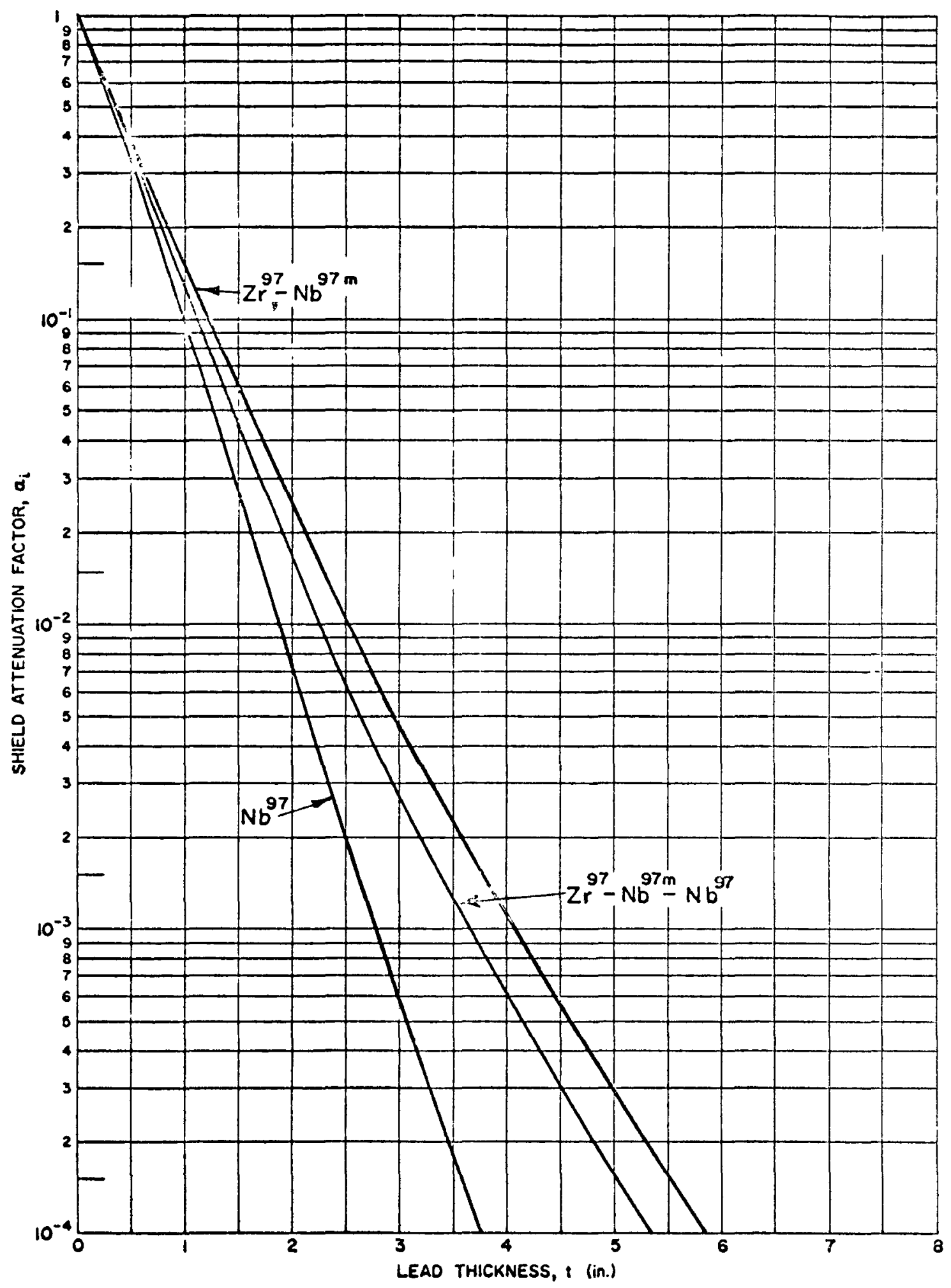

FIGURE $8 E$ 


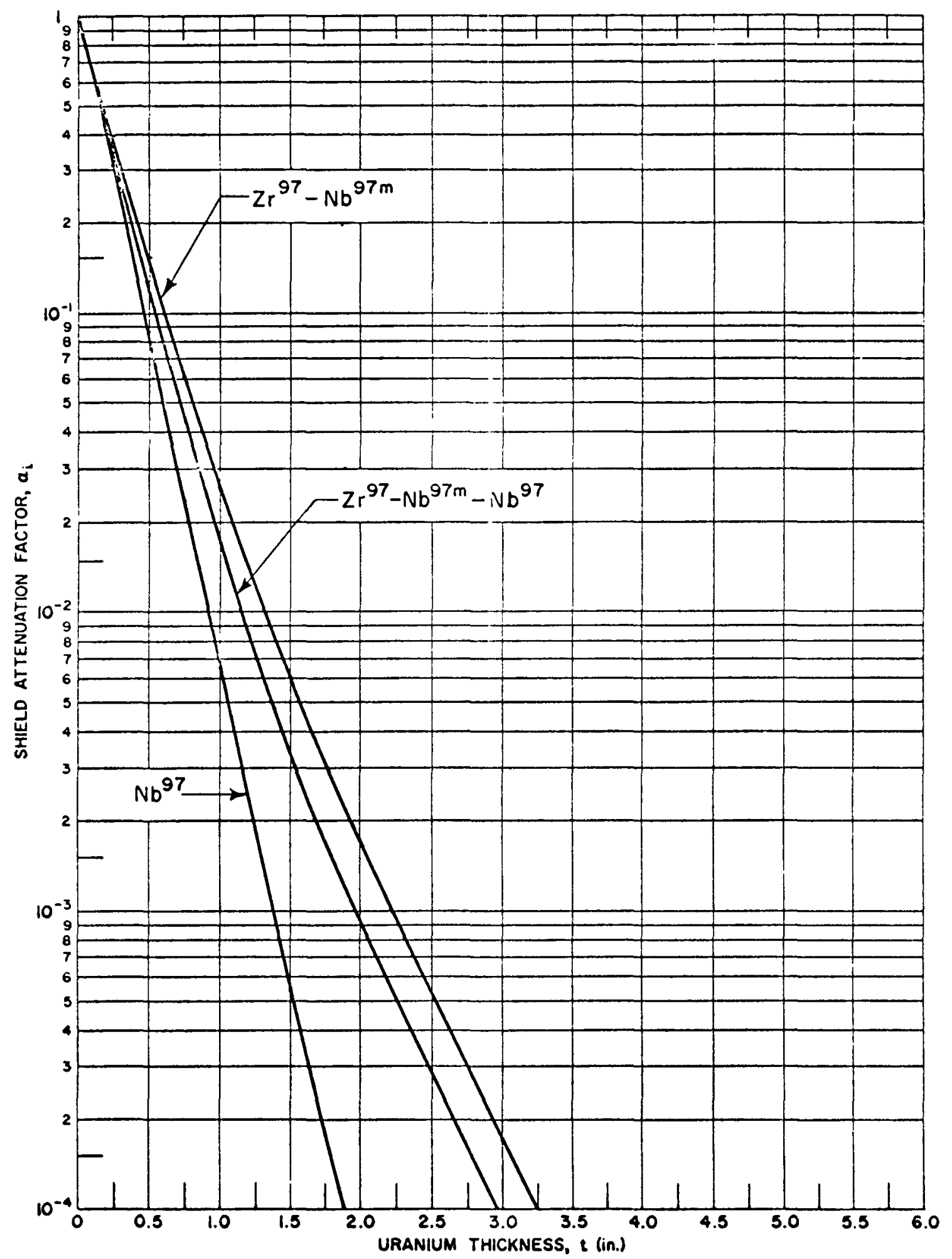

FIGURE BF 


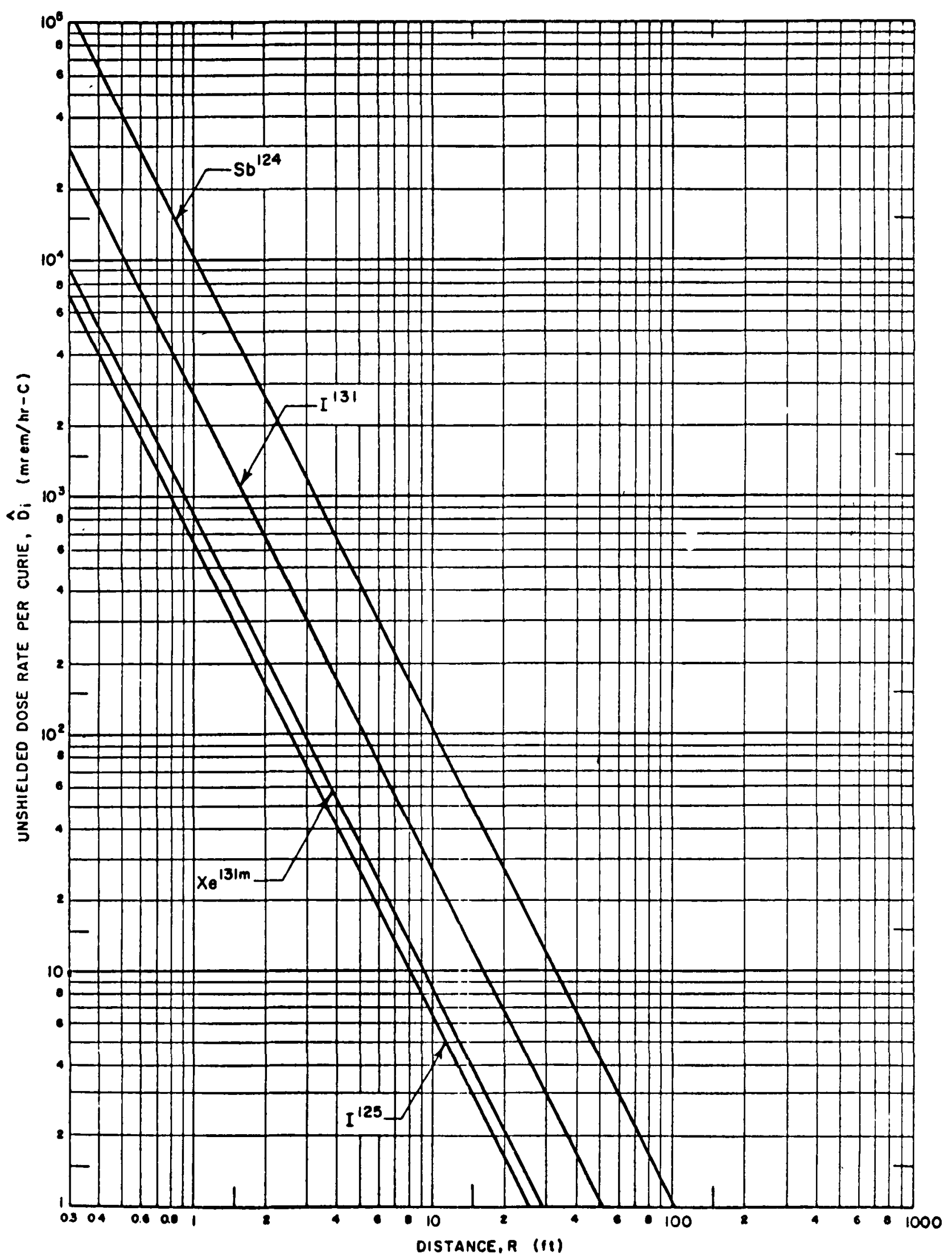

FIGURE 9A 


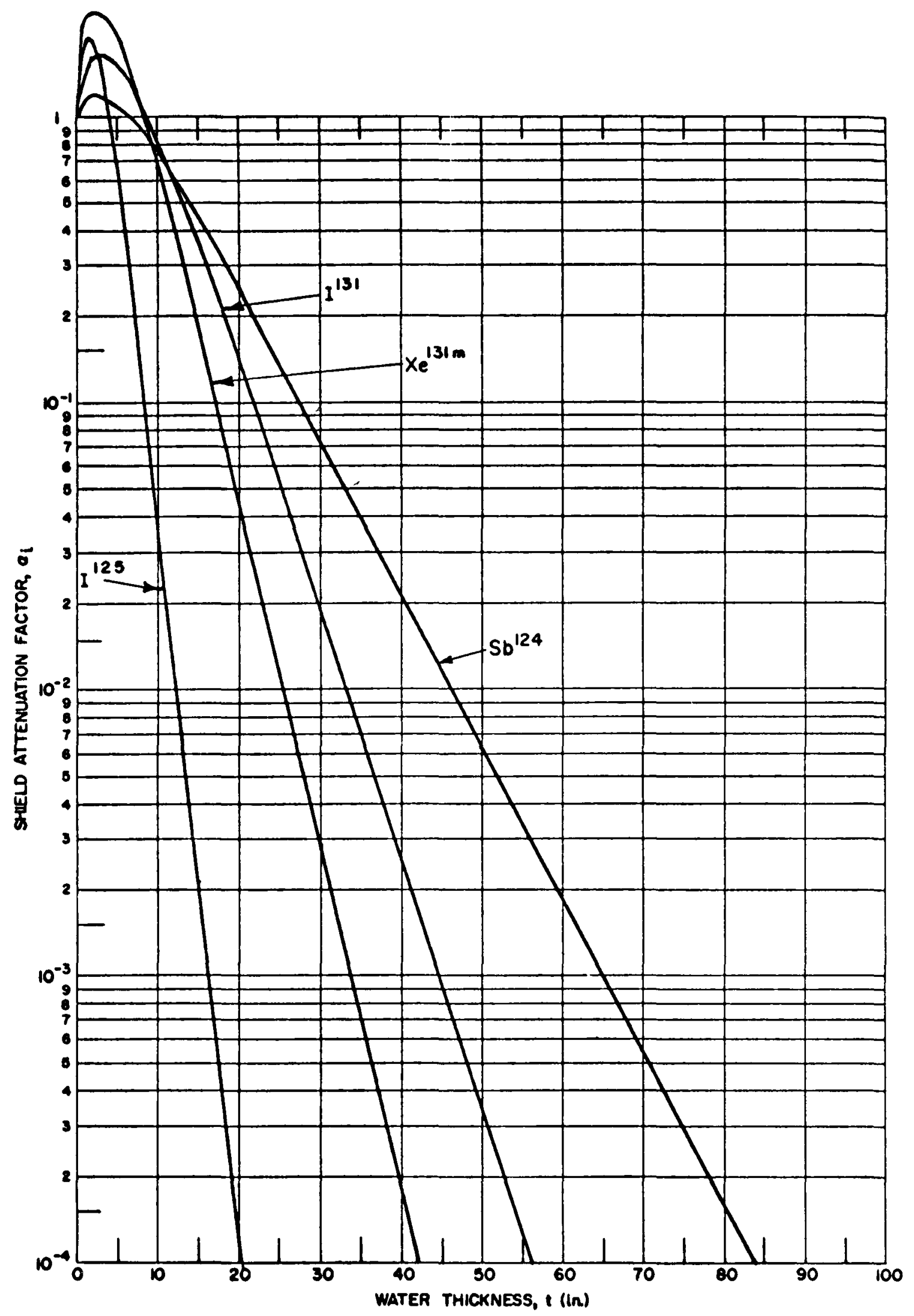

FIGURE $9 B$ 


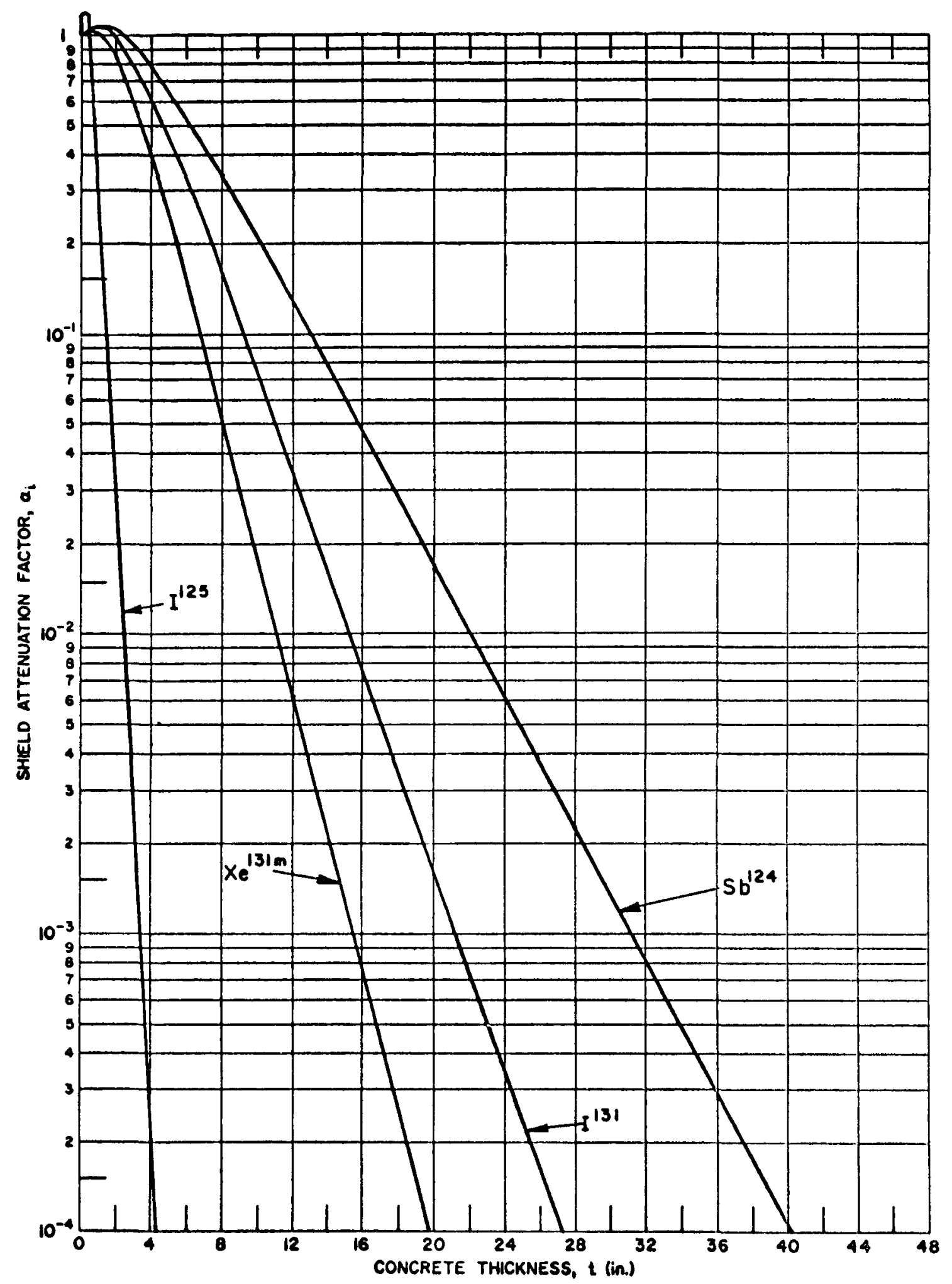

FIGURE $9 C$

- 67 - 


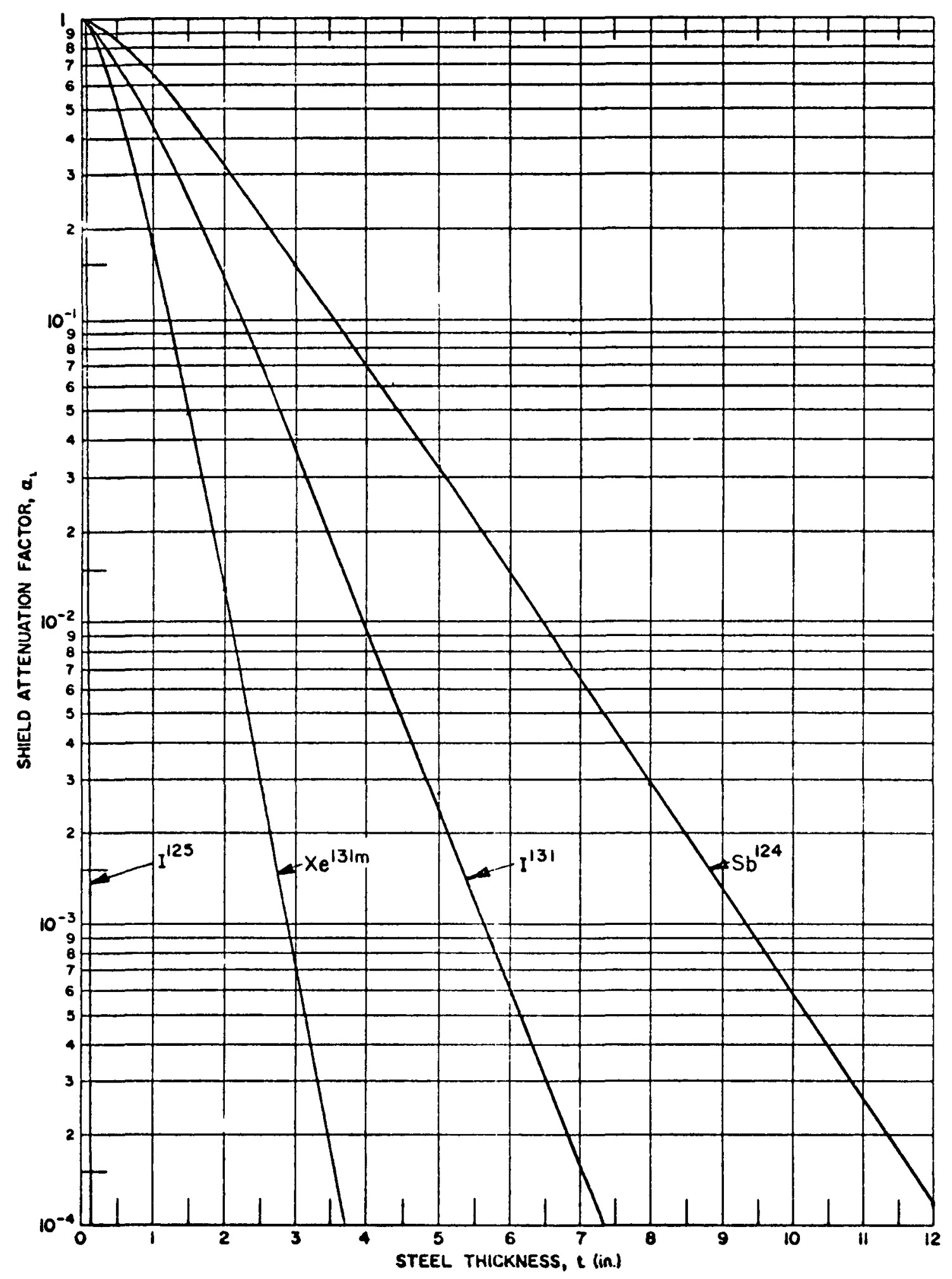

FIGURE 90 


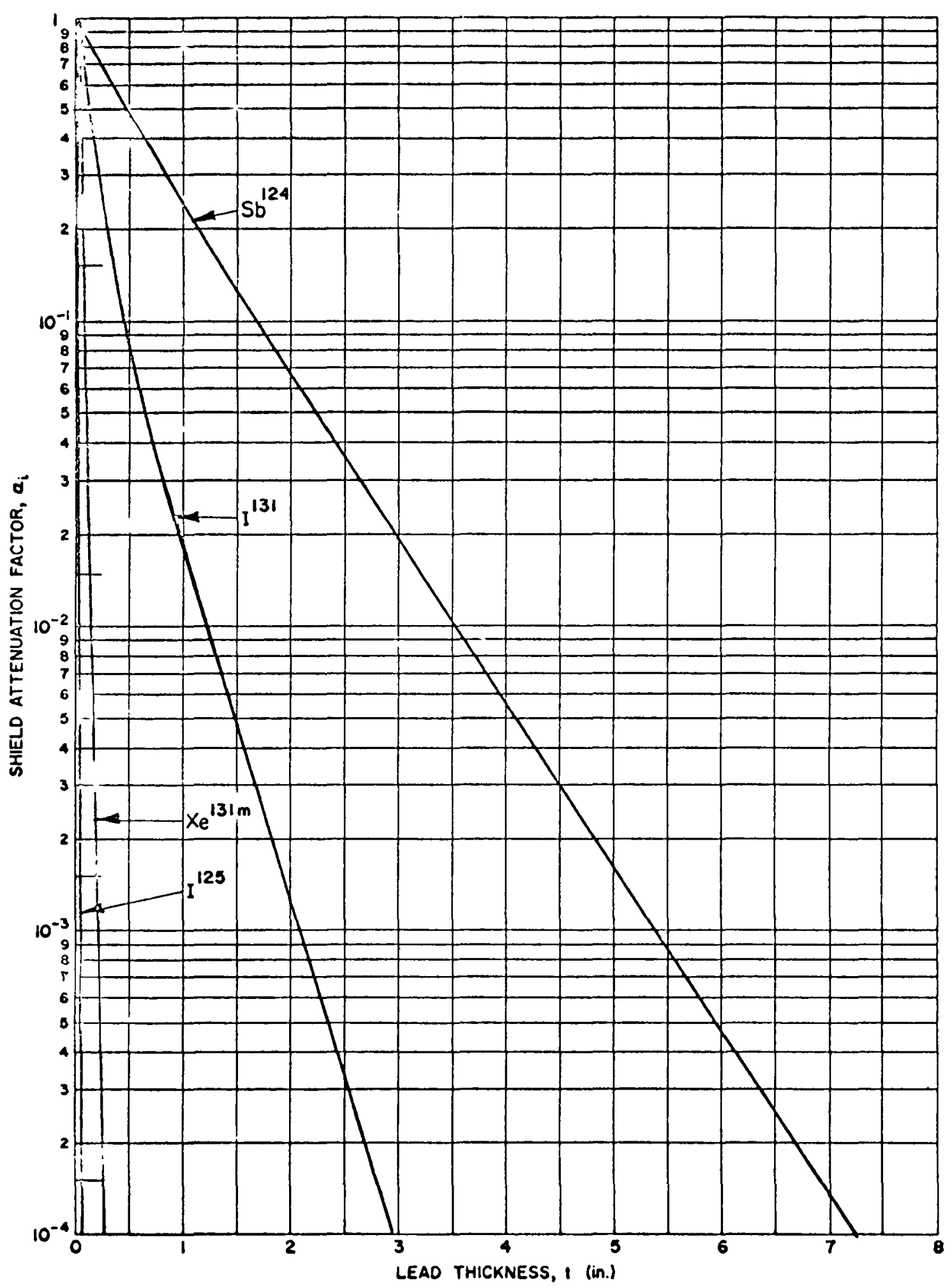

FIGURE $9 E$ 


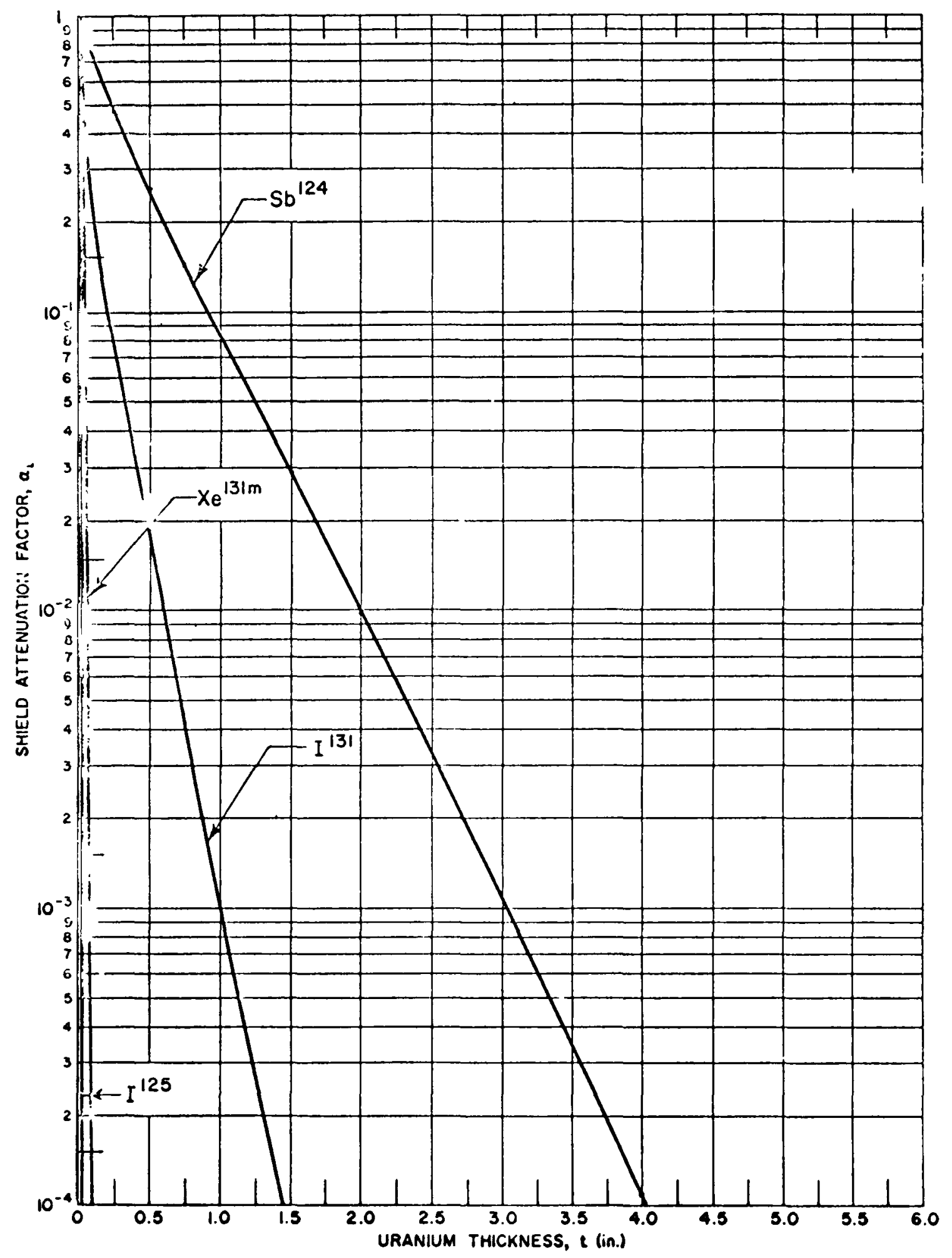

FIGURE OF 


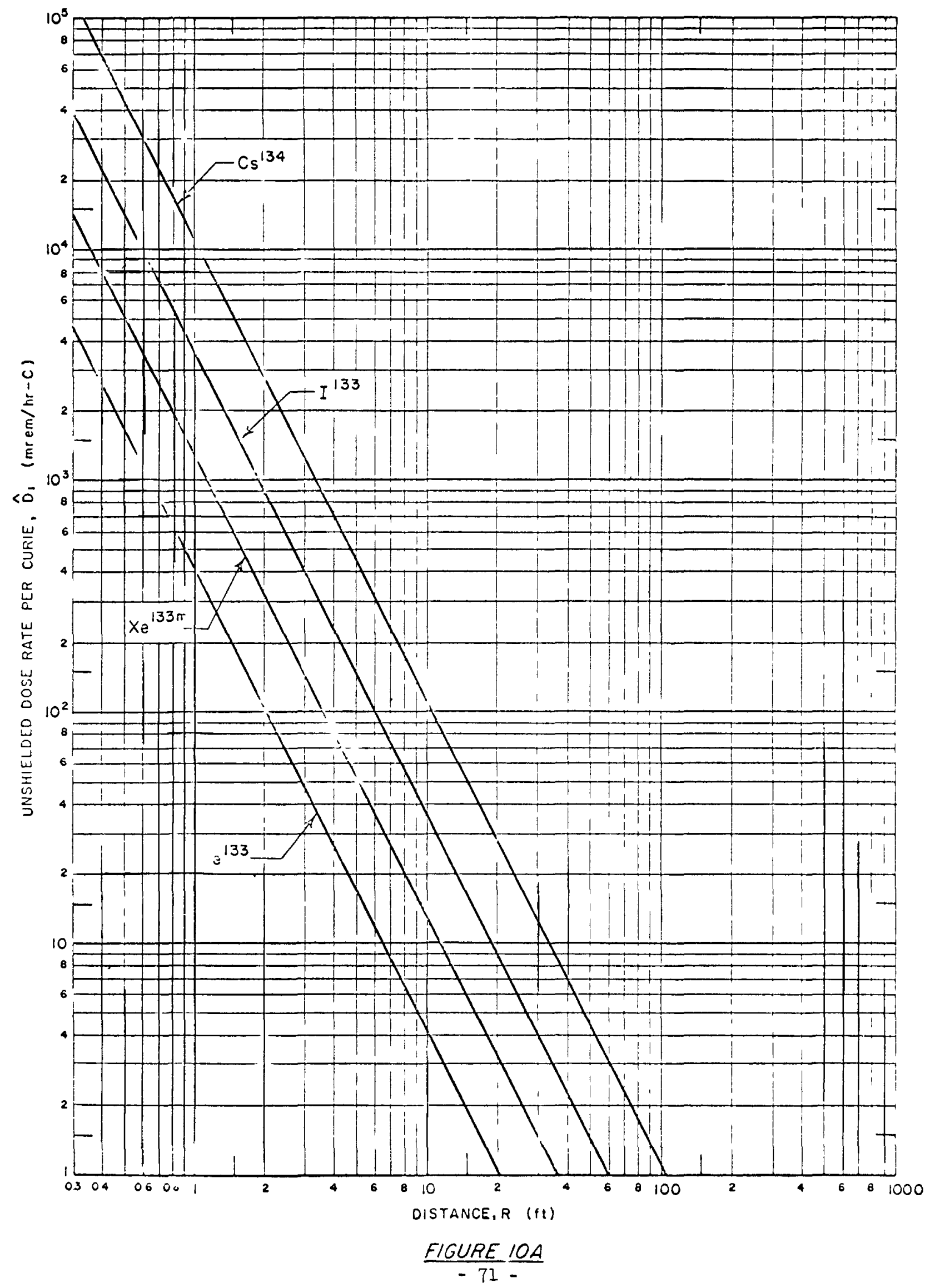




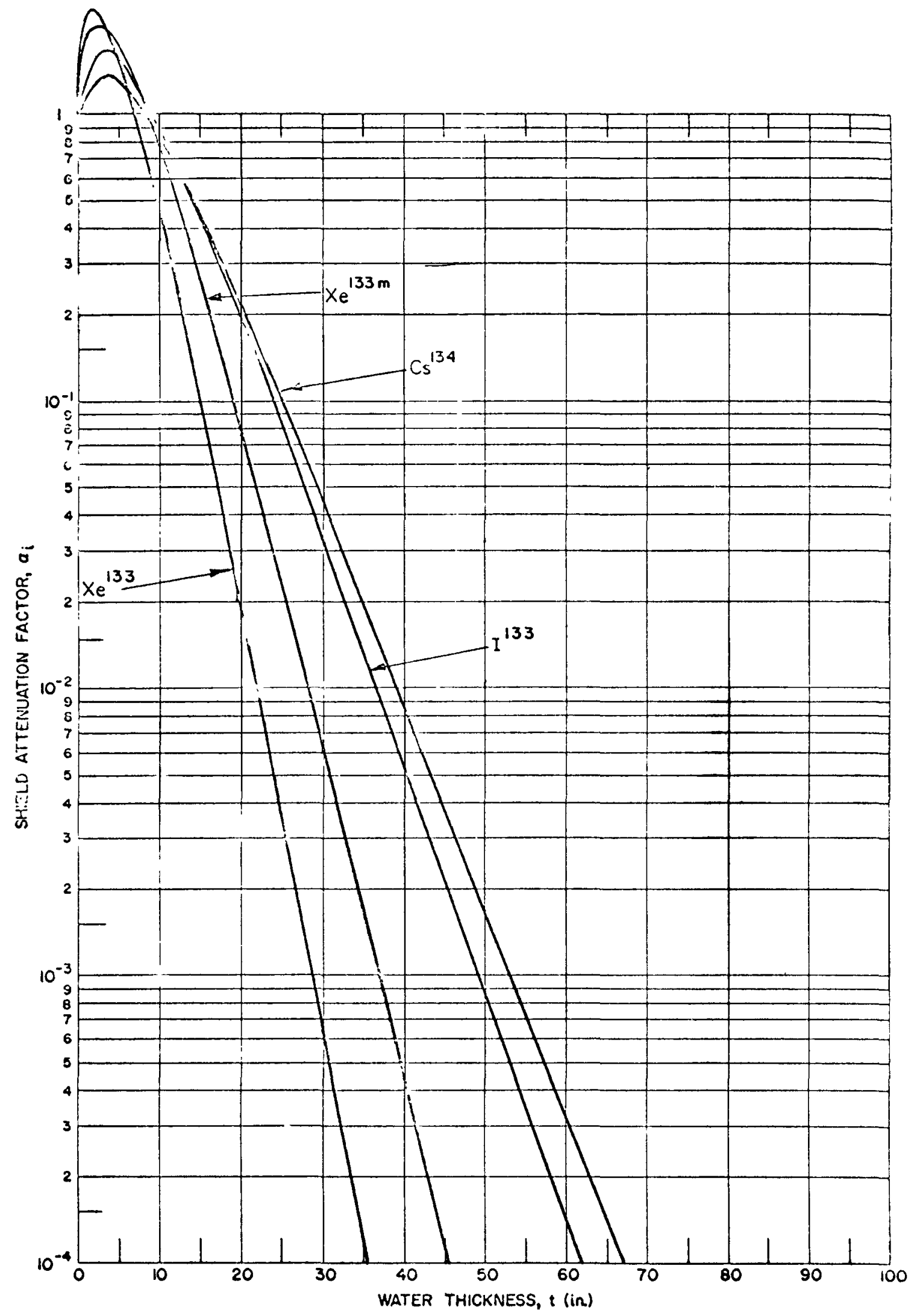

FIGURE $10 B$ 


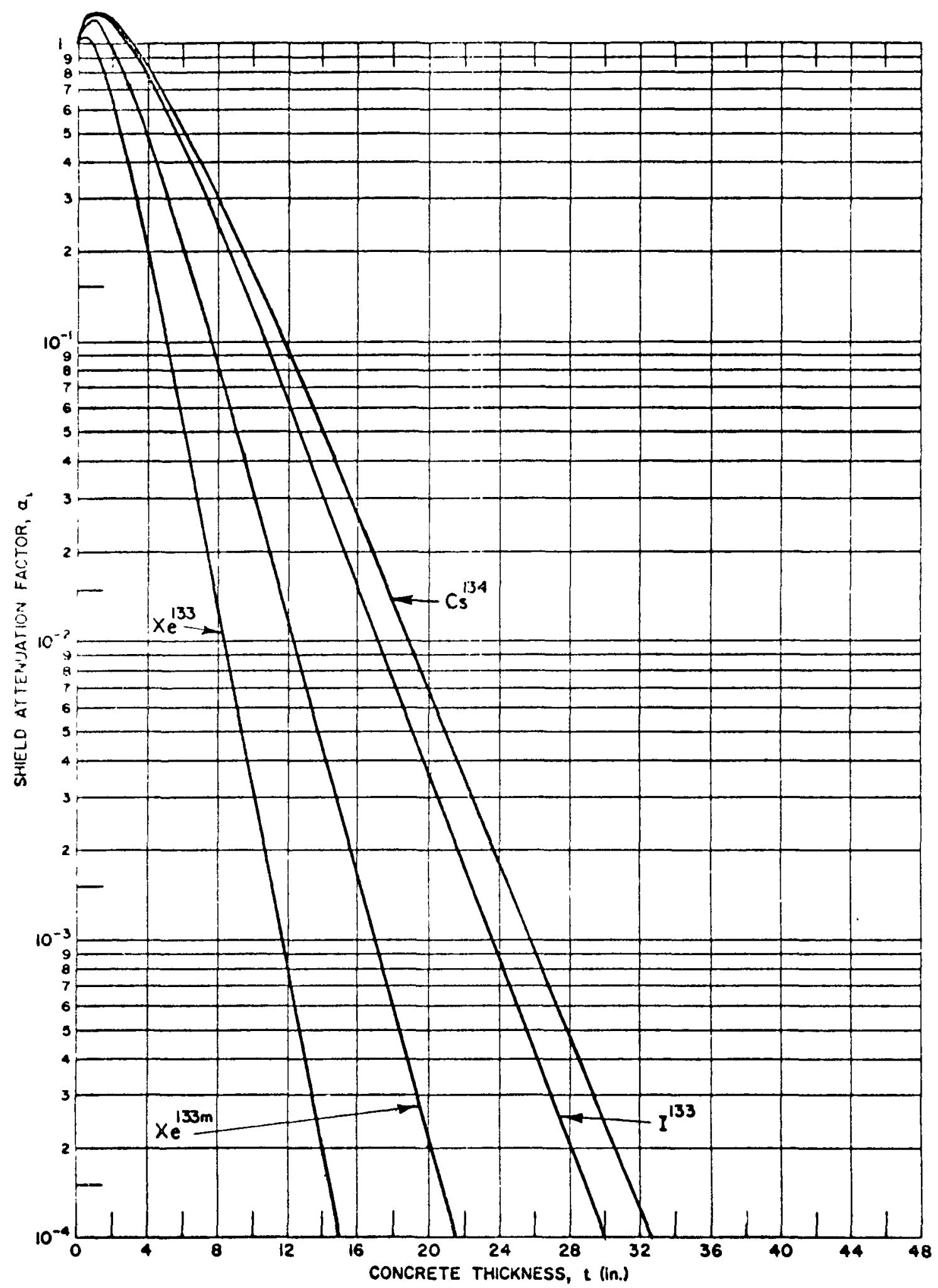

FIGURE $10 \mathrm{C}$ 


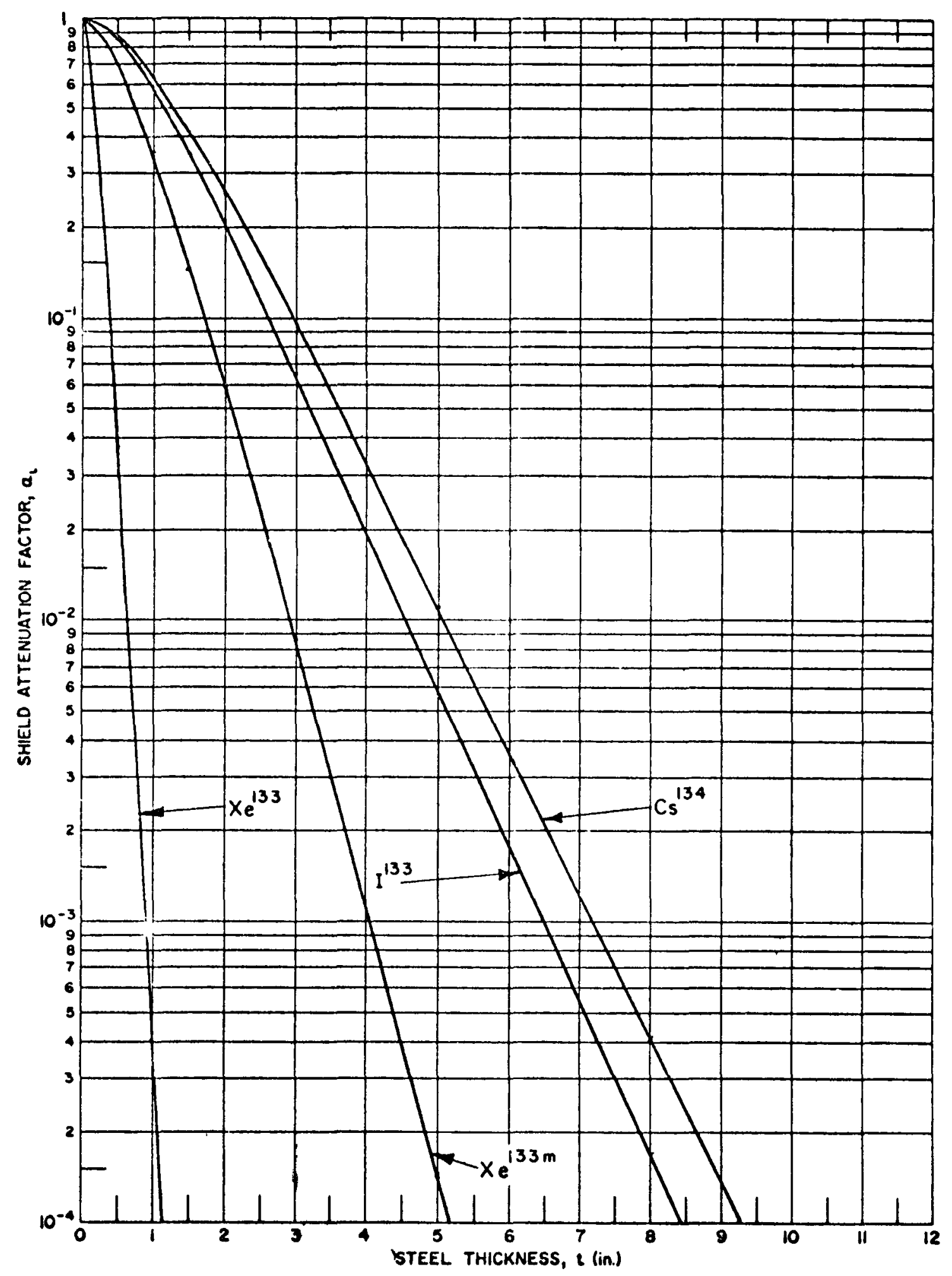

FIGURE 100 


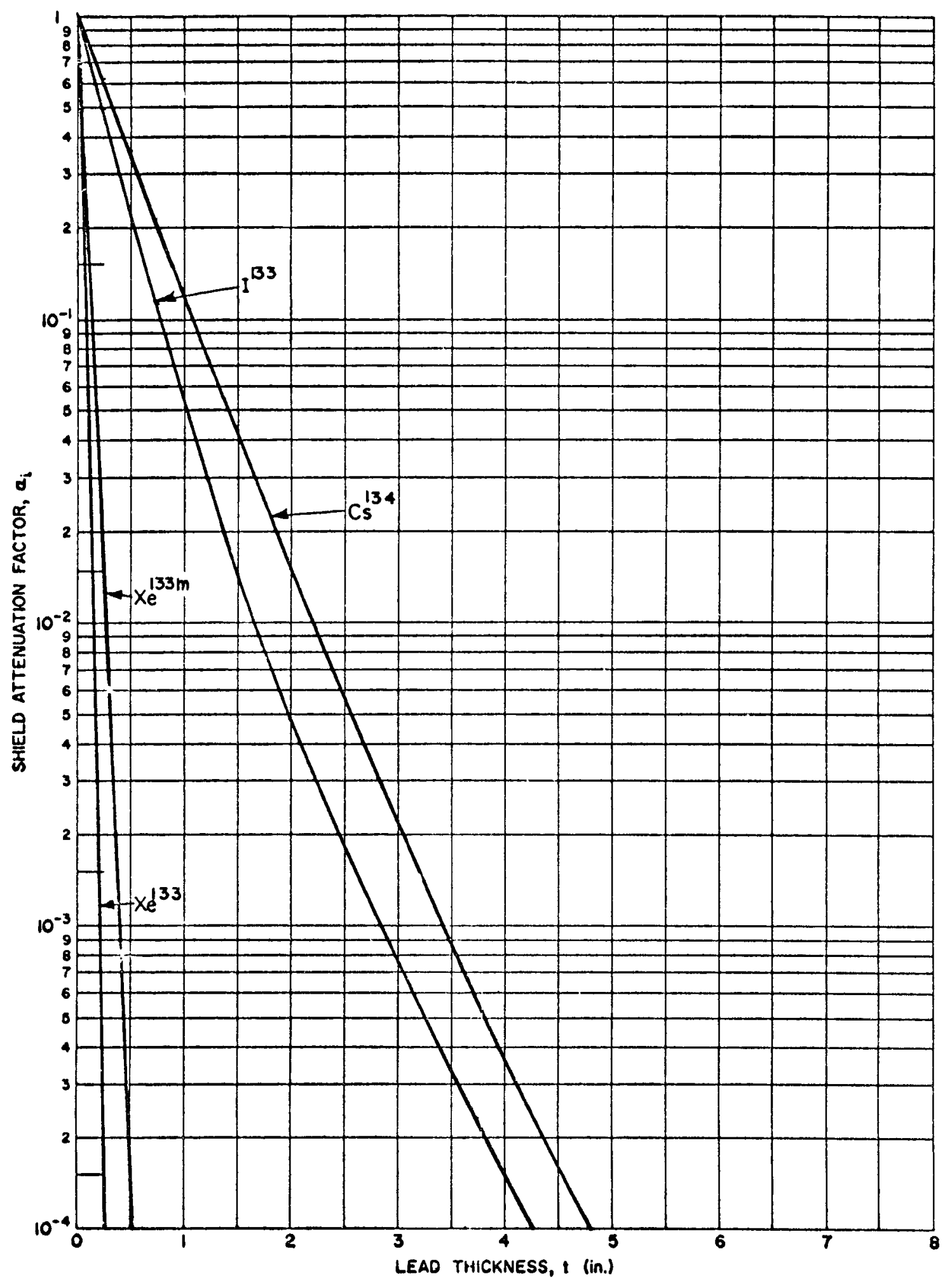

FIGURE IOE 


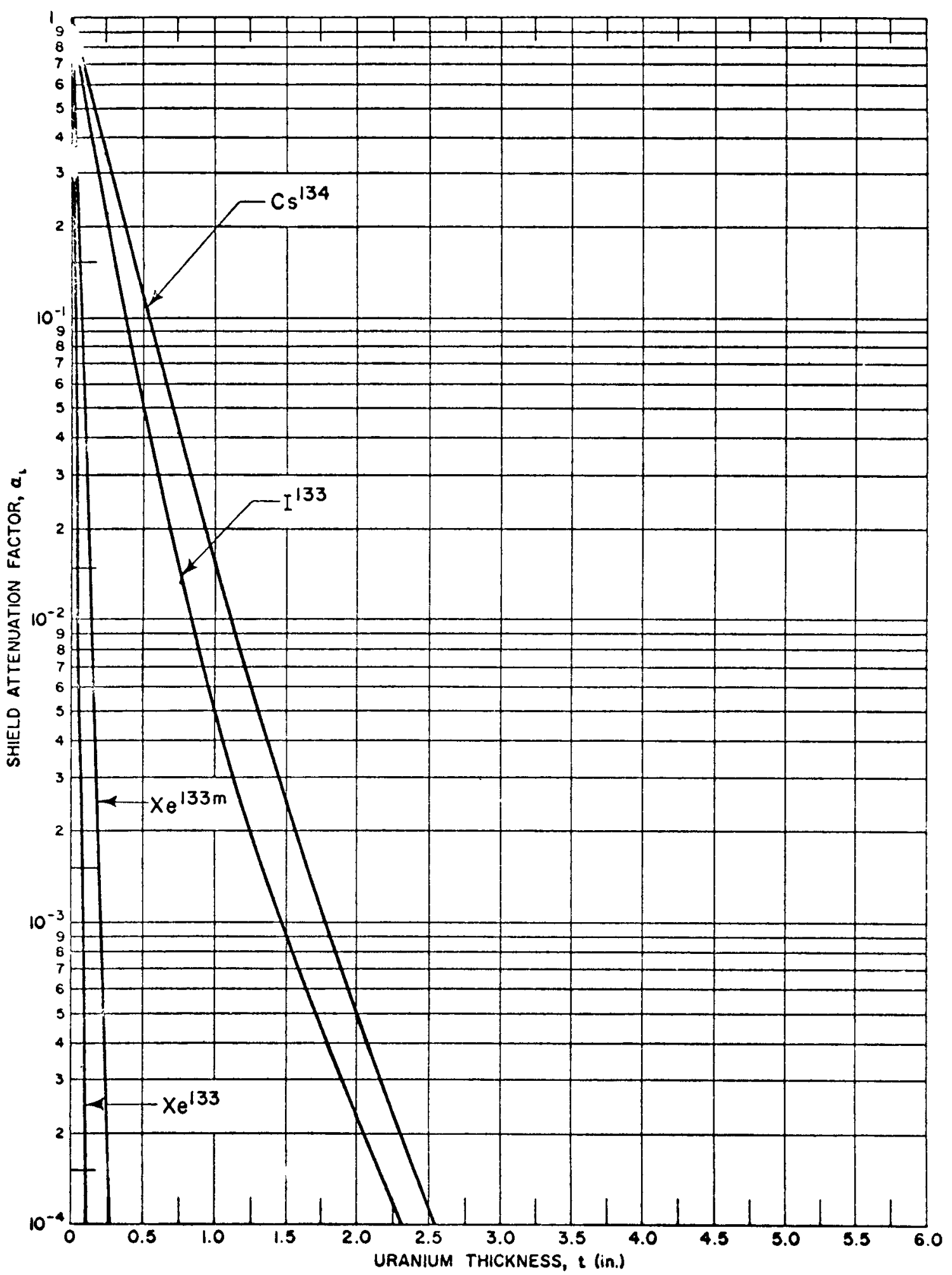

FIGURE IOF

- 76 - 


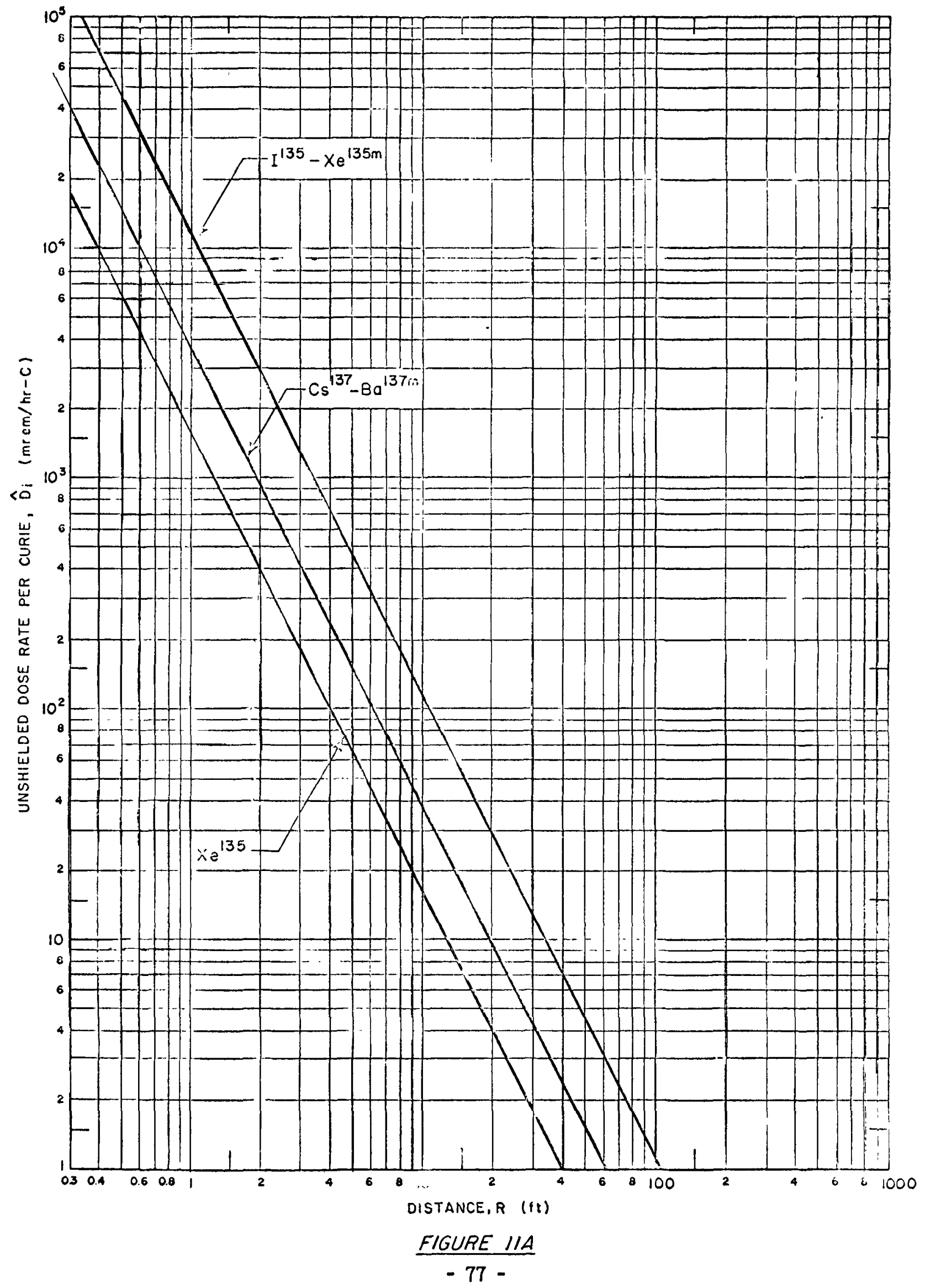




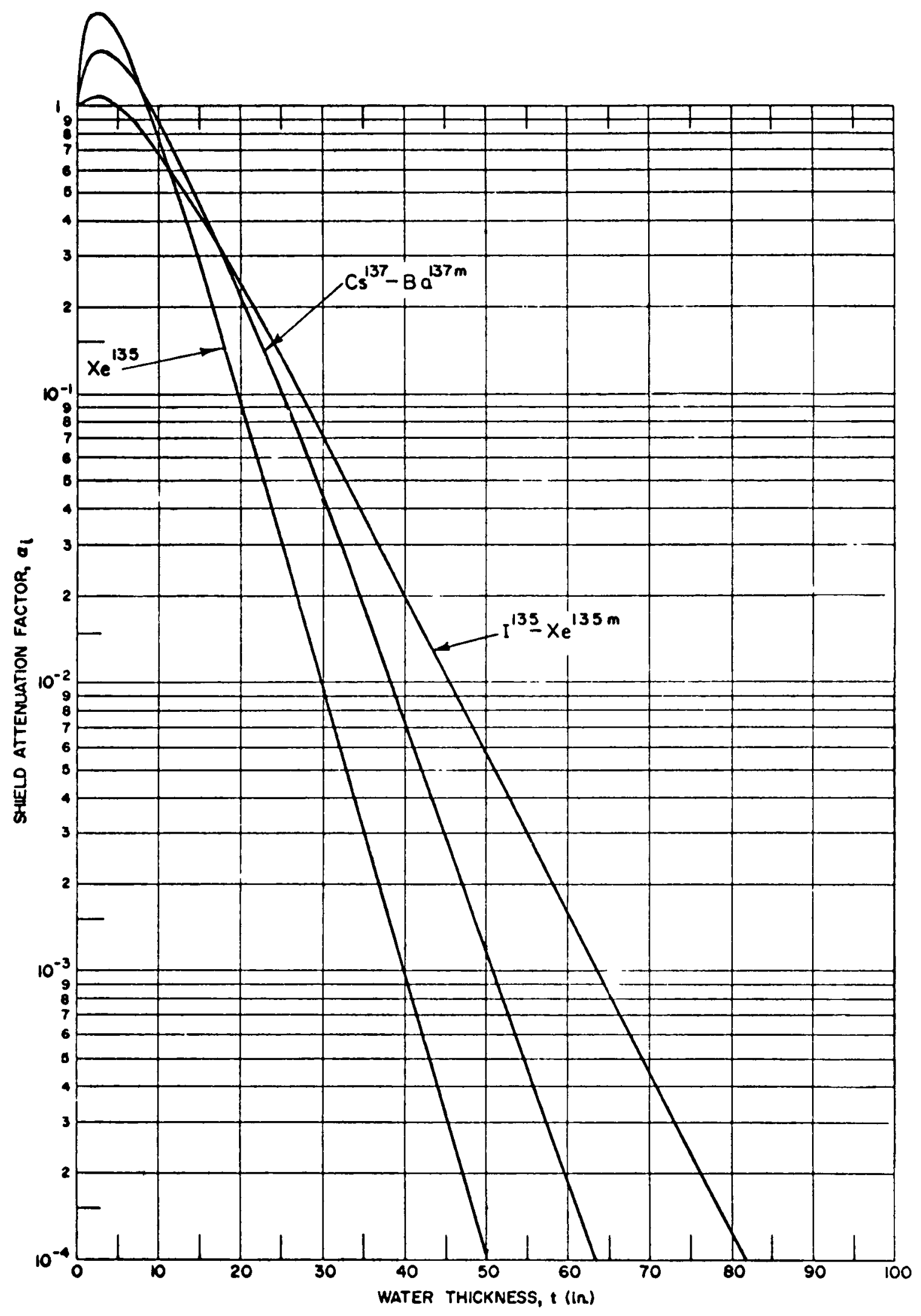

FIGURE IIB 


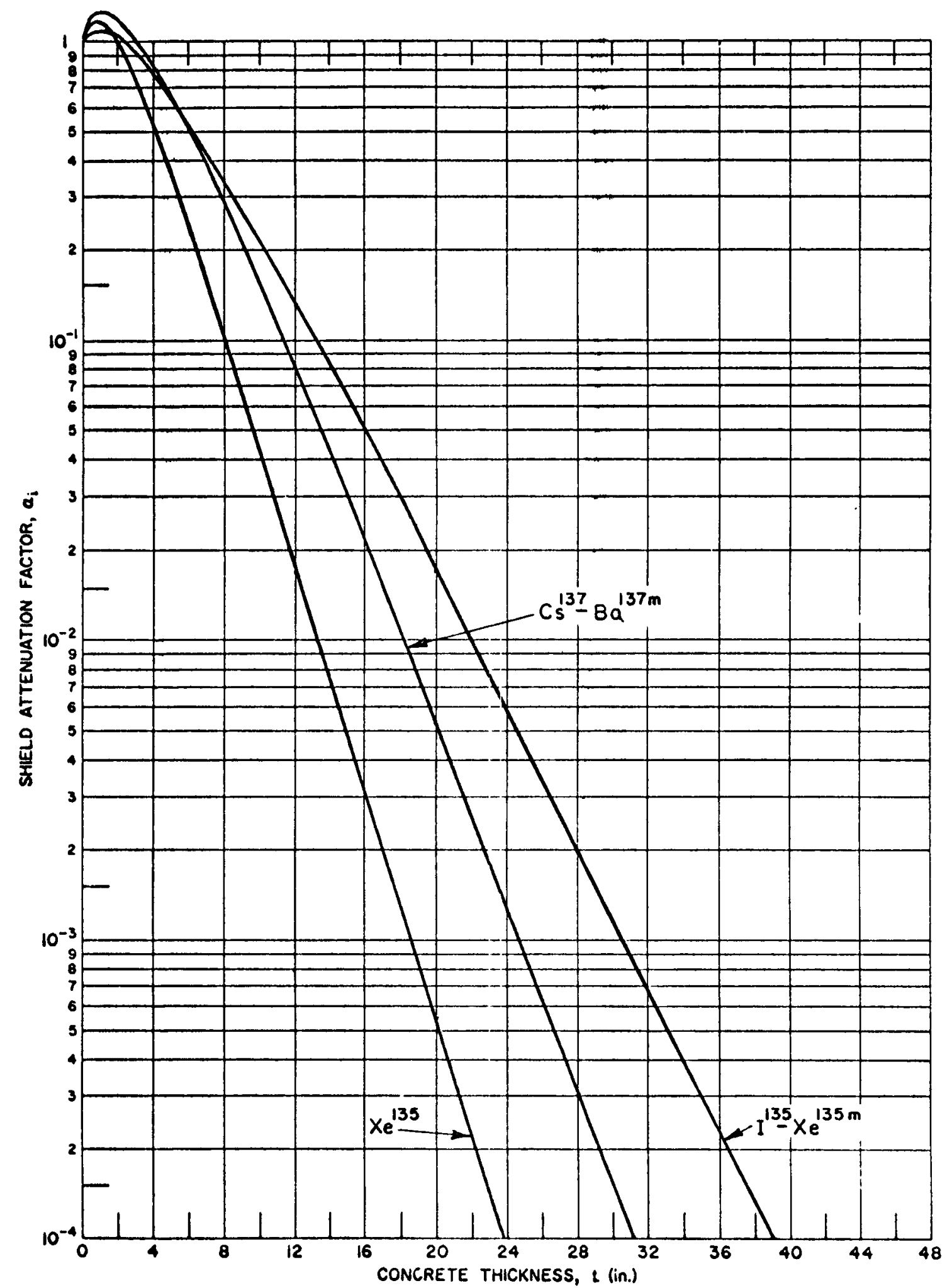

FIGURE \|C 


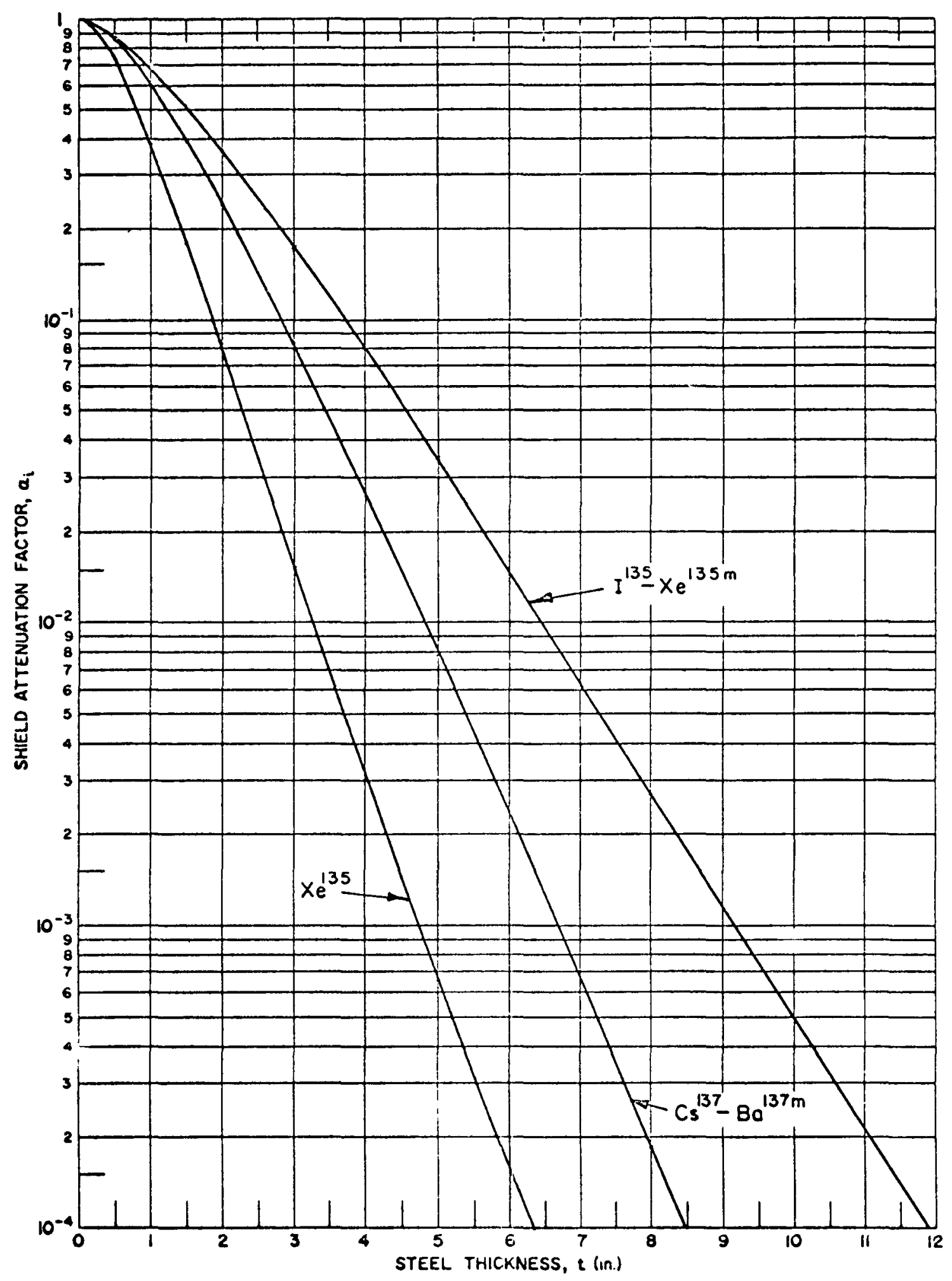

FIGURE IID 


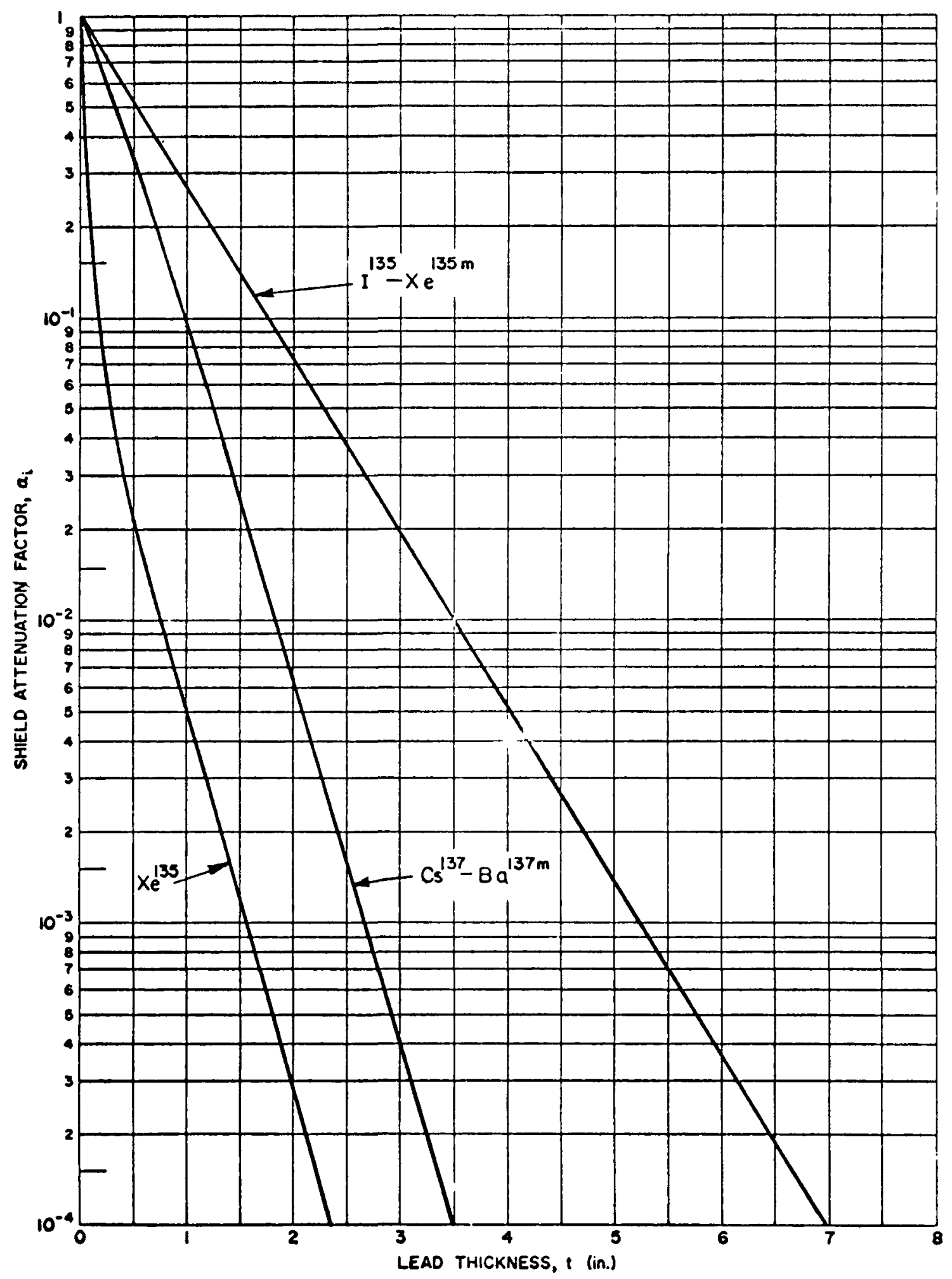

FIGURE IIE

- 81 - 


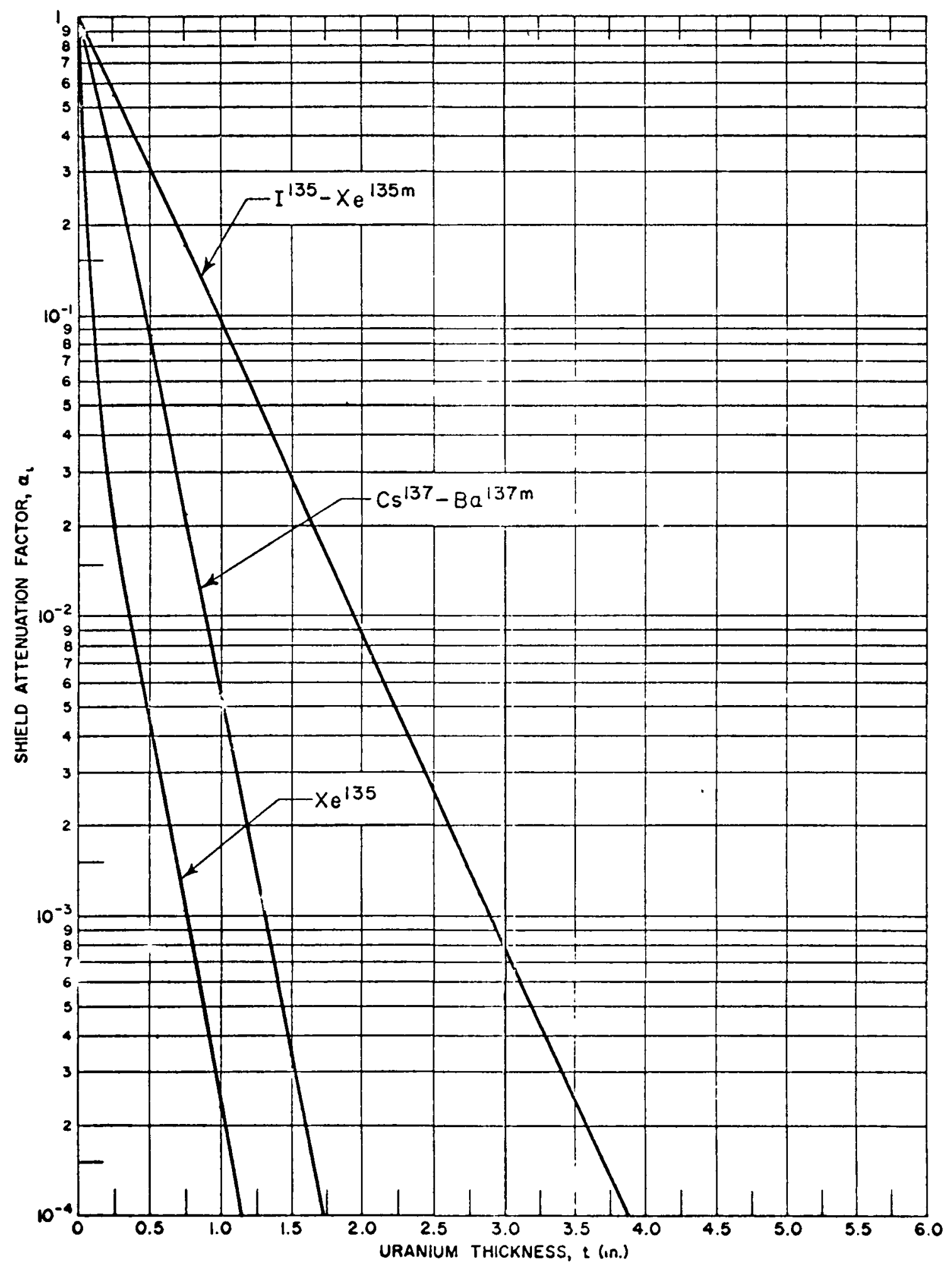

FIGURE IIF 


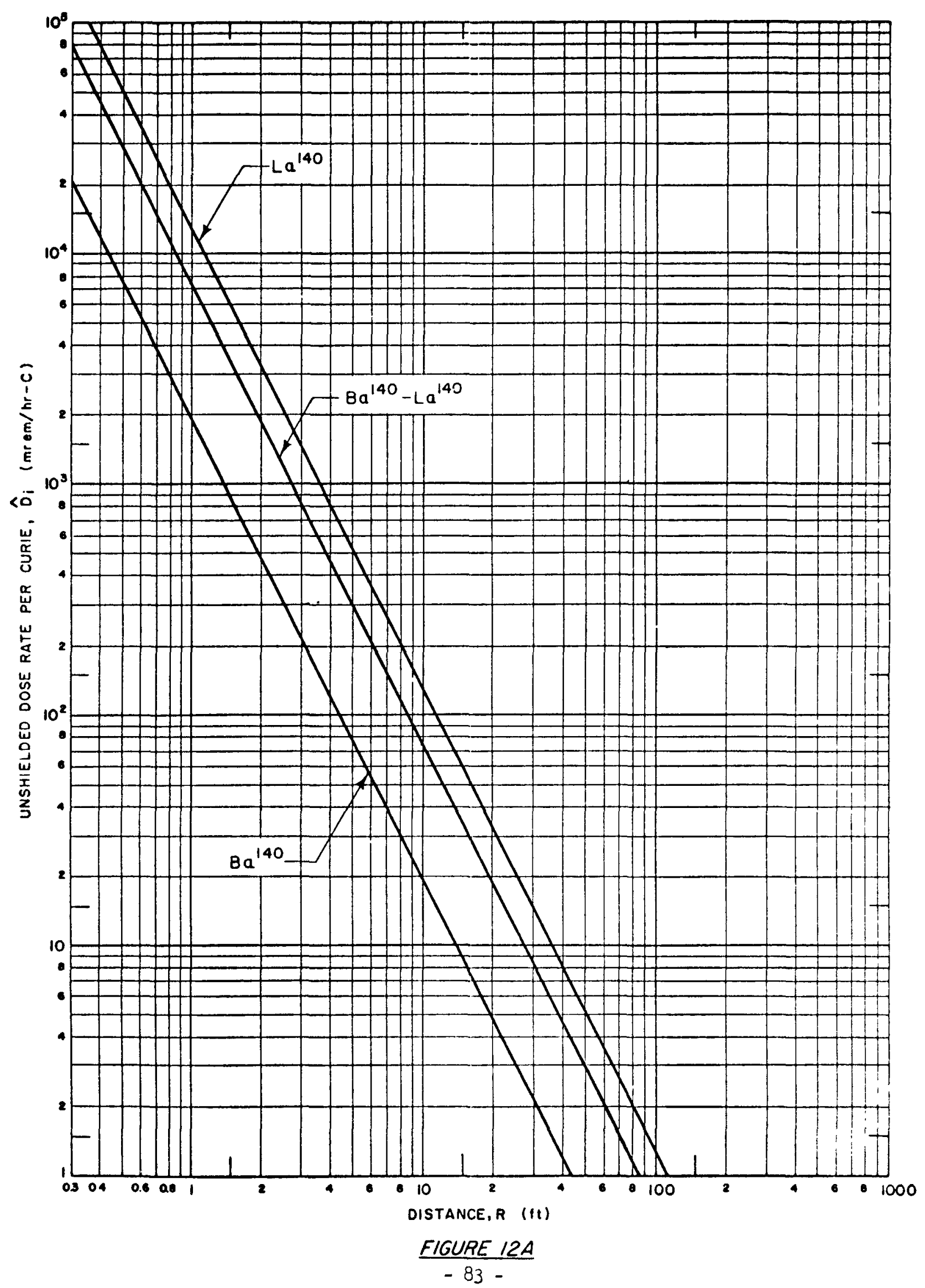




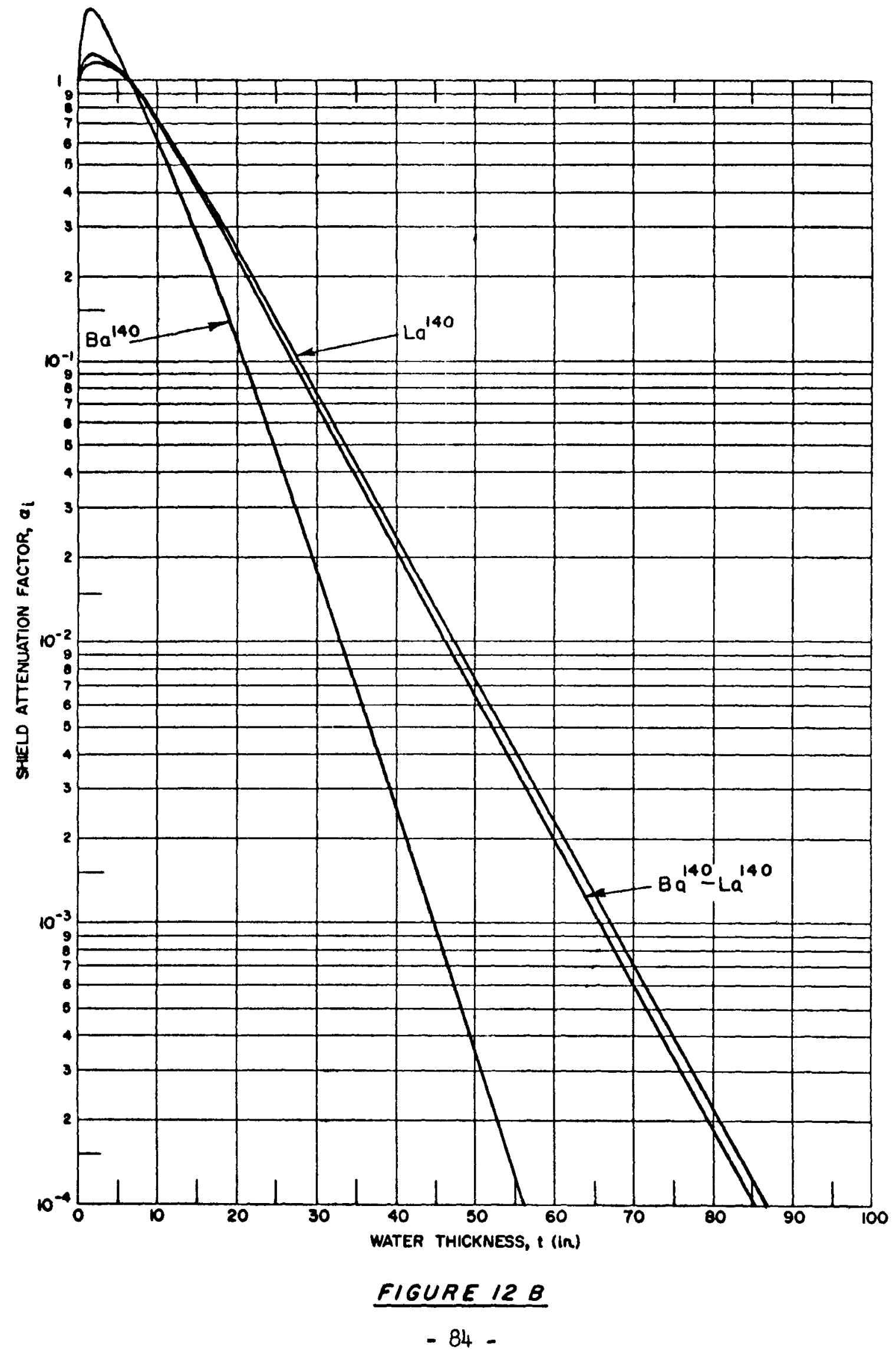




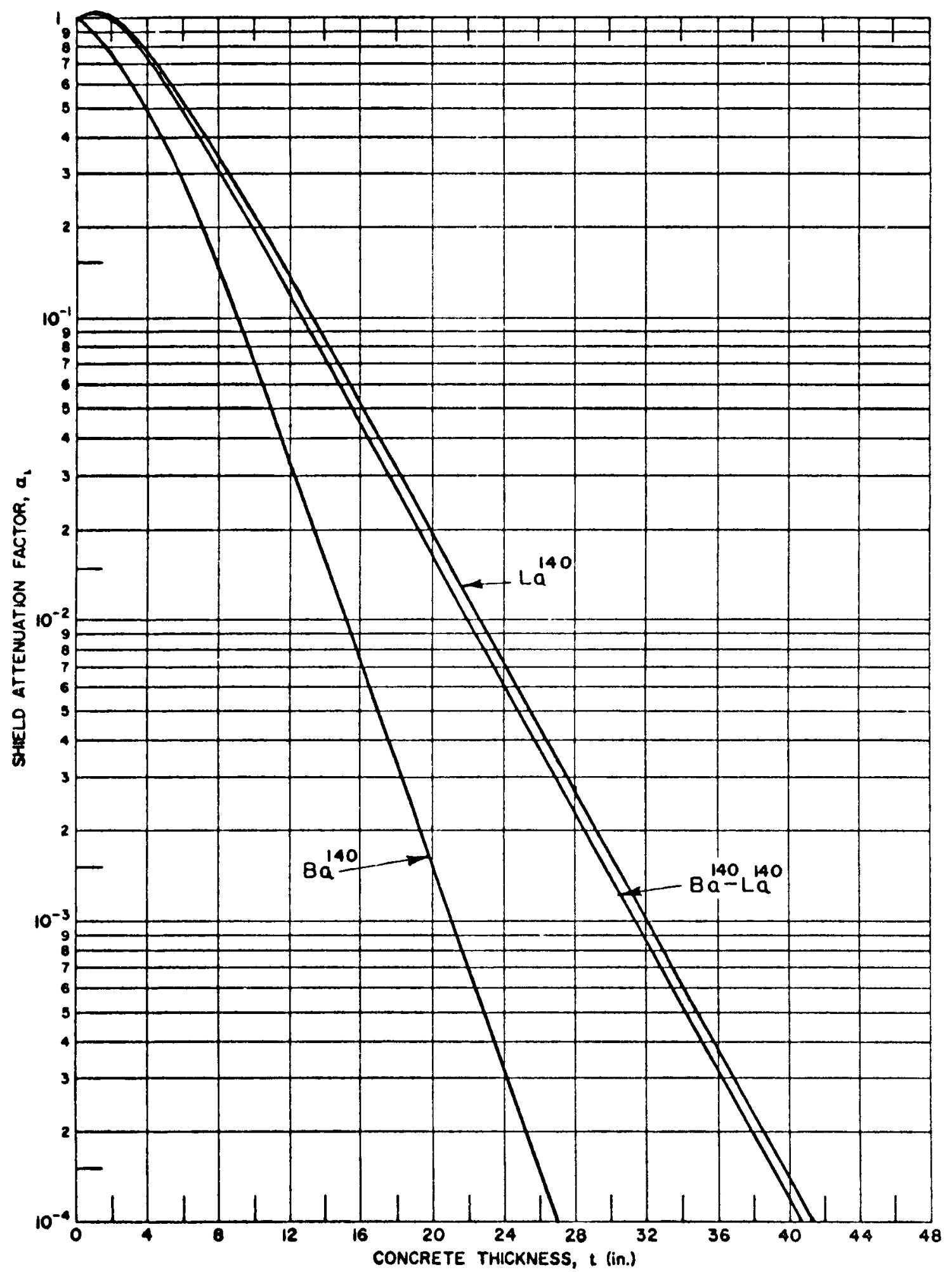

FIGURE $12 C$ 


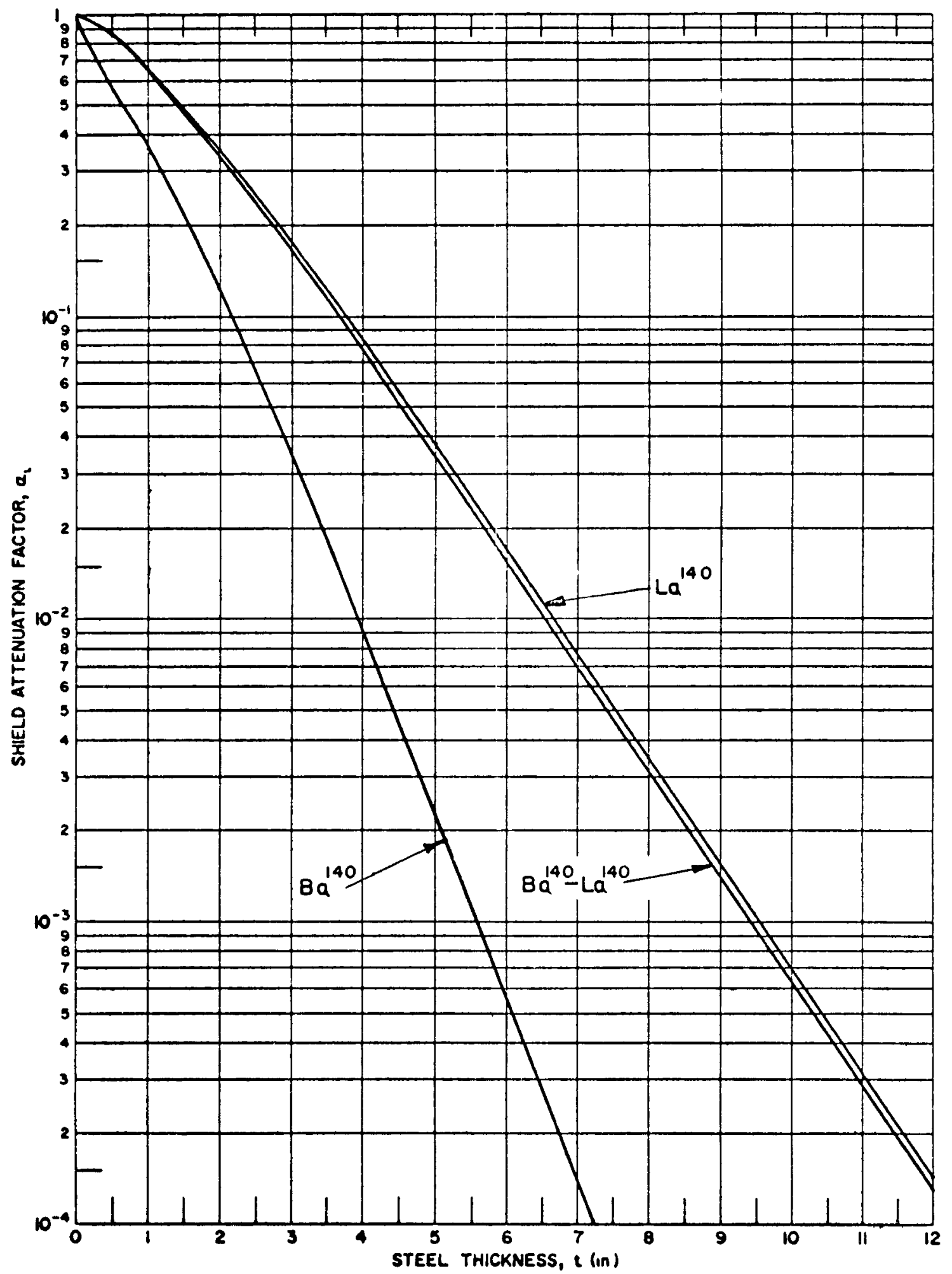

FIGURE 120 . 


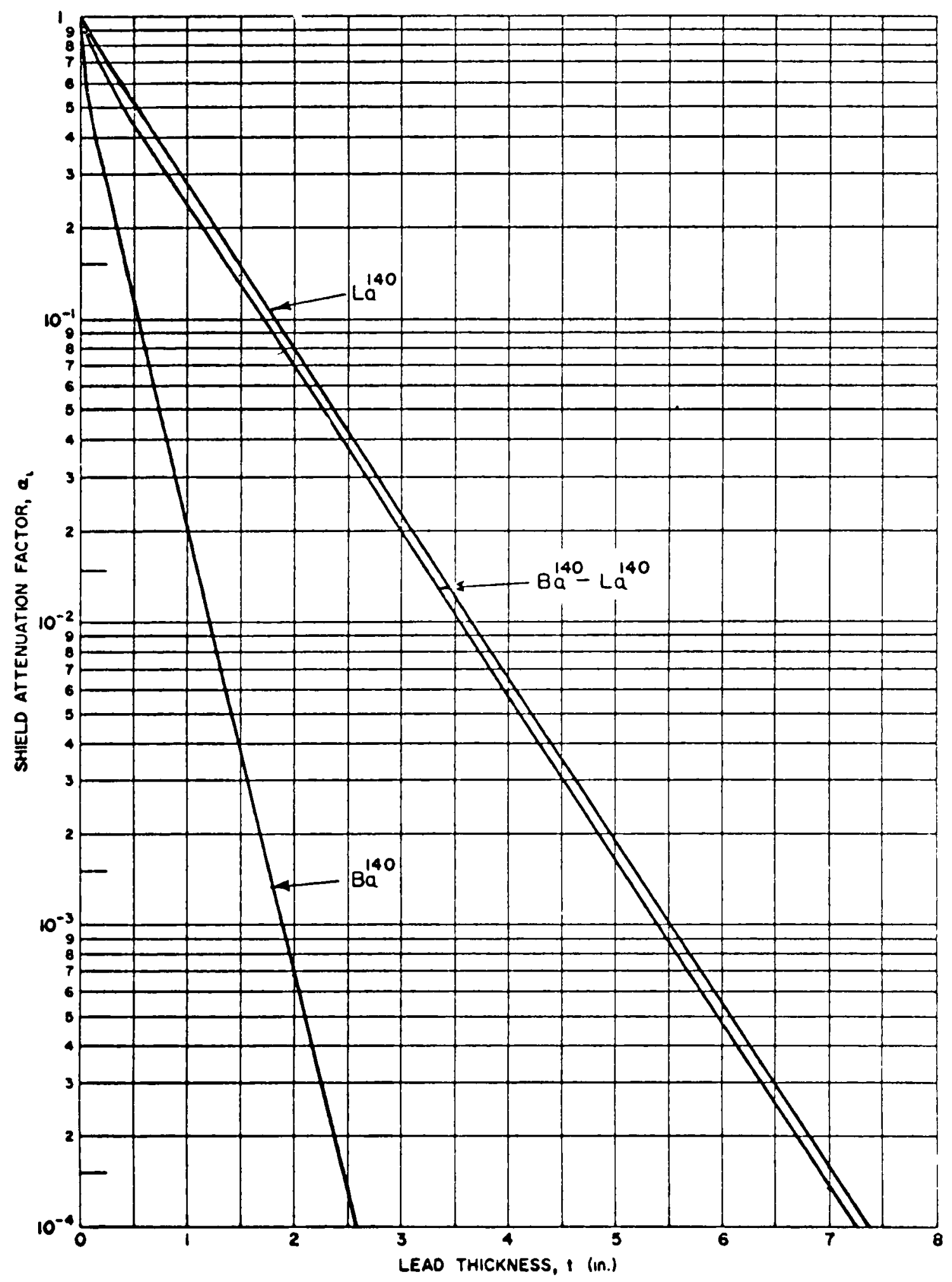

FIGURE $12 E$ 


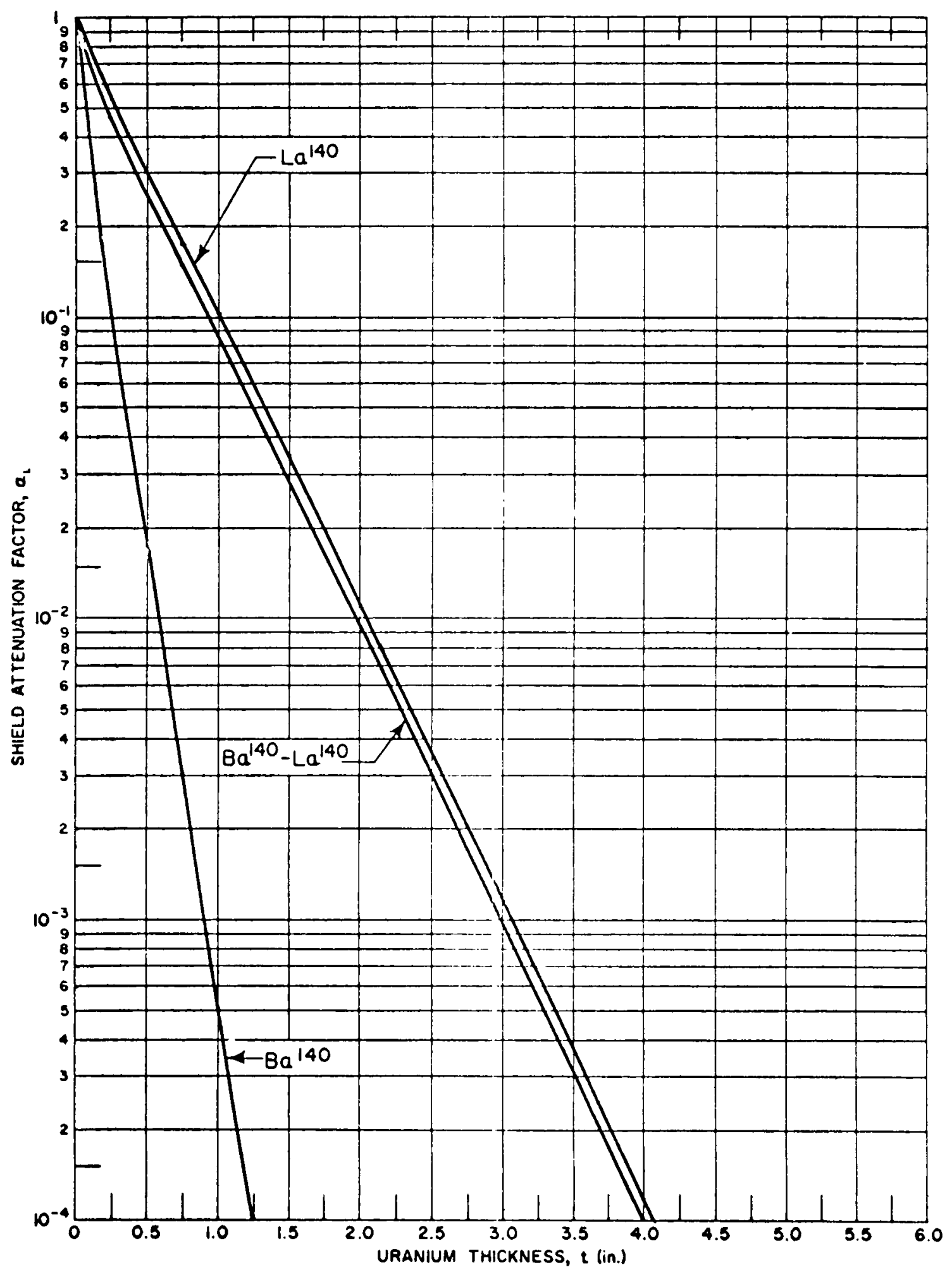

FIGURE I2F 


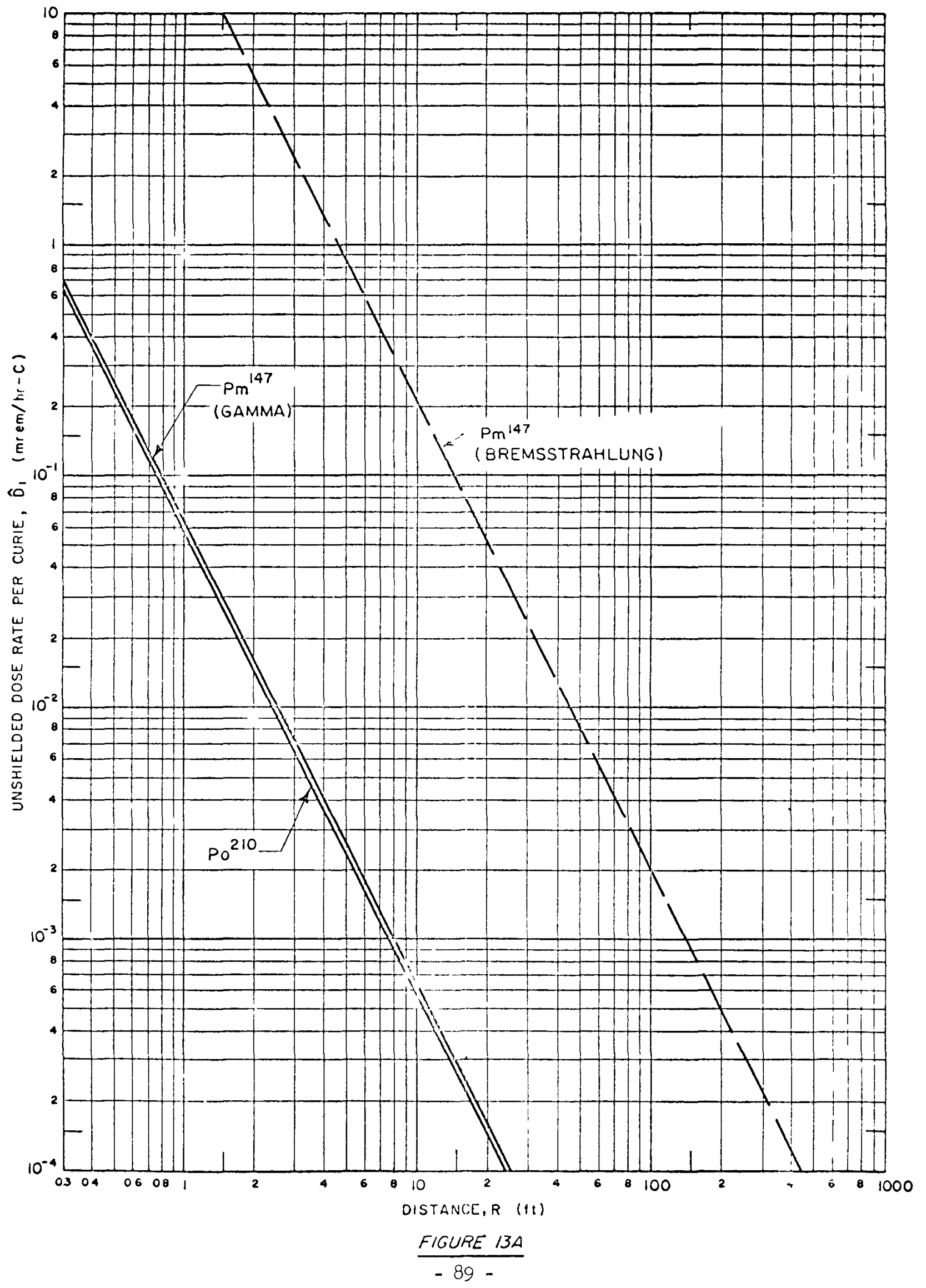




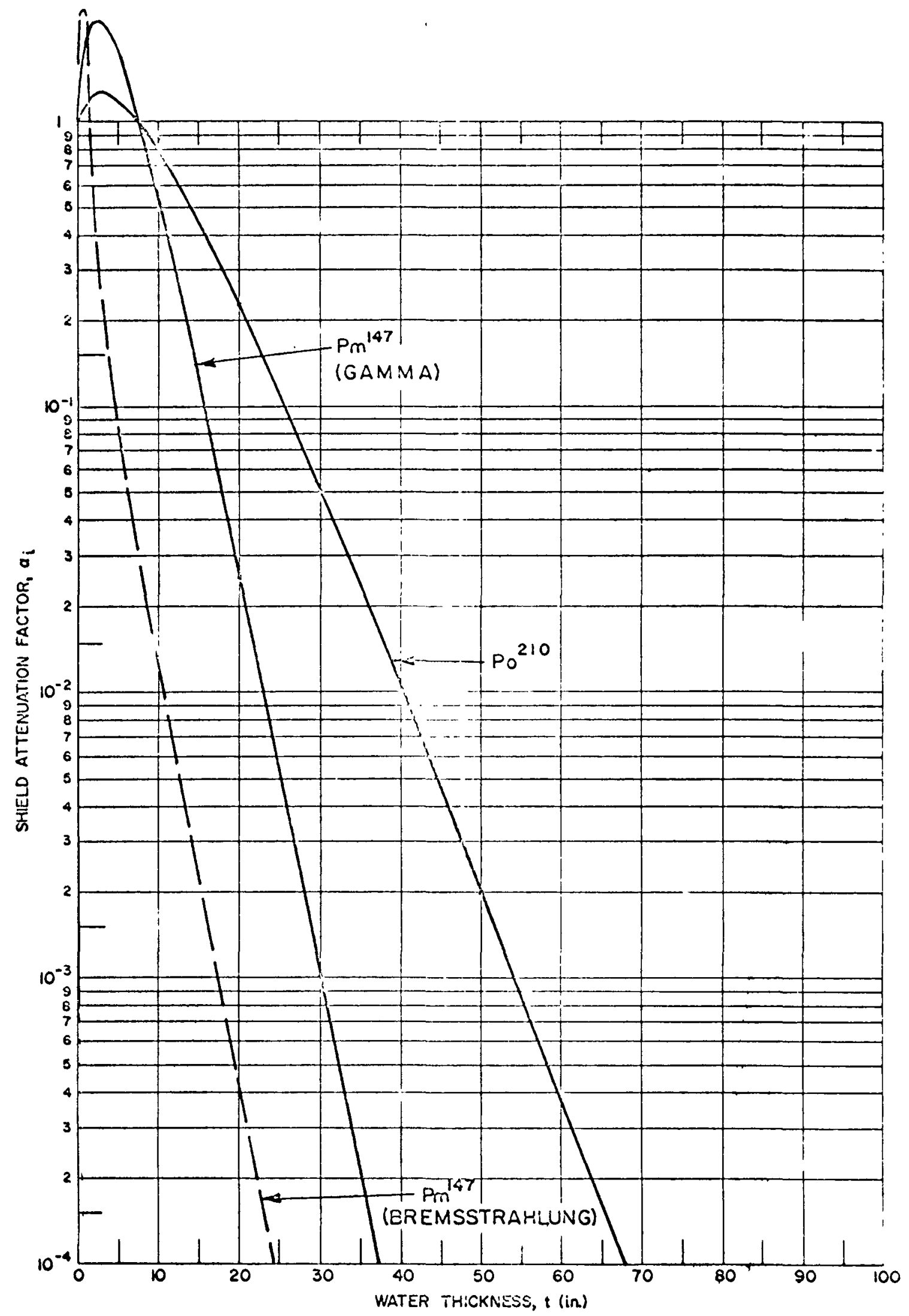

FIGURE 133 


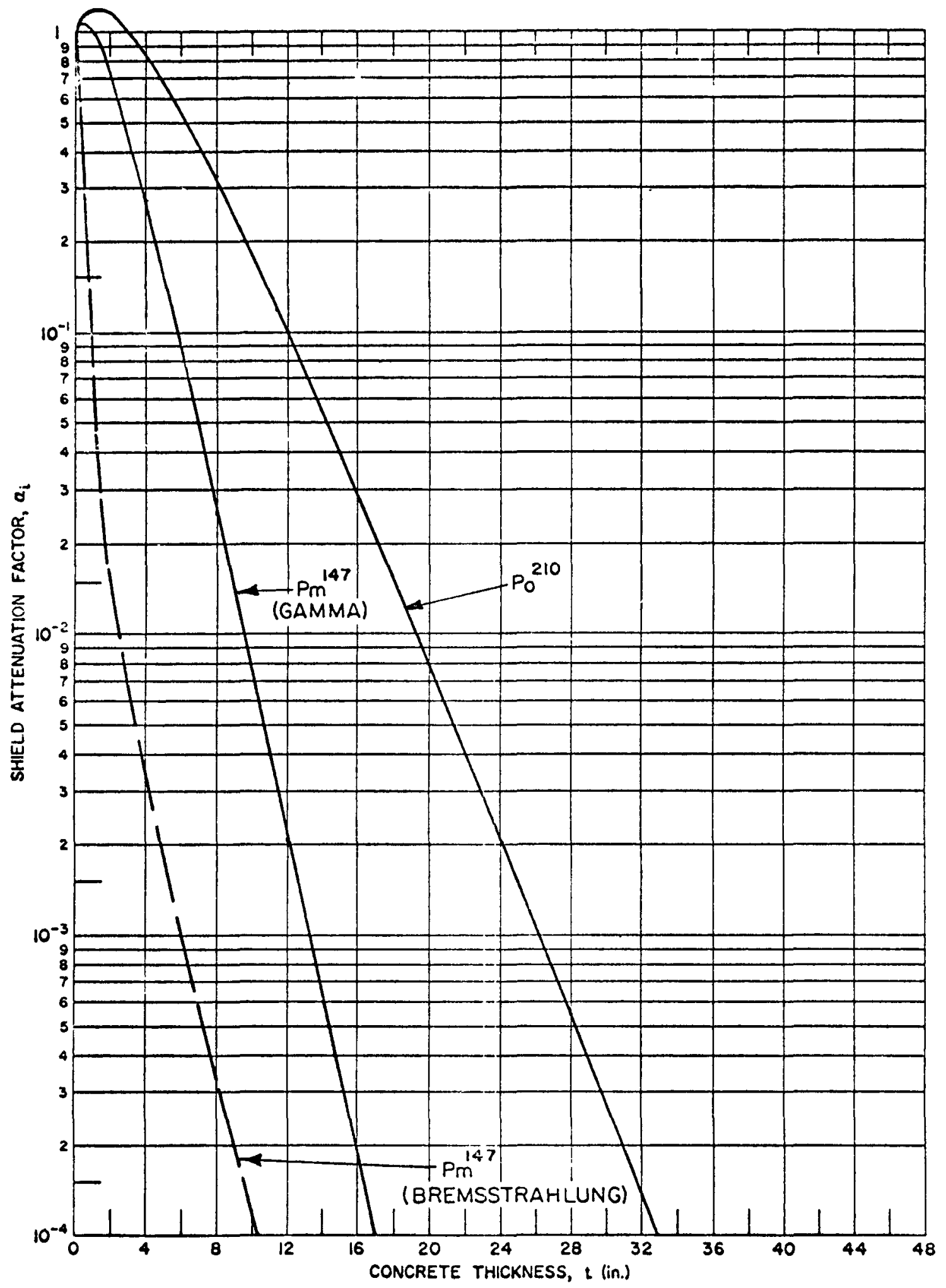

FIGURE $13 C$ 


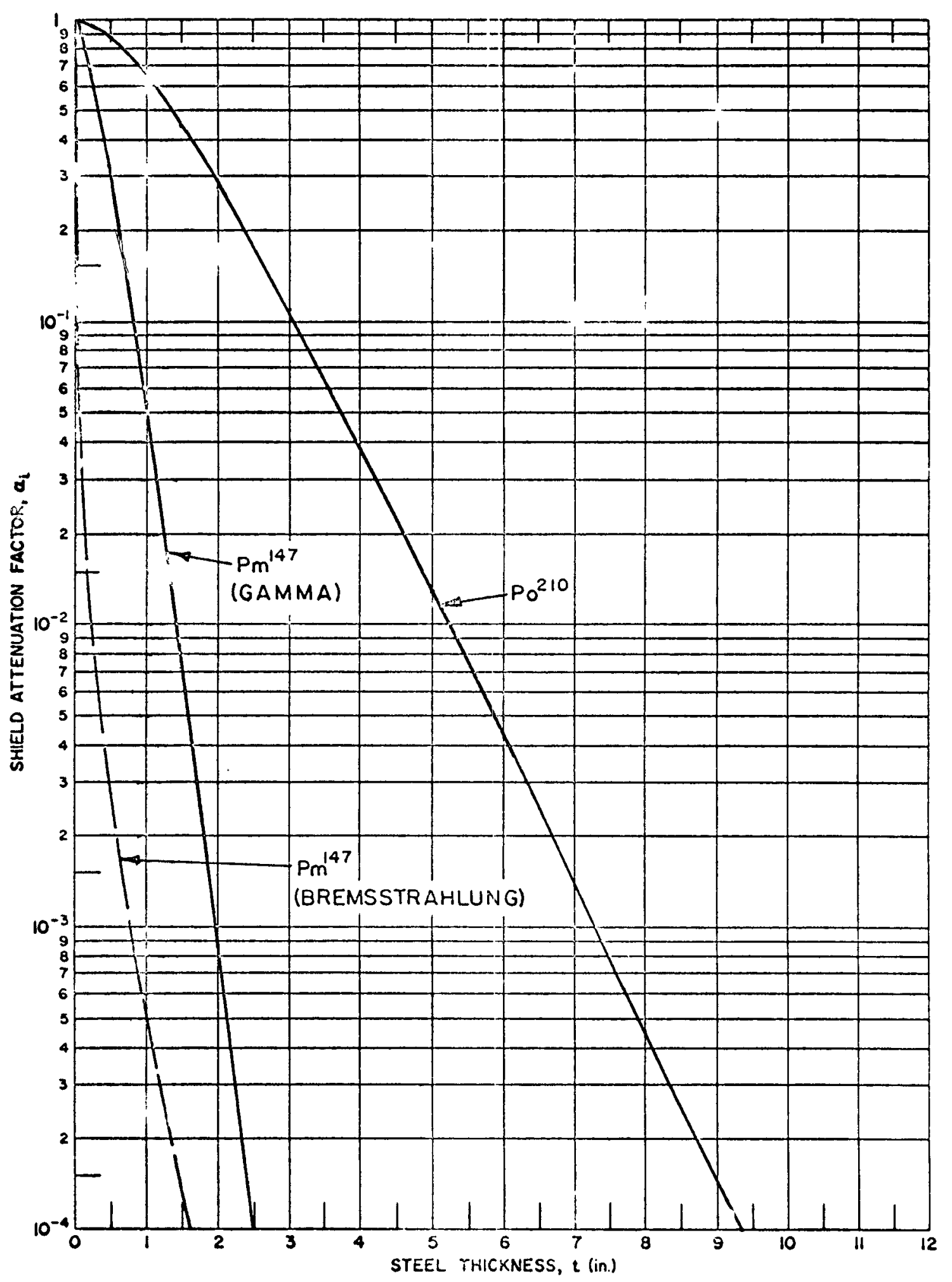

FIGURE 130 


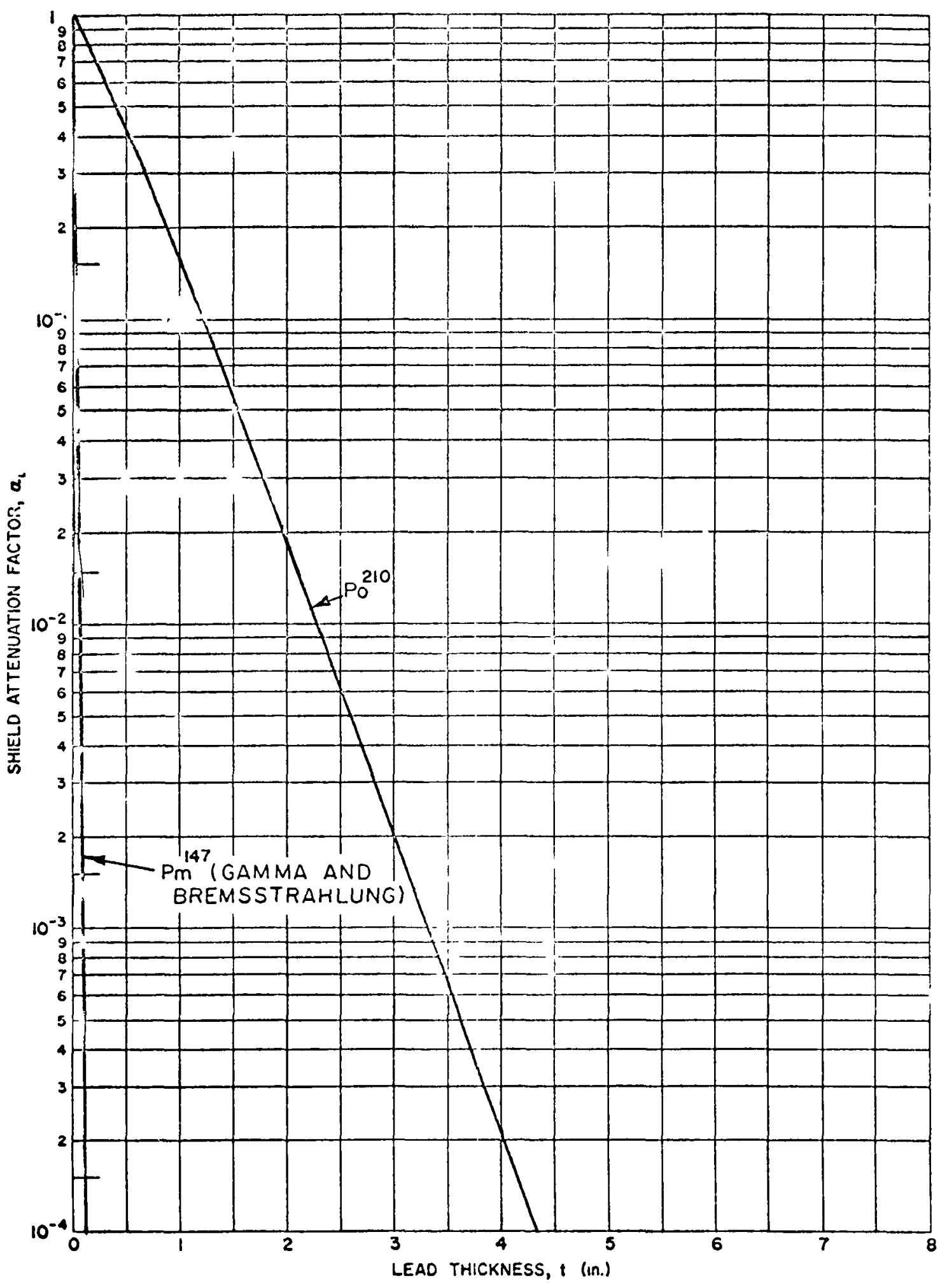

FIGURE $13 E$ 


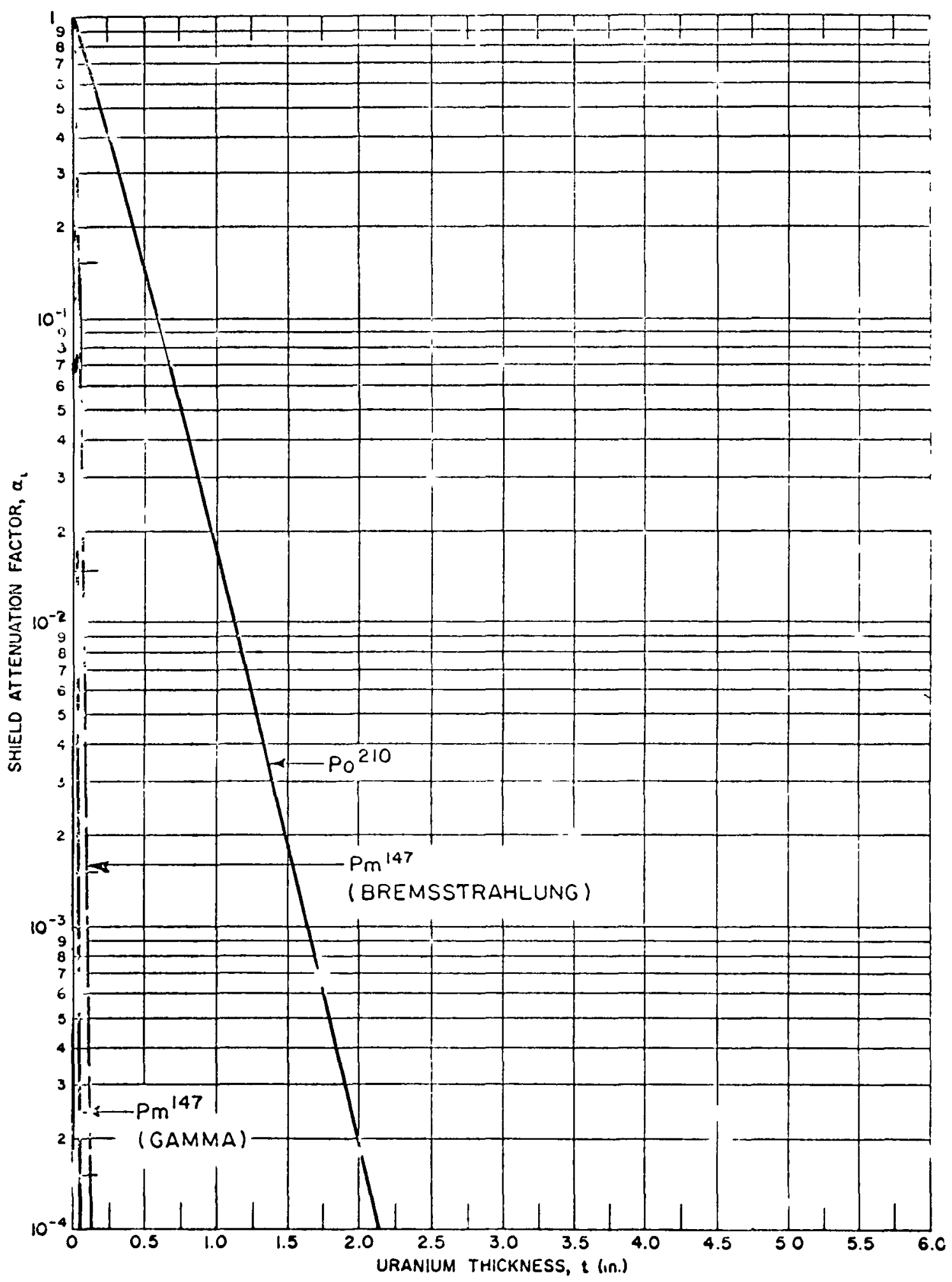

FIGURE I3F 


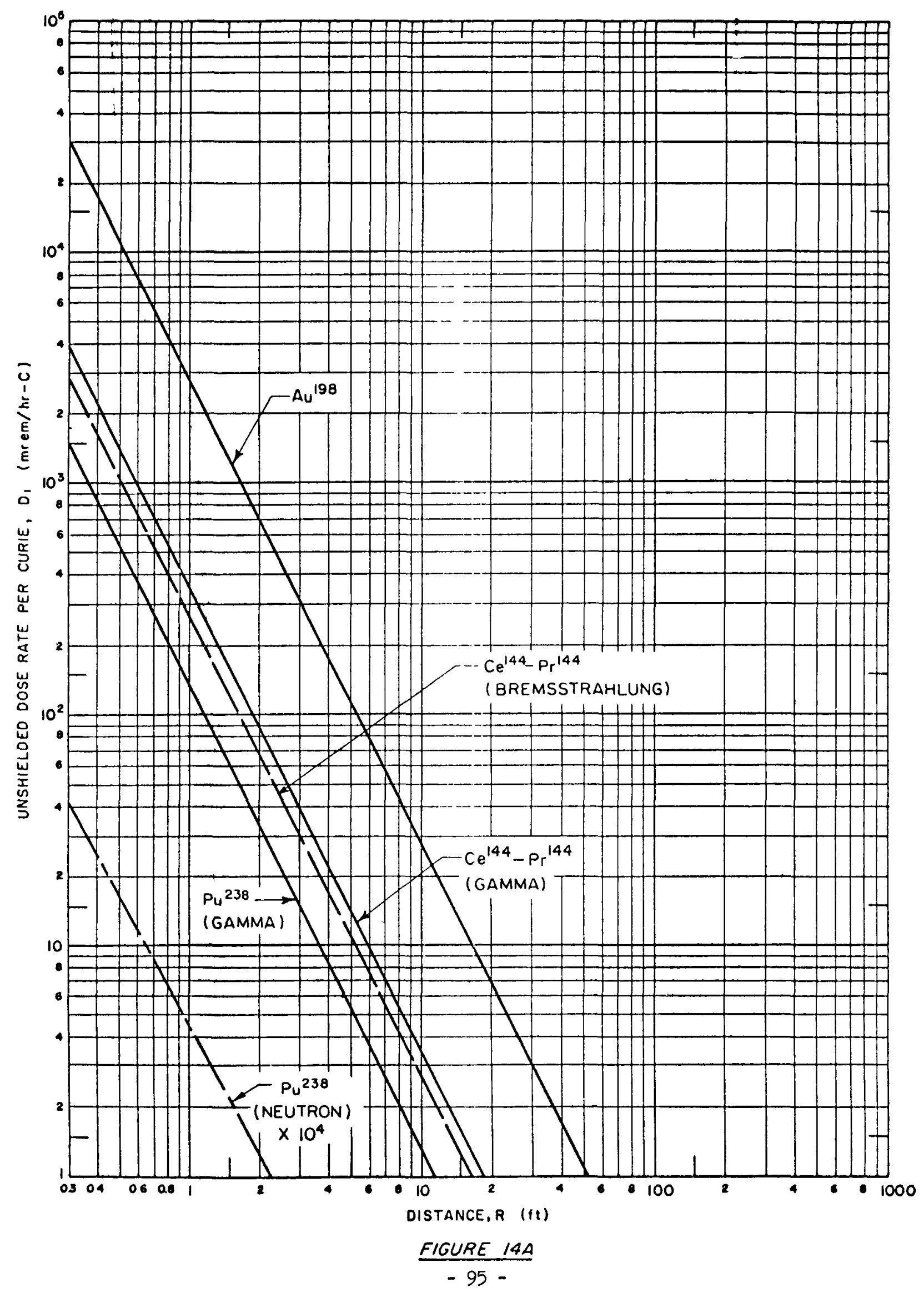




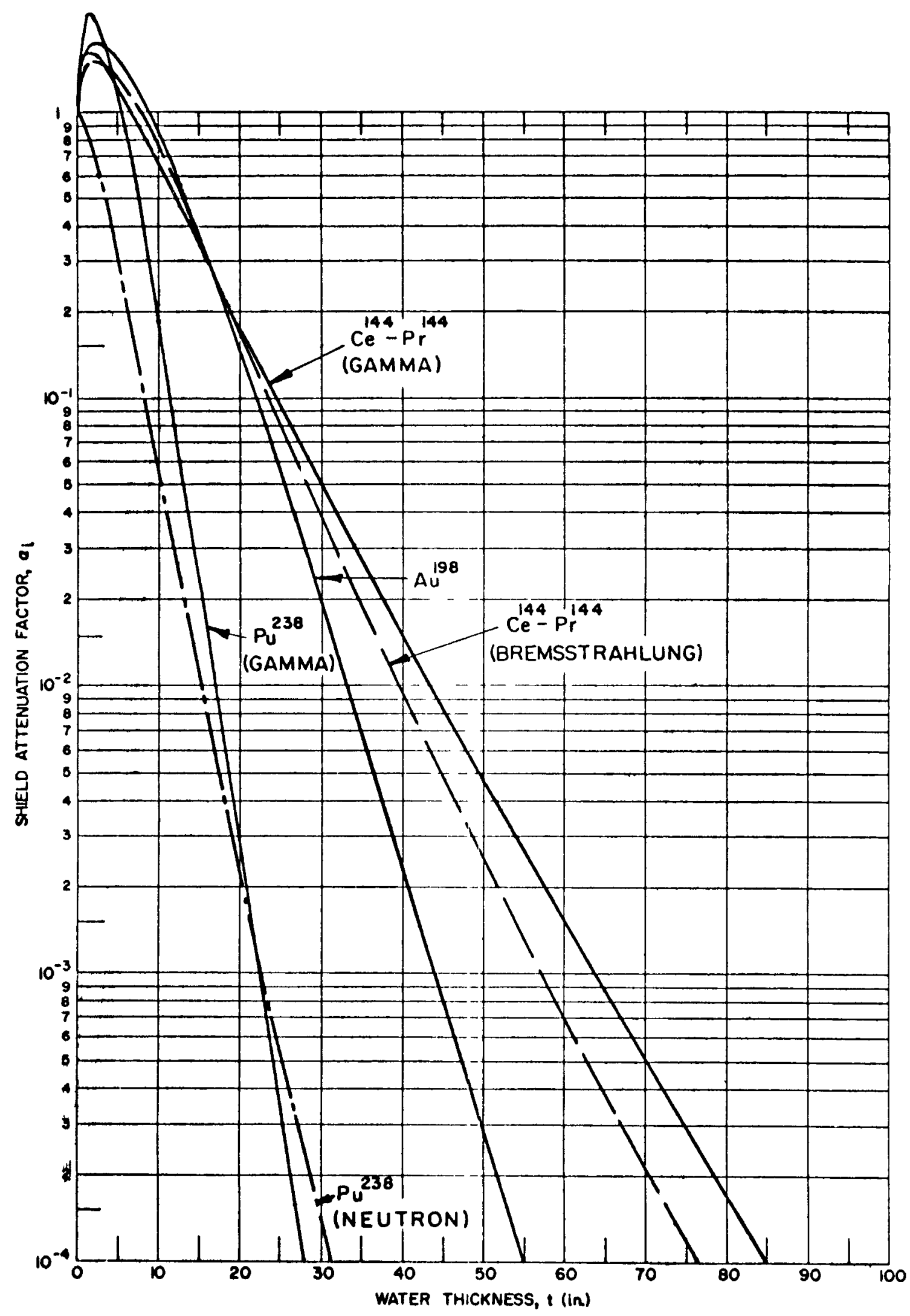

FIGURE $14 \theta$ 


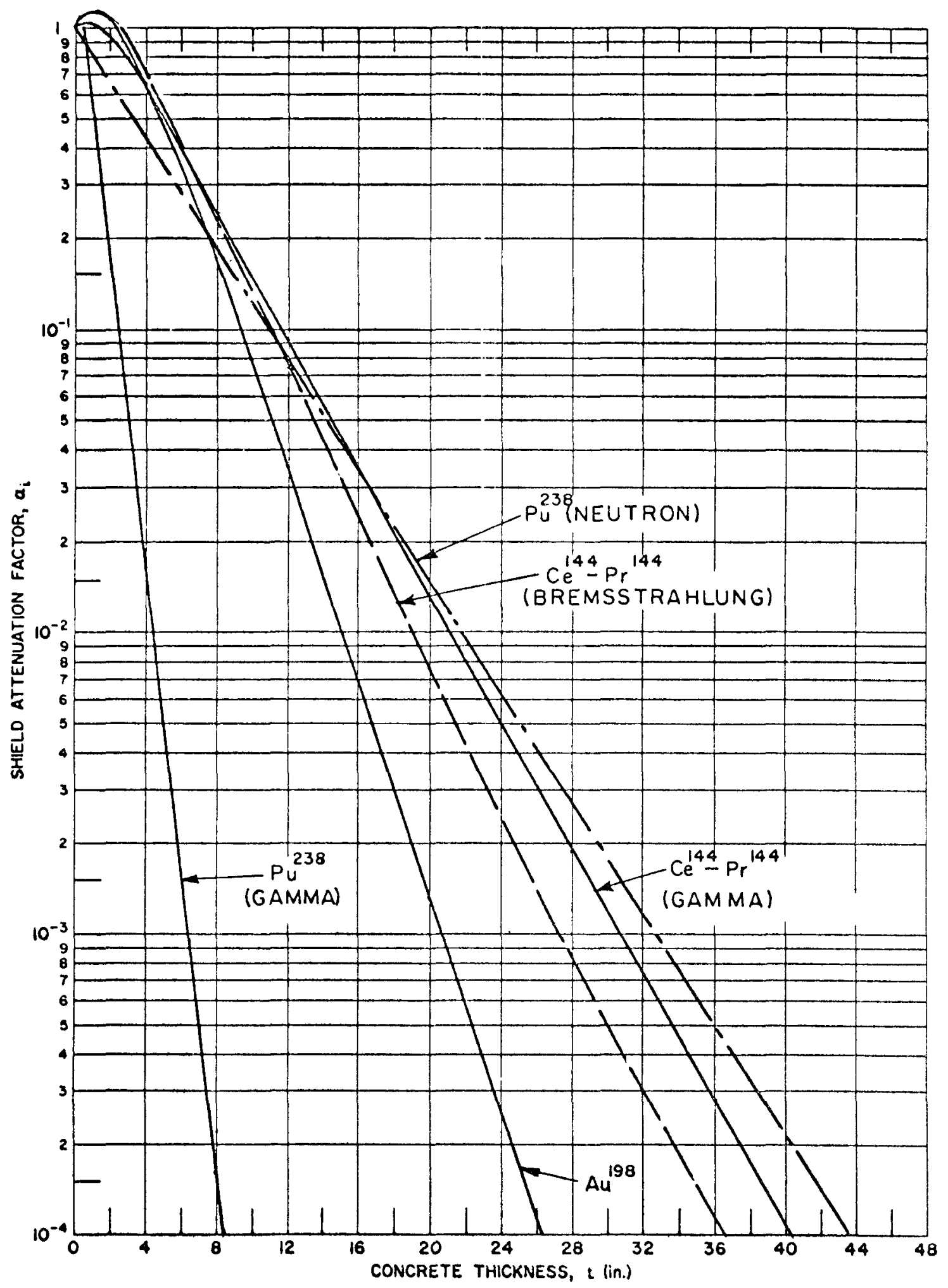

FIGURE $14 C$ 


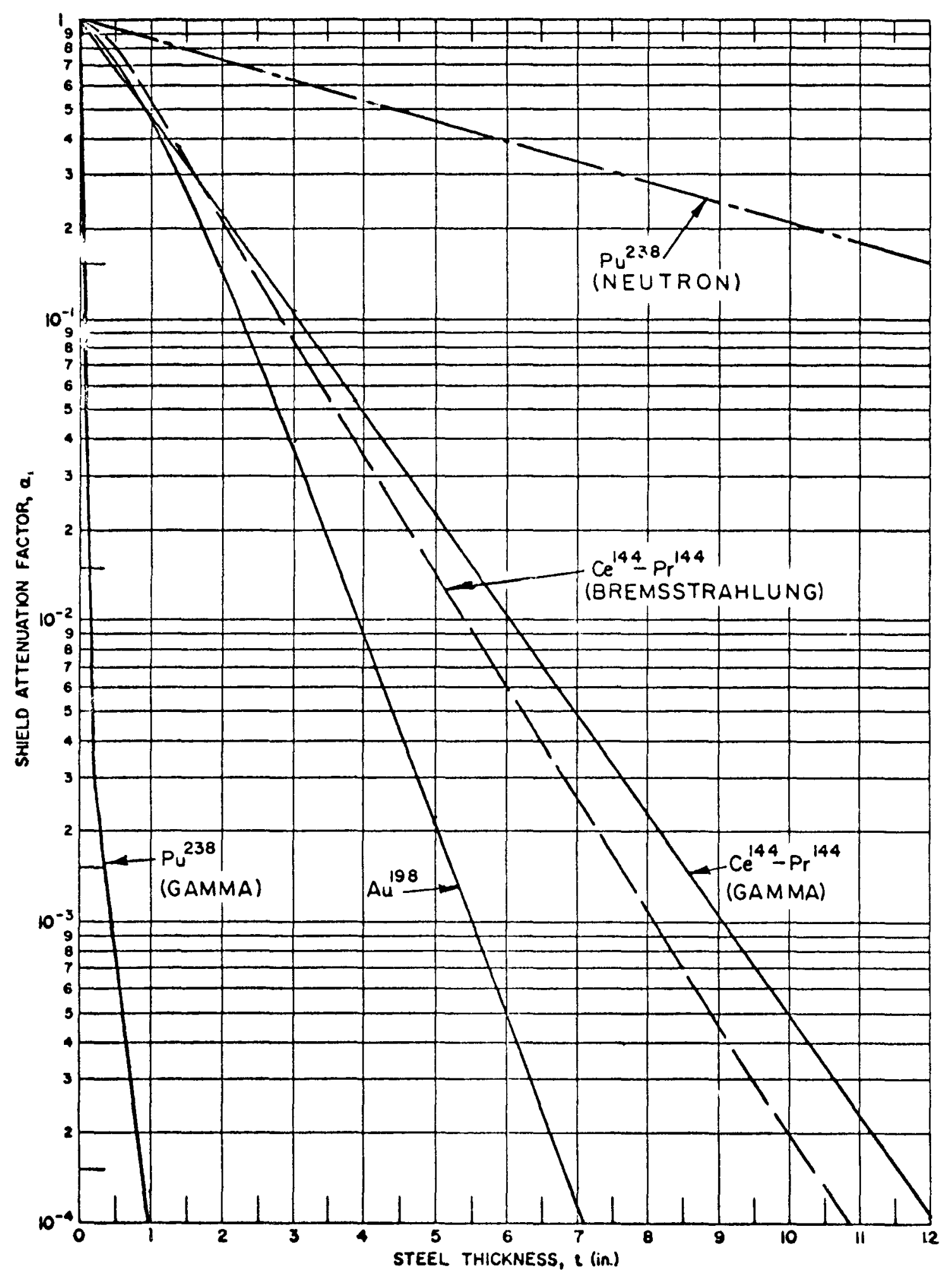

FIGURE 140 


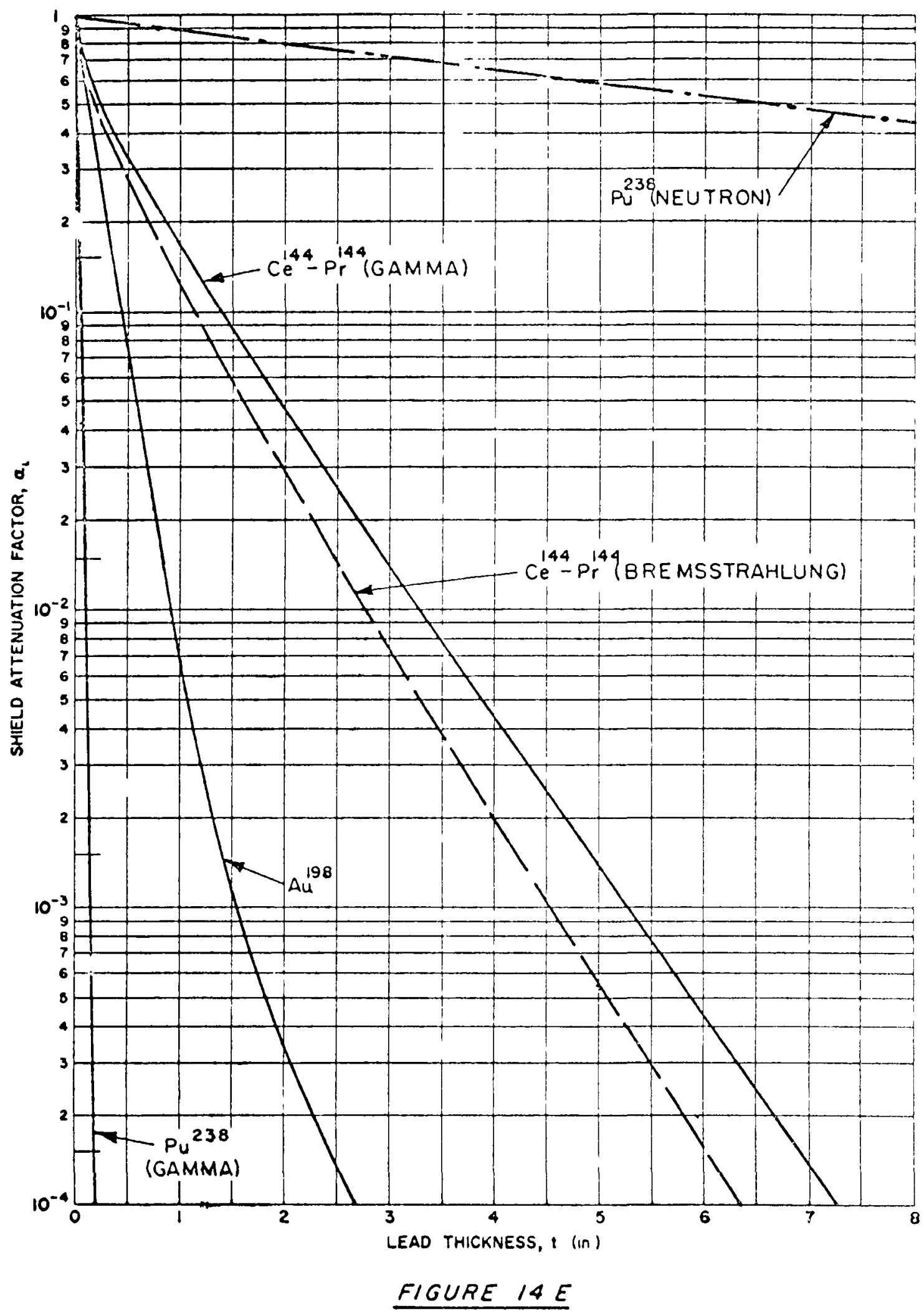




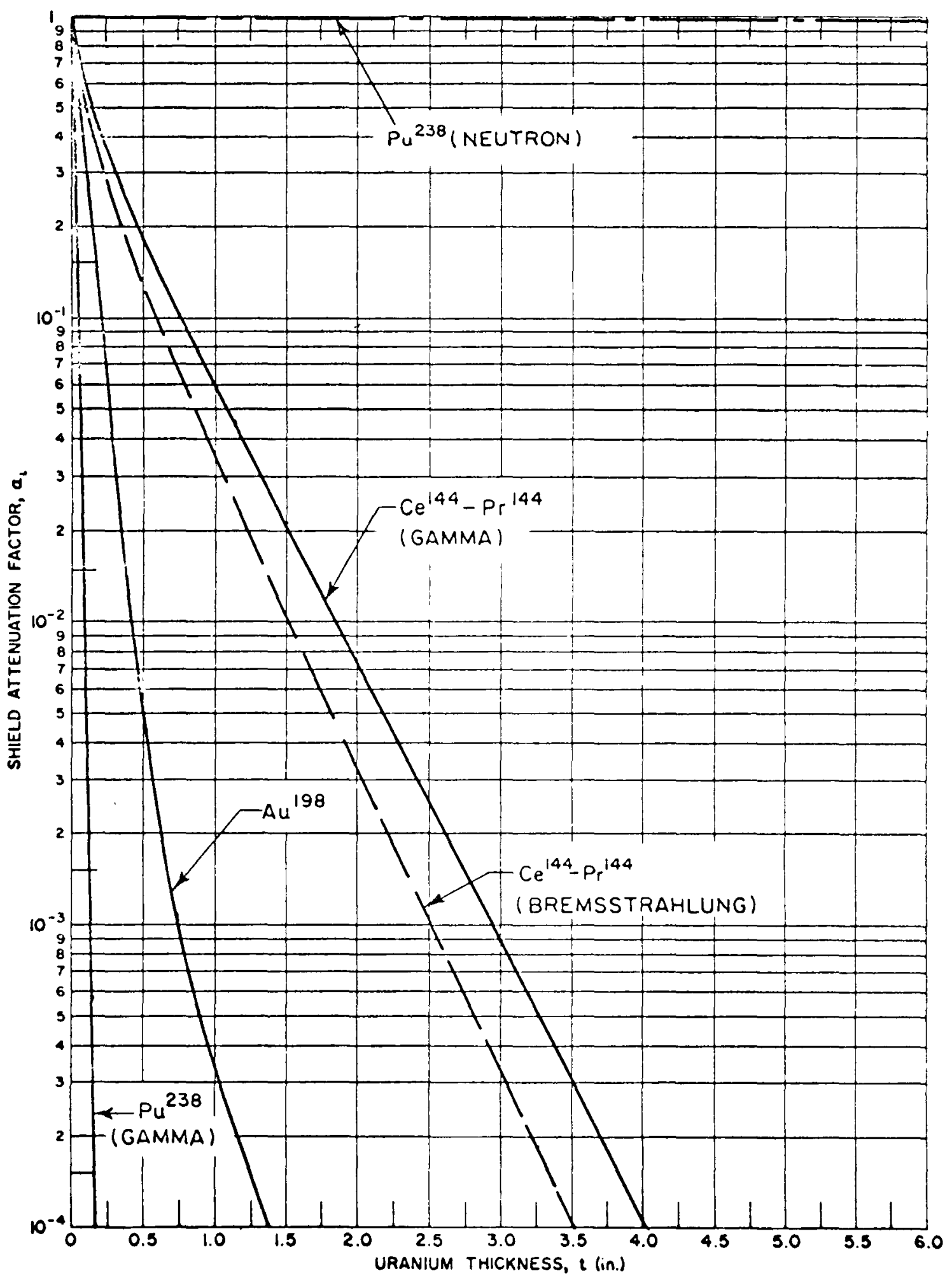

FIGURE I4F 


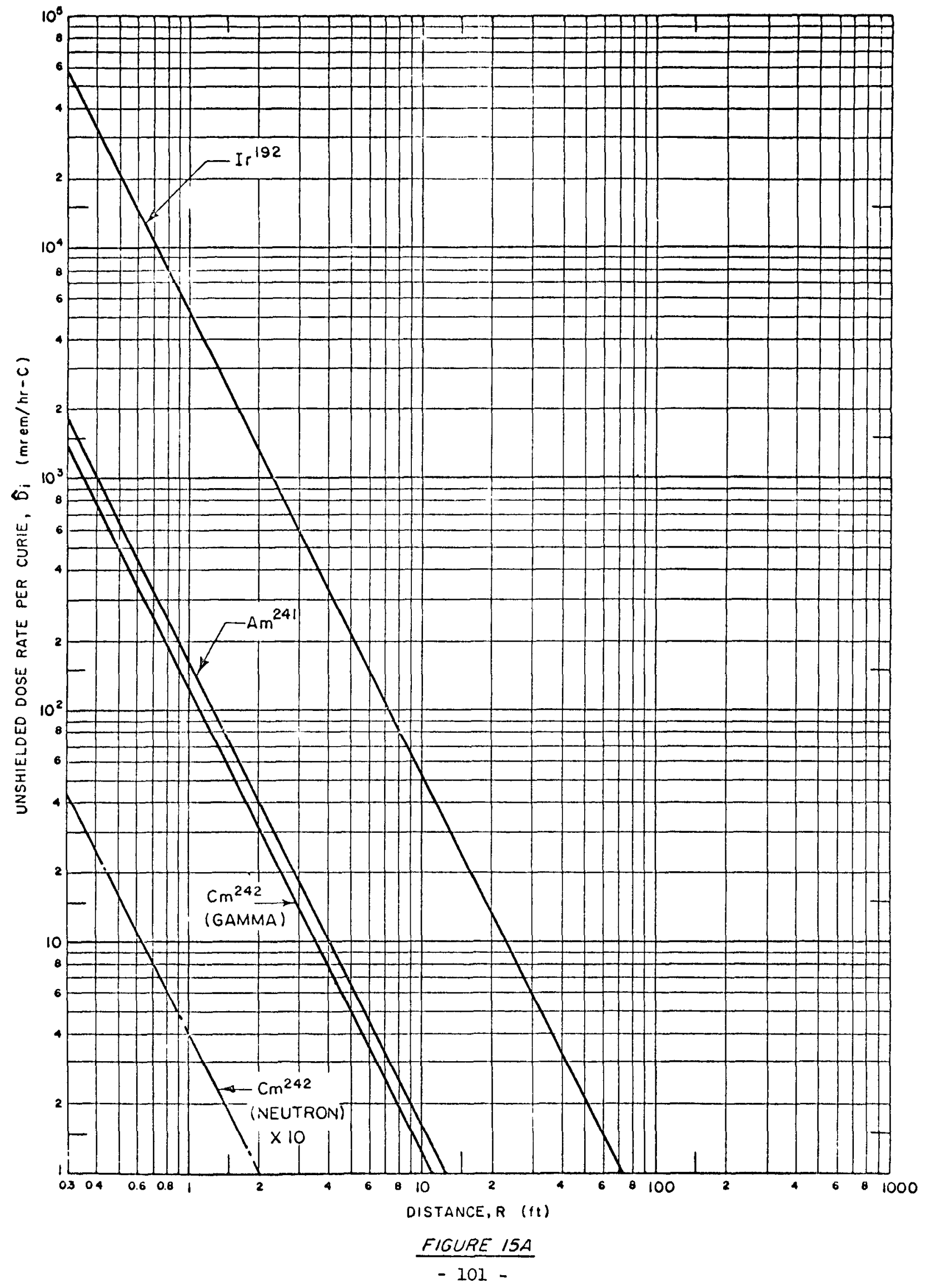




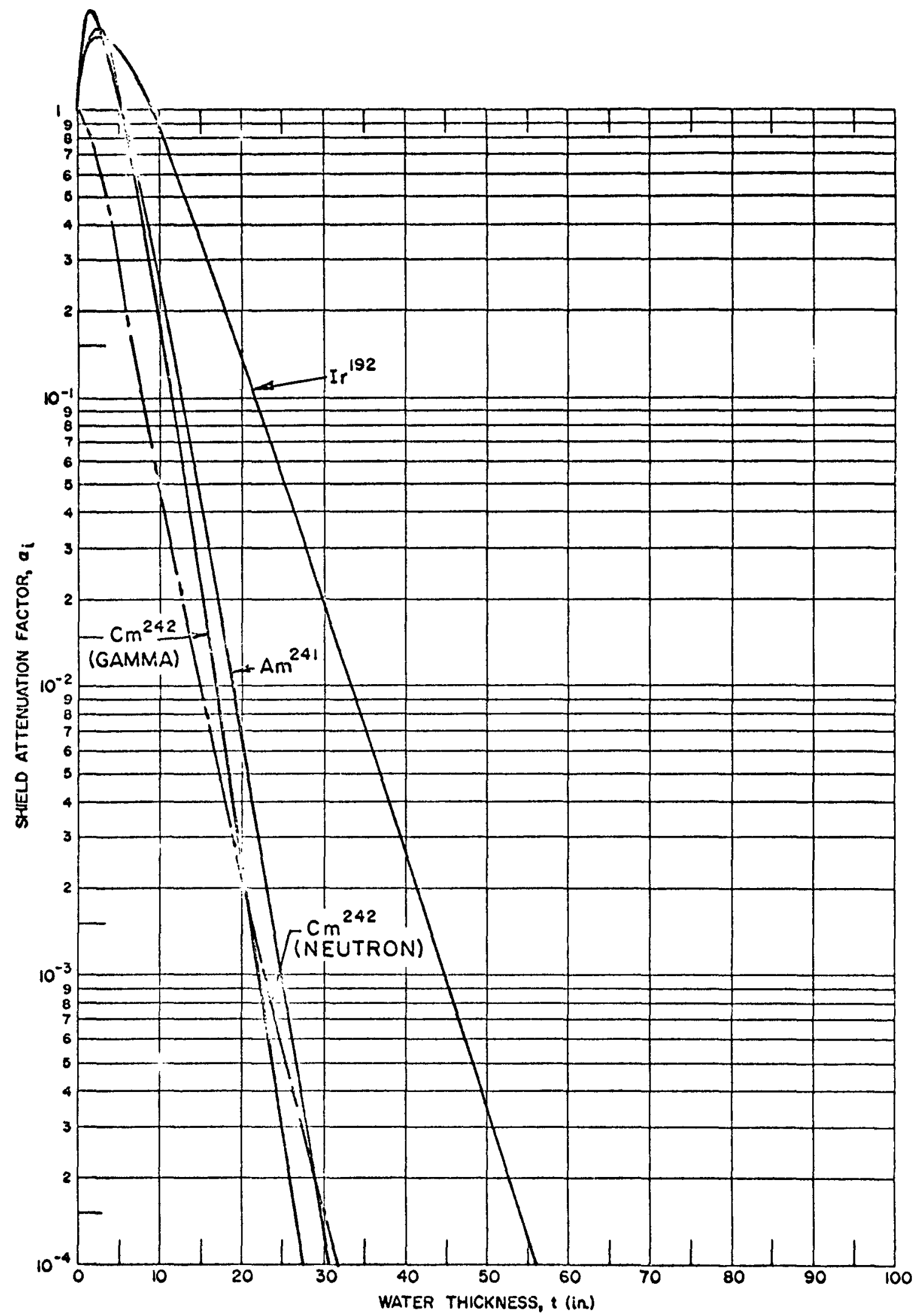

FIGURE $15 B$ 


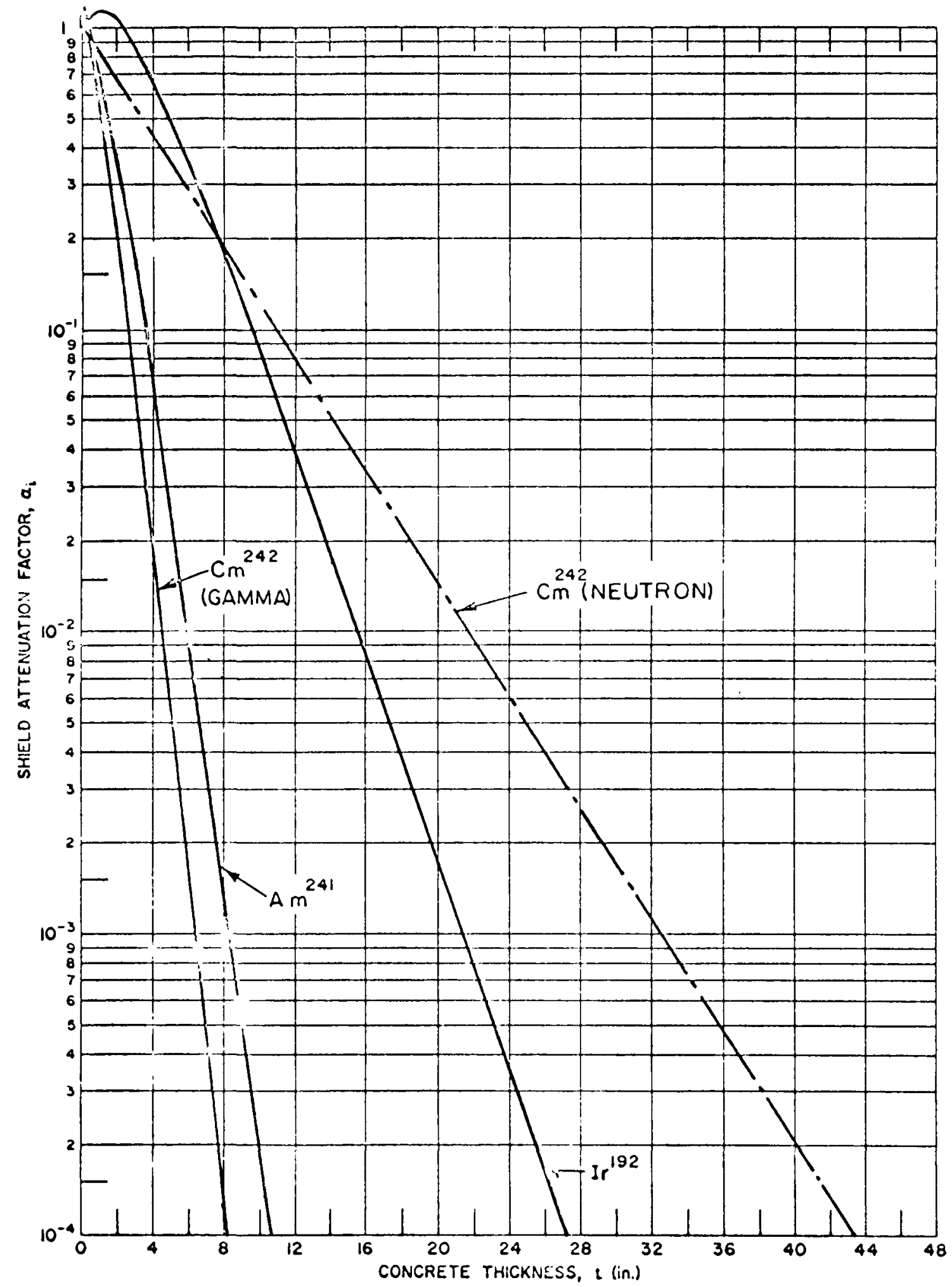

FIGURE $15 C$ 


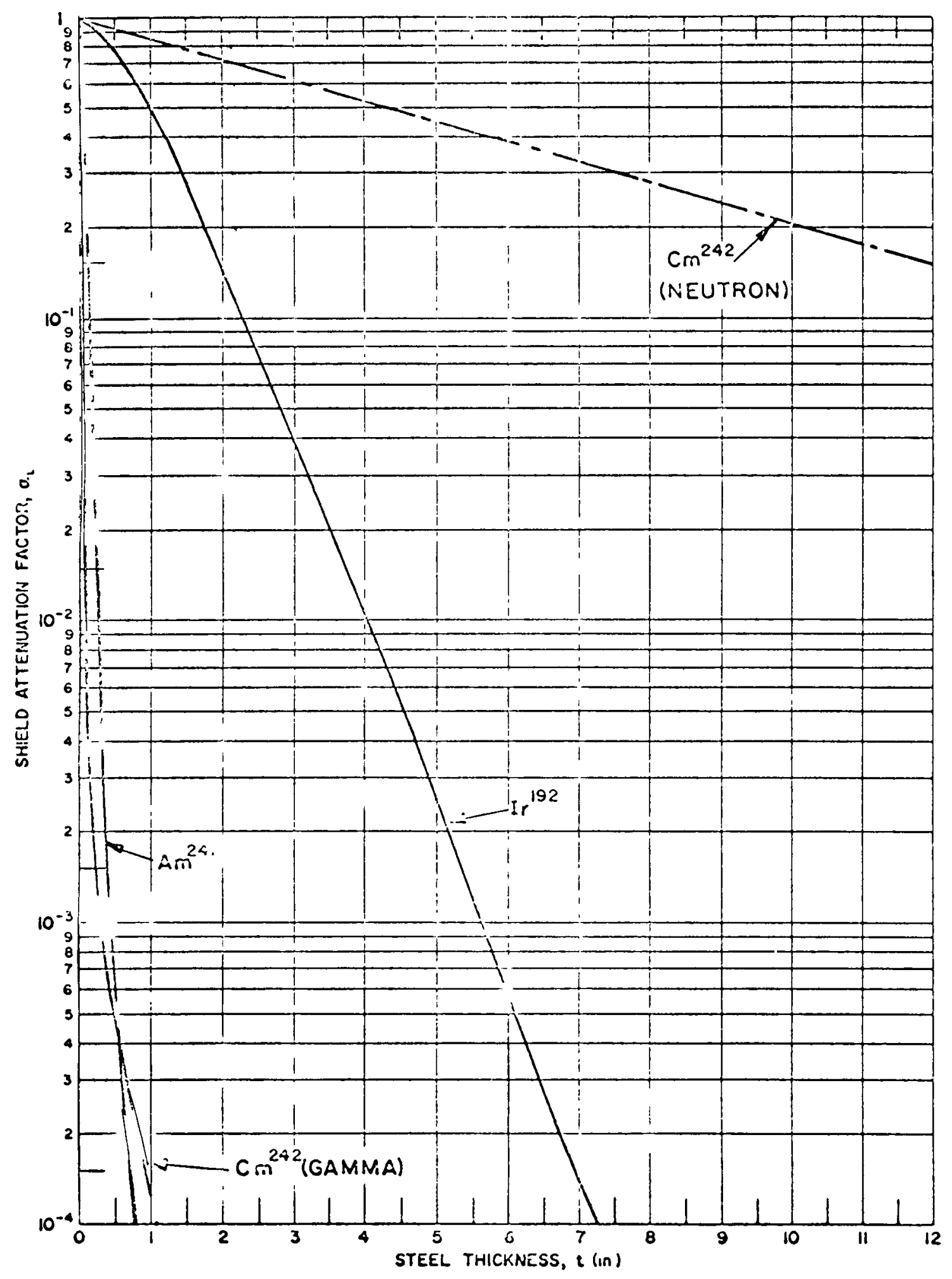

FIGURE 150 


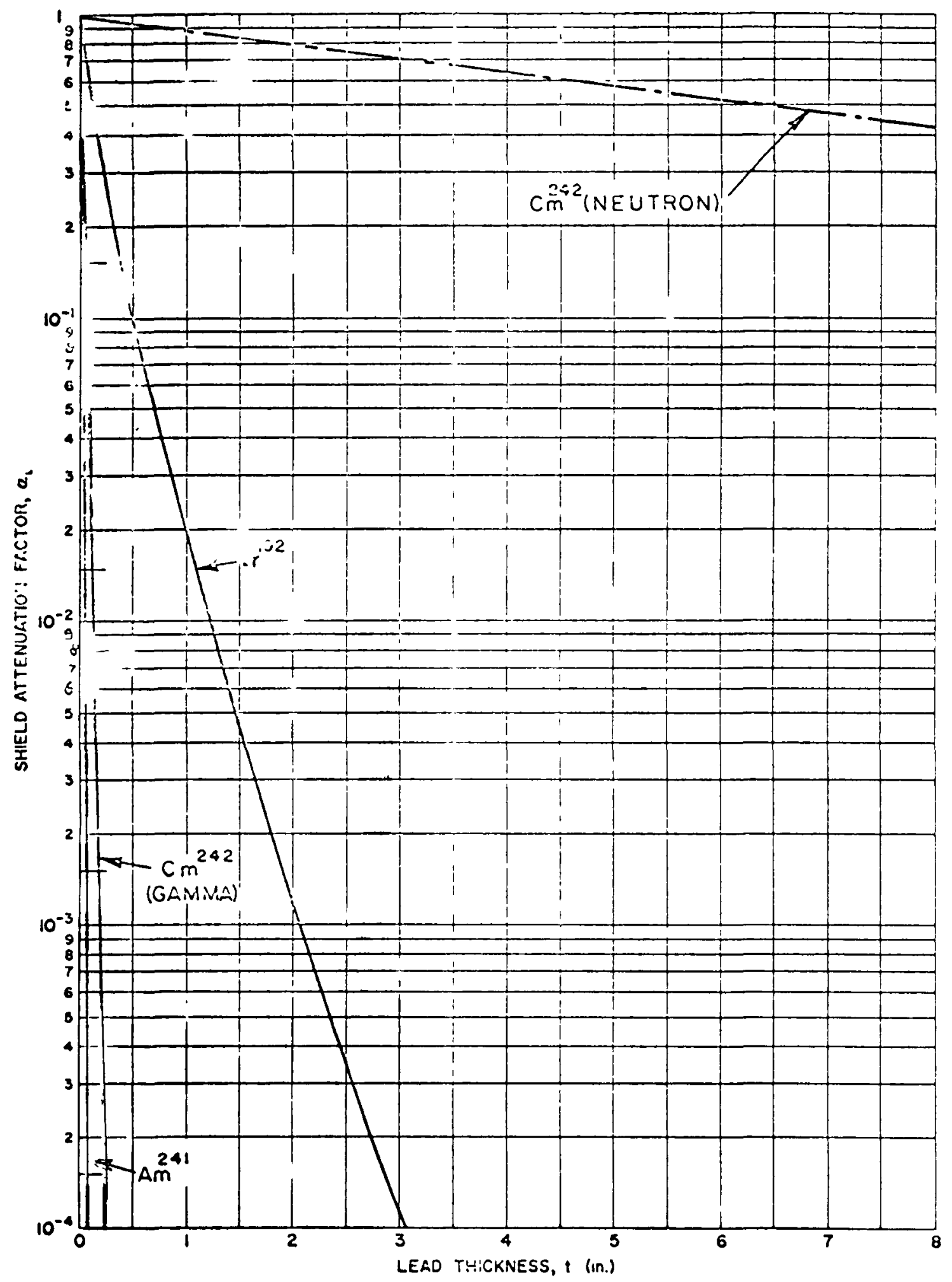

FIGURE $15 E$ 


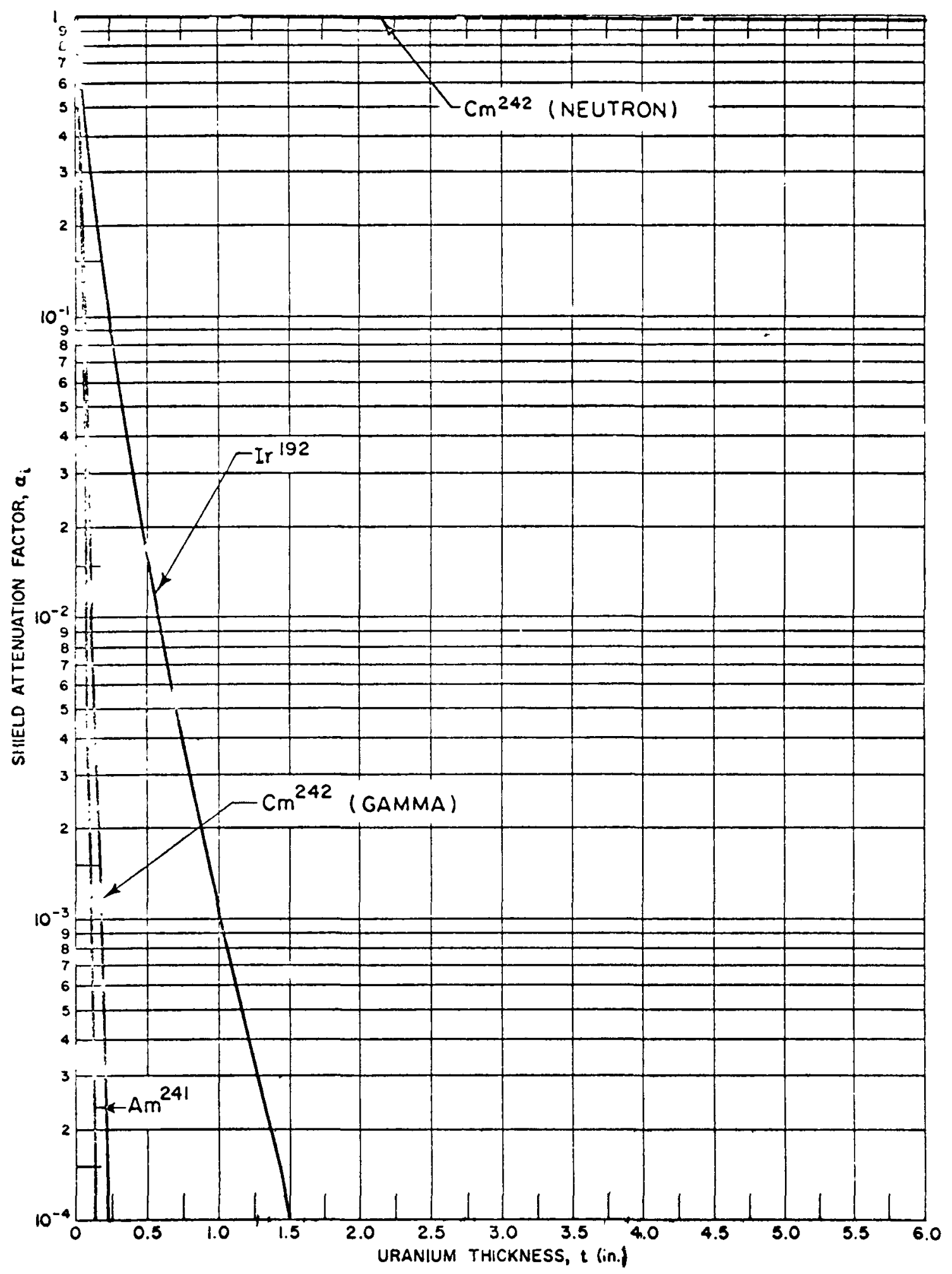

FIGURE $15 F$ 


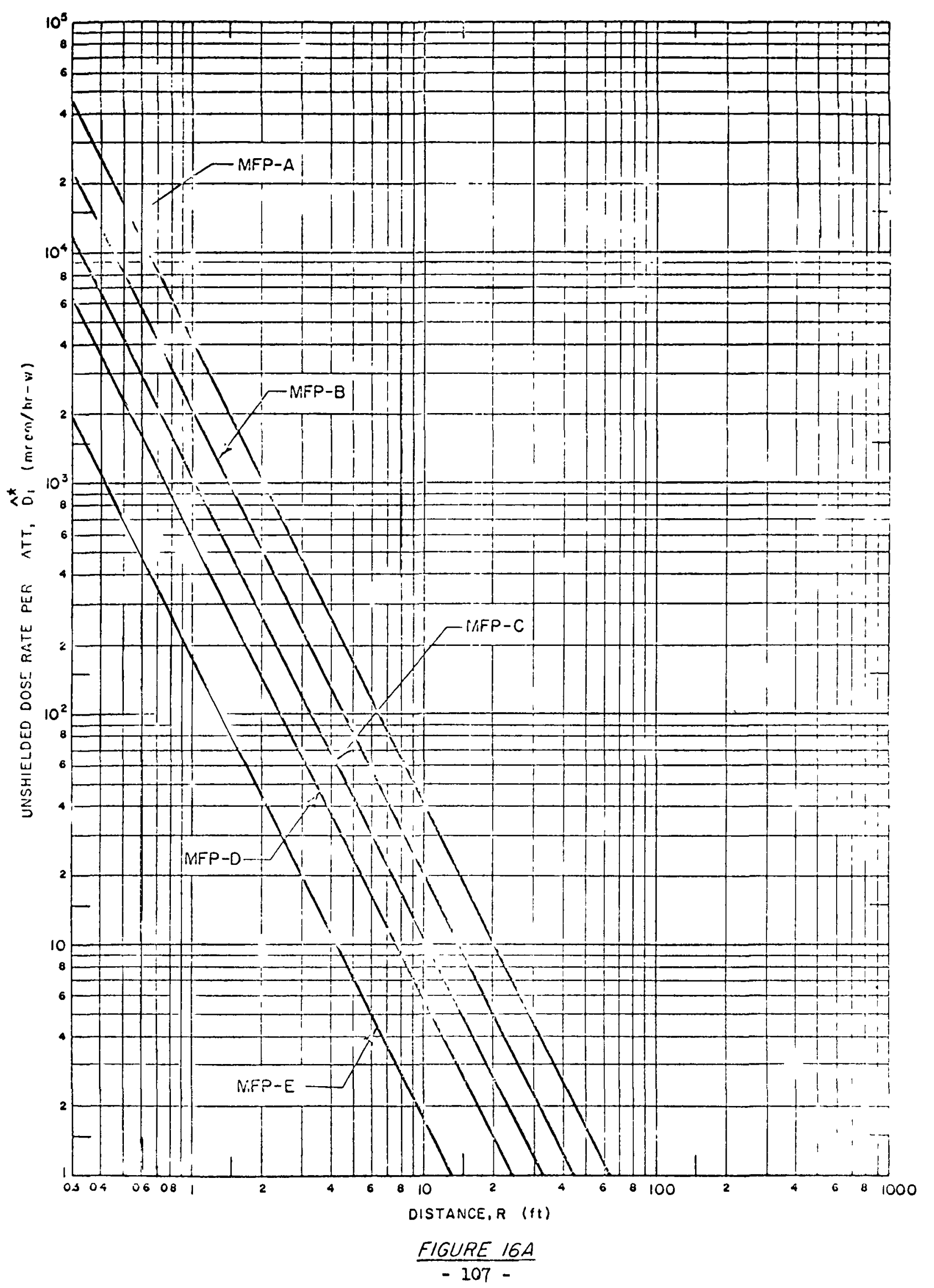




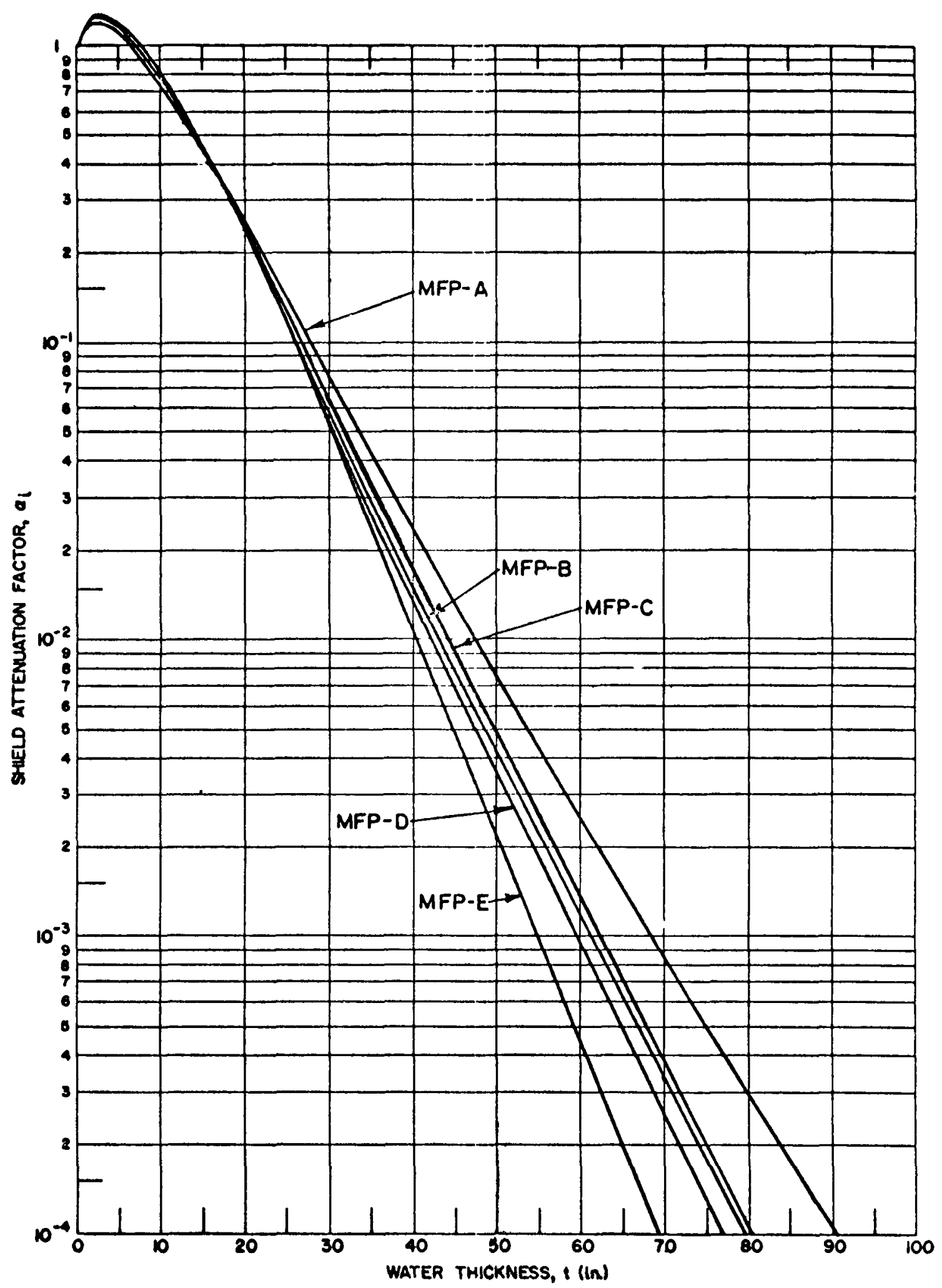

FIGURE $16 \quad B$

- 108 - 


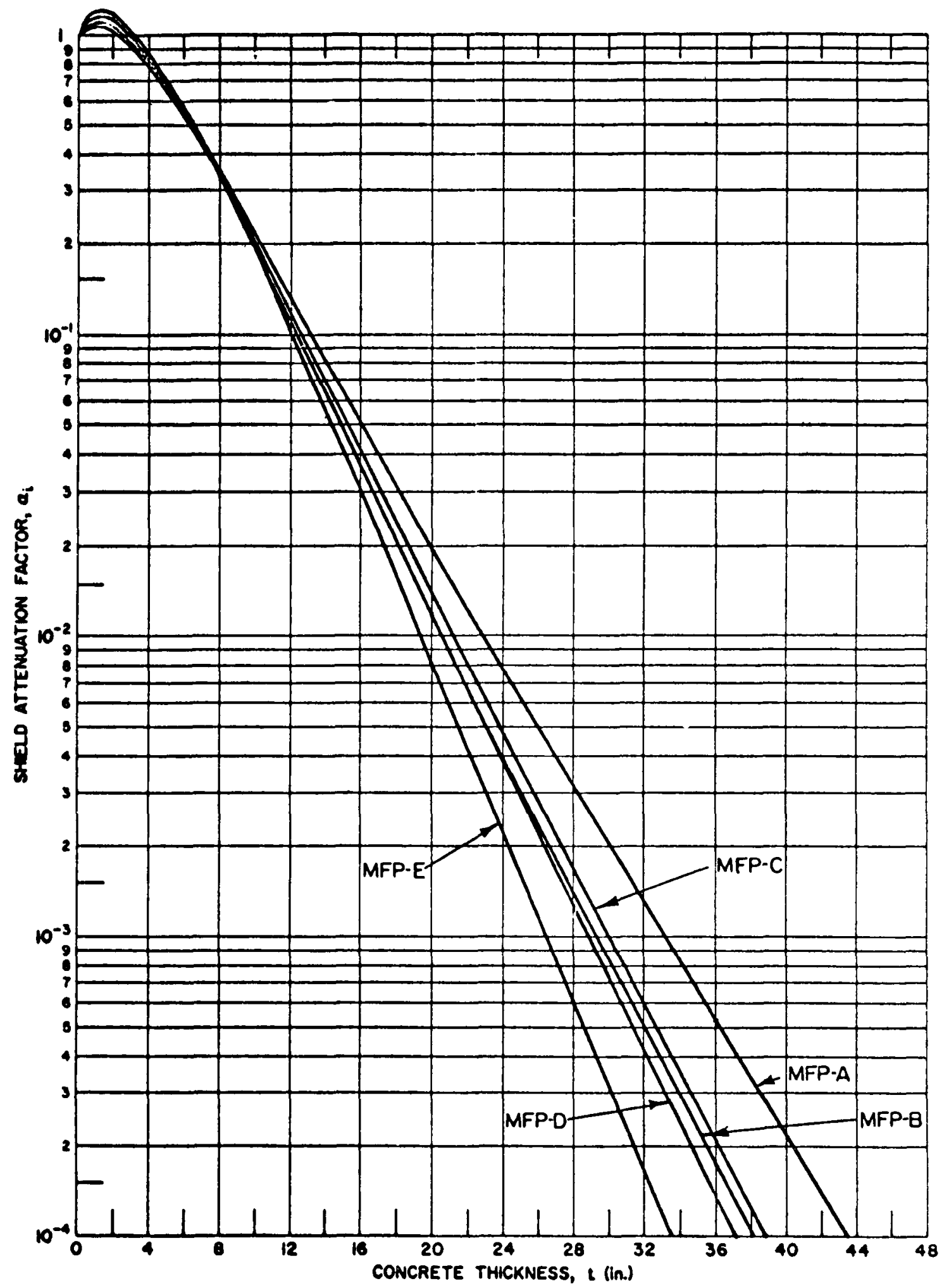

FIGURE $16 \mathrm{C}$ 


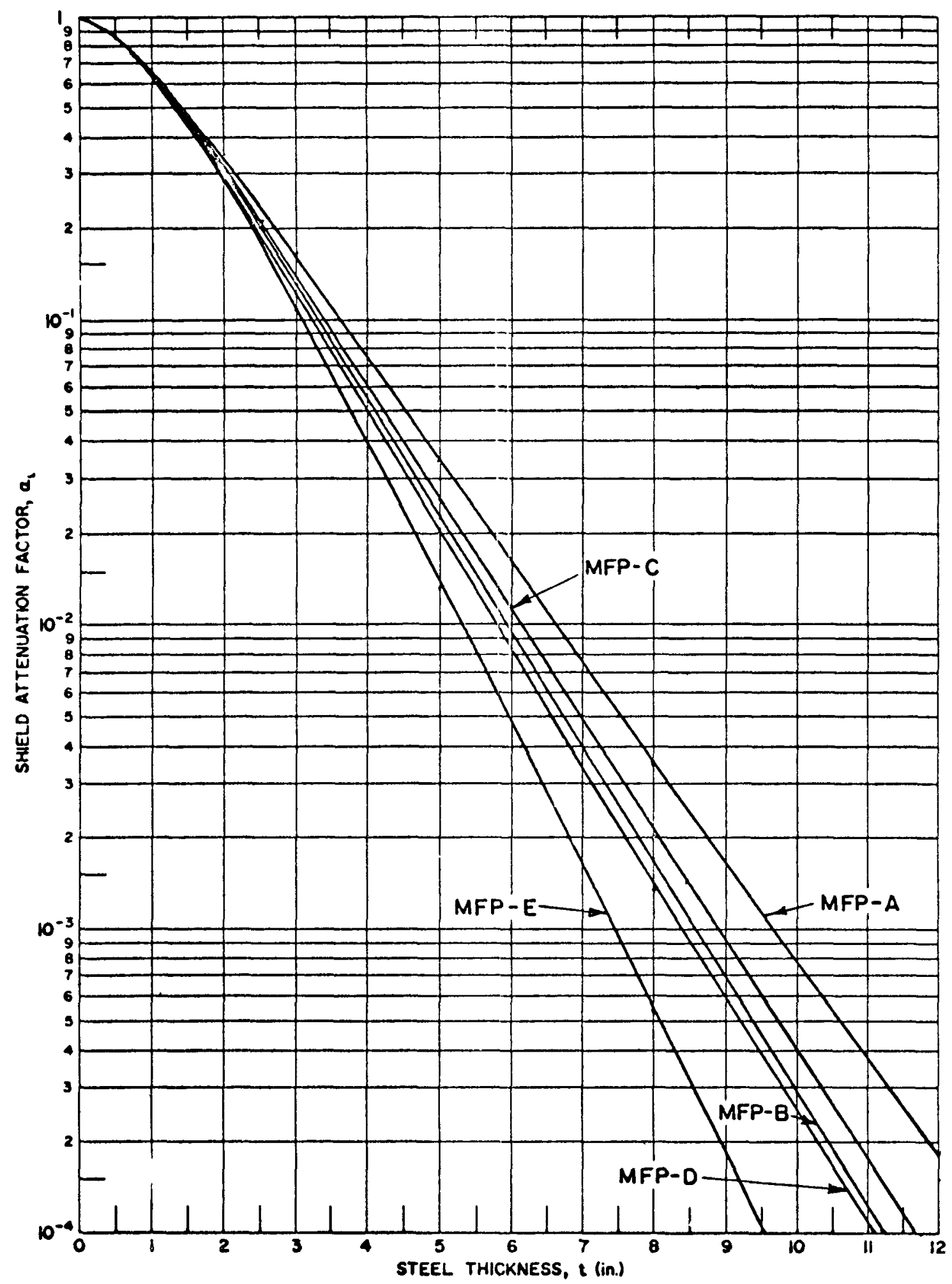

FIGURE 160

$-110-$ 


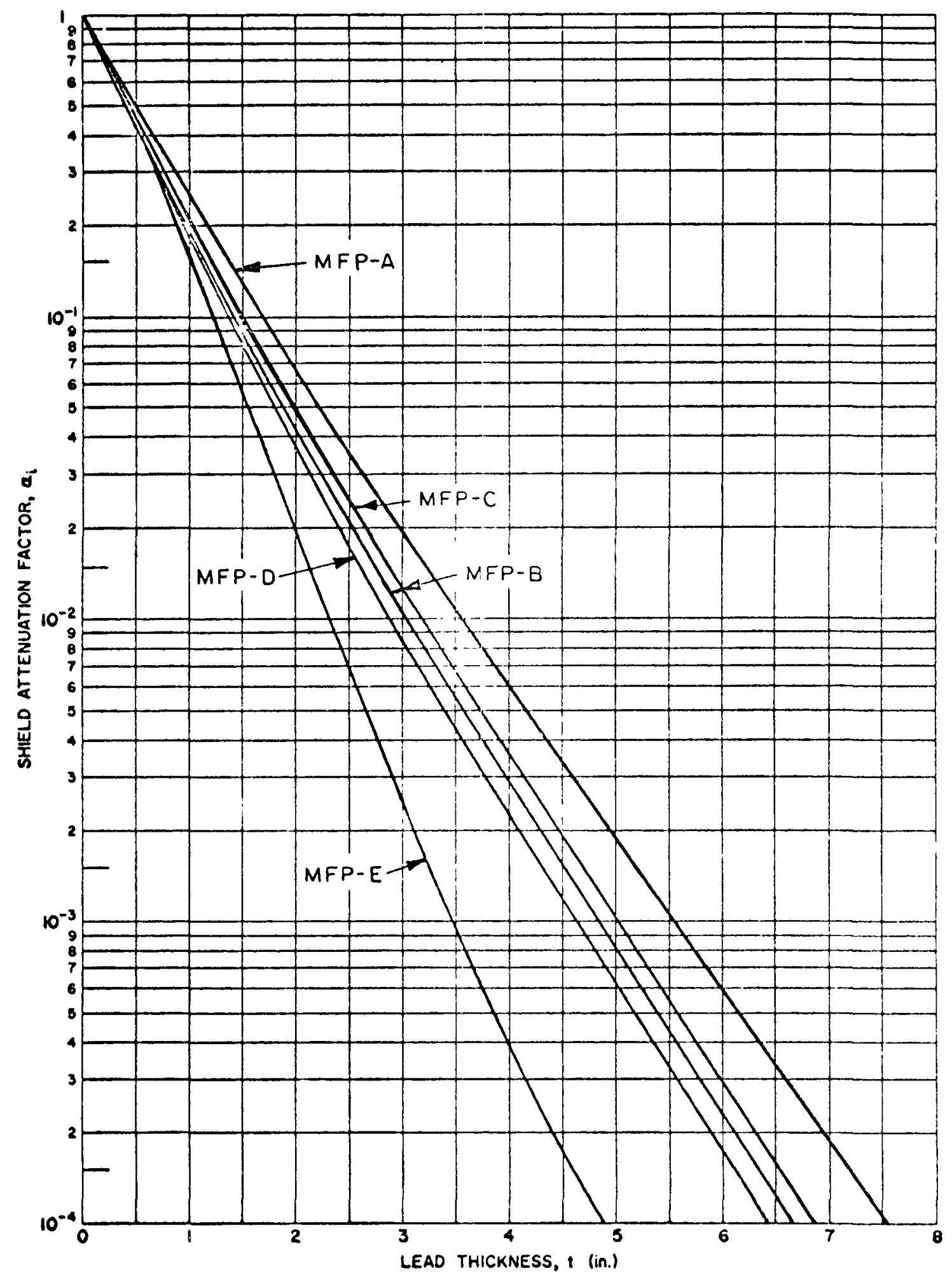

FIGURE $16 E$ 


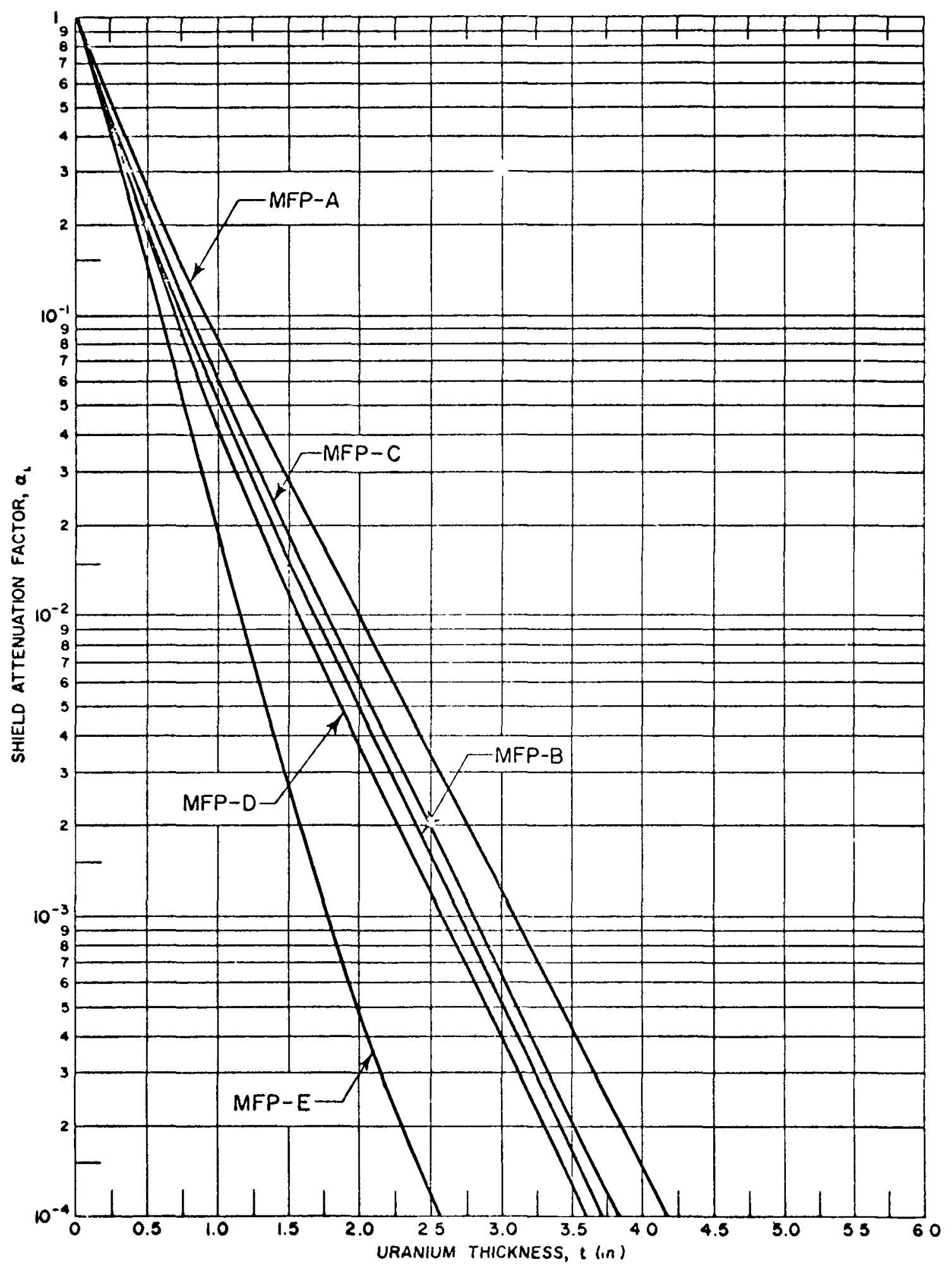

FIGLIPE $16 F$ 


\section{USE OF THE CURVES}

This section will present some examples of the use of the $\hat{D}_{i}$ and $a_{i}$ curves that appeared in the preceding section of this report.

\section{Example 1:}

What is the dose rate at six feet Irom a 500 curie co ${ }^{60}$ source shielded by nine inches of steel?

Step I: From Figure $2 \mathrm{~A}, \hat{D}_{i}=400 \mathrm{mrem} / \mathrm{hr}-\mathrm{C}$ at $\mathrm{R}=6 \mathrm{ft}$.

Step 2: The unshielded dose rate that results from a 500 curie $\mathrm{Co}^{60}$ source equals $(400)(500)=2 \times 10^{5} \mathrm{mrem} / \mathrm{hr}=200 \mathrm{rem} / \mathrm{hr}$.

Step 3: From Figure 2D, $a_{i}=9 \times 10^{-4}$ for $t=9$ in.

Step 4: Actual dose rate: $D_{i}=\hat{D}_{i} a_{i}=\left(2 \times 10^{5}\right)\left(9 \times 10^{-4}\right)=$ $180 \mathrm{mrem} / \mathrm{hr}$.

Example 2:

How much lead shielding is required around a small vial containing 250 millicuries of $\mathrm{I}^{131}$ in order not to exceed a dose rate of $0.75 \mathrm{mrem} / \mathrm{hr}$ at a distance of one yard?

Step 1: From Figure $9 \mathrm{~A}, \hat{D}_{i}=300 \mathrm{mrem} / \mathrm{hr}-\mathrm{C}$ at $\mathrm{R}=3 \mathrm{ft}$.

Step 2: The unshielded dose rate from a $250 \mathrm{mc}^{131}$ source = (300) $(.25)=75 \mathrm{mrem} / \mathrm{hr}$.

Step 3: The required dose attenuation factor is $\alpha_{i}=\frac{\text { Allowed Dose Rate }}{\text { Unshielded Dose Rate }}$ $=0.75 / 75=10^{-2}$.

Step 4: From Figure 9E, $t=1-1 / 4$ inches for $a_{i}=10^{-2}$. 
What is the unshielded dose rate at six inches from a point source containing a mixture 2000 curies of $\mathrm{Sr}^{90}$ and 600 curies of $\mathrm{Y}^{90}$ ? Assume that the beta particles are stopped in a material with $\mathrm{Z}=35$.

Step 1: From Figure 5A, $\hat{D}_{i}=24 \mathrm{mrem} / \mathrm{hr}-\mathrm{C}$ for $\mathrm{Sr}^{90}$ and $\hat{D}_{i}=260 \mathrm{mrem} / \mathrm{hr}-\mathrm{C}$ for $\mathrm{Y}^{90}$, at $\mathrm{R}=0.5 \mathrm{ft}$.

Step 2: Correction for $\mathrm{Z}=35$ :

$$
\begin{aligned}
& \hat{\mathrm{D}}_{i}(\text { corrected })=24\left(\frac{35}{26}\right)=32.3 \mathrm{mrem} / \mathrm{hr}-\mathrm{C} \text { for } \mathrm{Sr}^{90} \\
& \hat{\mathrm{D}}_{i}(\text { corrected })=260\left(\frac{35}{26}\right)=350 \mathrm{mrem} / \mathrm{hr}-\mathrm{C} \text { for } \mathrm{Y}^{90} .
\end{aligned}
$$

Step 3: Actual dose rate: $D_{i}=(32.3)(2000)+(350)(600)=$ $2.7 \times 10^{5} \mathrm{mrem} / \mathrm{hr}=270 \mathrm{rem} / \mathrm{hr}$.

Example 4:

Depleted uranium is used as a shield for transporting spent fuel elements. What shield thickness is required to limit the dose rate at ten feet to $2.5 \mathrm{mr} / \mathrm{hr}$, when the source is a group of four fuel elements that have been discharged from reactor that had been operating at a power level of 60 Mwt? The reactor core contains 800 such fuel elements, and one month has elaspsed since the fuel elements were removed from the reactor.

Step 1: From Figure 16A for MFP-D, $\hat{D}_{i}^{*}=5.8 \mathrm{mrem} / \mathrm{hr}$-watt for $\mathrm{R}=10 \mathrm{ft}$.

Step 2: The operating power level for the group of four fuel elements is $P=\frac{(4)(60)}{(800)}=0.3 \mathrm{Mw}$.

Step 3: The unshielded dose rate is $\hat{\mathrm{D}}_{i}^{*} \mathrm{P}=(5.8)\left(3 \times 10^{5}\right)=$ $1.74 \times 10^{6} \mathrm{mrem} / \mathrm{hr}$. 
Step 4: The required dose attenuation factor is

$$
\alpha_{1}=\frac{2.5}{1.74 \times 10^{6}}=1.4 \times 10^{-6} \text {. }
$$

Step 5: From Figure 16F, the required shield thickness is 5.6 in. uranium (by extrapolation).

William H. Steighimon

William H. Steigelmann

Senior Research Engineer

Approved by:

George Peter Wachtell George Peter Wachtell, Manager Nuclear Systems Laboratory
Nelson R. Usoulad

Nelson R. Droulard Technical Director

Frances 1 facloson

Francis L. Jackson

Director

$-215-$ 


\section{APPENDIX A}

\section{RADIOISOTOPE DATA}

The following table presents the half-life and gamma and beta emission data, states the relationships between the various isotopes, indicates the general quality of the data, and cites the reference from which the data were obtained. In addition to the specific references cited, others were used in a general way to confirm the data selected for specific isotopes. It should be noted that for many of the isotopes, the decay scheme and radiation emission are not accurately known, and numerous discrepancies exist between the data from different sources. The numerical values presented herein are believed to be the most nearly correct. In a few cases where a large number of gamma photons are emitted per disintegration, the least significant photons (i.e., low energy or relatively small emission) have been combined with other photons to form a smaller number of energy groups. The neutron emission data are based upon the release of three neutrons per spontaneous fission.

\section{NOMENCL ATURE}

$\begin{array}{ll}E & \text { Energy } \\ E_{\max } & \text { Maximum or end-point energy } \\ \bar{E} & \text { Average energy } \\ \mathrm{N}(E) & \text { Number of photons or particles emitted with energy } \mathrm{E} \\ & \text { per disintegration } \\ \mathrm{N}^{*}(E) \quad \text { Number of photons or particles emitted with energy } E & \text { per second per watt of power level (infinite irradiation } \\ & \text { time). }\end{array}$


1. J. Stehn, Table of Radioactive Nuclides, Nucleonics 18:II, pp. 186-195 (November 1960).

2. E. der Mateosian and M. McKeown, Table of Gamma-Rays Emitted by Radioactive Nuclei, USAEC Report BN-605 (T-177), Brookhaven National Laboratory, May 1960.

3. L. Slack and K. Way, Radiations from Radioactive Atoms in Frequent Use, USAEC Report, February 1959.

4. D. Strominger, et al, Table of Isotopes, Reviews of Modern Physics, 30:2, pt. 2, 585 ( $\overline{1958})$.

5. B. Dzhelepov and L. Peker, Decay Schemes of Radioactive Nuclei, Pergamon Press, London, 1961.

6. T. Rockwell, Reactor Shielding Design Manual, USAEC Report TID 7004, U. S. Atomic Energy Commission, 1956.

\section{GENERAL REFERENCES}

J. Blomeke and M. Todd, Uranium-235 Fission-Product Production as a Function of Thermal Neutron Flux, Irradiation Time, and Decay Time, USAEC Report ORNL-2127, Oak Ridge National Laboratory, November 1958.

K. Way (Ed.), 1960 Nuclear Data Tables, Part 4, USAEC Report, National Academy of Sciences, December 1961.

H. H. Van Tuyl, Fission Product and Radiation Shielding Calculations, USAEC Report HW 69533, Hanford Atomic Products Operation, May 1961. 


\section{RADIOISOTOPE DATA}

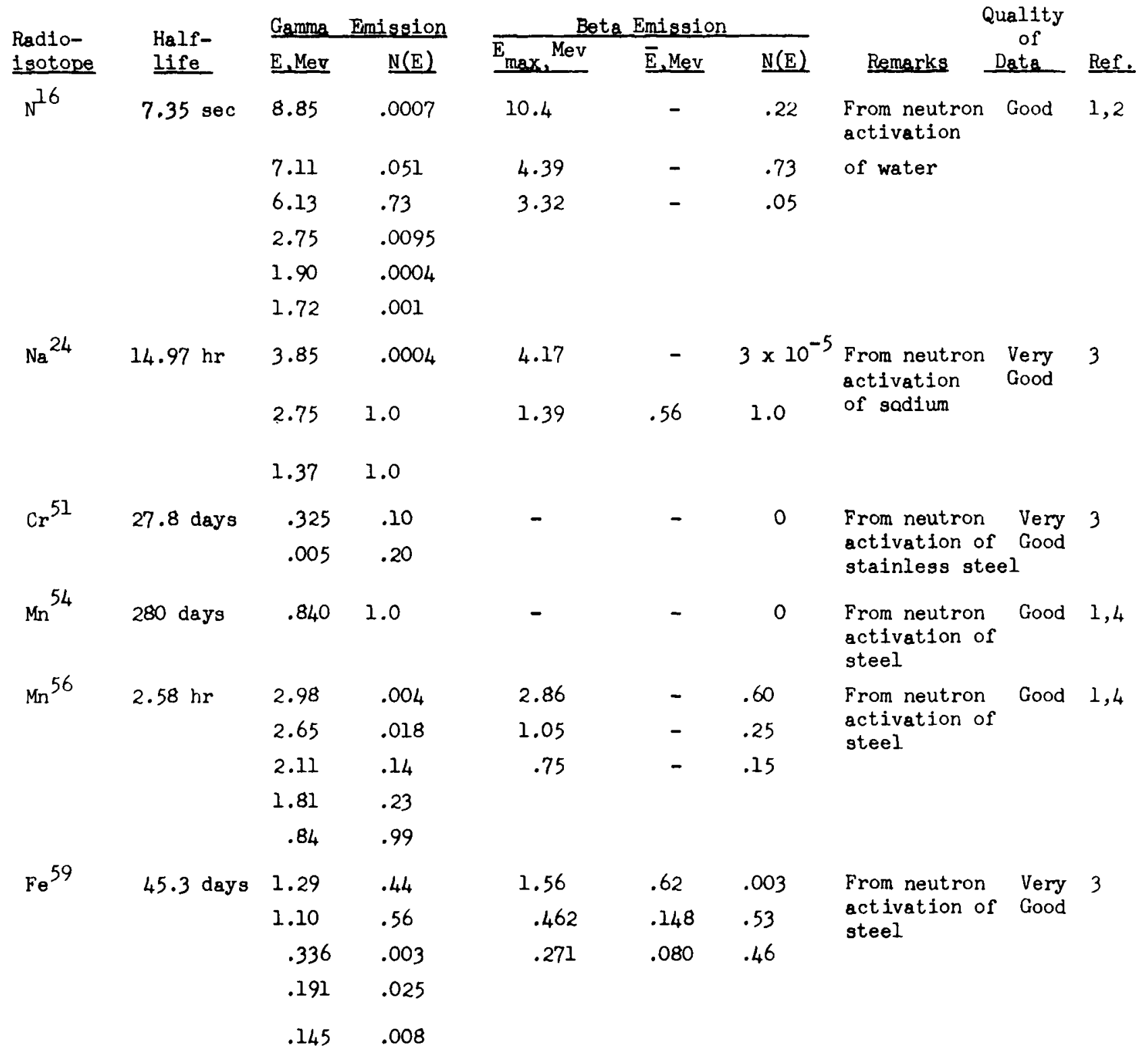




\begin{tabular}{|c|c|c|c|c|c|c|c|c|c|}
\hline \multirow{2}{*}{$\begin{array}{l}\text { Radio- } \\
\text { isotope }\end{array}$} & \multirow[b]{2}{*}{$\begin{array}{l}\text { Half- } \\
\text { Litee }\end{array}$} & \multicolumn{2}{|c|}{ Gamma Emission } & \multicolumn{3}{|c|}{ Bets Emigsion } & \multirow[b]{2}{*}{ Remarks } & \multirow{2}{*}{$\begin{array}{l}\text { Quality } \\
\text { of } \\
\text { Data } \\
\end{array}$} & \multirow[b]{2}{*}{ Ref. } \\
\hline & & E,Mev & $\mathrm{N}(\mathrm{E})$ & $\mathrm{E}_{\max } \mathrm{Mer}$ & $\bar{E}$, Mev & $\underline{N(E)}$ & & & \\
\hline \multirow[t]{3}{*}{$\mathrm{Co}^{60}$} & \multirow{3}{*}{$5.26 \mathrm{yr}$} & 2.16 & $1.2 \times 10^{-5}$ & 1.48 & - & .0001 & \multirow{3}{*}{$\begin{array}{l}\text { From neutron } \\
\text { activation }\end{array}$} & \multirow{3}{*}{$\begin{array}{l}\text { Very } \\
\text { Good }\end{array}$} & \multirow[t]{3}{*}{3} \\
\hline & & 1.33 & 1.0 & .314 & .093 & 1.0 & & & \\
\hline & & 1.17 & 1.0 & & & & & & \\
\hline \multirow[t]{8}{*}{$\mathrm{Br}^{84}$} & \multirow[t]{8}{*}{$32 \mathrm{~min}}$. & 3.93 & .125 & 4.68 & - & .40 & \multirow{8}{*}{$\begin{array}{l}\text { Fission } \\
\text { product }\end{array}$} & \multirow{8}{*}{$\begin{array}{l}\text { Fair } \\
\text { (Deduced } \\
\text { from decay } \\
\text { scheme) }\end{array}$} & \multirow[t]{8}{*}{4} \\
\hline & & 3.15 & .07 & 3.56 & - & .09 & & & \\
\hline & & 2.50 & .10 & 2.53 & - & .16 & & & \\
\hline & & 2.11 & .04 & 1.72 & - & .35 & & & \\
\hline & & 1.85 & .23 & & & & & & \\
\hline & & 1.10 & .14 & & & & & & \\
\hline & & .88 & .59 & & & & & & \\
\hline & & .60 & .145 & & & . & & & \\
\hline \multirow[t]{2}{*}{$\mathrm{Kr}^{85}$} & \multirow[t]{2}{*}{$10.4 \mathrm{yr}$} & \multirow[t]{2}{*}{.52} & \multirow[t]{2}{*}{.007} & .695 & .232 & .993 & \multirow{2}{*}{$\begin{array}{l}\text { Fission } \\
\text { product }\end{array}$} & \multirow[t]{2}{*}{ Good } & \multirow[t]{2}{*}{1,4} \\
\hline & & & & .150 & - & .007 & & & \\
\hline \multirow[t]{3}{*}{$\mathrm{Kr}^{87}$} & \multirow[t]{3}{*}{$78 \mathrm{~min}$} & 2.57 & .14 & 3.8 & - & .70 & \multirow{3}{*}{$\begin{array}{l}\text { Fission } \\
\text { product }\end{array}$} & \multirow{3}{*}{$\begin{array}{l}\text { Fair } \\
\text { (Deduced } \\
\text { from decay } \\
\text { scheme) }\end{array}$} & \multirow[t]{3}{*}{4} \\
\hline & & .85 & .16 & 3.3 & - & .05 & & & \\
\hline & & .403 & .84 & 1.27 & 1.01 & .25 & & & \\
\hline \multirow[t]{7}{*}{$\mathrm{Kr}^{88}$} & \multirow[t]{7}{*}{$2.8 \mathrm{hr}$} & 2.40 & .35 & 2.8 & - & .20 & \multirow{7}{*}{$\begin{array}{l}\text { Fission } \\
\text { product } \\
\text { (Parent of } \\
\mathrm{Rb}^{88} \text { ) }\end{array}$} & Fair & 1,4 \\
\hline & & 2.19 & .19 & .90 & - & .12 & & $\begin{array}{l}\text { (Deduced } \\
\text { from decay }\end{array}$ & \\
\hline & & 1.55 & .14 & .52 & .331 & .68 & & scheme) & \\
\hline & & .85 & .23 & & & & & & \\
\hline & & .36 & .05 & & & & & & \\
\hline & & .191 & .35 & & & & & & \\
\hline & & .166 & .07 & & & & & & \\
\hline
\end{tabular}




\begin{tabular}{|c|c|c|c|c|c|c|c|c|c|}
\hline \multirow{2}{*}{$\begin{array}{l}\text { Radio } \\
\text { isotope }\end{array}$} & \multirow{2}{*}{$\begin{array}{l}\text { Half- } \\
\text { Iife }\end{array}$} & \multicolumn{2}{|c|}{ Gamma Emission } & \multicolumn{3}{|c|}{ Beta Emission } & \multirow[b]{2}{*}{ Remerks } & \multirow{2}{*}{$\begin{array}{c}\text { Quality } \\
\text { of } \\
\text { Data } \\
\end{array}$} & \multirow[b]{2}{*}{ Ref. } \\
\hline & & E, Mev & $\underline{N(E)}$ & $\mathrm{E}_{\text {max, }} \mathrm{Mev}$ & $\overline{E_{2} \text { Mev }}$ & $\underline{N(E)}$ & & & \\
\hline \multirow[t]{8}{*}{$\mathrm{Rb}^{88}$} & \multirow{8}{*}{$\begin{array}{l}17.8 \\
\min \end{array}$} & 4.7 & .008 & 5.3 & - & .78 & \multirow{8}{*}{$\begin{array}{l}\text { Fission } \\
\text { product } \\
\text { (Dauginter } \\
\mathrm{Kr}^{88} \text { ) }\end{array}$} & \multirow{8}{*}{$\begin{array}{l}\text { Fair } \\
\text { (Deduced } \\
\text { from decay } \\
\text { scheme }\end{array}$} & \multirow[t]{8}{*}{4} \\
\hline & & 3.52 & .005 & 3.6 & - & .13 & & & \\
\hline & & 3.24 & .006 & \multirow[t]{6}{*}{2.5} & \multirow[t]{6}{*}{1.61} & \multirow[t]{6}{*}{.09} & & & \\
\hline & & 3.01 & .006 & & & & & & \\
\hline & & 2.68 & .05 & & & & & & \\
\hline & & 2.11 & .02 & & & & & & \\
\hline & & 1.85 & .45 & & & & & & \\
\hline & & .91 & .30 & & & & & & \\
\hline $\mathrm{Sr}^{90}$ & $28 \mathrm{yr}$ & 0 & 0 & .544 & .194 & 1.0 & $\begin{array}{l}\text { Fission } \\
\text { product } \\
\text { (Parent of } \\
\mathrm{Y}^{90} \text { ) }\end{array}$ & $\begin{array}{l}\text { Very } \\
\text { Good }\end{array}$ & 3 \\
\hline \multirow[t]{3}{*}{$Y^{90}$} & \multirow[t]{3}{*}{$64 \mathrm{hr}$} & \multirow[t]{3}{*}{0} & \multirow[t]{3}{*}{0} & 2.25 & .93 & 1.0 & \multirow{3}{*}{$\begin{array}{l}\text { Fission } \\
\text { product } \\
\text { (Daughter of } \\
\mathrm{Sr}^{90} \text { ) }\end{array}$} & \multirow{3}{*}{$\begin{array}{l}\text { Verg } \\
\text { Good }\end{array}$} & \multirow[t]{3}{*}{3} \\
\hline & & & & 1.75 & 1.75 & .0002 & & & \\
\hline & & & & .48 & - & .0002 & & & \\
\hline \multirow[t]{3}{*}{$2 r^{95}$} & \multirow[t]{3}{*}{65 days } & .757 & .54 & .89 & - & .03 & \multirow{3}{*}{$\begin{array}{l}\text { Fission } \\
\text { product } \\
\text { (Parent of } \\
\mathrm{Nb}^{95 \mathrm{~m}}(3 \%) \\
\text { and } \mathrm{Nb} 95 \\
(97 \%))\end{array}$} & \multirow[t]{3}{*}{ Good } & \multirow[t]{3}{*}{4} \\
\hline & & .724 & .43 & .396 & - & .43 & & & \\
\hline & & & & .364 & .127 & .54 & & & \\
\hline $\mathrm{Nb}^{95 \mathrm{~m}}$ & $90 \mathrm{hr}$ & .231 & 1.0 & - & - & 0 & $\begin{array}{l}\text { Fissior } \\
\text { product } \\
\text { (Daughter of } \\
\mathrm{Zr}^{95} \text { and } \\
\text { parent of } \\
\mathrm{Nb}^{95}(100 \%) \text { ) }\end{array}$ & Good & 1,4 \\
\hline \multirow[t]{2}{*}{$\mathrm{Nb}^{95}$} & \multirow[t]{2}{*}{35 days } & .768 & .99 & .93 & - & .01 & \multirow{2}{*}{$\begin{array}{l}\text { Fission } \\
\text { product } \\
\text { (Daughter of } \\
\mathrm{Zr}^{95} \text { and } \\
\mathrm{Nb}^{95 \mathrm{~m}} \text { ) }\end{array}$} & \multirow[t]{2}{*}{ Good } & \multirow[t]{2}{*}{1,4} \\
\hline & & .204 & .01 & .158 & - & .99 & & & \\
\hline
\end{tabular}




\begin{tabular}{|c|c|c|c|c|c|c|c|c|c|}
\hline \multirow{2}{*}{$\begin{array}{l}\text { Rad 10- } \\
\text { Isotope }\end{array}$} & \multirow{2}{*}{$\begin{array}{l}\text { Half- } \\
\text { life }\end{array}$} & \multicolumn{2}{|c|}{ Gamma Emisston } & \multicolumn{3}{|c|}{ Beta Emission } & \multirow{2}{*}{\multicolumn{2}{|c|}{$\begin{array}{c}\text { Quality } \\
\text { of } \\
\text { Data } \\
\end{array}$}} & \multirow[b]{2}{*}{ Ref. } \\
\hline & & $\mathrm{E}, \mathrm{Mev}$ & $\underline{N(E)}$ & $E_{\max ,} \overline{M e v}$ & $\overline{\bar{E}_{2} \mathrm{Mev}}$ & $\underline{\mathrm{N}(E)}$ & & & \\
\hline \multirow{4}{*}{$\mathrm{Nb}^{97}{ }^{97}-$} & $17.0 \mathrm{hr}$ & 2.20 & .01 & 1.91 & .64 & .96 & \multirow{4}{*}{$\begin{array}{l}\text { Fission } \\
\text { products } \\
\text { (Barents of } \\
\mathrm{Nb}^{97} \text { ) }\end{array}$} & \multirow[t]{4}{*}{ Fair } & \multirow[t]{4}{*}{4,5} \\
\hline & \multirow{3}{*}{$\begin{array}{l}-1.0 \\
\text { min. }\end{array}$} & 1.62 & .02 & .94 & - & .025 & & & \\
\hline & & 1.35 & .04 & .89 & - & .015 & & & \\
\hline & & .75 & .96 & & & & & & \\
\hline \multirow[t]{2}{*}{$\mathrm{Nb}^{97}$} & \multirow{2}{*}{$\begin{array}{l}72 \\
\text { min }\end{array}$} & 1.02 & .01 & 1.27 & - & .99 & \multirow{2}{*}{$\begin{array}{l}\text { Fission } \\
\text { product } \\
\text { (Deughter of } \\
\mathrm{Zr}^{97}-\mathrm{Nb}^{97 \mathrm{~m}} \text { ) }\end{array}$} & \multirow[t]{2}{*}{ Good } & \multirow[t]{2}{*}{$1,4,5$} \\
\hline & & .665 & .99 & .92 & - & .01 & & & \\
\hline \multirow{6}{*}{$\begin{array}{l}\mathrm{Ru}^{103}- \\
\mathrm{Rh}^{103 \mathrm{~m}}\end{array}$} & \multirow{6}{*}{$\begin{array}{l}40 \\
\text { days } \\
-57 \\
\text { min }\end{array}$} & .61 & .065 & .715 & - & .03 & \multirow{6}{*}{$\begin{array}{l}\text { Fission } \\
\text { products }\end{array}$} & \multirow[t]{6}{*}{ Good } & \multirow[t]{6}{*}{4,5} \\
\hline & & .56 & .005 & .221 & .08 & .90 & & & \\
\hline & & .495 & .90 & .110 & - & .07 & & & \\
\hline & & .44 & .005 & & & & & & \\
\hline & & .055 & .005 & & & & & & \\
\hline & & .040 & .975 & & & & & & \\
\hline \multirow[t]{7}{*}{$\mathrm{Sb}^{124}$} & \multirow{7}{*}{$\begin{array}{l}60 \\
\text { days }\end{array}$} & 2.09 & .067 & 2.39 & - & .22 & \multirow{7}{*}{$\begin{array}{l}\text { Fission } \\
\text { product }\end{array}$} & \multirow{7}{*}{$\begin{array}{l}\text { Fair } \\
\text { (Deduced } \\
\text { from dec } \\
\text { scheme) }\end{array}$} & \multirow{7}{*}{$\begin{array}{l}1,4,5 \\
\text { cay }\end{array}$} \\
\hline & & 1.69 & .48 & 1.68 & - & .06 & & & \\
\hline & & 1.36 & .067 & 1.04 & - & .04 & & & \\
\hline & & .98 & .043 & .63 & - & .56 & & & \\
\hline & & .716 & .14 & .28 & - & .12 & & & \\
\hline & & .646 & .06 & & & & & & \\
\hline & & .603 & .98 & & & & & & \\
\hline$I^{125}$ & $\begin{array}{l}60 \\
\text { days }\end{array}$ & .0355 & 1.0 & - & - & 0 & $\begin{array}{l}\text { Fission } \\
\text { product }\end{array}$ & $\begin{array}{l}\text { Very } \\
\text { Good }\end{array}$ & $1,4,5$ \\
\hline \multirow[t]{7}{*}{$\mathrm{I}^{131}$} & \multirow{7}{*}{$\begin{array}{l}8.07 \\
\text { days }\end{array}$} & .724 & .03 & .812 & .272 & .007 & \multirow{7}{*}{$\begin{array}{l}\text { Fission } \\
\text { product } \\
\text { (Parent of } \\
\mathrm{Xe}^{\operatorname{l3lm}(0.7 \%))}\end{array}$} & \multirow{7}{*}{$\begin{array}{l}\text { Very } \\
\text { Good }\end{array}$} & 3 \\
\hline & & .638 & .09 & .608 & .193 & .872 & & & \\
\hline & & .365 & .79 & .335 & .098 & .093 & & & \\
\hline & & .284 & .06 & .250 & .071 & .028 & & & \\
\hline & & .080 & .02 & & & & & & \\
\hline & & .030 & .05 & & & & & & \\
\hline & & .005 & .006 & & & & & & \\
\hline
\end{tabular}




\begin{tabular}{|c|c|c|c|c|c|c|c|c|c|}
\hline \multirow{2}{*}{$\begin{array}{l}\text { Radio- } \\
\text { Isotope }\end{array}$} & \multirow{2}{*}{$\begin{array}{l}\text { Half- } \\
\text { life }\end{array}$} & \multicolumn{2}{|c|}{ Ganms Emission } & \multicolumn{3}{|c|}{ Beta Emigsion } & \multirow[b]{2}{*}{ Remarkg } & \multirow{2}{*}{$\begin{array}{c}\text { Quality } \\
\text { of } \\
\text { Dats } \\
\end{array}$} & \multirow[b]{2}{*}{ Ref. } \\
\hline & & E,Mev & $\underline{N(E)}$ & $\bar{E}_{\text {mex. }}{ }^{\text {Mov }}$ & $\underline{\bar{E}, \text { Mev }}$ & $\underline{N(E)}$ & & & \\
\hline $\mathrm{Xe}^{13 \mathrm{~lm}}$ & $\begin{array}{l}12 \\
\text { days }\end{array}$ & .164 & 1.0 & - & - & 0 & $\begin{array}{l}\text { Fission } \\
\text { product } \\
\text { (Daughter of } \\
\mathrm{I}^{131} \text { ) }\end{array}$ & $\begin{array}{l}\text { Very } \\
\text { Good }\end{array}$ & 3 \\
\hline \multirow[t]{3}{*}{$I^{133}$} & \multirow[t]{3}{*}{$21 \mathrm{hr}$} & 1.4 & .01 & 1.6 & - & .01 & \multirow{3}{*}{$\begin{array}{l}\text { Fission } \\
\text { product } \\
\text { (Parent of } \\
\mathrm{Xe}^{133 \mathrm{~m}}(1 \%) \& \\
\mathrm{Xe}^{133}(99 \%) \text { ) }\end{array}$} & \multirow{3}{*}{$\begin{array}{l}\text { Very } \\
\text { Good }\end{array}$} & \multirow[t]{3}{*}{5} \\
\hline & & .85 & .05 & 1.3 & - & .93 & & & \\
\hline & & .53 & .99 & .4 & - & .06 & & & \\
\hline$X e^{133 m}$ & $\begin{array}{l}2.3 \\
\text { days }\end{array}$ & .233 & 1.0 & - & - & 0 & $\begin{array}{l}\text { Fission } \\
\text { product } \\
\text { (Daughter of } \\
\mathrm{I}^{133} \text { and } \\
\text { parent of } \\
\mathrm{Xe}^{133}(100 \%) \text { ) }\end{array}$ & $\begin{array}{l}\text { Very } \\
\text { Good }\end{array}$ & $1,4,5$ \\
\hline $\mathrm{Xe}^{133}$ & $\begin{array}{l}5.27 \\
\text { days }\end{array}$ & .081 & 1.0 & .35 & .115 & 1.00 & $\begin{array}{l}\text { Fission } \\
\text { product } \\
\text { (Daughter of } \\
\mathrm{I}^{133} \text { and } \\
\mathrm{Xe}^{133 \mathrm{~m}} \text { ) }\end{array}$ & Good & 4,5 \\
\hline \multirow[t]{7}{*}{$\mathrm{Cs}^{134}$} & \multirow[t]{7}{*}{$2.1 \mathrm{yr}$} & 1.37 & .04 & .66 & - & .75 & \multirow{7}{*}{$\begin{array}{l}\text { Fission } \\
\text { product }\end{array}$} & \multirow{7}{*}{$\begin{array}{l}\text { Fair } \\
\text { (Conflict } \\
\text { between } \\
\text { sources; } \\
\text { data } \\
\text { deduced } \\
\text { from de zay } \\
\text { scheme) }\end{array}$} & \multirow[t]{7}{*}{4,5} \\
\hline & & 1.10 & .08 & .09 & - & .25 & & & \\
\hline & & .798 & 1.12 & & & & & & \\
\hline & & .662 & .02 & & & & & & \\
\hline & & .606 & .97 & & & & & & \\
\hline & & .568 & .34 & & & & & & \\
\hline & & .204 & .08 & & & & & & \\
\hline
\end{tabular}




\begin{tabular}{|c|c|c|c|c|c|c|c|c|c|}
\hline \multirow{2}{*}{$\begin{array}{l}\text { Radio- } \\
\text { 1gotope }\end{array}$} & \multirow{2}{*}{$\begin{array}{l}\text { Half- } \\
\text { life }\end{array}$} & \multicolumn{2}{|c|}{ Gamma Emission } & \multicolumn{3}{|c|}{ Beta Emission } & \multirow{2}{*}{\multicolumn{2}{|c|}{$\begin{array}{c}\text { Quality } \\
\text { of } \\
\text { Data } \\
\end{array}$}} & \multirow[b]{2}{*}{$\underline{\text { Ref. }}$. } \\
\hline & & $\underline{E}, \mathrm{Mev}$ & $\underline{N(E)}$ & $\mathrm{E}_{\text {max }} \mathrm{Mev}$ & $\underline{\bar{E}}, \mathrm{Mev}$ & $\underline{N(E)}$ & & & \\
\hline \multirow{8}{*}{$\begin{array}{l}I^{135}- \\
X_{e}{ }^{135 m}\end{array}$} & $6.7 \mathrm{hr}$ & 1.80 & .11 & 1.4 & - & .25 & \multirow{8}{*}{$\begin{array}{l}\text { Fission } \\
\text { product } \\
\text { (Parent of } \\
\mathrm{Xe}^{135} \text { ) }\end{array}$} & \multirow[t]{8}{*}{ Good } & \multirow[t]{8}{*}{1,4} \\
\hline & \multirow[t]{7}{*}{$-15.3 \mathrm{~min}$} & 1.72 & .19 & 1.0 & - & .40 & & & \\
\hline & & 1.46 & .12 & .5 & .308 & .35 & & & \\
\hline & & 1.28 & .34 & & & & & & \\
\hline & & 1.14 & .37 & & & & & & \\
\hline & & 1.04 & .09 & & & & & & \\
\hline & & .86 & .11 & & & & & & \\
\hline & & .53 & .36 & & & & & & \\
\hline \multirow[t]{3}{*}{$\mathrm{Xe}^{135}$} & \multirow[t]{3}{*}{$9.2 \mathrm{hr}$} & .61 & .03 & .91 & - & .97 & \multirow{3}{*}{\multicolumn{2}{|c|}{$\begin{array}{l}\text { Fission Very } \\
\text { product Good } \\
\text { (Daughter of } \\
\mathrm{I}^{135}-\mathrm{Xe} \mathrm{e}^{135 \mathrm{~m}} \text { ) }\end{array}$}} & \multirow[t]{3}{*}{$1,4,5$} \\
\hline & & .36 & .001 & .55 & .302 & .03 & & & \\
\hline & & .25 & .97 & & & & & & \\
\hline \multirow{2}{*}{$\mathrm{Cs}^{137}-$} & \multirow{2}{*}{$\begin{array}{l}30 \mathrm{yr}- \\
2.6 \mathrm{~min}\end{array}$} & \multirow[t]{2}{*}{.662} & \multirow[t]{2}{*}{.92} & 1.17 & - & .08 & \multirow{2}{*}{$\begin{array}{l}\text { Fission } \\
\text { product }\end{array}$} & \multirow{2}{*}{$\begin{array}{l}\text { Very } \\
\text { Good }\end{array}$} & \multirow[t]{2}{*}{$1,4,5$} \\
\hline & & & & .52 & .192 & .92 & & & \\
\hline \multirow[t]{3}{*}{$\mathrm{Ba}^{140}$} & \multirow{3}{*}{$\begin{array}{l}12.8 \\
\text { days }\end{array}$} & .54 & .25 & 1.02 & - & .60 & \multirow{3}{*}{$\begin{array}{c}\text { Fission } \\
\text { product } \\
\left(\mathrm{P}_{\text {arent of }}\right. \\
\mathrm{L}_{\mathrm{a}} 140 \text { ) }\end{array}$} & \multirow{3}{*}{$\begin{array}{l}\text { Fair } \\
\text { (Deduced } \\
\text { from } \\
\text { decay } \\
\text { scheme) }\end{array}$} & \multirow[t]{3}{*}{$1,4,5$} \\
\hline & & .40 & .15 & .48 & .268 & .40 & & & \\
\hline & & .03 & .75 & & & & & & \\
\hline \multirow[t]{6}{*}{$\mathrm{L}_{\mathrm{Q}}{ }^{140}$} & \multirow[t]{6}{*}{$40.2 \mathrm{hr}$} & 2.6 & .05 & 2.20 & - & .08 & \multirow{6}{*}{$\begin{array}{l}\text { Fission } \\
\text { product } \\
\text { ( } \text { (nughter of }^{140} \text { ) } \\
\text { Ba }^{140} \text { ) }\end{array}$} & \multirow{6}{*}{$\begin{array}{l}\text { Fair } \\
\text { (Very } \\
\text { complex; } \\
\text { data ded } \\
\text { from dec } \\
\text { scheme) }\end{array}$} & \multirow[t]{6}{*}{1,4} \\
\hline & & 1.62 & .88 & 1.62 & - & .14 & & & \\
\hline & & .875 & .40 & 1.36 & .50 & .30 & & & \\
\hline & & .490 & .44 & 1.15 & - & .20 & & & \\
\hline & & .438 & .05 & .86 & - & .12 & & & \\
\hline & & .328 & .35 & .42 & - & .16 & & & \\
\hline
\end{tabular}




\begin{tabular}{|c|c|c|c|c|c|c|c|c|c|}
\hline \multirow{2}{*}{$\begin{array}{l}\text { Radio- } \\
\text { Isotope }\end{array}$} & \multirow{2}{*}{$\begin{array}{l}\text { Half- } \\
\text { life }\end{array}$} & \multicolumn{2}{|c|}{ Gemma Emisgion } & \multicolumn{3}{|c|}{ Bete Emisgion } & \multirow{2}{*}{\multicolumn{2}{|c|}{$\begin{array}{c}\text { Quelity } \\
\text { of } \\
\text { Dote } \\
\end{array}$}} & \multirow[b]{2}{*}{ Ref. } \\
\hline & & E.Mev & $\underline{N(E)}$ & $E_{\text {max. }} \mathrm{Mev}$ & $\bar{E}$, Mev & $\underline{N(E)}$ & & & \\
\hline \multirow{6}{*}{$\begin{array}{l}\mathrm{Ce}^{144} \text { - } \\
\mathrm{Pr}^{144}\end{array}$} & \multirow{6}{*}{$\begin{array}{l}285 \\
\text { days- } \\
17.3 \\
\text { min }\end{array}$} & 2.19 & .01 & 3.15 & - & .95 & \multirow{6}{*}{$\begin{array}{l}\text { Fission } \\
\text { product }\end{array}$} & \multirow[t]{6}{*}{ Fair } & \multirow[t]{6}{*}{5} \\
\hline & & 1.48 & .01 & 2.45 & - & .03 & & & \\
\hline & & .695 & .04 & .90 & - & .02 & & & \\
\hline & & .134 & .17 & .309 & - & .76 & & & \\
\hline & & .081 & .07 & .175 & - & .24 & & & \\
\hline & & .054 & .07 & & & & & & \\
\hline $\mathrm{Pm}^{147}$ & $\begin{array}{r}2.6 \\
\mathrm{yr}\end{array}$ & .121 & .0001 & .223 & .074 & 1.00 & $\begin{array}{l}\text { Fission } \\
\text { product }\end{array}$ & Good & $1,4,5$ \\
\hline \multirow[t]{2}{*}{$\mathrm{Tm}^{170}$} & \multirow{2}{*}{$\begin{array}{l}129 \\
\text { days }\end{array}$} & \multirow[t]{2}{*}{.084} & \multirow[t]{2}{*}{.22} & .96 & - & .78 & \multirow{2}{*}{$\begin{array}{l}\text { From neutron } \\
\text { activation }\end{array}$} & \multirow[t]{2}{*}{ Good } & \multirow[t]{2}{*}{1,4} \\
\hline & & & & .88 & - & .22 & & & \\
\hline \multirow[t]{8}{*}{$\mathrm{Ir}^{192}$} & \multirow{8}{*}{$\begin{array}{l}74 \\
\text { days }\end{array}$} & .885 & .02 & .67 & - & .48 & \multirow{8}{*}{$\begin{array}{l}\text { From neutron } \\
\text { activation of } \\
\text { iridium }\end{array}$} & \multirow{8}{*}{$\begin{array}{l}\text { Fair } \\
\text { (Deduced } \\
\text { from } \\
\text { decay } \\
\text { scheme) }\end{array}$} & \multirow[t]{8}{*}{4,5} \\
\hline & & .61 & .19 & .54 & - & .41 & & & \\
\hline & & .59 & .04 & .26 & - & .07 & & & \\
\hline & & .468 & .54 & & & & & & \\
\hline & & .317 & .88 & & & & & & \\
\hline & & .308 & .30 & & & & & & \\
\hline & & .295 & .29 & & & & & & \\
\hline & & .15 & .10 & & & & & & \\
\hline \multirow[t]{5}{*}{$\mathrm{Au}^{198}$} & \multirow{5}{*}{$\begin{array}{l}2.7 \\
\text { days }\end{array}$} & 1.089 & .0016 & 1.37 & .475 & .00025 & \multirow{5}{*}{$\begin{array}{l}\text { From neutron } \\
\text { activation of } \\
\text { gold }\end{array}$} & \multirow{5}{*}{$\begin{array}{l}\text { Very } \\
\text { Good }\end{array}$} & \multirow[t]{5}{*}{3} \\
\hline & & .676 & .0082 & .959 & .314 & .99 & & & \\
\hline & & .412 & .95 & .282 & .079 & .0098 & & & \\
\hline & & .07 & .027 & & & & & & \\
\hline & & .009 & .013 & & & & & & \\
\hline
\end{tabular}




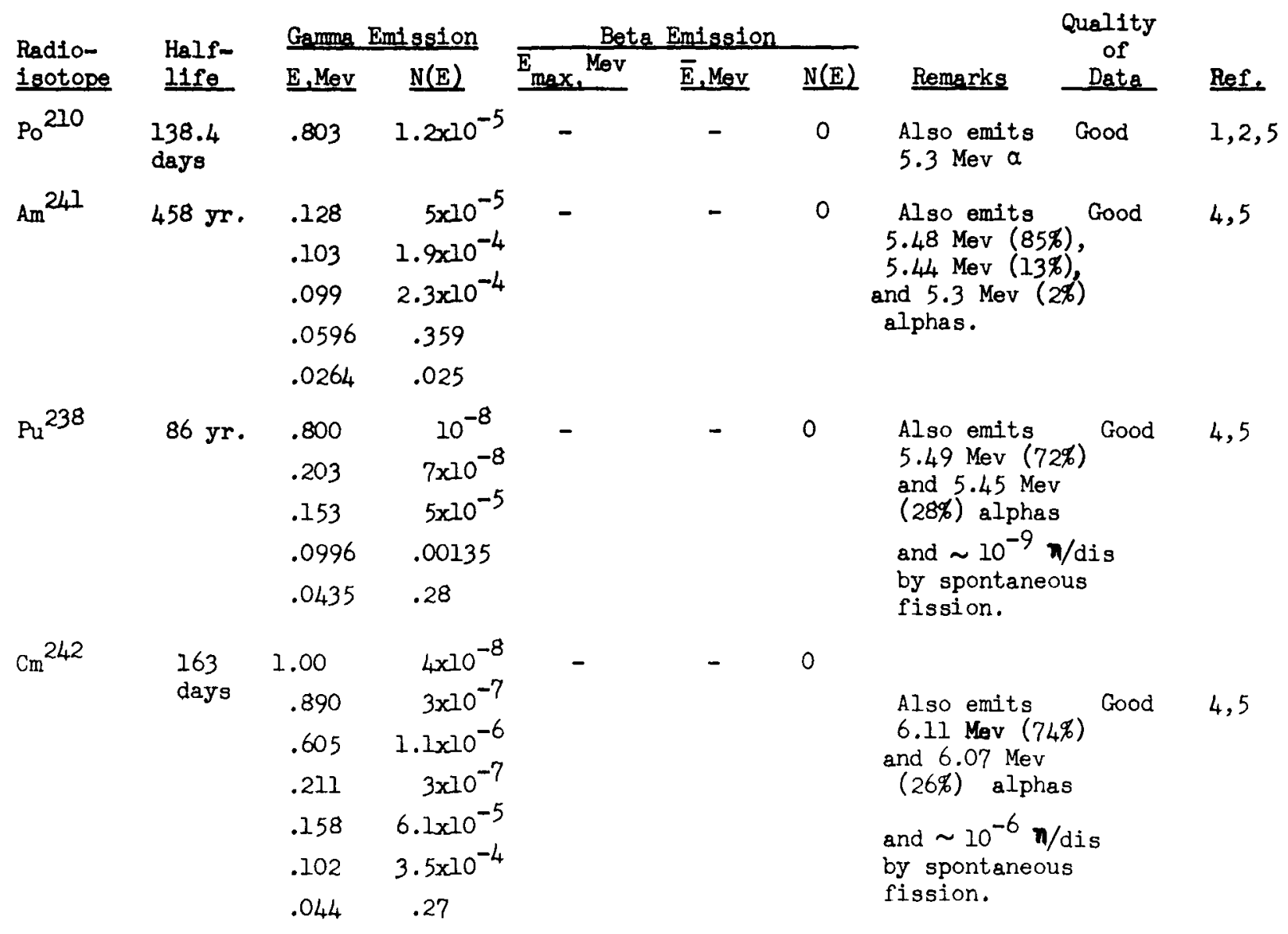




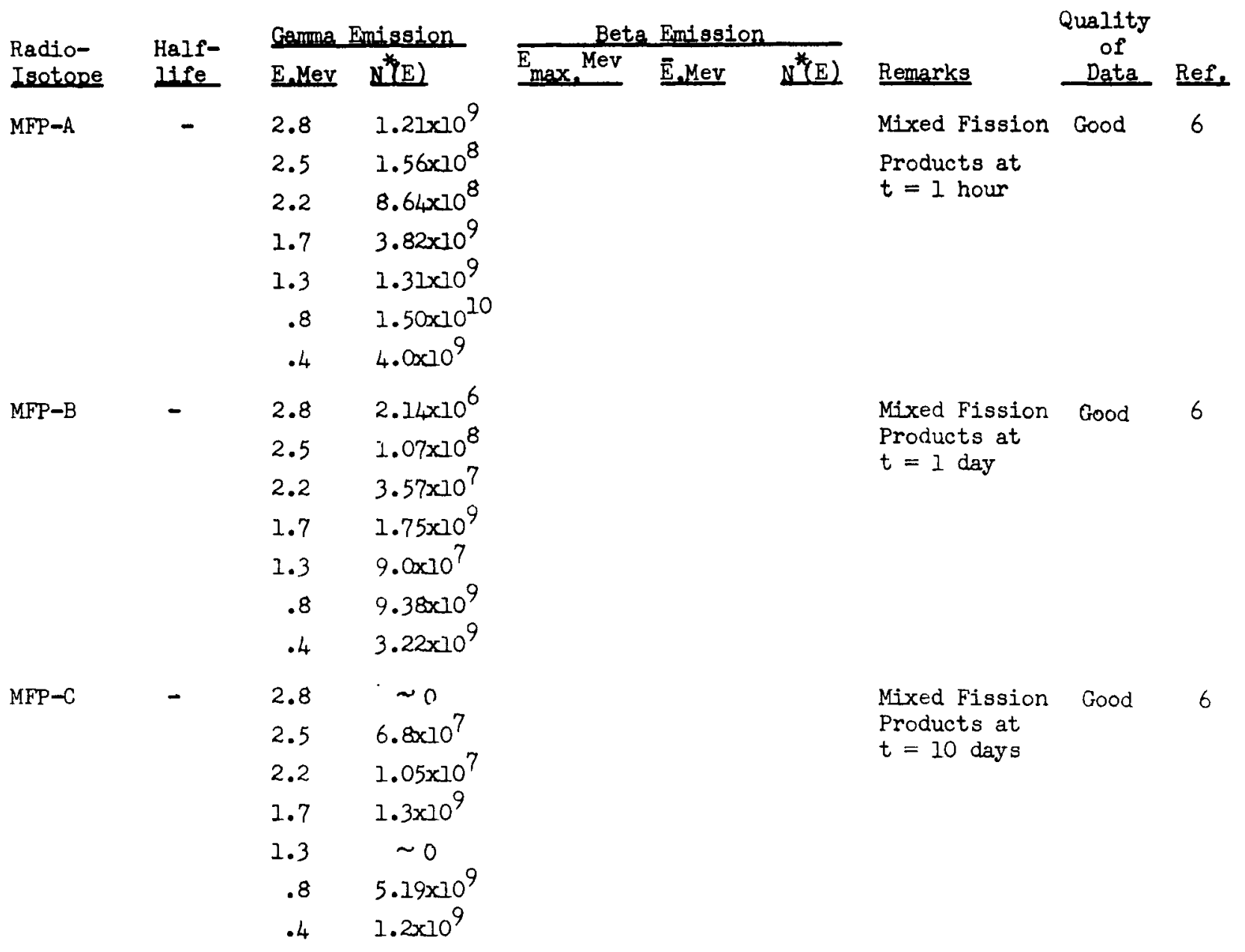




\begin{tabular}{|c|c|c|c|c|c|c|c|c|c|}
\hline \multirow[b]{2}{*}{$\begin{array}{l}\text { Radio- } \\
\text { 1 gotope }\end{array}$} & \multirow[b]{2}{*}{$\begin{array}{l}\text { Half- } \\
\text { life }\end{array}$} & \multicolumn{2}{|c|}{ Gamma Emtssion } & \multicolumn{3}{|c|}{ Beta Emisgion } & \multicolumn{3}{|c|}{ Quality } \\
\hline & & E,Mev & $\underline{\mathrm{N}^{*}(E)}$ & $E_{\max } M e v$ & $\underline{\bar{E}, \mathrm{MeV}}$ & $N^{*}(B)$ & Remarks & $\begin{array}{c}\text { of } \\
\text { Data }\end{array}$ & Ref. \\
\hline \multirow[t]{7}{*}{ MFP-D } & - & 2.8 & $\sim 0$ & & & & \multirow{7}{*}{$\begin{array}{l}\text { Mixed fission } \\
\text { products at } \\
t=1 \text { month }\end{array}$} & \multirow[t]{7}{*}{ Good } & \multirow[t]{7}{*}{6} \\
\hline & & 2.5 & $2.52 \times 10^{7}$ & & & & & & \\
\hline & & 2.2 & $7.36 \times 10^{6}$ & & & & & & \\
\hline & & 1.7 & $4.03 \times 10^{8}$ & & & & & & \\
\hline & & 1.3 & $\sim 0$ & & & & & & \\
\hline & & .8 & $3.38 \times 10^{9}$ & & & & & & \\
\hline & & .4 & $4.85 \times 10^{8}$ & & & & & & \\
\hline \multirow[t]{7}{*}{ MFP-E } & - & 2.8 & $\sim 0$ & & & & \multirow{7}{*}{$\begin{array}{l}\text { Mixed fission } \\
\text { products at } \\
t=6 \text { months }\end{array}$} & \multirow[t]{7}{*}{ Good } & \multirow[t]{7}{*}{6} \\
\hline & & 2.5 & $5.6 \times 10^{5}$ & & & & & & \\
\hline & & 2.2 & $4.91 \times 10^{6}$ & & & & & & \\
\hline & & 1.7 & $2.0 \times 10^{6}$ & & & & & & \\
\hline & & 1.3 & $\sim 0$ & & & & & & \\
\hline & & .8 & $1.28 \times 10^{9}$ & & & & & & \\
\hline & & .4 & $1.12 \times 10^{7}$ & & & & & & \\
\hline
\end{tabular}




\section{APPENDIX B}

FLUX: DOSE-RATE CONVERSION FACTOR AND SHIELDING PROPERTIES OF MATERIALS

The number-flux: dose-rate conversion factor for gamma rays and for neutrons were calculated from the data in Tables 2-1 and 2-6 of Goldstein ${ }^{1}$, and are presented here in Figure B-l.

The densities of the various shielding materials and the concrete composition used in the calculations for the curves in this manual are tabulated in Table B-l. The gamma-ray linear attenuation coefficients for the five materials appear as a function of energy in Figure B-2. These data were mainly also taken from Goldstein, but Walker and Grotenhuis ${ }^{2}$ was used to supply the data for the concrete. The data shown here for steel are those for iron in Ref. 1; there being no difference between the two insofar as gamma radiation shielding is concerned.

Gamma-ray dose buildup factors for the shielding materials considered in this manual appear in Figures B-3 through B-7. These five sets of curves are all for the case of a "point source" of radiation in an infinite shielding medium. The symbol $\mathrm{b}$ represents the shielding thickness expressed in attenuation lengths, $b=\mu t$, where $\mu$ is the linear attenuation coefficient (from Fig. B-2) and $t$ is the shield thickness. Data for concrete were again obtained from Ref. 2, while for the other materials Ref. 1 was again the source.

\section{REFERENCES}

1. H. Goldstein, Fundamental Aspects of Reactor Shielding, Addison-Wesley Publishing Co., Inc., Reading, Mass., 1959.

2. R. Walker and M. Grotenhuis, A Summary of Shielding Constants for Concrete, USAEC Report ANL-64 43, Argonne National Laboratory, November 1961. 
TABLE B-1: Shielding Materials Data

Densities:

\begin{tabular}{lcc} 
Material & \multicolumn{2}{c}{ Density } \\
Water & $\frac{1 \mathrm{~b} / \mathrm{ft}^{\frac{3}{3}}}{62.4}$ & $\frac{\mathrm{g} / \mathrm{cm}^{3}}{1.0}$ \\
Ordinary & & \\
$\quad$ Concrete & 144 & 2.3 \\
Steel & 490 & 7.85 \\
Lead & 708 & 11.35 \\
Uranium & 1170 & 18.75
\end{tabular}

Composition of Ordinary Concrete ${ }^{2}$ :

\begin{tabular}{cc} 
Element & Weight Fraction \\
\cline { 1 - 2 } $\mathrm{H}$ & 0.010 \\
$\mathrm{C}$ & 0.0010 \\
$\mathrm{O}$ & 0.530 \\
$\mathrm{Na}$ & 0.0160 \\
$\mathrm{Mg}$ & 0.0022 \\
$\mathrm{Al}$ & 0.0339 \\
$\mathrm{Si}$ & 0.337 \\
$\mathrm{~K}$ & 0.0130 \\
$\mathrm{Ca}$ & 0.0435 \\
$\mathrm{Fe}$ & 0.0139
\end{tabular}




\section{- OET -}

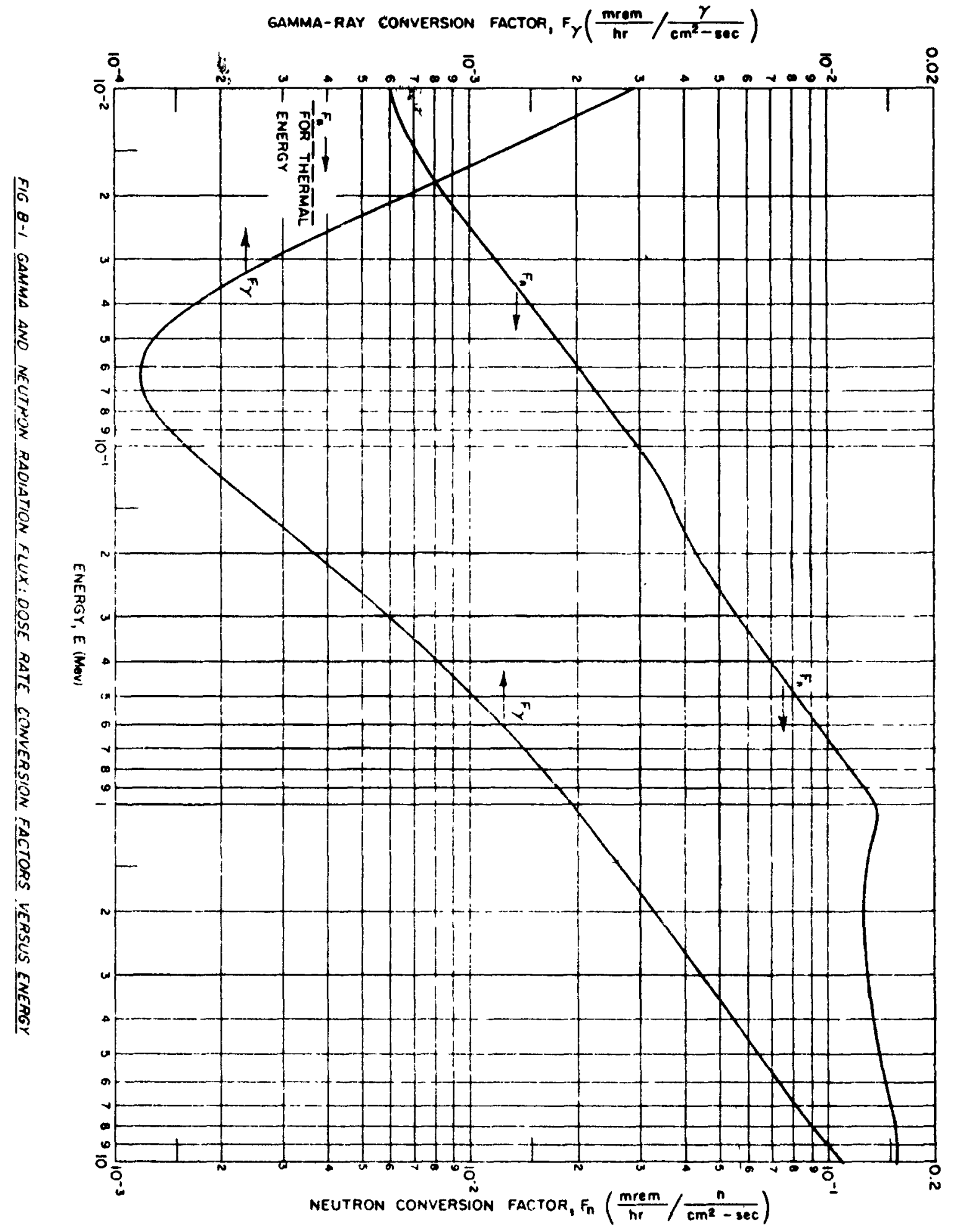




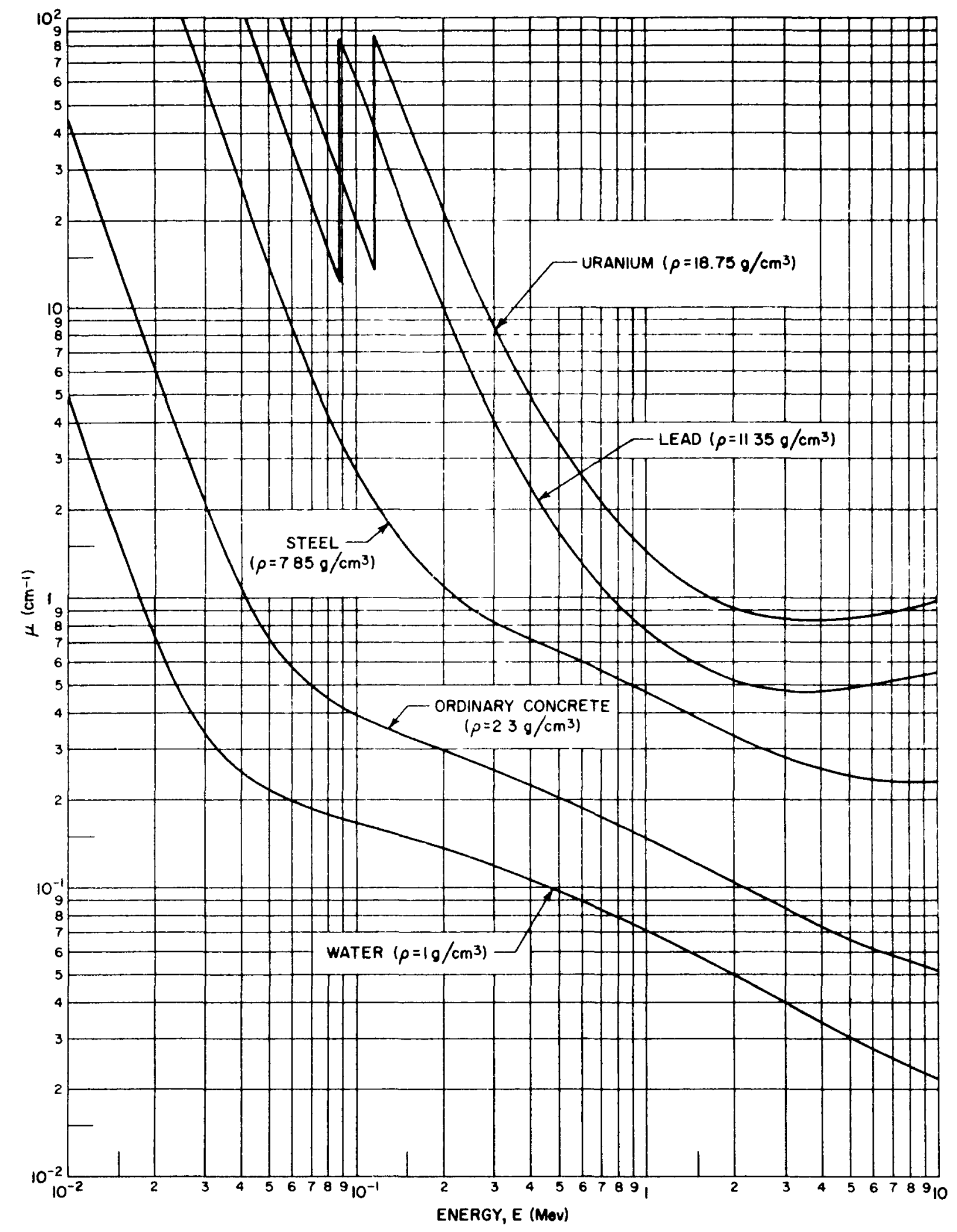

FIG. B-2 LINEAR ATTENUATION COEFFICIENT VERSUS ENERGY 


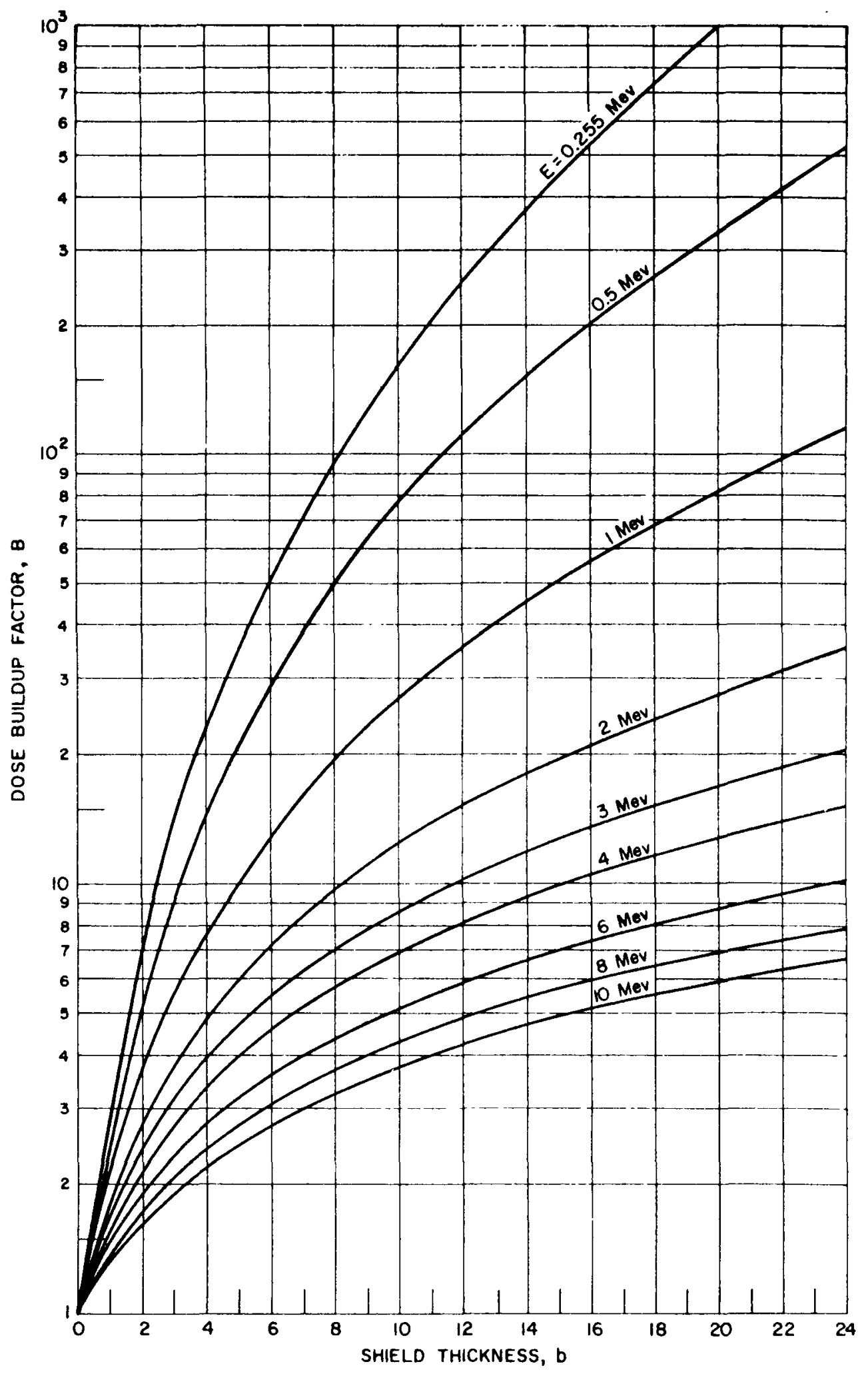

FIG. B-3. DOSE BUILDUP FACTOR FOR WATER 


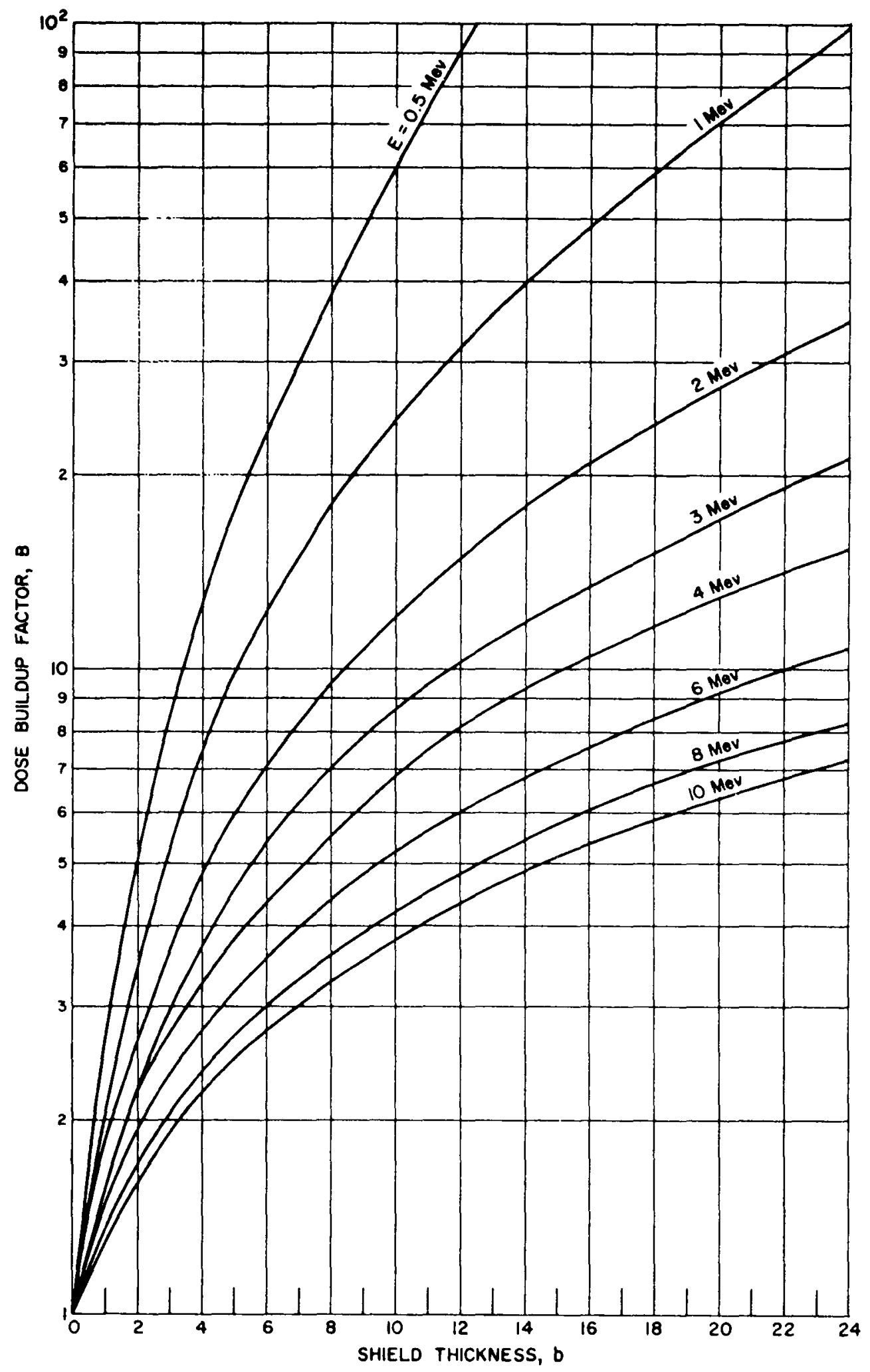

FIG. B-4. DOSE BUILDUP FACTOR FOR OROINARY CONCRETE 


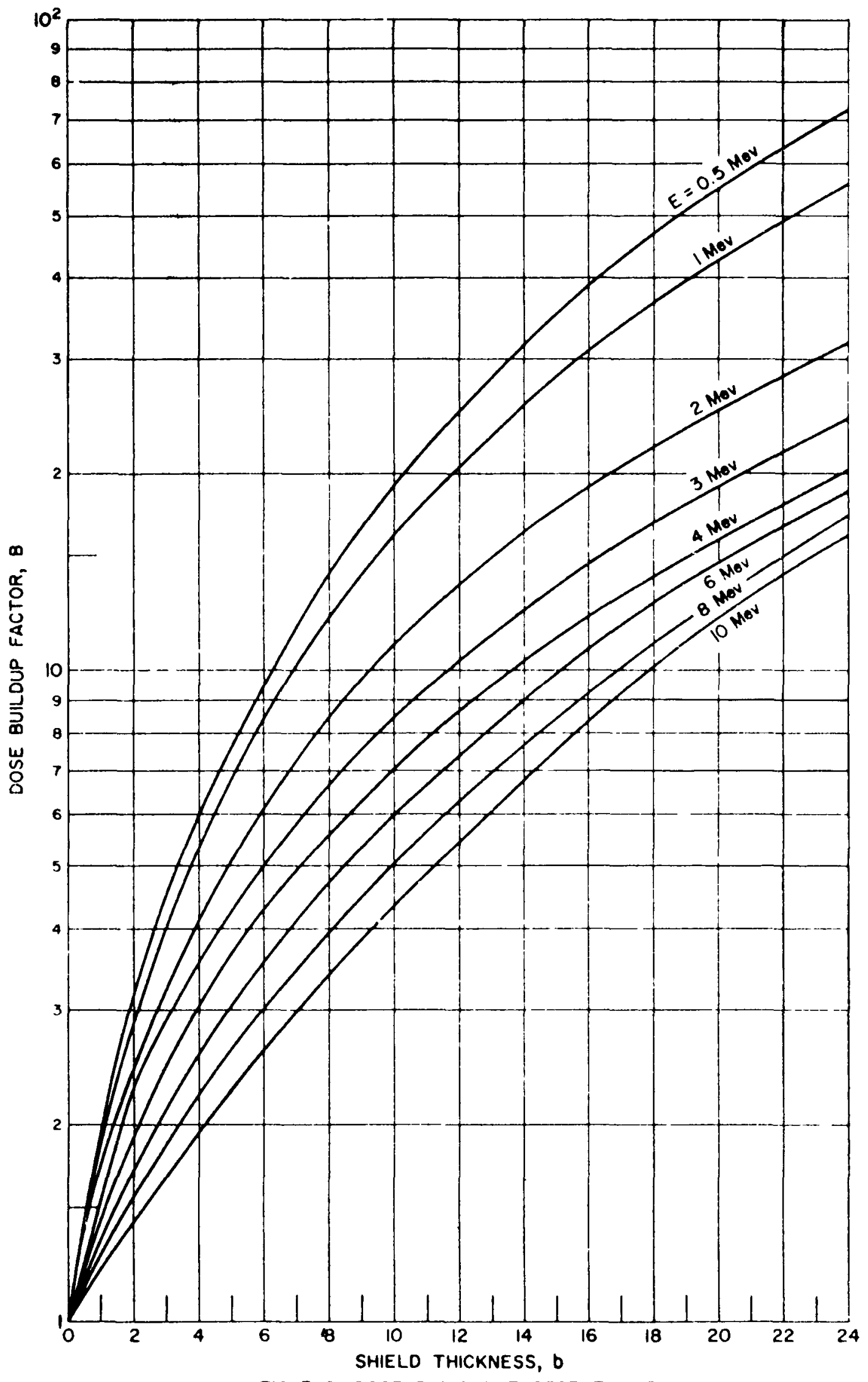

FIG B-5. DOSE BUILDUP FACTOR FOR IRON 


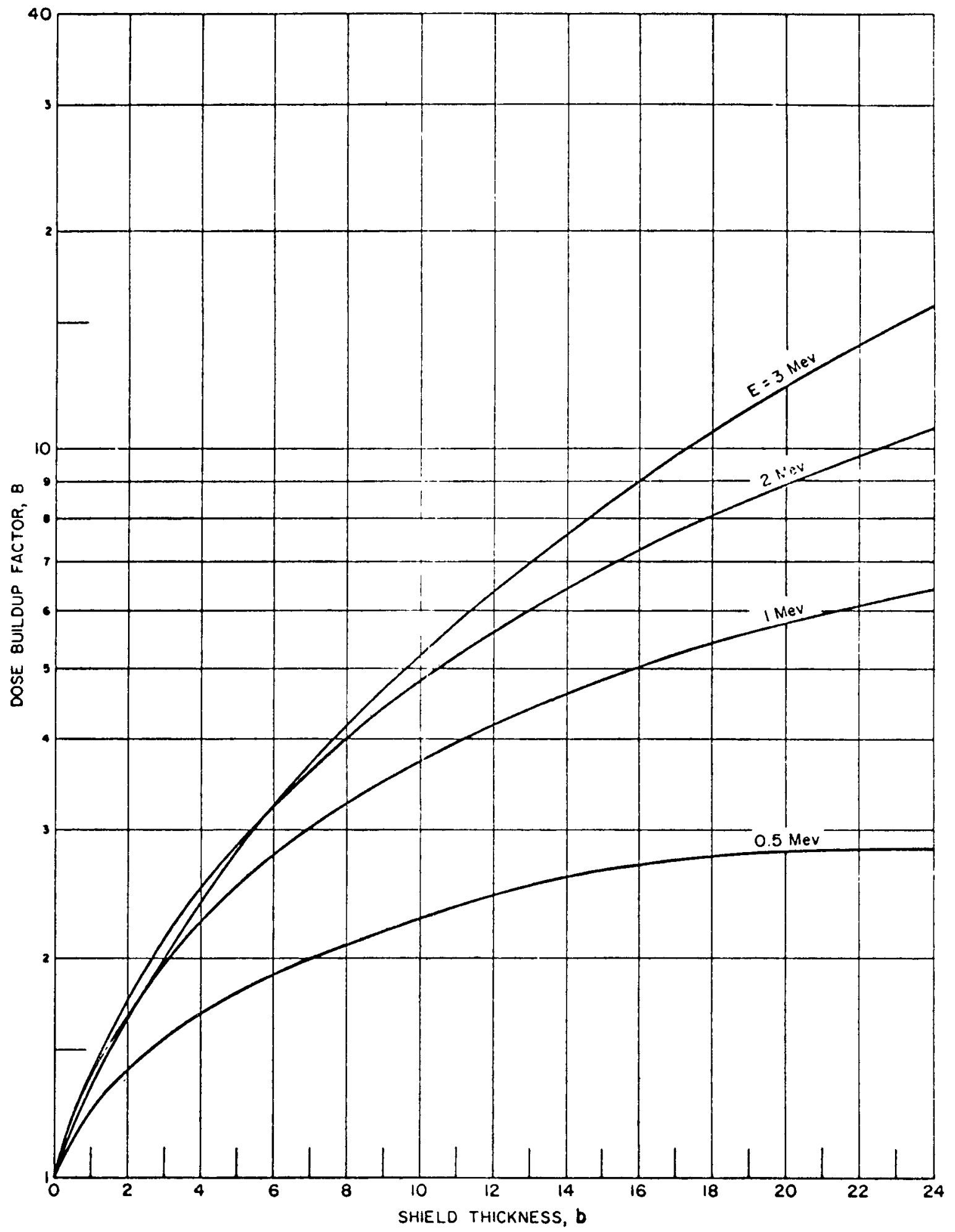

FIG. B-6a. DOSE BUILOUP FACTOR FOR LEAD 


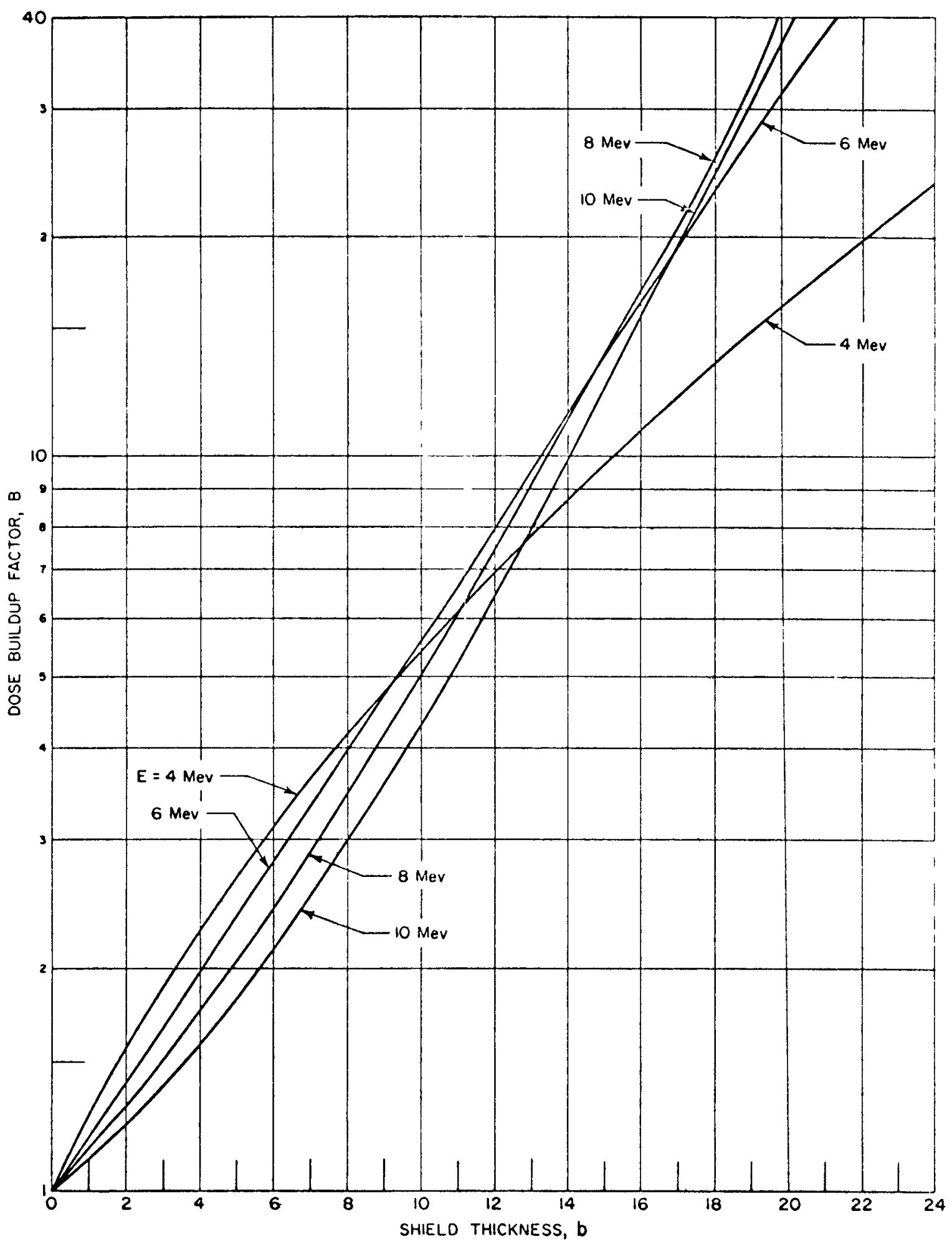

FIG B-6b. DOSE BUILOUP FACTOR FOR LEAD 


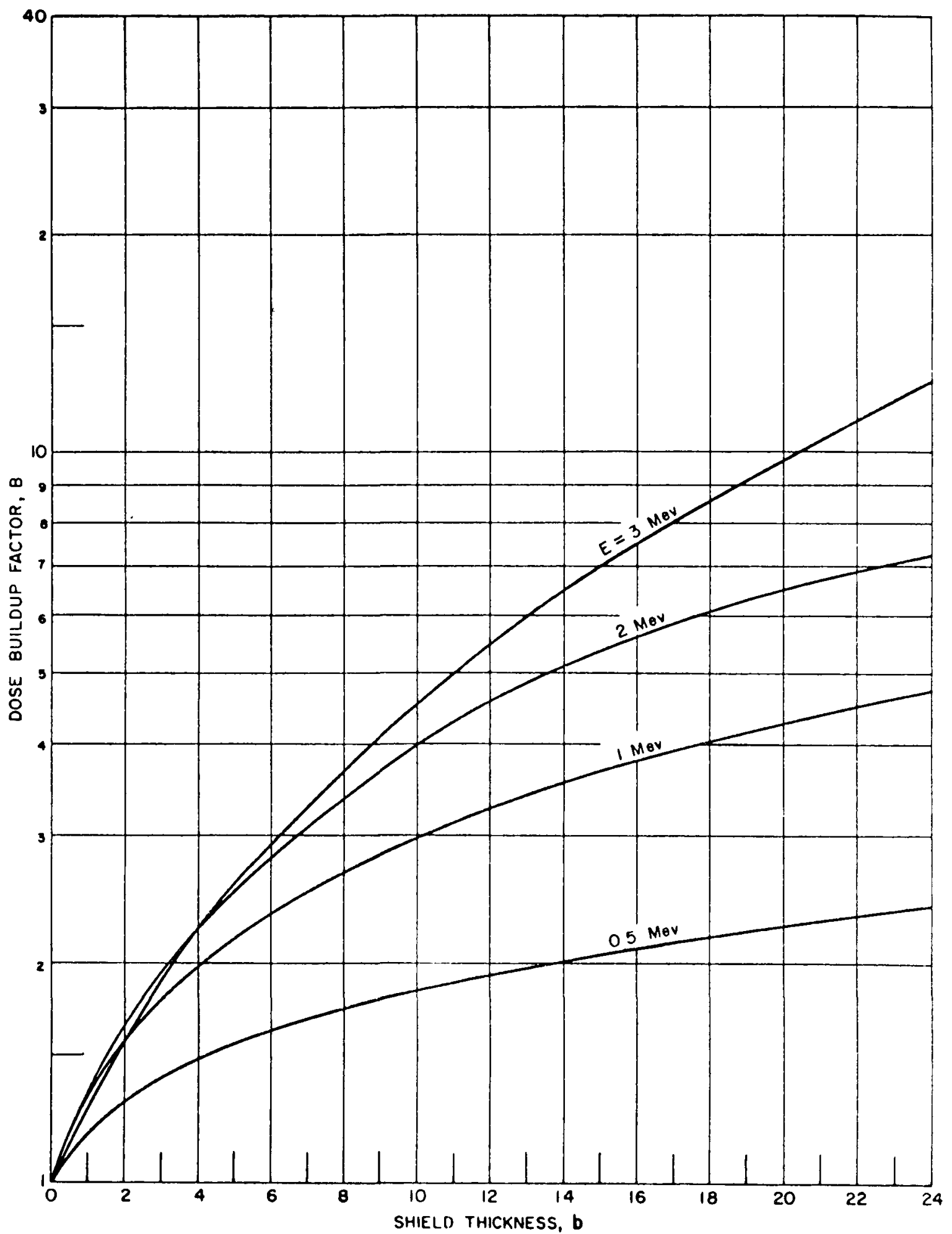

FIG. 8-7a. DOSE BUILOUP FACTOR FOR URANIUM 


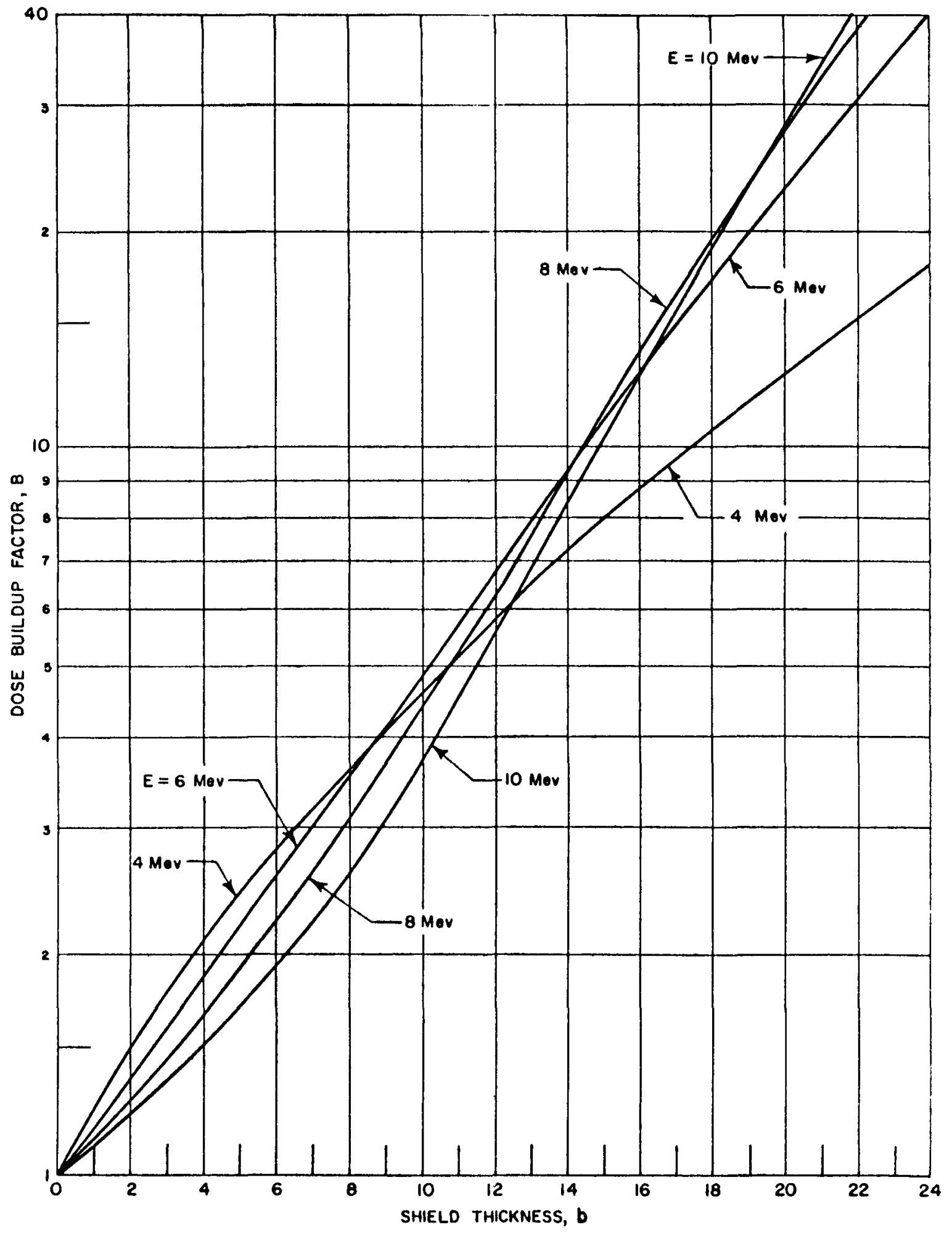

FIG. B-TD. DOSE BUILOUP FACTOR FOR URANIUM 